U.S. Department of the Interior

U.S. Geological Survey
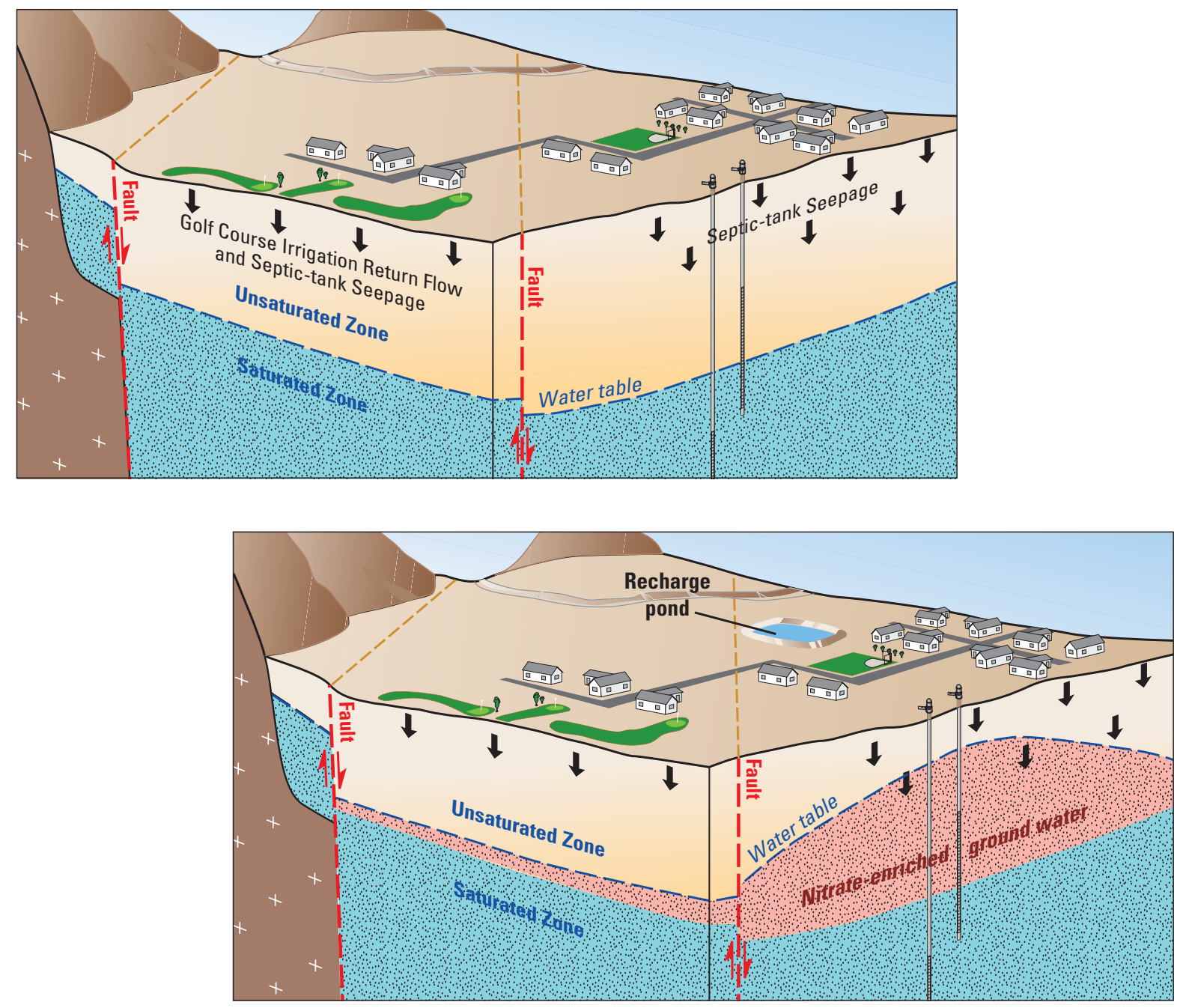

\title{
EVALUATION OF THE SOURCE AND TRANSPORT OF HIGH NITRATE CONCENTRATIONS IN GROUND WATER, WARREN SUBBASIN, CALIFORNIA
}

Prepared in cooperation with HI-DESERT WATER DISTRICT

Water-Resources Investigations Report

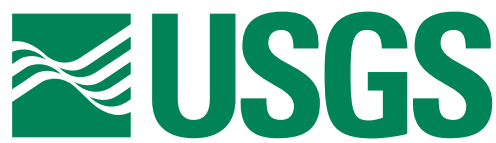
03-4009 


\section{Evaluation of the Source and Transport of High Nitrate Concentrations in Ground Water, Warren Subbasin, California}

By Tracy Nishikawa, Jill N. Densmore, Peter Martin and Jonathan Matti

U.S. GEOLOGICAL SURVEY

Water-Resources Investigations Report 03-4009

Version 1.1, September 2018

Prepared in cooperation with the

HI-DESERT WATER DISTRICT and the

MOJAVE WATER AGENCY

$\overline{1}$
0
0

Sacramento, California

2003 


\title{
U.S. DEPARTMENT OF THE INTERIOR
}

GALE A. NORTON, Secretary

\section{U.S. GEOLOGICAL SURVEY}

\author{
Charles G. Groat, Director
}

Any use of trade, product, or firm names in this publication is for descriptive purposes only and does not imply endorsement by the U.S. Government.

For additional information write to:

District Chief

U.S. Geological Survey

Placer Hall-Suite2012

$6000 \mathrm{~J}$ Street

Sacramento, CA 95819-6129

http://ca.water.usgs.gov
Copies of this report can be purchased from:

U.S. Geological Survey

Information Services

Building 810

Box 25286, Federal Center

Denver, CO 80225-0286 


\section{CONTENTS}

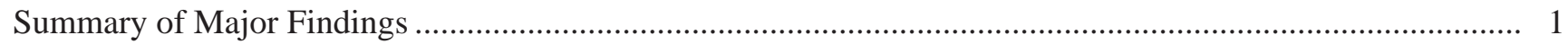

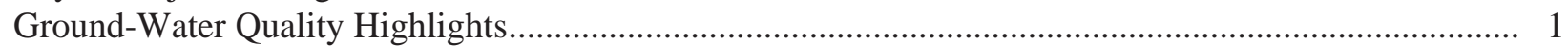

Ground-Water Flow and Solute-Transport Model Highlights ...................................................... 1

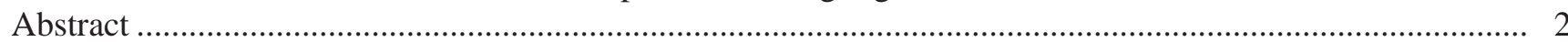

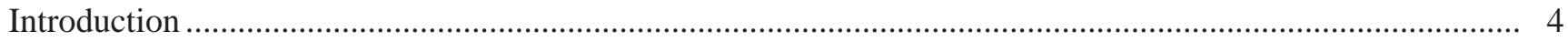

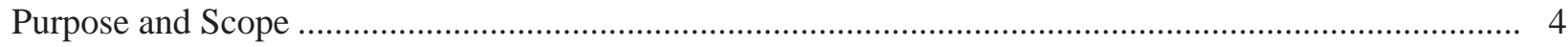

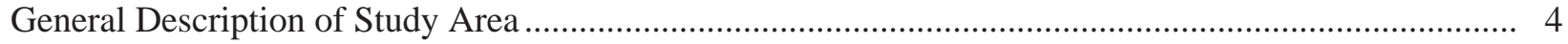

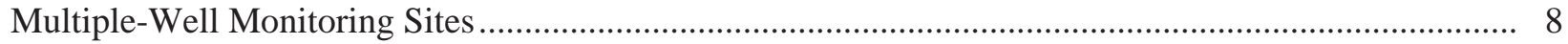

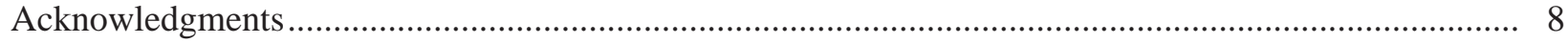

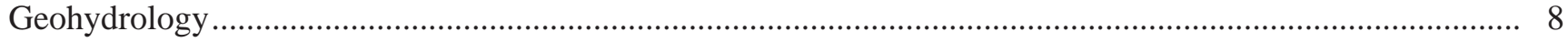

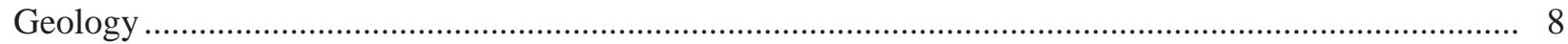

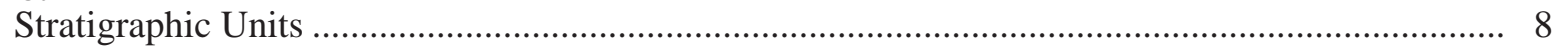

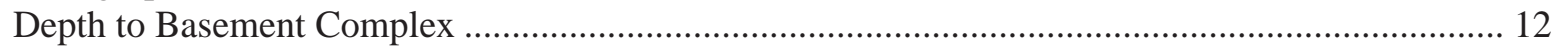

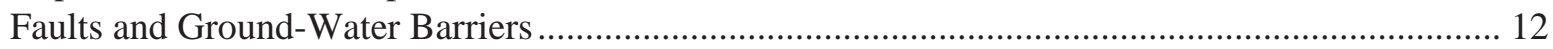

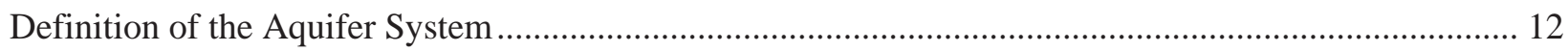

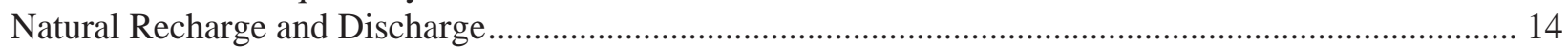

Ground-Water Development and Artificial Recharge .................................................................... 14

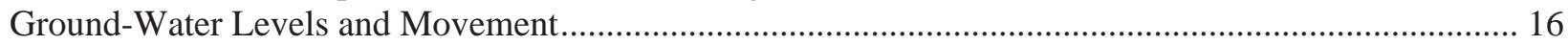

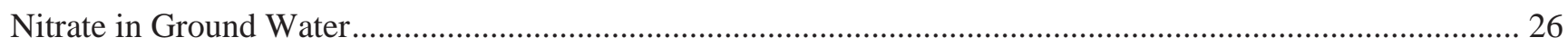

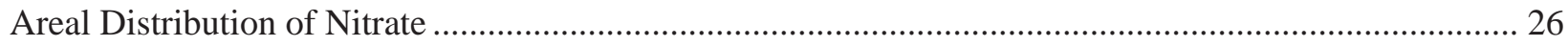

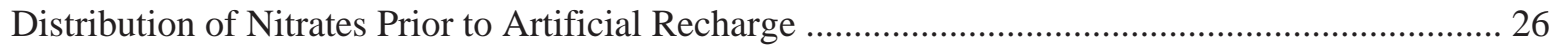

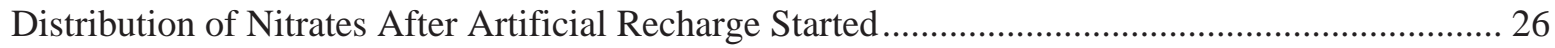

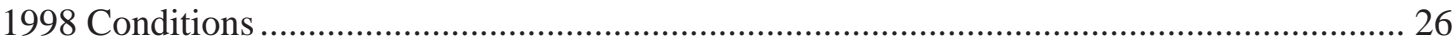

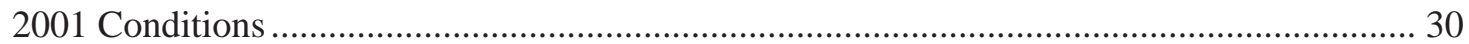

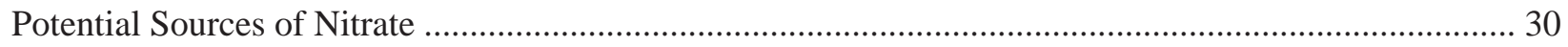

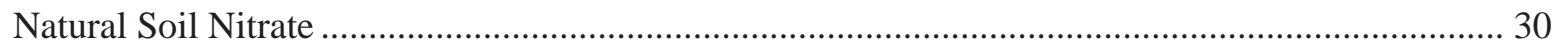

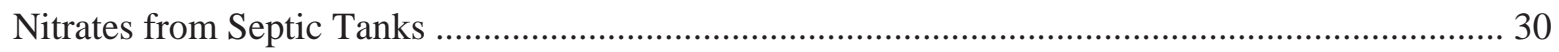

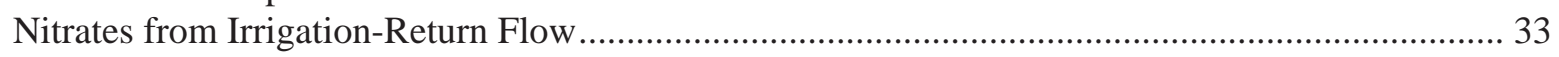

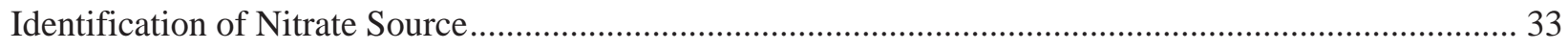

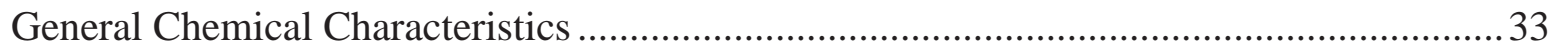

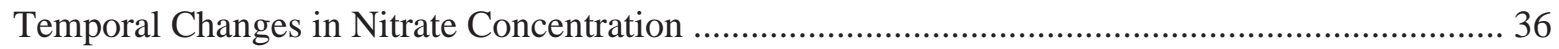

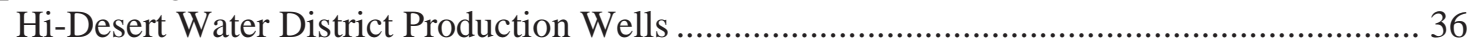

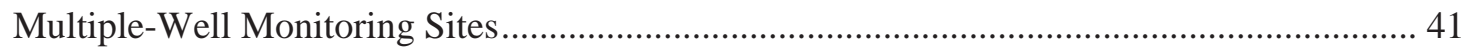

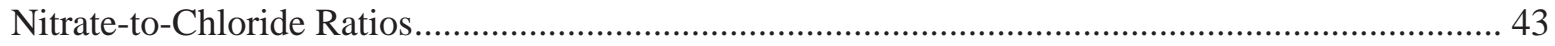

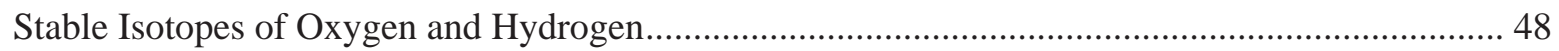

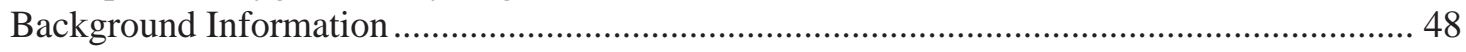

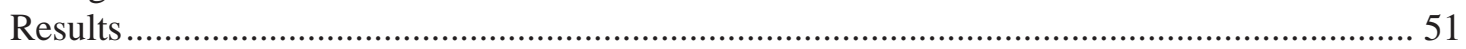

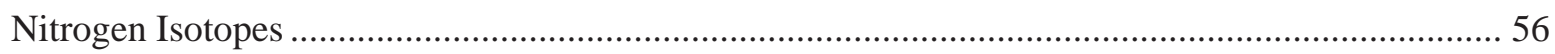

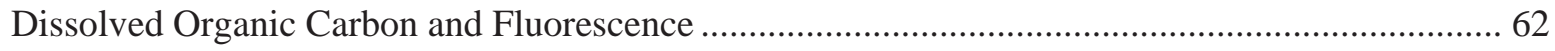

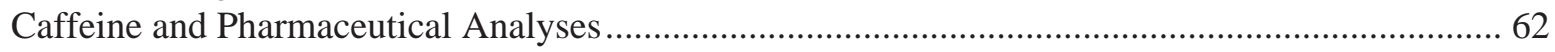

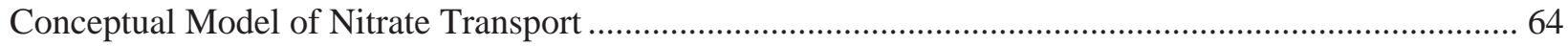

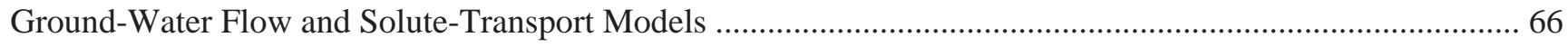

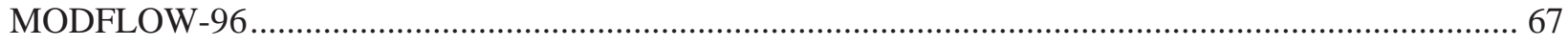

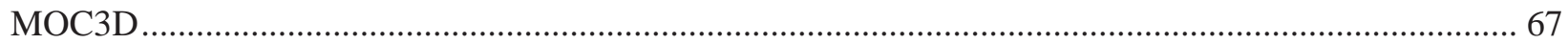




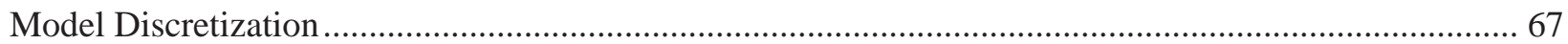

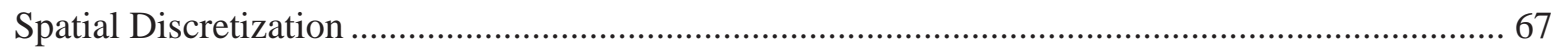

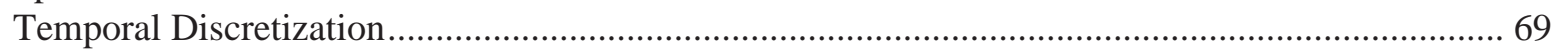

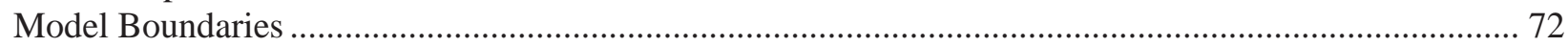

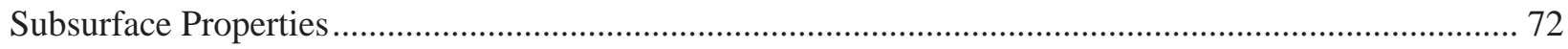

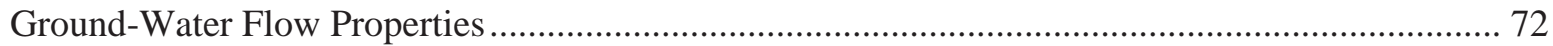

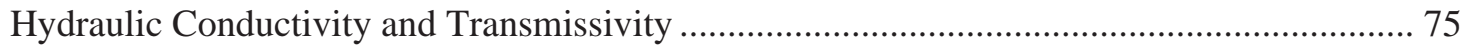

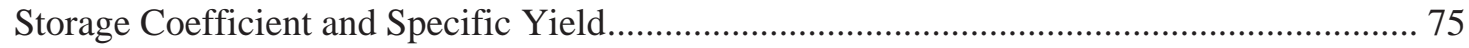

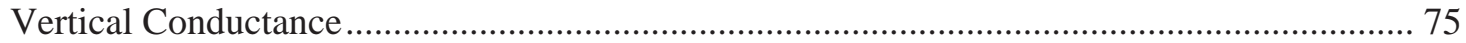

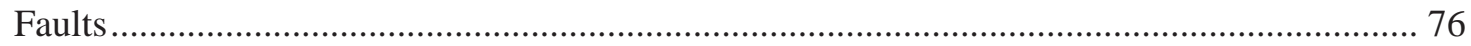

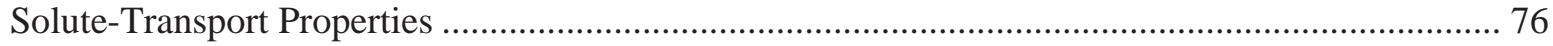

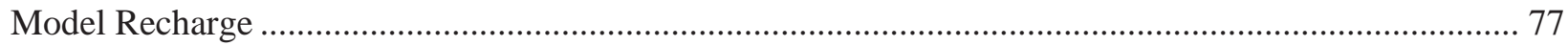

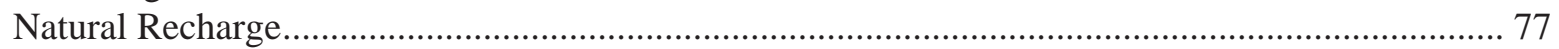

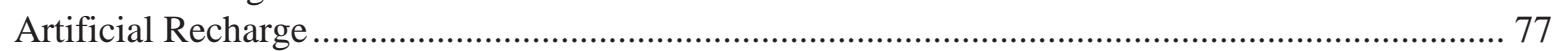

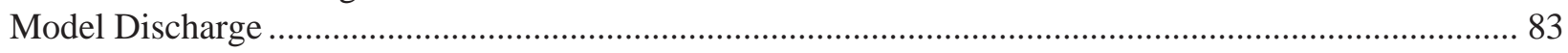

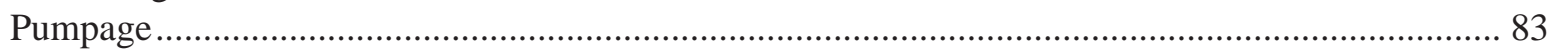

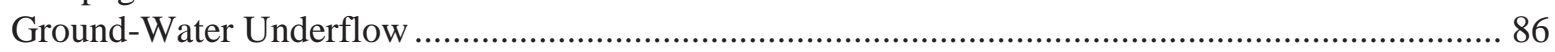

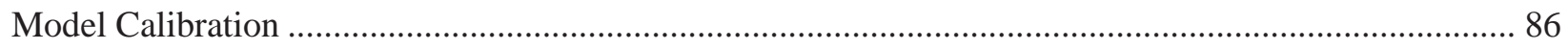

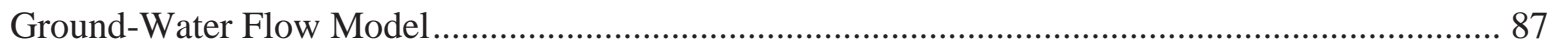

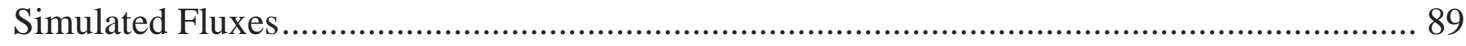

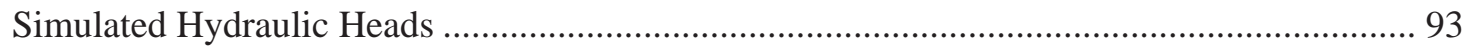

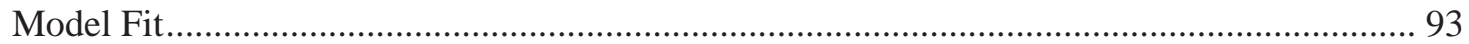

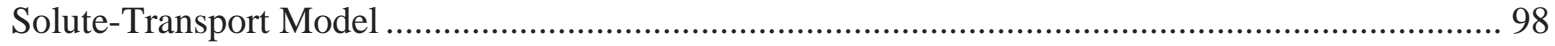

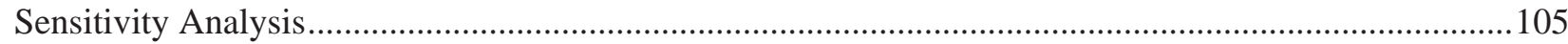

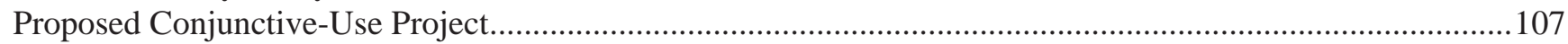

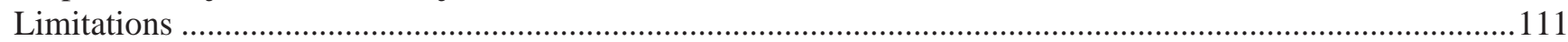

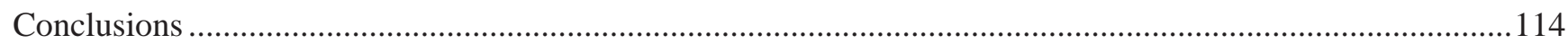

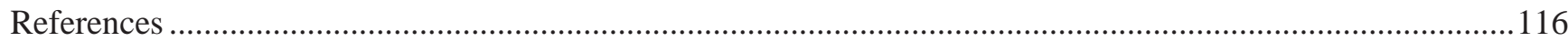




\section{FIGURES}

Figure 1. Map showing location of study area, Warren subbasin, San Bernardino County, California .......... 5

Figure 2. Map showing land use for 1952-53, 1965, 1977, and 1993 in Warren ground-water basin, San Bernardino County, California.

Figure 3 Graph showing total residential, multi-family, commercial, and irrigated recreational field acreage for 1952-53, 1965, 1977, and 1993 in Warren ground-water basin, San Bernardino County, California.

Figure 4. Map showing generalized surficial geology, major faults, location of wells, and soil-sampling sites for the Warren subbasin, California.....

Figure 5. Map showing depth to basement complex based on gravity data, Warren subbasin, California ...... 13

Figure 6 Graph showing geologic section along section line A-A' (see fig. 1) showing locations and depths of production and monitoring wells; locations of the recharge sites; and the upper, middle, lower, and deep aquifer systems of the Warren ground-water basin, San Bernardino County, California

Figure 7. Graph showing total annual pumpage, 1956-2001, Warren ground-water basin, San Bernardino

County, California

Figure 8. Graph showing total monthly artificial recharge, 1995-2001, Warren ground-water basin,

San Bernardino County, California.

Figure 9. Map showing water-level maps for (A) 1958, (B) 1969, (C) 1994, and (D) 1998, Warren ground-water basin, San Bernardino County, California.

Figure 10. Water-level hydrographs for wells (A) 1N/5E-36K1 (HDWD-1) and 36K2 (HDWD-1) in the midwest hydrogeologic unit and (B) 1N/5E-36H2 (18E) and 36K3 (14E) in the mideast hydrogeologic unit, Warren ground-water basin, San Bernardino County, California

Figure 11. Map showing areal distribution of nitrate prior to artificial recharge program during

(A) September 1991 to January 1995, (B) 1998, and (C) 2001, Warren ground-water basin, San Bernardino County, California.

Figure 12. Graph showing comparison of total nitrogen in whole soils with nitrate concentrations in soil leachate, Warren ground-water basin, San Bernardino County, California

Figure 13 Graph showing water-quality diagrams of selected ground-water samples for the (A) west,

(B) midwest, (C) mideast, and (D) east and northeast hydrogeologic units, Warren ground-water

basin, San Bernardino County, California

Figure 14. Graph showing nitrate concentrations in samples from selected Hi-Desert Water District production wells in the (A) west, (B) midwest, (C) mideast, and (D) northeast hydrogeologic units, Warren ground-water basin, San Bernardino County, California

Figure 15. Graph showing changes in water-surface altitude and nitrate concentrations in (A) 1N/5E-36G1-4 (YV1) and (B) 1N/5E-36M1-3 (YV2), Warren ground-water basin, San Bernardino County, California

Figure 16 Graph showing relation between nitrate-to-chloride ratio and nitrate in ground-water samples from wells in the (A) west, (B) midwest, (C) mideast, and (D) northeast and east hydrogeologic units, Warren ground-water basin, San Bernardino County, California.....

Figure 17. Graph showing stable isotopes from ground-water samples collected from selected wells in the (A) midwest and (B) mideast hydrogeologic units, Warren ground-water basin, San Bernardino County, California.

Figure 18. Graph showing relation between delta oxygen-18 and nitrate from ground-water samples from multiple-well monitoring sites: (A) 1N/5E-36G1-4 (YV1) and (B) 1N/5E-36M1-3 (YV2), Warren ground-water basin, San Bernardino County, California. 
Figure 19. Graph showing nitrogen isotope concentrations from ground-water samples from selected wells in the (A) west, (B) midwest, (C) and mideast and northeast hydrogeologic units, Warren ground-water basin, San Bernardino County, California and septage samples from Victorville, California .

Figure 20. Graph showing relation between fluorescence and dissolved organic carbon in samples of:

(A) septage and septic-tank water at Victorville, California (Number at data point indicates depth at which sample was collected) and (B) ground water at Warren ground-water basin, San

Bernardino County, California

Figure 21 Conceptual model of septage entrainment: (A) downward migration of septage in unsaturated zone prior to artificial-recharge operations and (B) water-level rise entraining septage, Warren ground-water basin, San Bernardino County, California.

Figure 22. Map showing model grid for the ground-water flow and solute-transport model of the Warren ground-water basin, San Bernardino County, California, showing active and inactive cells, modeled faults, natural recharge cells, artificial recharge cells, and general-head boundary .....

Figure 23. Graph showing vertical discretization along section line A-A' (see fig. 1) of the ground-water flow and solute-transport model of the Warren ground-water basin, San Bernardino County, California

Figure 24. Graph showing simulated hydraulic head using no stresses for wells 1 S/5E-3D1 (8W),

1N/5E-36K1 (HDWD-1), and 1N/5E-36H2 (18E) for 10,000 years, Warren ground-water basin,

San Bernardino County, California

Figure 25. Graph showing time-varying mass-balance errors by stress period for the ground-water flow and solute-transport models, Warren ground-water basin, San Bernardino County, California ....... 73

Figure 26. Map showing areal distribution of irrigation return flow and septage for: (A) 1956-64, (B) 1965-76, (C) 1977-1989, (D) 1990-94, and (E) 1995-2001, Warren ground-water basin, San Bernardino County, California.

Figure 27. Map showing water-level change between 1994 and 1998, Warren ground-water basin, San Bernardino County, California.

Figure 28. Map showing areal distribution of entrained unsaturated-zone water for 1995-97, Warren ground-water basin, San Bernardino County, California.

Figure 29. Map showing specific yield of model layer 1 for drawdown (pre-1995) and recovery (post-1995) conditions, Warren ground-water basin, San Bernardino County, California

Figure 30. Graph showing measured water levels and simulated hydraulic heads for (A) 1S/5E-3D1 (8W),

(B) 1N/5E-36K1 (HDWD-1) and 36K2 (9E), (C) 1N/5E-36H2 (18E), and (D) 1N/6E-31C1 (5E),

Warren ground-water basin, San Bernardino County, California.....

Figure 31. Graph showing simulated hydraulic head and measured water levels for: (A) 1958, (B) 1994, (C) 1998, and (D) 2000, Warren ground-water basin, San Bernardino County, California 96

Figure 32. Map showing nitrate concentrations measured in July and August 2001 and contours of simulated model-layer 1 nitrate concentrations for July 2001 assuming a nitrate concentration for septage and entrained unsaturated zone water of (A) $220 \mathrm{mg} / \mathrm{L}$ and (B) $350 \mathrm{mg} / \mathrm{L}$, Warren ground-water basin, San Bernardino County, California.

Figure 33. Graph showing simulated and measured nitrate concentrations assuming the nitrate concentrations of the septage were 220 and $350 \mathrm{mg} / \mathrm{L}$ for (A) 1S/5E-3D1 (8W), (B) 1N/5E-36K2 (9E),

(C) 1N/5E-36M5 (16E), (D) 1N/5E-36H2 (18E), (E) 1N/5E-36K3 (14E), and

(F) 1N/6E-31C1 (5E), Warren ground-water basin, San Bernardino County, California

Figure 34. Graph showing simulated nitrate concentrations from the calibrated transient-state solute-transport model showing sensitivity to dispersivity: (A) 1S/5E-3D1 (8W), (B) 1N/5E-36K2 (9E), (C) 1N/5E-36M5 (16E), and (D) 1N/5E-36H2 (18E), Warren ground-water basin, San Bernardino County, California. 
Figure 35. Map showing contours of simulated change in model-layer 1 hydraulic head between December 2001 and December 2011 for the proposed conjunctive-use project, Warren ground-water basin, San Bernardino County, California

Figure 36. Map showing contours of (A) change in simulated nitrate concentrations between December 2001 and December 2011 conditions and (B) simulated nitrate concentrations for December 2011 in model-layer 1 for the proposed conjunctive-use project, Warren ground-water basin, San Bernardino County, California. 


\section{TABLES}

Table 1. Well-construction data for wells in the Warren ground-water basin, California

Table 2. Potential quantity of septic-tank seepage and infiltrated irrigation-return flow for different land-use categories in Warren ground-water basin, California

Table 3. Soil nitrate data for soil samples from Warren ground-water basin, California

Table 4. Nitrate concentrations, in milligrams per liter as NO3 (nitrate), in ground water from wells in Warren ground-water basin, 1964-2001

Table 5. Analyses of stable-isotopes of deuterium and oxygen, tritium, and carbon-14 analyses from selected wells in the Warren ground-water basin, California

Table 6. Analyses of nitrate as nitrate, nitrogen isotope, dissolved organic carbon and fluorescence from selected wells in Warren ground-water basin and lysimeters in Victorville, California

Table 7. Initial and final ground-water flow parameter estimates

Table 8A. Simulated recharge and discharge for the west, the midwest, the mideast, the northeast, and the east hydrogeologic units, Warren subbasin, California

Table 8B. Simulated flow rates between hydrogeologic units, for predevelopment, 1994, 1995, and 2001 ..... 92

Table 9. The variation in root-mean-square error (RMSE) between simulated year-2000 hydraulic heads and measured year-2000 water levels for each sensitivity analysis by hydrogeologic unit [west, midwest, mideast, and total east (east and northeast)] and the total RMSE for the entire model domain 


\section{CONVERSION FACTORS, VERTICAL DATUM, ABBREVIATIONS AND ACRONYMS}

CONVERSION FACTORS

\begin{tabular}{|c|c|c|}
\hline Multiply & By & To obtain \\
\hline \multicolumn{3}{|c|}{ Length } \\
\hline inch (in.) & 25.4 & millimeter \\
\hline foot $(\mathrm{ft})$ & 0.3048 & meter \\
\hline foot per foot $(\mathrm{ft} / \mathrm{ft})$ & 1.0000 & meter per meter \\
\hline mile (mi) & 1.609 & kilometer \\
\hline \multicolumn{3}{|c|}{ Area } \\
\hline acre & 4,047 & square meter \\
\hline acre & 0.4047 & hectare \\
\hline square foot $\left(\mathrm{ft}^{2}\right)$ & 0.09290 & square meter \\
\hline square mile $\left(\mathrm{mi}^{2}\right)$ & 2.590 & square kilometer \\
\hline \multicolumn{3}{|c|}{ Volume } \\
\hline gallon (gal) & 0.003785 & cubic meter \\
\hline cubic foot $\left(\mathrm{ft}^{3}\right)$ & 0.02832 & cubic meter \\
\hline acre-foot (acre-ft) & 1,233 & cubic meter \\
\hline \multicolumn{3}{|c|}{ Flow rate } \\
\hline acre-foot per day (acre-ft/d) & 0.01427 & cubic meter per second \\
\hline acre-foot per month (acre-ft/mo) & 1,233 & cubic meter per month \\
\hline acre-foot per year (acre-ft/yr) & 1,233 & cubic meter per year \\
\hline foot per day $(\mathrm{ft} / \mathrm{d})$ & 0.3048 & meter per day \\
\hline foot per year $(\mathrm{ft} / \mathrm{yr})$ & 0.3048 & meter per year \\
\hline gallon per minute (gal/min) & 0.06309 & liter per second \\
\hline gallon per day $(\mathrm{gal} / \mathrm{d})$ & 0.003785 & cubic meter per day \\
\hline gallon per day per acre (gal/d/acre) & 0.009354 & cubic meter per day per hectare \\
\hline inch per year (in./yr) & 25.4 & millimeter per year \\
\hline \multicolumn{3}{|c|}{ Radioactivity } \\
\hline picocurie per liter $(\mathrm{pCi} / \mathrm{L})$ & 0.037 & becquerel per liter \\
\hline \multicolumn{3}{|c|}{ Hydraulic conductivity } \\
\hline foot per day (ft/d) & 0.3048 & meter per day \\
\hline \multicolumn{3}{|c|}{ Transmissivity* } \\
\hline foot squared per day $\left(\mathrm{ft}^{2} / \mathrm{d}\right)$ & 0.09290 & meter squared per day \\
\hline \multicolumn{3}{|c|}{ Leakance } \\
\hline foot per day per foot $[(\mathrm{ft} / \mathrm{d}) / \mathrm{ft}]$ & 1 & meter per day per meter \\
\hline
\end{tabular}

Temperature in degrees Fahrenheit $\left({ }^{\circ} \mathrm{F}\right)$ may be converted to degrees Celsius $\left({ }^{\circ} \mathrm{C}\right)$ as follows:

${ }^{\circ} \mathrm{C}=\left({ }^{\circ} \mathrm{F}-32\right) / 1.8$

VERTICAL DATUM

Sea level: In this report, "sea level" refers to the National Geodetic Vertical Datum of 1929 (NGVD of 1929) - a geodetic datum derived from a general adjustment of the first-order level nets of both the United States and Canada, formerly called Sea Level Datum of 1929.

Altitude, as used in this report, refers to distance above or below sea level. 
*Transmissivity: The standard unit for transmissivity is cubic foot per day per square foot times foot of aquifer thickness $\left[\left(\mathrm{ft}^{3} / \mathrm{d}\right) / \mathrm{ft}^{2}\right] \mathrm{ft}$. In this report, the mathematically reduced form, foot squared per day $\left(\mathrm{ft}^{2} / \mathrm{d}\right)$, is used for convenience.

Concentrations of chemical constituents in water are given either in milligrams per liter (mg/L) or micrograms per liter $(\mu \mathrm{g} / \mathrm{L})$.

NOTE TO USGS USERS: Use of hectare (ha) as an alternative name for square hectometer $\left(\mathrm{hm}^{2}\right)$ is restricted to the measurement of small land or water areas. Use of liter (L) as a special name for cubic decimeter $\left(\mathrm{dm}^{3}\right)$ is restricted to the measurement of liquids and gases. No prefix other than milli should be used with liter. Metric ton ( $\mathrm{t}$ ) as a name for megagram $(\mathrm{Mg}$ ) should be restricted to commercial usage, and no prefixes should be used with it.

\section{Abbreviations and Acronyms}

$\alpha$

dispersivity

$\mathrm{Ca}$

calcium

$\mathrm{Cl}$

chloride

$\mathrm{Cu}_{2} \mathrm{O}$

copper oxide

$\delta$

delta

$\delta^{15} \mathrm{~N}$

nitrogen isotope

D

deuterium $\left({ }^{2}\right.$ hydrogen $)$

DEM

Digital Elevation Model

DOC dissolved organic carbon

eqn equation

EROS Earth Resources Observation System

GHB general-head boundary

GIS Geographic Information Systems

$\mathrm{gm} / \mathrm{cm}^{3} \quad$ gram per cubic centimeter

${ }^{1} \mathrm{H} \quad$ hydrogen

$\mathrm{HCO}_{3} \quad$ (calcium $(\mathrm{Ca}) /$ sodium (Na)-)bicarbonate

HDWD Hi-Desert Water District

HFB Horizontal-Flow-Barrier Package

K hydraulic conductivity

$\mathrm{K}_{\mathrm{z}} \quad$ vertical hydraulic conductivity

$\mathrm{kg} \quad$ kilogram

MCL maximum contaminant level

$\mathrm{mg} / \mathrm{kg} \quad$ milligrams per kilogram

$\mathrm{mg} / \mathrm{L} \quad$ milligrams per liter

MOC3D finite-difference model that simulates three-

dimensional solute transport

in flowing ground water 
MODFLOW-96 finite-difference model that simulates ground-water flow in a three-dimensional heterogeneous and anisotropic medium

$\begin{array}{ll}\text { MWA } & \text { Mojave Water Agency } \\ \mathrm{N} & \text { nitrogen } \\ { }^{14} \mathrm{~N} & \text { nitrogen-14 } \\ { }^{15} \mathrm{~N} & \text { nitrogen-15 } \\ \mathrm{Na} & \text { sodium } \\ \mathrm{NO}_{3} & \text { nitrate } \\ \mathrm{NO}_{3}-\mathrm{N} & \text { nitrate as nitrogen } \\ \mathrm{NWIS}^{16} \mathrm{O} & \text { National Water Information System } \\ { }^{18} \mathrm{O} & \text { oxygen-16 } \\ \text { per mil } & \text { oxygen-18 } \\ \mathrm{PVC} & \text { parts per thousand } \\ \mathrm{RMSE} & \text { polyvinyl chloride } \\ \mathrm{SWP} & \text { root-mean-squared error } \\ \mathrm{S}_{\mathrm{S}} & \text { California State Water Project } \\ \mathrm{S}_{\mathrm{y}} & \text { specific storage } \\ \text { USEPA } & \text { specific yield } \\ \text { USGS } & \text { U.S. Environmental Projection Agency } \\ \text { VSMOW } & \text { Vienna Standard Mean Ocean Water }\end{array}$




\section{WELL-NUMBERING SYSTEM}

Wells are identified and numbered according to their location in the rectangular system for the subdivision of public lands. Identification consists of the township number, north or south; the range number, east or west; and the section number. Each section is divided into sixteen 40-acre tracts lettered consecutively (except I and O), beginning with "A" in the northeast corner of the section and progressing in a sinusoidal manner to " $\mathrm{R}$ " in the southeast corner. Within the 40-acre tract, wells are sequentially numbered in the order they are inventoried. The final letter refers to the base line and meridian. In California, there are three base lines and meridians; Humboldt (H), Mount Diablo (M), and San Bernardino (S). All wells in the study area are referenced to the San Bernardino base line and meridian (S) Well numbers consist of 15 characters and follow the format 001N005E36K001S. In this report, well numbers are abbreviated and written 1N/5E-36K1. Wells in the same township and range are referred to only by their section designation, $36 \mathrm{~K} 1$. The following diagram shows how the number for well $1 \mathrm{~N} / 5 \mathrm{E}-36 \mathrm{~K} 1$ is derived.

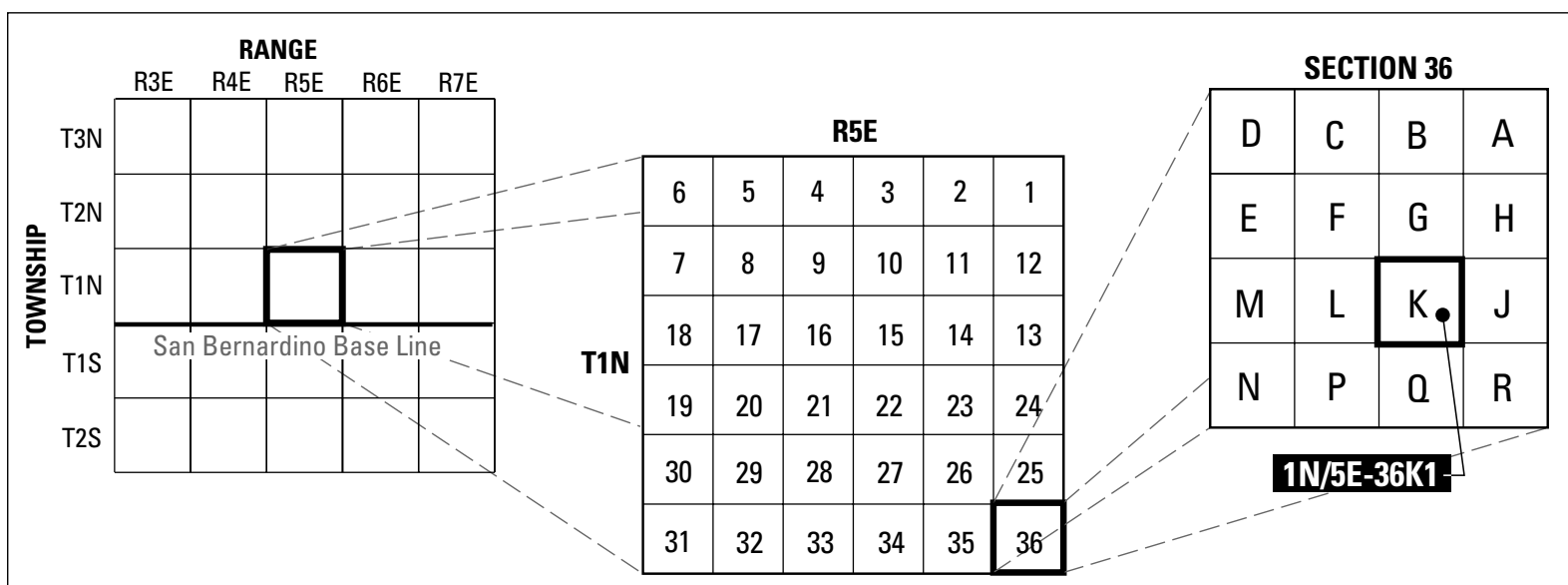

Well-numbering diagram (Note: maps in this report use abbreviated well numbers such as "36K1") 


\title{
Evaluation of the Source and Transport of High Nitrate Concentrations in Ground Water, Warren Subbasin, California
}

\author{
By Tracy Nishikawa, Jill N. Densmore, Peter Martin, and Jonathan Matti
}

\section{SUMMARY OF MAJOR FINDINGS}

\section{Ground-Water Quality Highlights}

From early 1995 through 2001, nitrate $\left(\mathrm{NO}_{3}\right)$ concentrations in ground water in the Warren subbasin, California, increased from a background concentration of 10 milligrams per liter $(\mathrm{mg} / \mathrm{L})$ to more than the U.S. Environmental Protection Agency (USEPA) waterquality maximum contaminant level of $44 \mathrm{mg} / \mathrm{L}$ (10 $\mathrm{mg} / \mathrm{L}$ as nitrogen). This increase coincided with an artificial ground-water recharge program implemented by the local water district, Hi-Desert Water District (HDWD), to reverse ground-water level declines of as much as $300 \mathrm{ft}$. Major findings on ground-water quality from this study are the following:

- $\quad$ Septage from septic tanks was the primary source of $\mathrm{NO}_{3}$ to the ground-water system.

- $\quad$ Rising ground-water levels, resulting from the artificial-recharge program, entrained high- $\mathrm{NO}_{3}$ septage stored in the unsaturated zone.

- The potential for ground-water contamination should be evaluated before beginning an artificialrecharge program in an area that uses septic tanks.

\section{Ground-Water Flow and Solute-Transport Model Highlights}

In order to better understand the dynamics of ground-water flow and solute transport in the Warren subbasin, ground-water flow and solute-transport models were developed. Major findings from the model development and implementation are the following:

- Based on geophysical data, the effective area of the ground-water basin is much smaller than the subbasin (5.5 versus 19 square miles).

- The extensive faulting of the subbasin effectively compartmentalizes the ground-water flow and solute-transport systems into five hydrogeologic units (west, midwest, mideast, east, and northeast).

- The source of natural recharge is runoff from the mountains on the north side of the subbasin and equals 83 acre-feet per year (acre-ft/yr).

- $\quad$ The results from the ground-water flow and solute-transport models were in good agreement with measured data indicating that the models could be used to determine the potential effects of water-management strategies.

- The model results indicate that almost all of the artificially recharged water in the midwest and the mideast hydrogeologic units remained in those units.

- The model results indicate that the artificialrecharge program had a minor effect on the measured $\mathrm{NO}_{3}$ concentrations in the east and northeast hydrogeologic units.

- The models were used to determine the effect of recharging 3,300 acre-ft/yr at proposed site 3, recharging a total of 3,800 acre-ft/yr at existing sites 6 and 7, and increasing pumping from three existing wells (HDWD production wells 12E, $16 \mathrm{E}$, and 17E) used to remove $\mathrm{NO}_{3}$. 
- $\quad$ Flow model results indicate that water levels may increase $75 \mathrm{ft}$ in the west hydrogeologic unit, decrease as much as $85 \mathrm{ft}$ in the midwest hydrogeologic unit, and increase as much as $190 \mathrm{ft}$ in the mideast hydrogeologic unit.

- Solute-transport model results indicate an increase in $\mathrm{NO}_{3}$ concentrations of about $30-35 \mathrm{mg} / \mathrm{L}$ in the west hydrogeologic unit, a decrease of about 15 $\mathrm{mg} / \mathrm{L}$ in the midwest hydrogeologic unit, and increases of as much as $50 \mathrm{mg} / \mathrm{L}$ in parts of the mideast and the east hydrogeologic units. The simulated increase in the mideast and the east hydrogeologic units was related to commercial land use.

\section{ABSTRACT}

Ground water historically has been the sole source of water supply for the Town of Yucca Valley in the Warren subbasin of the Morongo ground-water basin, California. An imbalance between ground-water recharge and pumpage caused ground-water levels in the subbasin to decline by as much as 300 feet from the late 1940s through 1994. In response, the local water district, Hi-Desert Water District, instituted an artificial recharge program in February 1995 using imported surface water to replenish the ground water. The artificial recharge program resulted in water-level recoveries of as much as 250 feet in the vicinity of the recharge ponds between February 1995 and December 2001; however, nitrate concentrations in some wells also increased from a background concentration of 10 milligrams per liter to more than the U.S. Environmental Protection Agency (USEPA) maximum contaminant level (MCL) of 44 milligrams per liter (10 milligrams per liter as nitrogen).

The objectives of this study were to: (1) evaluate the sources of the high-nitrate concentrations that occurred after the start of the artificial-recharge program, (2) develop a groundwater flow and solute-transport model to better understand the source and transport of nitrates in the aquifer system, and (3) utilize the calibrated models to evaluate the possible effect of a proposed conjunctive-use project. These objectives were accomplished by collecting waterlevel and water-quality data for the subbasin and assessing changes that have occurred since artificial recharge began. Collected data were used to calibrate the ground-water flow and solutetransport models.

Data collected for this study indicate that the areal extent of the water-bearing deposits is much smaller (about 5.5 square miles versus 19 square miles) than that of the subbasin. These waterbearing deposits are referred to in this report as the Warren ground-water basin. Faults separate the ground-water basin into five hydrogeologic units: the west, the midwest, the mideast, the east and the northeast hydrogeologic units.

Water-quality analyses indicate that septage from septic tanks is the primary source of the highnitrate concentrations measured in the Warren ground-water basin. Water-quality and stableisotope data, collected after the start of the artificial recharge program, indicate that mixing occurs between imported water and native ground water, with the highest recorded nitrate concentrations in the midwest and the mideast hydrogeologic units. In general, the timing of the increase in measured nitrate concentrations in the midwest hydrogeologic unit is directly related to the distance of the monitoring well from a recharge site, indicating that the increase in nitrate concentrations is related to the artificial recharge program. Nitrate-to-chloride and nitrogen-isotope data indicate that septage is the source of the measured increase in nitrate concentrations in the midwest and the mideast hydrogeologic units. Samples from four wells in the Warren groundwater basin were analyzed for caffeine and selected human pharmaceutical products; these analyses suggest that septage is reaching the water table. 
There are two possible conceptual models that explain how high-nitrate septage reaches the water table: (1) the continued downward migration of septage through the unsaturated zone to the water table and (2) rising water levels, a result of the artificial recharge program, entraining septage in the unsaturated zone. The observations that nitrate concentrations increase in ground-water samples from wells soon after the start of the artificial recharge program in 1995 and that the largest increase in nitrate concentrations occur in the midwest and mideast hydrogeologic units where the largest increase in water levels occur indicate the validity of the second conceptual model (rising water levels). The potential nitrate concentration resulting from a water-level rise in the midwest and mideast hydrogeologic units was estimated using a simple mixing-cell model. The estimated value is within the range of concentrations measured in samples from wells, further indicating the validity of the second conceptual model.

A ground-water flow model and a solutetransport model were developed for the Warren ground-water basin for the period 1956-2001. MODFLOW-96 was used for the ground-water flow model and MOC3D was used for the solutetransport model. The model cell size is about 500 feet by 500 feet and the models were discretized vertically into three layers. The models were calibrated using a trial-and-error approach using water-level and nitrate-concentration data collected between 1956 and 2001. In order to better match the measured data, low fault hydraulic characteristic values were required, thereby compartmentalizing the ground-water basin. In addition, it was necessary to parameterize the specific yield distribution for the top model layer where unconfined ground-water conditions occur into three homogeneous zones. Separate sets of specific- yield values were needed to simulate the drawdown and subsequent water-level recovery. In addition, the calibrated natural recharge was about 83 acre-feet per year. The entrainment of unsaturated-zone septage was simulated as recharge having an associated nitrate concentration. The volume of recharge was a function of the measured water-level rise between 1994 and 98 and the moisture content of the unsaturated zone. The nitrate concentration of the recharge water was a weighted function of the assumed nitrate concentration in the infiltrating water associated with the overlying land use. The simulated hydraulic head and nitrate concentration results were in good agreement with the measured data indicating that the mechanism for the increase in nitrate concentrations was rising water levels entraining high-nitrate septage in the unsaturated zone.

The calibrated models were used to simulate the possible effects of a planned conjunctive-use project in the western part of the ground-water basin. The simulated project included the addition of a new recharge pond and a new extraction well. In addition, recharge at two existing recharge ponds was increased, and three existing production wells were pumped, treated in a nitrate-removal facility, and used for water supply. The simulated hydraulic heads increased in the west, the mideast, and parts of the east hydrogeologic units; however, the simulated hydraulic heads decreased in the midwest and northeast hydrogeologic units. The simulated nitrate concentrations increased to above the MCL of 44 milligrams per liter (10 milligrams per liter as nitrogen) in parts of the west as a result of the increase in simulated hydraulic head. The simulated nitrate concentrations decreased in part of the midwest hydrogeologic unit as a result of the artificial recharge and pumping from the nitrate-removal wells. The simulated nitrate concentrations increased to above the MCL of 44 milligrams per liter in part of the mideast and parts of the east hydrogeologic units beneath commercial land-use areas. 


\section{INTRODUCTION}

Ground water historically has been the sole source of water supply for the Town of Yucca Valley in the Warren subbasin of the Morongo ground-water basin (fig. 1). An imbalance between ground-water recharge and pumpage caused ground-water levels in the subbasin to decline by as much as $300 \mathrm{ft}$ from the late 1940s through 1994 (Huff and others, 2003). To reverse this water-level decline and to provide for future water supply, an artificial recharge program was initiated in February 1995 by the local water district, Hi-Desert Water District (HDWD). Imported water from the California State Water Project (SWP) is used to recharge the ground-water subbasin through surface spreading. As a result of the artificial recharge, water levels have recovered by as much as $250 \mathrm{ft}$ from 1995 to 2001 (Huff and others, 2003). Associated with the water-level recovery has been an increase in nitrate $\left(\mathrm{NO}_{3}\right)$ concentrations from a background value of about $10 \mathrm{mg} / \mathrm{L}$ to in excess of the U.S Environmental Protection Agency (USEPA) maximum contaminant level (MCL) of $44 \mathrm{mg} / \mathrm{L}$ as nitrate (U.S. Environmental Protection Agency, 2002), which is equivalent to 10 $\mathrm{mg} / \mathrm{L}$ as nitrogen. In order to manage the ground-water resources and to identify future mitigating measures, an understanding of the source of the $\mathrm{NO}_{3}$ contamination and the hydrologic processes controlling the movement of the contamination is needed.

\section{Purpose and Scope}

In 1997, the U.S. Geological Survey (USGS) began a cooperative study with HDWD and Mojave Water Agency (MWA) to evaluate the effect of present and future artificial recharge in the Warren subbasin. The objectives of this study were to (1) evaluate the sources of the high-nitrate concentrations that occurred after the start of the artificial recharge program, (2) develop ground-water flow and solute-transport models to better understand the source and transport of nitrates in the aquifer system, and (3) utilize the calibrated models to evaluate the possible effect of a proposed conjunctive-use project. These objectives were accomplished by collecting water-level and waterquality data for the subbasin and assessing changes that have occurred since artificial recharge began. Collected data were used to calibrate the ground-water flow and solute-transport models.

\section{General Description of Study Area}

The 19-square-mile Warren subbasin is about 25 mi north of Palm Springs and 100 mi east of Los Angeles in the southwestern part of the Mojave Desert in southern California and is part of the Morongo ground-water basin (fig. 1). The principal population center in the subbasin is the Town of Yucca Valley. The Warren subbasin is bounded on the north by the San Bernardino Mountains and the Pinto Mountain Fault, on the south by the Little San Bernardino Mountains, on the west by a natural topographic and ground-water divide, and on the east by a series of faults that make up the Yucca barrier [which was initially defined by waterlevel differences on either side of the barrier of as much as $400 \mathrm{ft}$ (Lewis, 1972)].

Data collected for this study indicate that the areal extent of the water-bearing deposits is much smaller (about $5.5 \mathrm{mi}^{2}$ versus $19 \mathrm{mi}^{2}$ ) than that of the subbasin. These water-bearing deposits are referred to in this report as the Warren ground-water basin. Faults separate the ground-water basin into five hydrogeologic units; the west, midwest, mideast, east and northeast hydrogeologic units (fig 1).

The climate of the area, typical of the southern Mojave Desert, is characterized by sunny days, low rainfall, hot summers, and relatively cool winters. The average annual precipitation at Yucca Valley is about 6.75 in. (Lewis, 1972). Most of this precipitation is lost through evaporation; the total average monthly evapotranspiration rate of a high desert valley is 66.5 in./yr (California Irrigation Management Information System, 2002).

Figure 2 shows the land use in the Warren ground-water basin for 1952-53, 1965, 1977, and 1993. Land use was grouped into five categories: (1) residential (single-family residences), (2) multi-family residences (primarily mobile home parks), (3) commercial, (4) irrigated recreational fields (playing fields/golf course), and (5) undeveloped. Figure 3 shows the area in acres for each land-use category and year shown in figure 2. Note that the largest increase in area of irrigated recreational fields occurred in 1956 when a 105-acre golf course was constructed at the western end of the basin. 

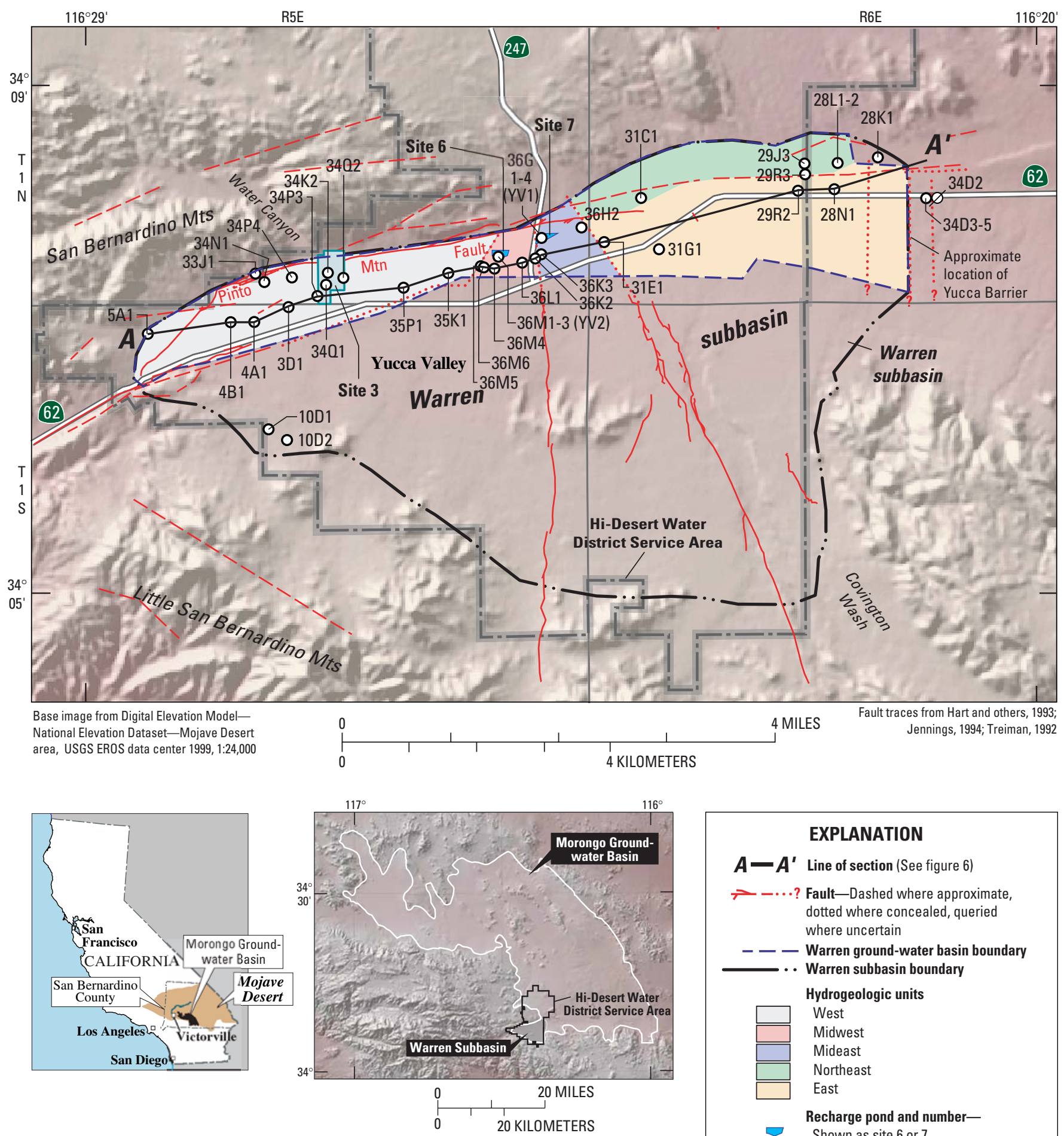

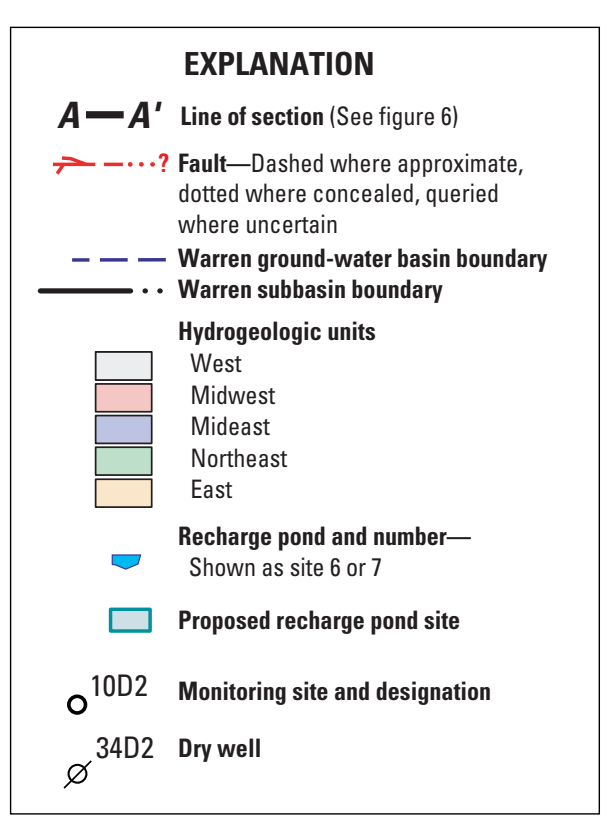

Figure 1. Location of study area, Warren subbasin, San Bernardino County, California. 


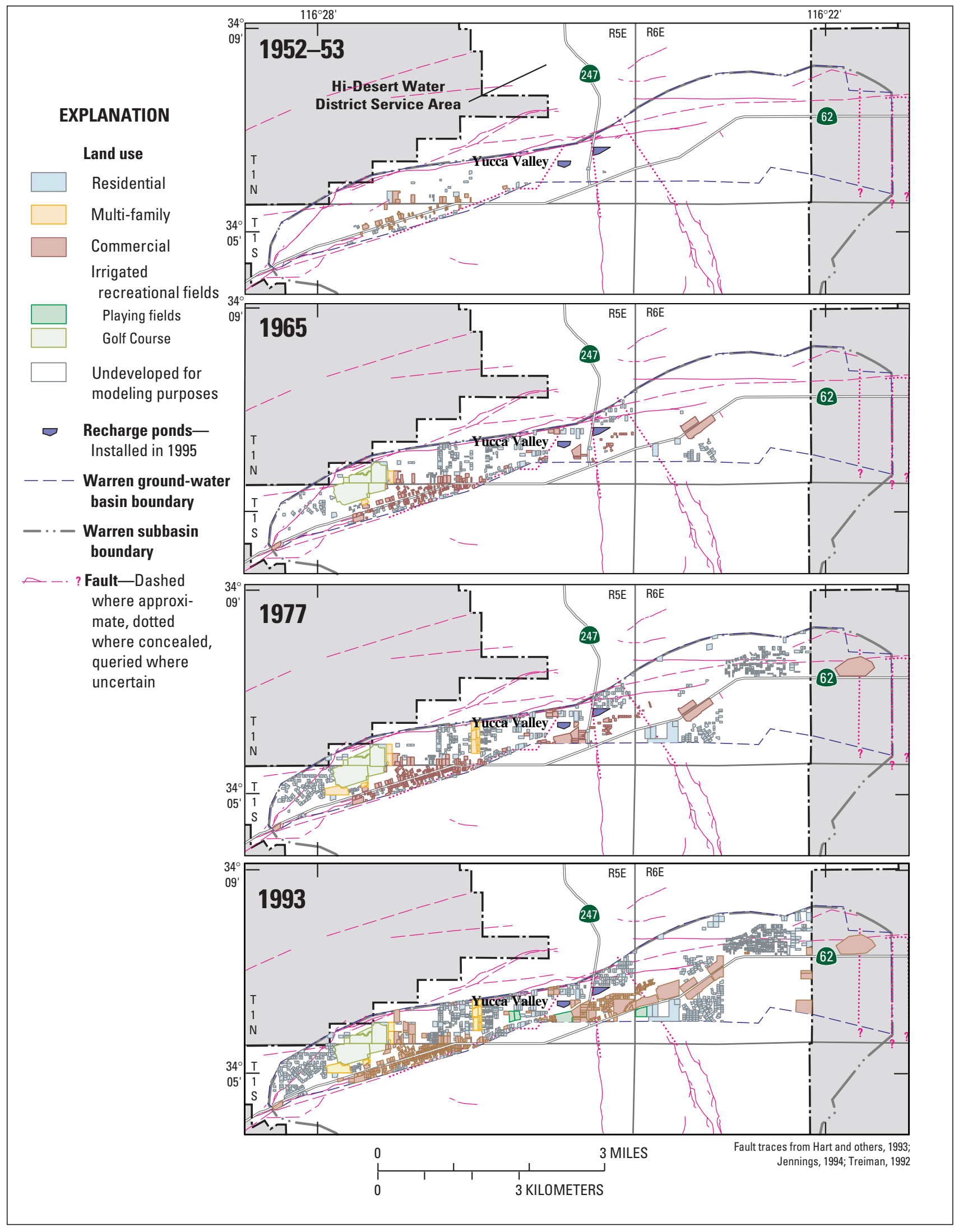

Figure 2. Land use for 1952-53, 1965, 1977, and 1993 in Warren ground-water basin, San Bernardino County, California. 


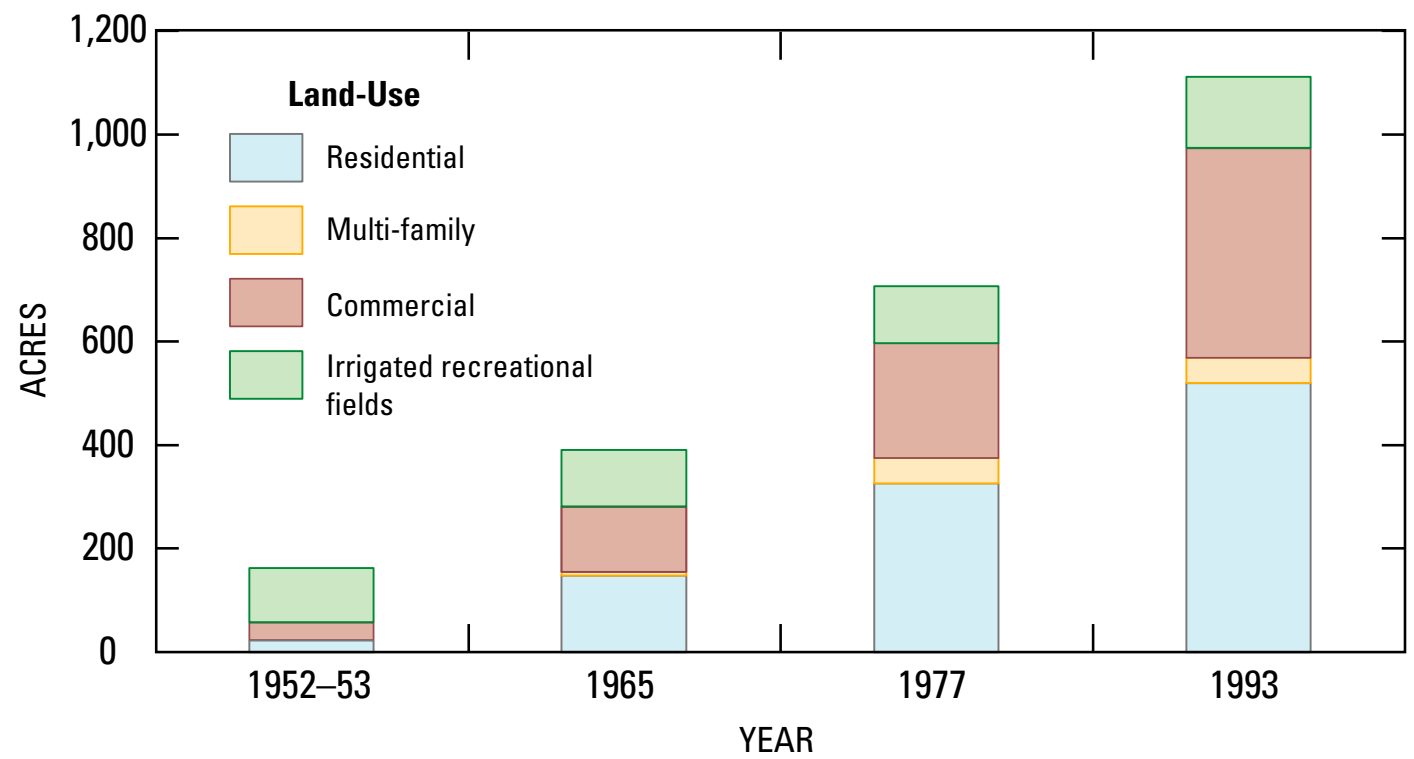

Figure 3. Total residential, multi-family, commercial, and irrigated recreational field acreage for 1952-53, 1965, 1977, and 1993 in Warren ground-water basin, San Bernardino County, California. 


\section{Multiple-Well Monitoring Sites}

The USGS, in cooperation with MWA, installed two multiple-well monitoring sites [1N/5E-36G1-4 (YV1) and 1N/5E-36M1-3 (YV2)] containing a total of seven piezometers (fig. 1). The monitoring sites were constructed during August and October 1993 to help define the stratigraphic units and ground-water system, measure water levels and water quality, and monitor changes related to the planned artificial recharge of imported water. Monitoring site YV1 was constructed near the site 7 recharge pond in the mideast hydrogeologic unit and monitoring site YV2 was constructed near the site 6 recharge pond in the midwest hydrogeologic unit (fig. 1) (the ponds were installed in 1994 and recharge operations started in 1995). Monitoring site YV1 contains four (YV1-570, YV1-400, YV1-305, and YV1-230) and monitoring site YV2 contains three (YV2-570, YV2-390, and YV2300) 2-in.-diameter polyvinyl chloride (PVC) piezometers each perforated at different depths (table 1) to allow depth-dependent measurements and sampling. The design of each multiple-well monitoring site was determined by examining the drill cuttings and geophysical logs collected from each borehole. The lithologic, geophysical, and well-construction data for these sites are presented by Huff and others (2003).

\section{Acknowledgments}

The authors thank the personnel of Hi-Desert Water District for providing all available data for production wells and for assistance during sampling. The authors also thank the following USGS personnel: Dr. J.K. Böhlke for nitrogen isotope analyses, Dr. Larry B. Barber for fluorescence and dissolved organic carbon analyses, Dr. Jeff Cahill for caffeine and pharmaceutical analyses, and David Leighton, Steven Predmore, and David Valentine for their GIS expertise.

\section{GEOHYDROLOGY}

The geohydrologic framework of the Warren subbasin was defined by summarizing previously published research (Dibblee, 1967; Lewis, 1972; and Hopson, 1998), mapping the surficial geology of the subbasin, and by collecting geologic and hydrologic data from existing wells. Table 1 lists the available well-construction data for wells used in this report.

\section{Geology}

Stratigraphic Units

For this report, the surficial geologic units are grouped into three generalized stratigraphic units: (1) a basement complex of pre-Tertiary granitic and metamorphic rocks $(\mathrm{Bc}),(2)$ Tertiary sedimentary rocks (Ts), (3) Quaternary alluvial deposits [including Quaternary older fan deposits (Qof), Quaternary fan deposits (Qf), Quaternary younger fan deposits (Qyf), Quaternary alluvium (Qa), and Quaternary younger alluvium (Qya)] (fig. 4). The definitions of the stratigraphic units were based on analyses of drillers' logs and geophysical data; these data are on file at the USGS office in San Diego, California.

The pre-Tertiary basement complex (fig. 4, Bc) underlies the Warren subbasin and crops out in the surrounding hills. Except for small quantities of water in the fractures and weathered zones in this unit, the basement complex is not a major water-bearing unit.

Tertiary sedimentary deposits (ig. 4, Ts) crop out at Burnt Mountain, a prominent elongate hill in the southern part of Warren subbasin, and overlie the basement complex throughout most of the study area. This unit consists of semi-consolidated fanglomerate deposits, which contain granitic and gneissic clasts derived from the surrounding bedrock, and probably yields only small quantities of water to wells. Based on drillers' logs and geophysical data, these deposits reach a maximum thickness of about $2,000 \mathrm{ft}$ and are much less permeable than the overlying alluvial-fan deposits and alluvium. 
Table 1. Well-construction data for wells in the Warren ground-water basin , California

[ft, foot; -, no data]

\begin{tabular}{|c|c|c|c|c|c|c|c|}
\hline State well No. & Local name & $\begin{array}{c}\text { Altitude of } \\
\text { land surface } \\
\text { (ft) }\end{array}$ & $\begin{array}{c}\text { Borehole } \\
\text { depth } \\
\text { (ft) }\end{array}$ & $\begin{array}{c}\text { Date of } \\
\text { construction }\end{array}$ & $\begin{array}{c}\text { Depth of } \\
\text { well } \\
\text { (ft) }\end{array}$ & $\begin{array}{l}\text { Top of } \\
\text { perforated } \\
\text { interval } \\
\text { (ft) }\end{array}$ & $\begin{array}{l}\text { Bottom of } \\
\text { perforated } \\
\text { interval } \\
\text { (ft) }\end{array}$ \\
\hline 1N/5E-28M1 & - & 3,658 & - & - & - & - & - \\
\hline $1 \mathrm{~N} / 5 \mathrm{E}-28 \mathrm{~N} 2$ & - & 3,660 & - & - & - & - & - \\
\hline IN/5E-33J1 & - & 3,371 & 310 & $10 / 11 / 1956$ & 310 & 245 & 310 \\
\hline 1N/5E-33Q1 & Blue Skies GC & 3,327 & 305 & - & 305 & - & - \\
\hline 1N/5E-34K1 & $2 \mathrm{~W}$ & 3,380 & 378 & $8 / 1946$ & 378 & 228 & 378 \\
\hline $1 \mathrm{~N} / 5 \mathrm{E}-34 \mathrm{~K} 2$ & $2 \mathrm{~W}$ & 3,380 & 640 & 7/9/1972 & 640 & 340 & 640 \\
\hline $1 \mathrm{~N} / 5 \mathrm{E}-34 \mathrm{~N} 1$ & $5 \mathrm{~W}$ & 3,340 & 286 & 1956 & 281 & 200 & 281 \\
\hline $1 \mathrm{~N} / 5 \mathrm{E}-34 \mathrm{~N} 3$ & $5 \mathrm{~W}$ & 3,344 & 551 & $12 / 2 / 1968$ & 548 & 245 & 545 \\
\hline \multirow[t]{4}{*}{ 1N/5E-34P3 } & $7 \mathrm{~W}$ & 3,340 & 600 & 9/1987 & 590 & 340 & 460 \\
\hline & & & & & & 480 & 500 \\
\hline & & & & & & 520 & 540 \\
\hline & & & & & & 560 & 580 \\
\hline \multirow[t]{2}{*}{$1 \mathrm{~N} / 5 \mathrm{E}-34 \mathrm{P} 4$} & $10 \mathrm{~W}$ & 3,360 & 1,031 & $1 / 22 / 1989$ & 1,020 & 398 & 640 \\
\hline & & & & & & 650 & 1,010 \\
\hline \multirow[t]{4}{*}{ 1N/5E-34Q1 } & $6 \mathrm{~W}$ & 3,360 & 757 & $10 / 20 / 1972$ & 757 & 370 & 396 \\
\hline & & & & & & 410 & 421 \\
\hline & & & & & & 445 & 475 \\
\hline & & & & & & 540 & 751 \\
\hline \multirow[t]{3}{*}{ 1N/5E-34Q2 } & $9 \mathrm{~W}$ & 3,360 & 1,000 & $8 / 12 / 1988$ & 990 & 360 & 560 \\
\hline & & & & & & 580 & 665 \\
\hline & & & & & & 680 & 900 \\
\hline \multirow[t]{2}{*}{$1 \mathrm{~N} / 5 \mathrm{E}-35 \mathrm{~K} 1$} & $11 \mathrm{~W}$ & 3,260 & 860 & 2/9/1989 & 860 & 300 & 480 \\
\hline & & & & & & 580 & 850 \\
\hline $1 \mathrm{~N} / 5 \mathrm{E}-35 \mathrm{P} 1$ & $3 \mathrm{~W}$ & 3,280 & 504 & 1960 & 504 & 194 & 494 \\
\hline 1N/5E-36G1 & YV1-570 & $3,221.5$ & 580 & 8/1/1993 & 570 & 550 & 570 \\
\hline 1N/5E-36G2 & YV1-400 & $3,221.5$ & 580 & 8/1/1993 & 400 & 380 & 400 \\
\hline 1N/5E-36G3 & YV1-305 & $3,221.5$ & 580 & 8/1/1993 & 305 & 285 & 305 \\
\hline 1N/5E-36G4 & YV1-230 & $3,221.5$ & 580 & 8/1/1993 & 230 & 210 & 230 \\
\hline $1 \mathrm{~N} / 5 \mathrm{E}-36 \mathrm{H} 2$ & $18 \mathrm{E}$ & 3,210 & 1,220 & $6 / 22 / 1990$ & 1,000 & 400 & 1,000 \\
\hline $1 \mathrm{~N} / 5 \mathrm{E}-36 \mathrm{~K} 1$ & HDWD-1 & 3,230 & 333 & 1946 & 333 & - & - \\
\hline $1 \mathrm{~N} / 5 \mathrm{E}-36 \mathrm{~K} 2$ & $9 \mathrm{E}$ & 3,230 & 800 & $4 / 25 / 1975$ & 800 & 323 & 780 \\
\hline \multirow[t]{3}{*}{ 1N/5E-36K3 } & $14 \mathrm{E}$ & 3,230 & 1,610 & $2 / 12 / 90$ & 1,115 & 550 & 750 \\
\hline & & & & & & 790 & 830 \\
\hline & & & & & & 835 & 1,115 \\
\hline 1N/5E-36L1 & $7 \mathrm{E}$ & 3,230 & 736 & $8 / 11 / 1972$ & 735 & 275 & 725 \\
\hline $1 \mathrm{~N} / 5 \mathrm{E}-36 \mathrm{M} 1$ & YV2-570 & $3,240.4$ & 600 & $10 / 22 / 1993$ & 570 & 550 & 570 \\
\hline $1 \mathrm{~N} / 5 \mathrm{E}-36 \mathrm{M} 2$ & YV2-390 & $3,240.4$ & 600 & $10 / 22 / 1993$ & 390 & 370 & 390 \\
\hline $1 \mathrm{~N} / 5 \mathrm{E}-36 \mathrm{M} 3$ & YV2-300 & $3,240.4$ & 600 & $10 / 22 / 1993$ & 300 & 280 & 300 \\
\hline $1 \mathrm{~N} / 5 \mathrm{E}-36 \mathrm{M} 4$ & $12 \mathrm{E}$ & 3,245 & 900 & 2/28/1985 & 800 & 400 & 800 \\
\hline 1N/5E-36M5 & $16 \mathrm{E}$ & 3,245 & 1,480 & 4/14/1990 & 1,450 & 920 & 1,450 \\
\hline 1N/5E-36M6 & $17 \mathrm{E}$ & 3,245 & 910 & $6 / 22 / 1990$ & 800 & 450 & 800 \\
\hline 1N/6E-28K1 & - & 3,026 & - & - & 300 & - & - \\
\hline
\end{tabular}


Table 1. Well-construction data for wells in the Warren ground-water basin, California-Continued

\begin{tabular}{|c|c|c|c|c|c|c|c|}
\hline State well No. & Local name & $\begin{array}{c}\text { Altitude of } \\
\text { land surface } \\
\text { (ft) }\end{array}$ & $\begin{array}{c}\text { Borehole } \\
\text { depth } \\
\text { (ft) }\end{array}$ & $\begin{array}{c}\text { Date of } \\
\text { construction }\end{array}$ & $\begin{array}{c}\text { Depth of } \\
\text { well } \\
\text { (ft) }\end{array}$ & $\begin{array}{c}\text { Top of } \\
\text { perforated } \\
\text { interval } \\
\text { (ft) }\end{array}$ & $\begin{array}{c}\text { Bottom of } \\
\text { perforated } \\
\text { interval } \\
\text { (ft) }\end{array}$ \\
\hline 1N/6E-28L1 & - & $2,971.04$ & - & - & - & - & - \\
\hline 1N/6E-28L2 & - & 3,065 & - & - & 300 & - & - \\
\hline 1N/6E-28N1 & - & 3,107 & - & $4 / 1956$ & 500 & - & - \\
\hline 1N/6E-29H1 & - & 3,150 & - & - & 258 & - & - \\
\hline 1N/6E-29J1 & - & 3,110 & - & - & 0 & - & - \\
\hline $1 \mathrm{~N} / 6 \mathrm{E}-29 J 2$ & - & 3,100 & - & 1/8/1947 & 300 & - & - \\
\hline $1 \mathrm{~N} / 6 \mathrm{E}-29 J 3$ & $11 \mathrm{E}$ & 3,095 & 814 & $5 / 22 / 1982$ & 803 & 350 & 773 \\
\hline 1N/6E-29L1 & - & 3,150 & - & 8/1/1953 & 690 & 365 & 620 \\
\hline $1 \mathrm{~N} / 6 \mathrm{E}-29 \mathrm{~N} 1$ & - & 3,190 & - & 1954 & 414 & 238 & 397 \\
\hline 1N/6E-29R1 & - & 3,140 & - & 1948 & 306 & - & - \\
\hline 1N/6E-29R2 & - & 3,150 & - & - & - & - & - \\
\hline 1N/6E-29R3 & $13 \mathrm{E}$ & 3,105 & 714 & $10 / 12 / 1989$ & 680 & 360 & 660 \\
\hline $1 \mathrm{~N} / 6 \mathrm{E}-31 \mathrm{C} 1$ & $5 \mathrm{E}$ & 3,199 & 730 & 1971 & 730 & 200 & 730 \\
\hline $1 \mathrm{~N} / 6 \mathrm{E}-31 \mathrm{E} 1$ & HDWD MON 2 & 3,200 & - & - & - & - & - \\
\hline $1 \mathrm{~N} / 6 \mathrm{E}-31 \mathrm{G} 1$ & HDWD MON 1 & 3,250 & - & - & - & - & - \\
\hline 1N/6E-34D3 & Yucca Barrier-999 & 3,030 & 1,000 & 9/18/1999 & 999 & 979 & 999 \\
\hline 1N/6E-34D4 & Yucca Barrier-920 & 3,030 & 1,000 & 9/18/1999 & 920 & 900 & 920 \\
\hline 1N/6E-34D5 & Yucca Barrier-820 & 3,030 & 1,000 & 9/18/1999 & 820 & 780 & 820 \\
\hline \multirow[t]{5}{*}{ 1S/5E-3D1 } & $8 \mathrm{~W}$ & 3,340 & 1,043 & $7 / 28 / 1988$ & 940 & 400 & 500 \\
\hline & & & & & & 520 & 590 \\
\hline & & & & & & 608 & 620 \\
\hline & & & & & & 640 & 720 \\
\hline & & & & & & 740 & 940 \\
\hline $1 \mathrm{~S} / 5 \mathrm{E}-4 \mathrm{~A} 1$ & BSGC17 & 3,331 & 540 & $3 / 5 / 1962$ & 533 & 200 & 525 \\
\hline $1 \mathrm{~S} / 5 \mathrm{E}-4 \mathrm{~B} 1$ & BSGC1 & 3,339 & 320 & $7 / 7 / 1964$ & 320 & 25 & 315 \\
\hline $1 \mathrm{~S} / 5 \mathrm{E}-5 \mathrm{~A} 1$ & - & 3,554 & 390 & 1957 & 371 & 145 & 340 \\
\hline 1S/5E-10D2 & - & 3,590 & 100 & - & 100 & - & - \\
\hline
\end{tabular}




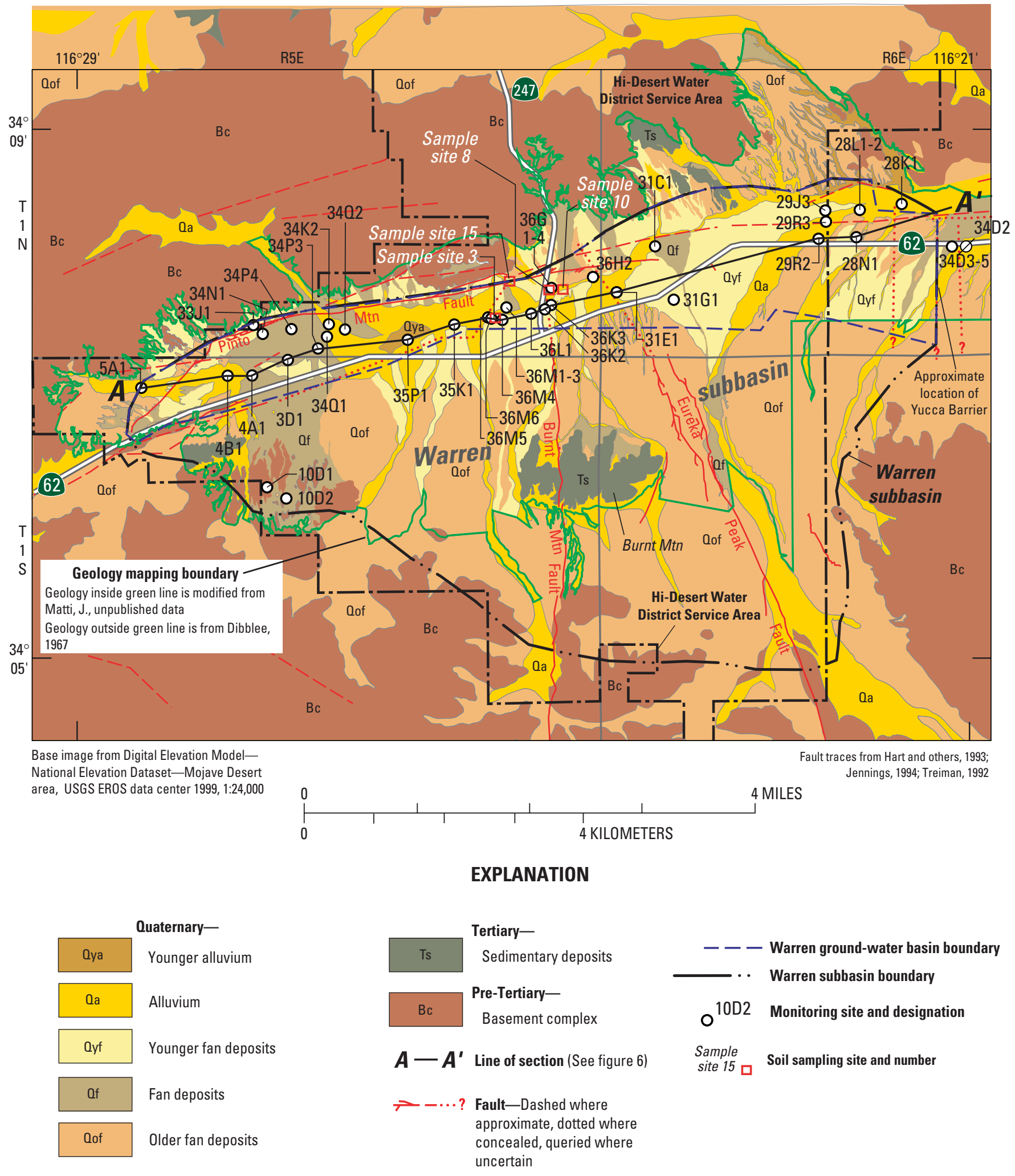

Figure 4. Generalized surficial geology, major faults, location of wells, and soil-sampling sites for the Warren subbasin, California. 
Quaternary alluvial fan deposits overlie the Tertiary deposits and basement complex throughout much of the basin (fig. 4), and range in thickness from a few feet along the boundary of the basin to more than $1,000 \mathrm{ft}$ near the center of the basin. These deposits are divided into older fan deposits (Qof), fan deposits (Qf), and younger fan deposits (Qyf). As a group, these fan deposits consist of poorly sorted sand and gravel containing detritus derived from neighboring mountains. The fan deposits are generally finer grained downslope toward the basin axis. The alluvial-fan deposits are unconsolidated at land surface and become slightly more consolidated at depth. Based on drillers' $\operatorname{logs}$ and specific-capacity tests, these deposits are generally less permeable than the overlying alluvium.

Quaternary alluvium (Qa, Qya) overlies the alluvial fan deposits primarily along the active washes in the basin and are about $0-100 \mathrm{ft}$ thick. The alluvium is the most permeable of the stratigraphic units; however, most of the alluvium lies within the unsaturated zone. Prior to ground-water development some of the alluvium was saturated. By the early 1990s water levels had declined as much as $300 \mathrm{ft}$ in the midwest hydrogeologic unit, and most of the alluvium became unsaturated.

\section{Depth to Basement Complex}

A gravity survey was used to understand the three-dimensional structure and estimate the depth to basement complex (thickness of the basin fill) of the Morongo ground-water basin (Roberts and others, 2002). The gravity data indicate an east-west linear basin parallel to the Pinto Mountain fault in the Warren subbasin, referred to as the Warren ground-water basin. The maximum depth of the ground-water basin may be greater than 3,000 ft about two miles east of Highway 247 (fig. 5).

\section{Faults and Ground-Water Barriers}

Several faults cross the Warren subbasin (fig. 4) and have either juxtaposed the pre-Tertiary basement complex against unconsolidated alluvial deposits, or displaced preferential flow paths in unconsolidated alluvial deposits. This juxtaposition and displacement, along with cementation, compaction, and extreme deformation of the water-bearing deposits adjacent to faults, can create low-permeability zones that can act as barriers to ground-water flow.

The most prominent of these faults is the Pinto Mountain fault which trends east-west along the entire northern boundary of the basin and acts as a barrier to ground-water flow from the north. An unnamed fault separates the west and the midwest hydrogeologic units. The approximate location of this fault is based on water-level data. Two other faults that affect water levels are the north-south trending Burnt Mountain fault, which separates the midwest and the mideast hydrogeologic units; and northwest-southeast trending Eureka Peak fault, which separates the mideast and the east hydrogeologic units. The eastern boundary of the Warren subbasin is the Yucca Barrier (Lewis, 1972). The barrier was located on the basis of water-level data; water levels on the east side of the Yucca Barrier are as much as $400 \mathrm{ft}$ lower than water levels on the west side of the fault (Lewis, 1972). Water-level data collected for this study suggest that the barrier may consist of several parallel unnamed north-south trending faults. Other faults may be present in the Warren subbasin, however they have not been defined by geologic mapping or water-level data.

\section{Definition of the Aquifer System}

The water-bearing deposits in the Warren ground-water basin are the Quarternary alluvial deposits and the Tertiary sedimentary deposits. Using lithologic and downhole geophysical logs, the alluvial deposits were divided into three aquifers (referred to as the upper, middle, and lower alluvial aquifers) and sedimentary deposits comprised one aquifer (referred to as the deep aquifer). Transmissivity estimates reported in this section are based on specific-capacity tests reported in drillers' logs and performed by Southern California Edison; these data are on file at the USGS office in San Diego, California. 


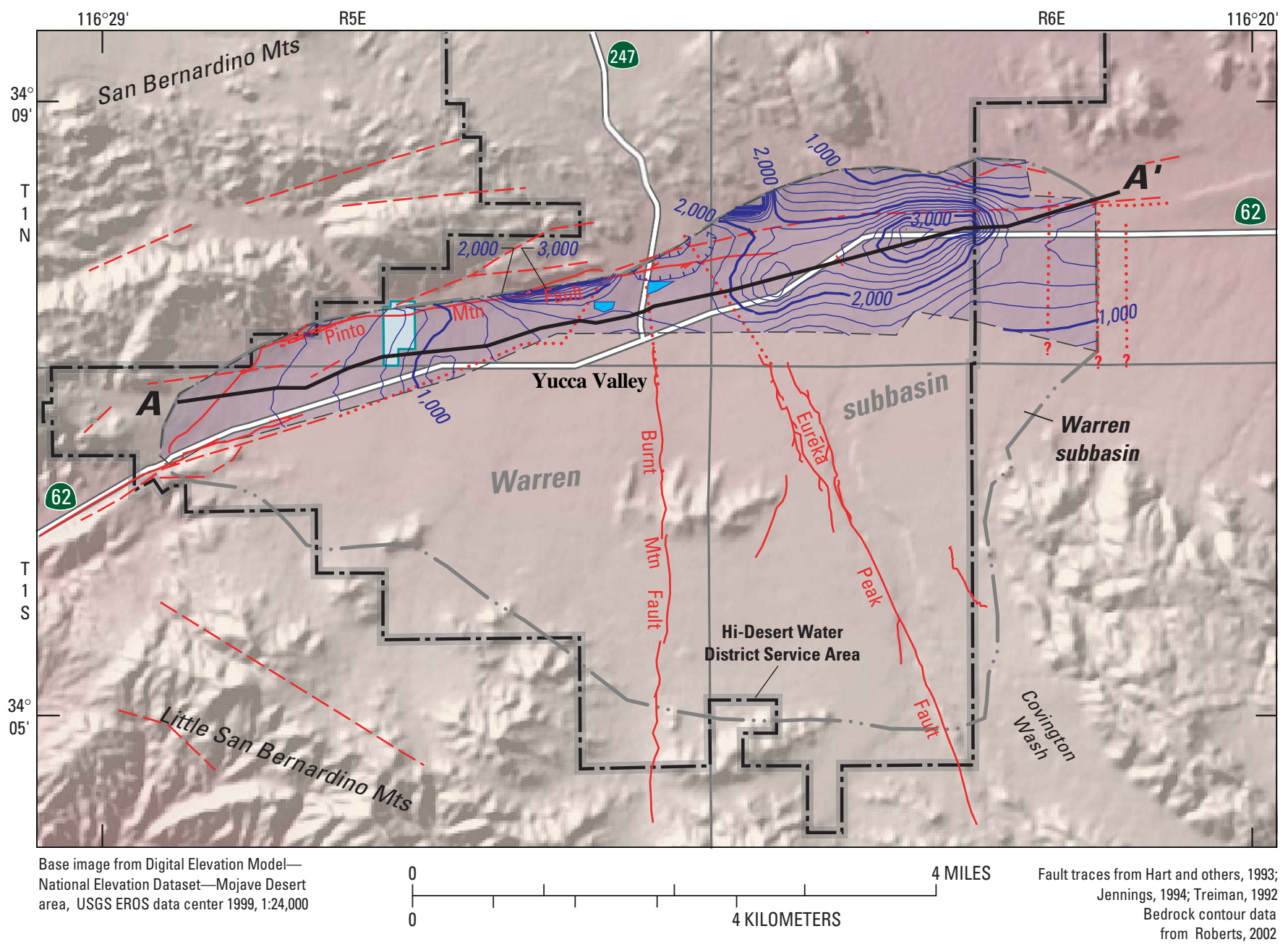

\section{EXPLANATION}
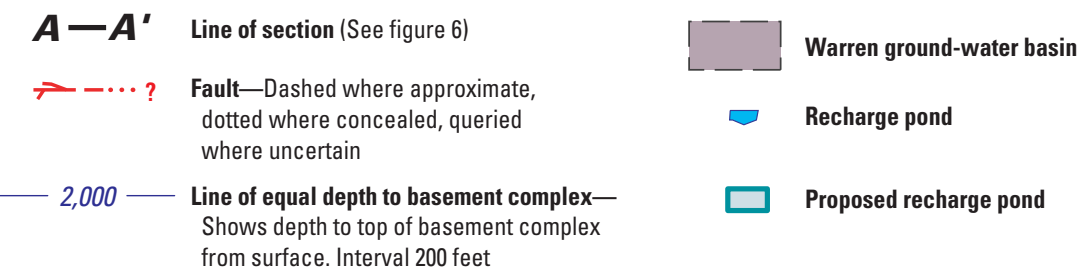

Figure 5. Depth to basement complex based on gravity data, Warren subbasin, California. 
The upper aquifer consists of the saturated part of the alluvium and the upper part of the alluvial-fan deposits and the thickness of this aquifer ranges from about $300 \mathrm{ft}$ in the western part of the basin to less than $100 \mathrm{ft}$ in the eastern part of the basin (fig. 6). In general, the aquifer extends from about $2,900 \mathrm{ft}$ above sea level to the water table. This aquifer is mainly fineto-coarse grained sand with occasional gravel as indicated by drillers' logs and downhole geophysical $\operatorname{logs}$ (relatively high resistivity opposite this aquifer). No production wells are perforated solely in the upper aquifer. Water-level declines from the late-1940s to the early 1990s lowered the water table below the bottom of this aquifer in the midwest and mideast hydrogeologic units.

The middle aquifer is contained in the alluvialfan deposit and is about $200 \mathrm{ft}$ thick. This aquifer consists mainly of silty sand and the downhole geophysical logs indicate lower resistivity than those of the upper aquifer (fig. 6). Estimates of transmissivity, based on specific-capacity data from wells perforated in the upper and middle aquifers, range from about 920 to $6,450 \mathrm{ft}^{2} / \mathrm{d}$.

The lower aquifer is contained within the lower part of the alluvial fan deposits and is about $600 \mathrm{ft}$ thick. The aquifer consists mainly of indurated silty sand, and the downhole geophysical logs show lower resistivity than those of the middle aquifer (fig. 6). There are two wells perforated only in the lower aquifer; all other wells perforated in the lower aquifer are also perforated in a combination of the upper, middle, or deep aquifers. For the wells perforated only in the lower aquifer, estimated transmissivity range from about 80 to $3,060 \mathrm{ft}^{2} / \mathrm{d}$.

The deep aquifer is contained within the Tertiary deposits and is as much as 2,000 ft thick. The aquifer consists mainly of semi-consolidated fanglomerates, and the downhole geophysical logs indicate very low resistivity (fig. 6). There are no wells perforated only in the deep aquifer; however, there are two wells perforated in the lower and deep aquifers. For these wells, estimates of transmissivity range from 70 to $570 \mathrm{ft}^{2} / \mathrm{d}$.

\section{Natural Recharge and Discharge}

Natural recharge to Warren ground-water basin is small and may be less than 200 acre-ft/yr (Koebig and Koebig, 1966). Average annual precipitation at Yucca Valley is about 6.75 in.; however, the precipitation on unconsolidated deposits contributes negligible quantities of recharge, and no perennial streams empty into the basin (Lewis, 1972). Small amounts of recharge may be contributed from runoff of precipitation in the Little San Bernardino Mountains to the south and San Bernardino Mountains to the north (fig. 1). Water samples from wells located near Water Canyon [1N/5E-34P4 (10W) and -34Q2 (9W)] (fig. 1) contained tritium indicating that recharge occurred after about 1952 when $800 \mathrm{~kg}$ of tritium was released into the atmosphere by atmospheric testing of nuclear weapons (Michel, 1976). However in the midwest and the mideast hydrogeologic units, samples from wells 1N/5E-36M1 (YV2-570) and 1N/5E-36G1 (YV1-570) contained no tritium and had carbon-14 activities of 69.3 and 79.5 percent modern carbon, respectively, indicating an uncorrected carbon-14 age of 2,000 to 3,000 years. Although uncorrected carbon-14 ages are subject to considerable uncertainty (Davis and Bentley, 1982), the data indicate that the midwest and mideast hydrogeologic units are not receiving recent recharge.

Natural discharge from the Warren ground-water basin is outflow at the Yucca Barrier. The depth to ground water under steady-state predevelopment conditions was greater than $80 \mathrm{ft}$; therefore, evapotranspiration is negligible. Natural outflow must equal natural inflow under steady-state predevelopment conditions; therefore, the outflow at the Yucca Barrier may be less than 200 acre-ft/yr.

\section{Ground-Water Development and Artificial Recharge}

The first public water-supply well was drilled in Yucca Valley in 1949 (Lewis, 1972). However, significant ground-water development did not start until 1956, when an irrigation well (well 1N/5E-33Q1) was drilled for a 105-acre golf course that was constructed in the west hydrogeologic unit [additional wells were drilled in 1962 and 1964 (wells 1S/5E-4A1 and 4B1, respectively)]. Presently, there are 18 publicsupply wells in the Warren ground-water basin. 


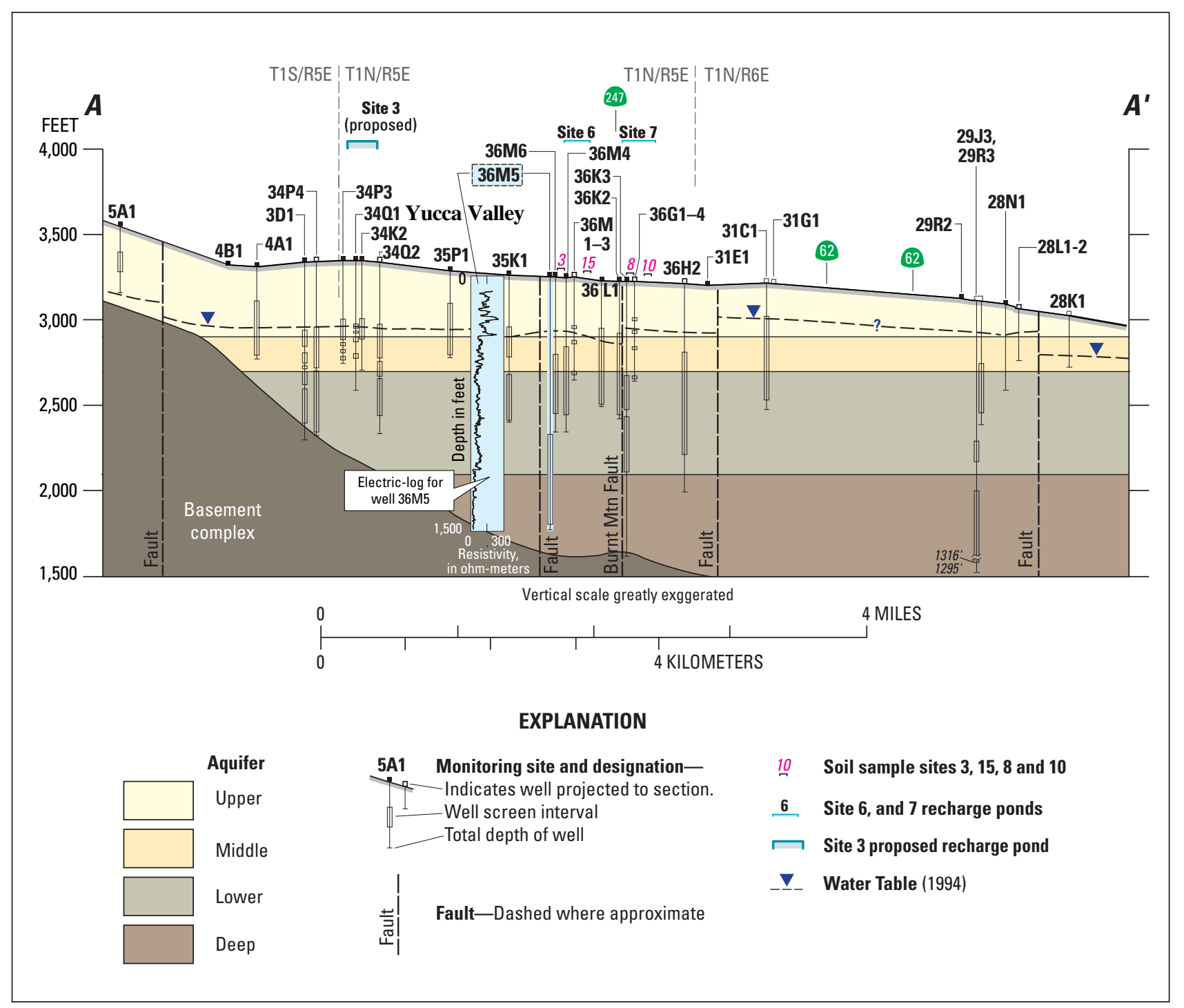

Figure 6. Geologic section along section line $A-A^{\prime}$ (see fig. 1) showing locations and depths of production and monitoring wells; locations of the recharge sites; and the upper, middle, lower, and deep aquifer systems of the Warren ground-water basin, San Bernardino County, California. 
Total annual pumpage data for 1949-69 were compiled by Lewis (1972); pumpage data from 1970 to 1990 were not available and were estimated from population data and assuming a per capita water usage of about $130 \mathrm{gal} / \mathrm{d}$. The $1970-90$ data were estimated using linearly interpolated population data; that is, population data were published for 1967, 1985, and 1992; the missing population data were linearly interpolated between 1967-85 and 1985-92. The estimated population for each year was then multiplied by the per capita water usage yielding a total water demand. Recorded annual and monthly pumpage data (HDWD, written commun., 2002) were available for 1991-2001. The average annual pumpage from 1956 to 2001 was about 1,700 acre-ft and the total pumpage in 2001 was about 2,600 acre-ft; the total annual pumpage from 1956 to 2001 is shown in figure 7.

Sources of artificial recharge to the basin include septic-tank effluent (septage), infiltration of irrigationreturn flow from the golf course and other irrigated fields, and spreading of imported water from the SWP in recharge ponds. Wastewater from homes and businesses in Yucca Valley is disposed of using septic tanks that separate the floating and settleable solids from the wastewater and discharge the clarified wastewater through leach lines. The wastewater percolates from the leach lines through the unsaturated zone and eventually recharges the underlying ground water. The quantity and distribution of recharge from septic tanks and infiltrated irrigation-return flows were estimated using land-use maps. The quantity of imported SWP water is reported by the HDWD.

Land-use maps developed for this study for 1952-53, 1965, 1977, and 1993 (fig. 2) were used to estimate the quantity and distribution of potential artificial recharge from septage. The quantity of septictank wastewater potentially recharging the underlying ground water at any given time at a household was estimated by assuming an average per capita septictank discharge of $70 \mathrm{gal} / \mathrm{d}$ (Eckenfelder, 1980). Land use classified as residential was assumed to have two households per acre and three persons per household; land use classified as multi-family was assumed to have 16 households per acre and two persons per household. Land use classified as commercial was assumed to have a per acre septic-tank discharge of 1,000 gal/d (Linsley and Franzini, 1979). The potential quantity of septictank seepage recharging the underlying ground water for different land-use categories is presented in table 2. The total potential recharge rate in acre- $\mathrm{ft} / \mathrm{yr}$ for each land-use map was 711 (1952-53, assuming the construction of the golf course), 915 (1965), 1,212 (1977), and 1,688 (1993).

Recharge from the infiltration of irrigation-return flow was estimated for the golf course and other grass fields in the ground-water basin using the land-use maps for 1952-53, 1965, 1977, and 1993 (fig. 2) and assuming that the consumptive use for grass was about $6.3 \mathrm{ft} / \mathrm{yr}$ per unit area (Sandra Owen-Joyce, U.S.

Geological Survey, written commun., 1996). Assuming that the irrigation efficiency of the grass areas is about 50 percent (twice as much water is applied than is used consumptively), then the quantity of irrigation-return flows would be equal to the quantity used consumptively by the grass.

As a result of large water-level declines since the 1950s, HDWD began to artificially recharge the basin using imported SWP water purchased from MWA in 1995. In 1994, two recharge ponds (sites 6 and 7 in fig. 1) were constructed near the center of the basin to impound imported water while it infiltrated into the ground-water system. Recharge began during February 1995 (fig. 8) and by the end of December 2001, about 24,335 acre- $\mathrm{ft}$ of water had been released to the recharge ponds. The artificial recharge program operated on a year-round basis; however, there were intermittent months when water was not recharged.

\section{Ground-Water Levels and Movement}

Ground-water data for 1958 and 1969 (Lewis, 1972), 1994 (Trayler and Koczot, 1995) and 1998 (Smith and Pimentel, 2000) were used to describe ground-water movement in the study area. For the purposes of this study, it was assumed that 1958 ground-water levels (fig. 9A) represent predevelopment conditions. In 1958, ground-water levels ranged from 3,400 to $3,100 \mathrm{ft}$ above sea level in the west hydrogeologic unit, from 3,100 to $3,000 \mathrm{ft}$ above sea level in the midwest and mideast hydrogeologic units, and from 3,000 to 2,800 ft above sea level in the northeast and east hydrogeologic units (igs. 1 and $\underline{9 A}$ ). Regional ground-water movement was easterly and had an average hydraulic gradient of about $0.01 \mathrm{ft} / \mathrm{ft}$. 


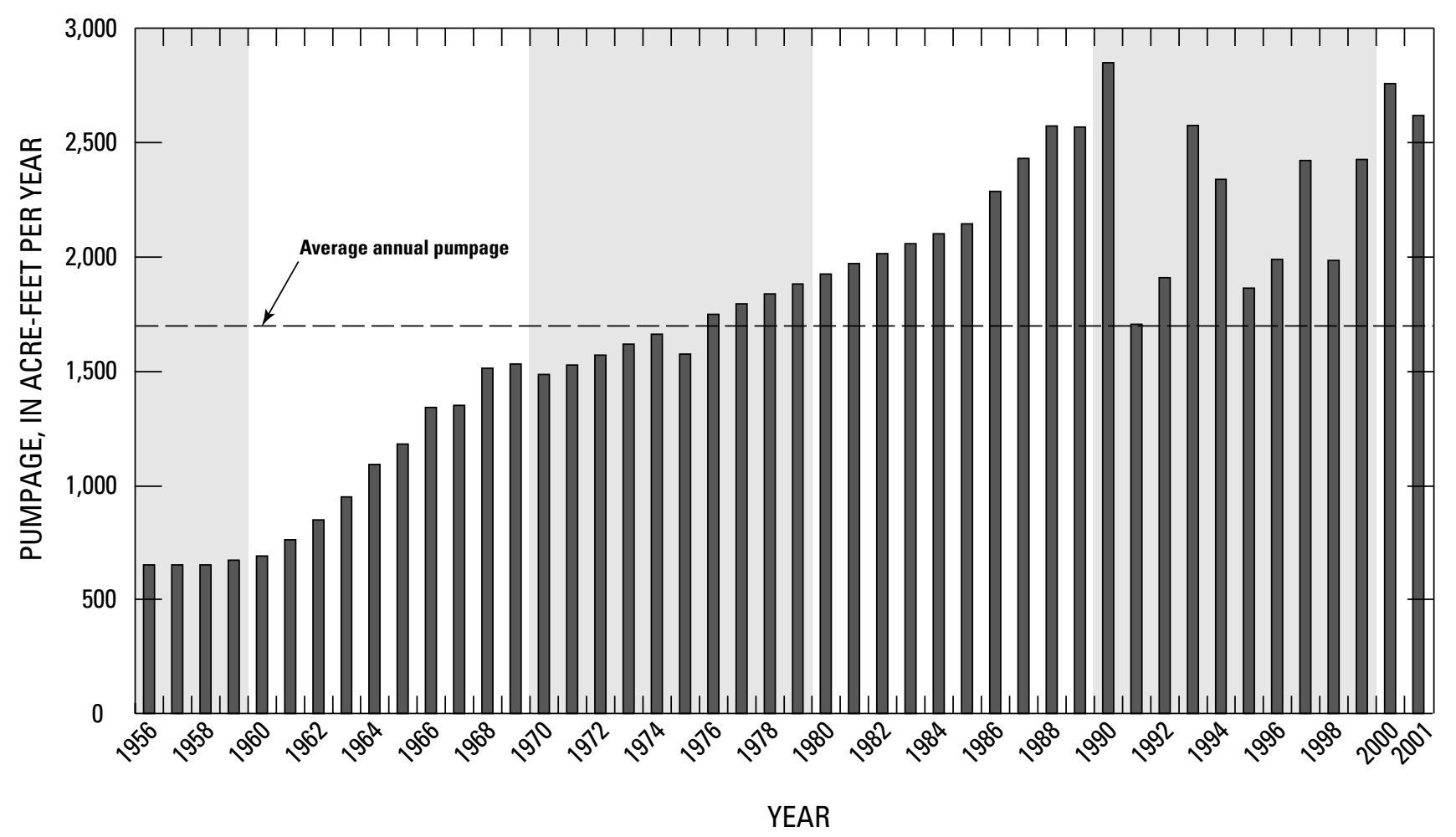

Figure 7. Total annual pumpage, 1956-2001, Warren ground-water basin, San Bernardino County, California. 
Table 2. Potential quantity of septic-tank seepage and infiltrated irrigation-return flow for different land-use categories in Warren groundwater basin, California

[Rate for residential land-use category calculated by multiplying 70 gallons/day/person by 3 people/house by 2 houses/acre; rate for multi-family land-use category calculated by multiplying 70 gallons/day/person by 2 people/house by 16 houses/acre; rate for commercial land-use category assumed to be 1,000 gallons/day/acre; rate for consumptive use for irrigrated recreational fields assumed to be $6.3 \mathrm{ft} / \mathrm{yr} / \mathrm{acre}$; gal/d, gallon per day; acre-ft/yr, acre foot per year; na, not applicable]

\begin{tabular}{|c|c|c|c|c|c|}
\hline \multirow{2}{*}{$\begin{array}{c}\text { Land-use } \\
\text { year }\end{array}$} & \multirow{2}{*}{$\begin{array}{l}\text { Land-use } \\
\text { category }\end{array}$} & \multirow{2}{*}{$\begin{array}{c}\text { Area in } \\
\text { acres }\end{array}$} & \multirow{2}{*}{ Rate } & \multicolumn{2}{|c|}{$\begin{array}{c}\text { Potential septic-tank } \\
\text { seepage and irrigation-return flow }\end{array}$} \\
\hline & & & & in gal/d & in acre-ft/yr \\
\hline \multirow[t]{4}{*}{$1952-53$} & Residential & 23 & 420 & 9,660 & 11 \\
\hline & Multi-family & 0 & 2,240 & 0 & 0 \\
\hline & Commercial & 34 & 1,000 & 34,000 & 38 \\
\hline & Irrigated recreational fields 1 & 105 & 6.3 & na & 662 \\
\hline \multirow[t]{4}{*}{1965} & Residential & 148 & 420 & 62,160 & 70 \\
\hline & Multi-family & 7 & 2,240 & 15,680 & 18 \\
\hline & Commercial & 125 & 1,000 & 125,000 & 140 \\
\hline & Irrigated recreational fields & 109 & 6.3 & na & 687 \\
\hline \multirow[t]{4}{*}{1977} & Residential & 325 & 420 & 136,500 & 153 \\
\hline & Multi-family & 49 & 2,240 & 109,760 & 123 \\
\hline & Commercial & 222 & 1,000 & 222,000 & 249 \\
\hline & Irrigated recreational fields & 109 & 6.3 & na & 687 \\
\hline \multirow[t]{4}{*}{1993} & Residential & 518 & 420 & 217,560 & 244 \\
\hline & Multi-family & 49 & 2,240 & 109,760 & 123 \\
\hline & Commercial & 403 & 1,000 & 403,000 & 452 \\
\hline & Irrigated recreational fields & 138 & 6.3 & na & 869 \\
\hline
\end{tabular}

\footnotetext{
${ }^{1}$ Irrigated recreational fields installed in 1956.
} 


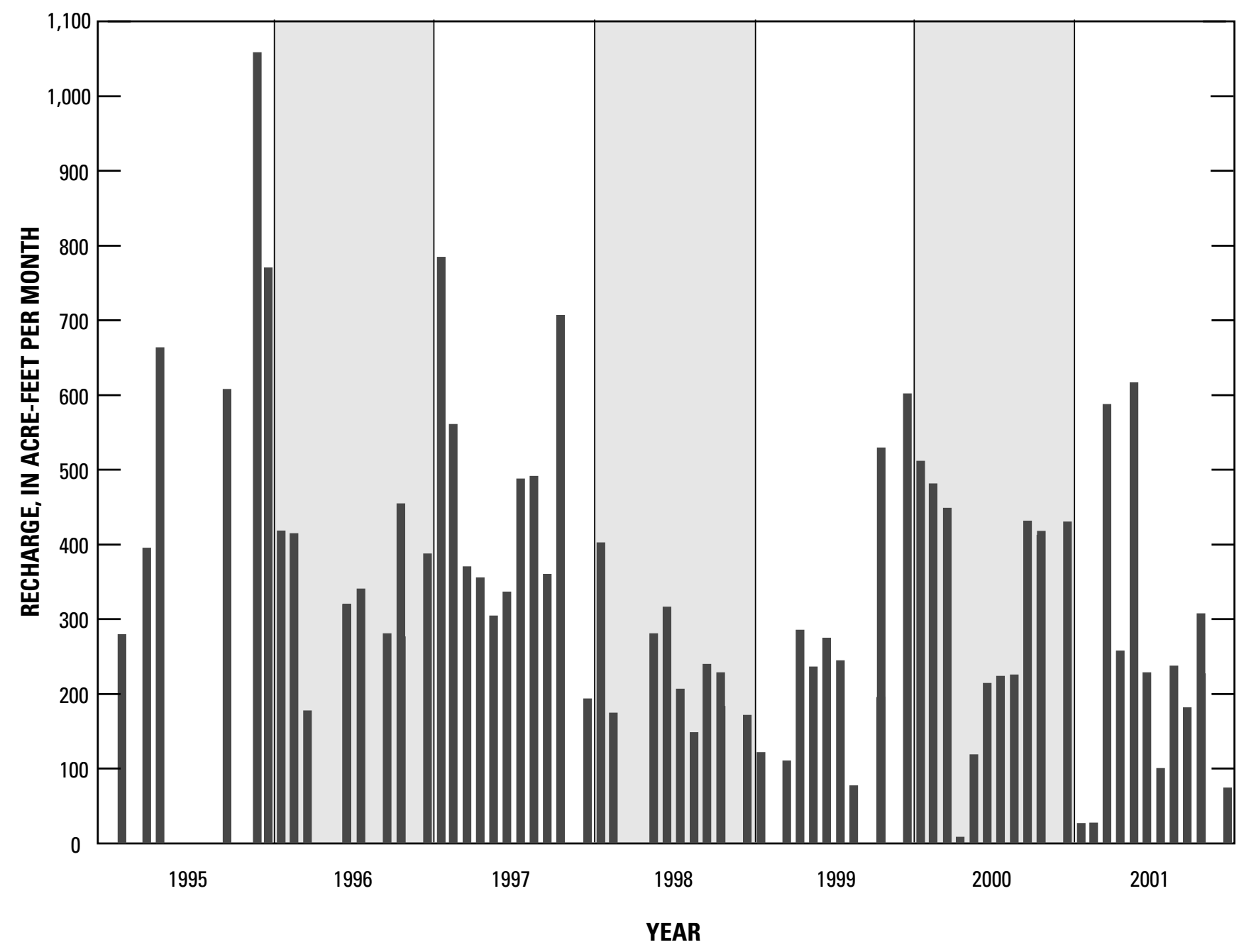

Figure 8. Total monthly artificial recharge, 1995-2001, Warren ground-water basin, San Bernardino County, California. 


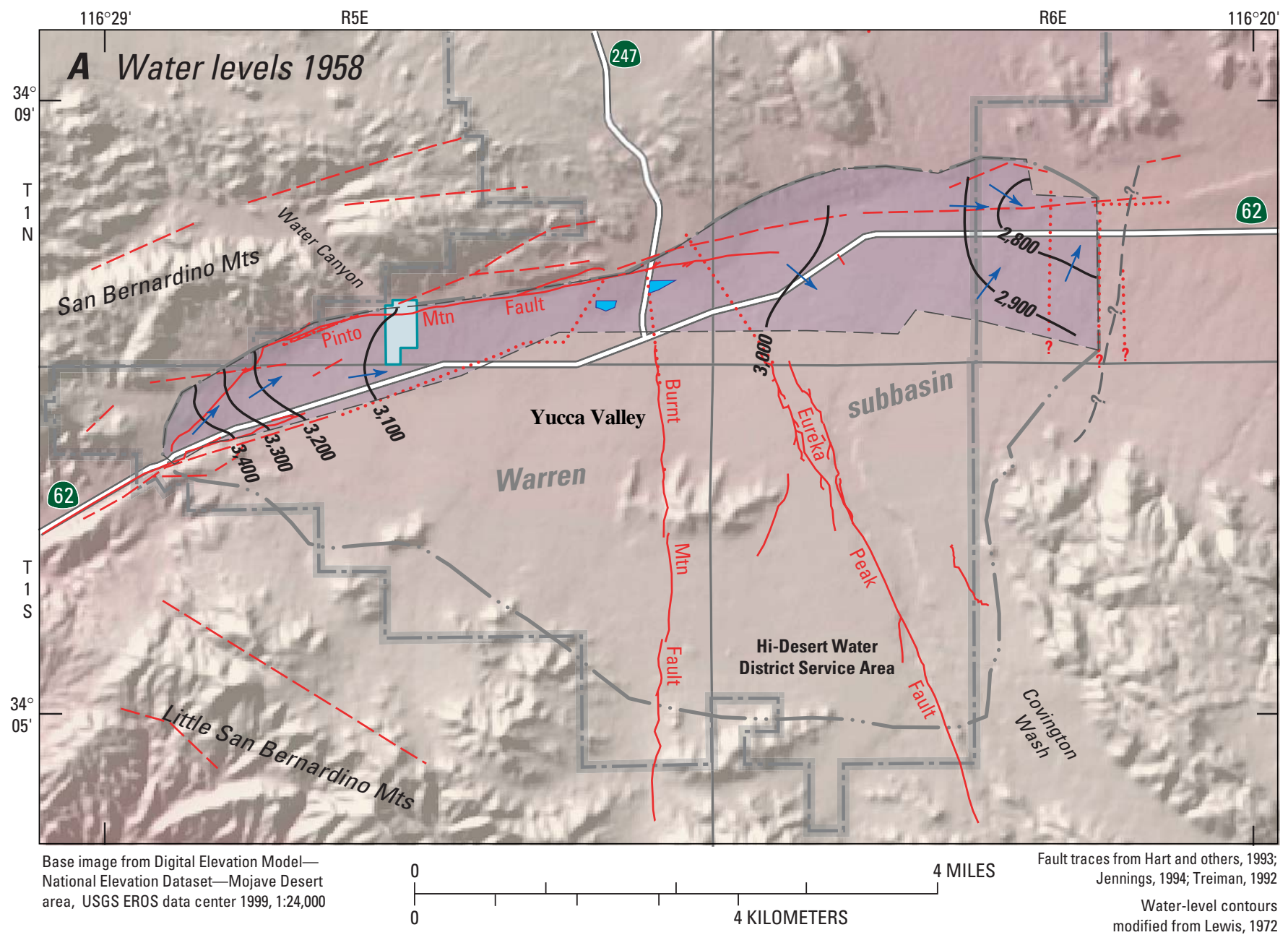

EXPLANATION
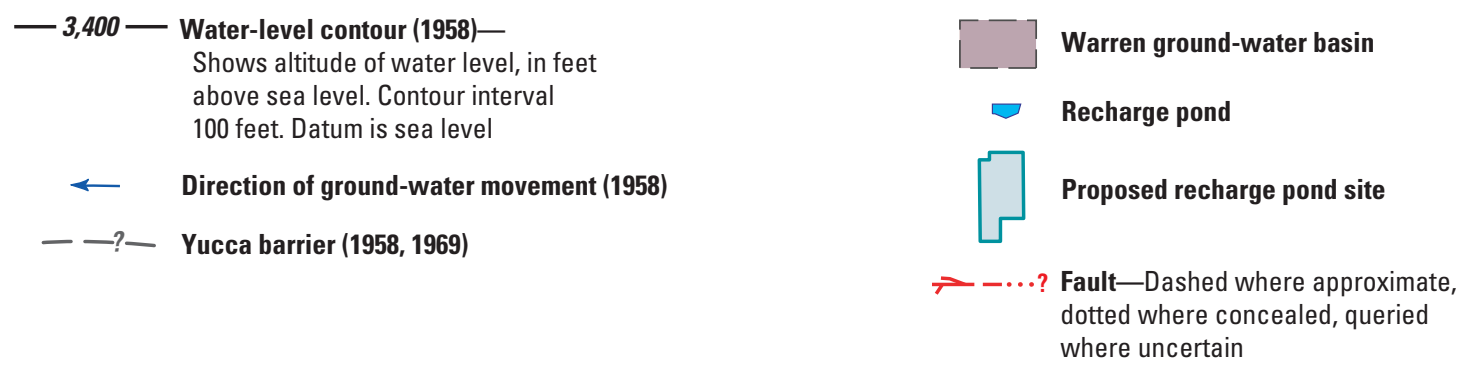

Figure 9. Water-level maps for $(A)$ 1958, $(B)$ 1969, (C) 1994, and (D) 1998, Warren ground-water basin, San Bernardino County, California. 


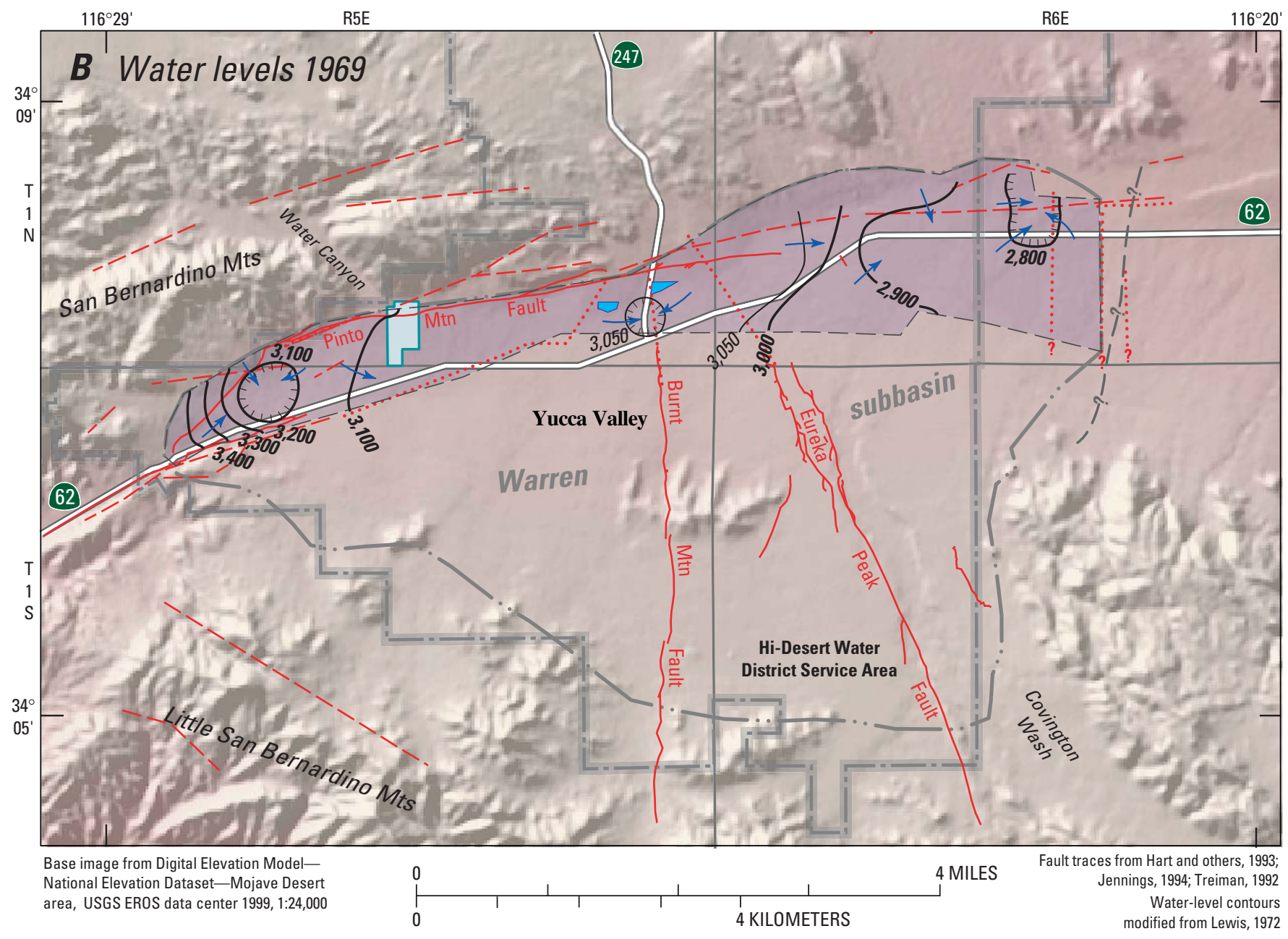

EXPLANATION

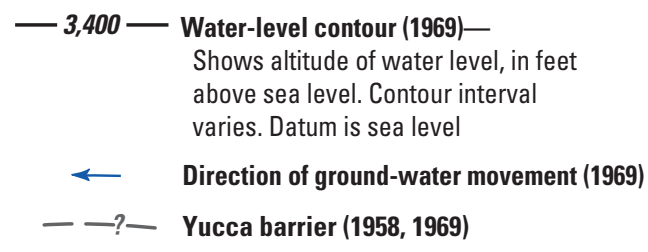

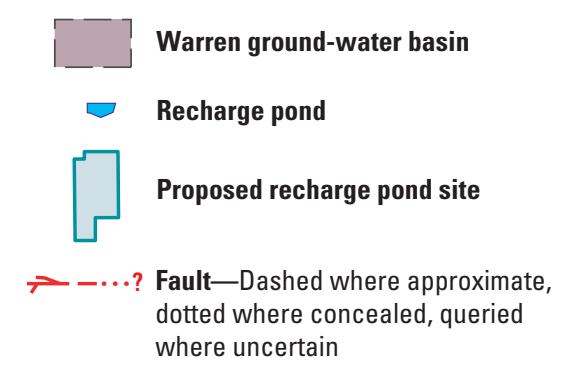

where uncertain

Figure 9-Continued. 


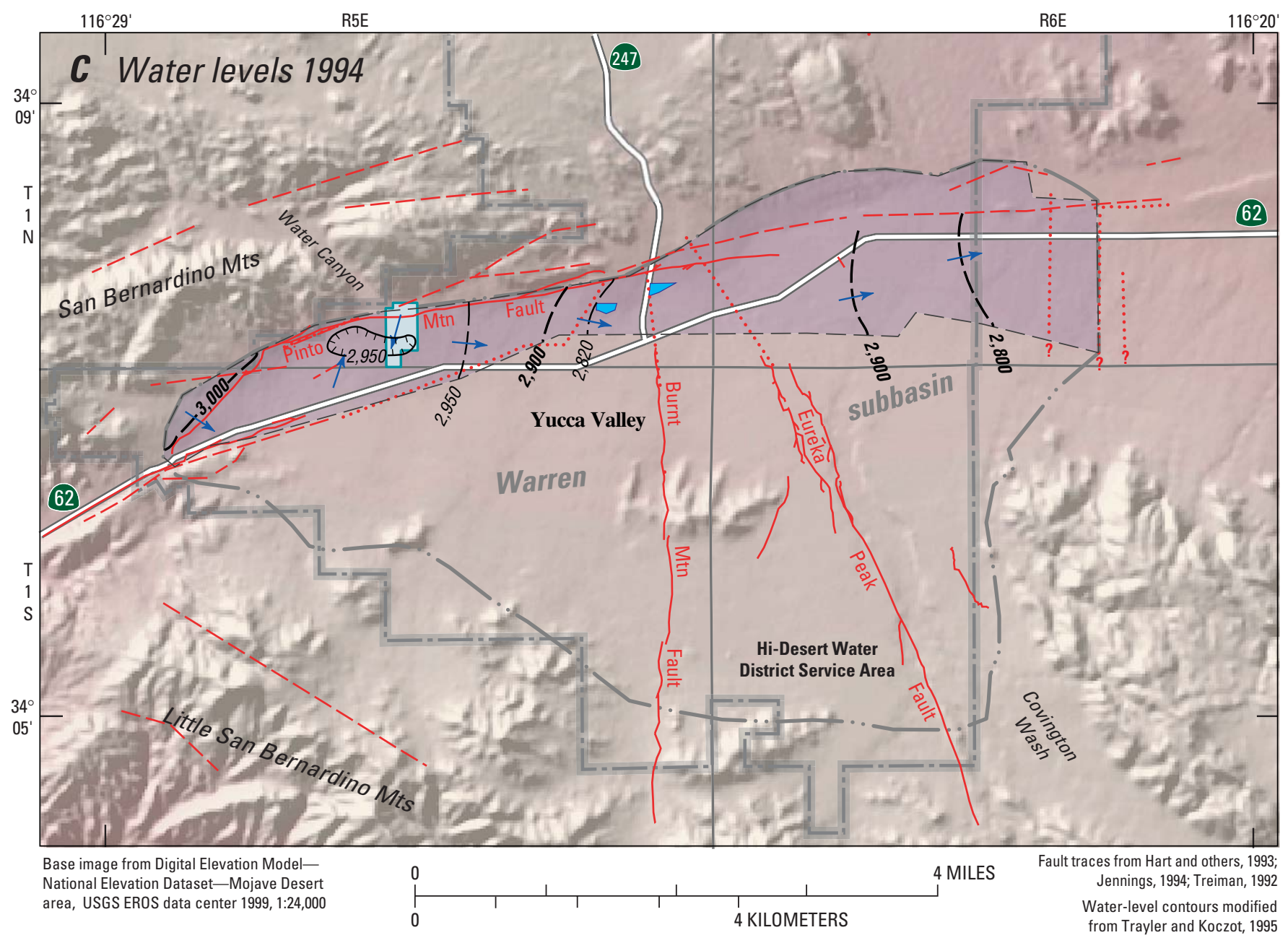

\section{EXPLANATION}

— 2,900 — Water-level contour (1994)—Shows altitude of water level, in feet above sea level. Dashed where approximate. Queried where uncertain. Contour interval varies. Datum is sea level

Direction of ground-water movement (1994)

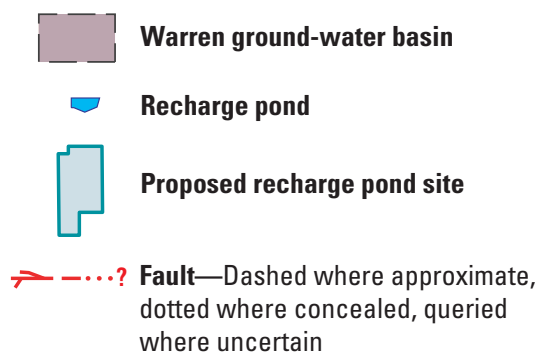

where uncertain

Figure 9-Continued. 


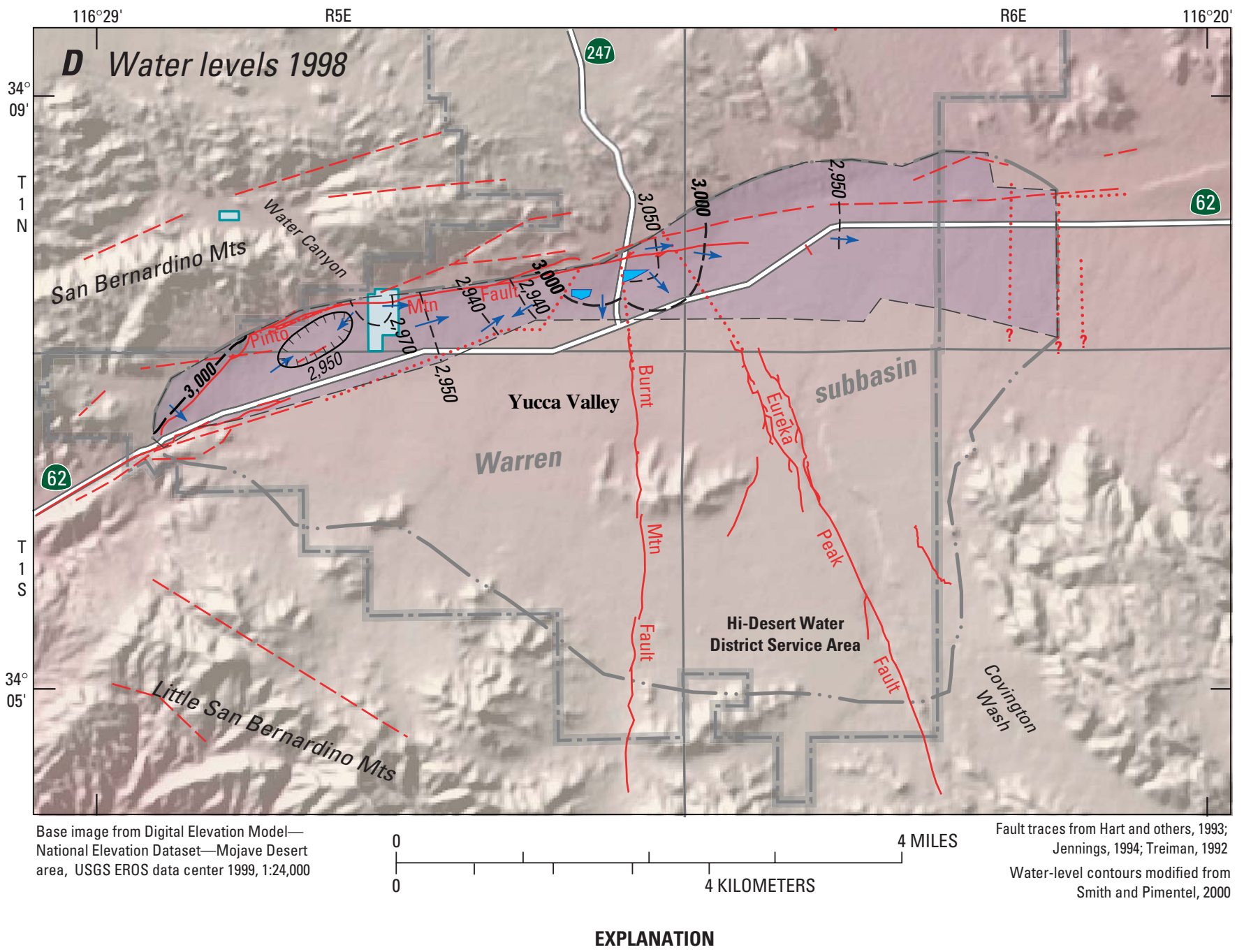

-3,000 — Water-level contour (1998)—Shows altitude of water level, in feet above sea level. Dashed where approximate. Queried where uncertain. Contour interval varies. Datum is sea level

Direction of ground-water movement (1998)

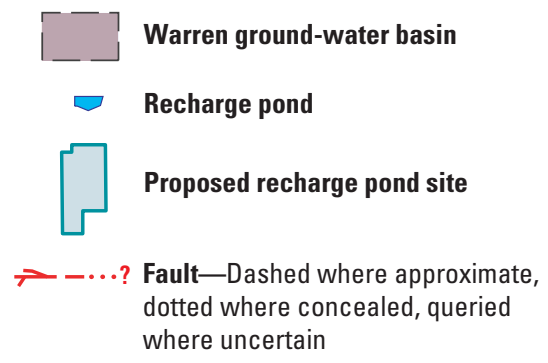

where uncertain

Figure 9-Continued. 
The 1969 ground-water levels (fig. 9B) represent conditions after 14 years of ground-water pumping (a cumulative volume of about 13,900 acre-ft) in the Warren ground-water basin. In 1969, there were local pumping depressions in the west (about a $50 \mathrm{ft}$ waterlevel decline near the golf course), midwest [about a $50 \mathrm{ft}$ water-level decline in well 1N/5E-36K1 (HDWD-1)], and east (about a $50 \mathrm{ft}$ water-level decline near well 1N/6E-28N1) hydrogeologic units that were not evident in the 1958 data. Ground-water levels ranged from about 3,400 to less than $3,100 \mathrm{ft}$ above sea level in the west hydrogeologic unit of the basin, from less than 3,100 to less than 3,050 ft above sea level in the midwest and mideast hydrogeologic units, and from about 3,050 to 2,800 ft above sea level in the northeast and east hydrogeologic units (igs. 1 and $\underline{9 B}$ ). In general, ground water flowed towards the east at an average hydraulic gradient of about $0.009 \mathrm{ft} / \mathrm{ft}$; however, near the pumping depressions, ground-water flow converged on these depressions.

The 1994 ground-water levels (fig. 9C) represent conditions after 39 years of ground-water pumping (a cumulative volume of about 64,000 acre-ft) in the Warren ground-water basin and prior to the artificial recharge of imported water. Ground-water data collected in 1994 indicate that ground-water levels declined about $70 \mathrm{ft}$ since 1958 to a low of about 2,930 $\mathrm{ft}$ above sea level in well 1N/5E-34P4 (10W) in the west hydrogeologic unit; about $300 \mathrm{ft}$ since 1958 to $2,807 \mathrm{ft}$ above sea level in well 1N/5E-36K2 (9E) in the midwest hydrogeologic unit; about $250 \mathrm{ft}$ since 1958 to $2,856 \mathrm{ft}$ above sea level in well $1 \mathrm{~N} / 5 \mathrm{E}-36 \mathrm{~K} 3$ (14E) in the mideast hydrogeologic unit; and about $30 \mathrm{ft}$ since 1958 to $2,919 \mathrm{ft}$ above sea level in well 1N/6E-29R3 (13E) in the northeast hydrogeologic unit. In addition, pumpage from water-supply wells in the midwest and mideast hydrogeologic units created a cone of depression centered on the Burnt Mountain fault.

The 1998 ground-water levels (fig. 9D) represent conditions after 43 years of ground-water pumping (a cumulative volume of about 73,000 acre-ft) in the Warren ground-water basin and after three years of artificial recharge of imported water (a cumulative volume of about 12,500 acre-ft). Ground-water data collected in 1998 indicate that ground-water levels had recovered about $20 \mathrm{ft}$ since 1994 to $2,950 \mathrm{ft}$ above sea level in well 1N/5E-34P4 (10W) in the west hydrogeologic unit; about $135 \mathrm{ft}$ since 1994 to $2,941 \mathrm{ft}$ above sea level in well 1N/5E-36K2 (9E) in the midwest hydrogeologic unit; about $190 \mathrm{ft}$ since 1994 to $3,044 \mathrm{ft}$ above sea level in well 1N/5E-36K3 (14E) in the mideast hydrogeologic unit; and about $7 \mathrm{ft}$ since 1994 to 2,926 ft above sea level in well 1N/6E-29R3 (13E) in the northeast hydrogeologic unit. In addition, a water-level mound had formed centered on the two recharge ponds.

The long-term hydrograph for wells 1N/5E-36K1 (HDWD-1) and 36K2 (9E), which are perforated in the upper, middle, and lower aquifers and located in the midwest hydrogeologic unit near recharge site 6 , indicates a decline in ground-water levels of about $300 \mathrm{ft}$ from the late 1940s to 1994 (fig. 10A). Water levels began to recover in November 1995, approximately nine months after recharge of imported water began in February 1995. By 2000, water levels had risen by as much as 250 feet in wells in the midwest hydrogeologic unit near site 6 (fig. 10A). The hydrographs for two wells located in the mideast hydrogeologic unit near recharge site 7 , $1 \mathrm{~N} / 5 \mathrm{E}-36 \mathrm{H} 2$ (18E) (perforated in the middle and lower aquifers) and $1 \mathrm{~N} / 5 \mathrm{E}-36 \mathrm{~K} 3$ (14E) (perforated in the lower aquifer), indicate that water levels began to recover between mid-1994 to early-1995 (fig. 10B). By 2000, water levels had risen by as much as $220 \mathrm{ft}$ in these wells near recharge site 7 (fig. 10B). Since artificial recharge began in the midwest and mideast hydrogeologic units, water levels have risen very little in the west, east, or northeast hydrogeologic units. The lack of water-level rise in these hydrogeologic units may be explained by the faults that separate the units, which act as barriers to ground-water flow, and (or) by the fact that there are no artificial-recharge ponds located in these units. 

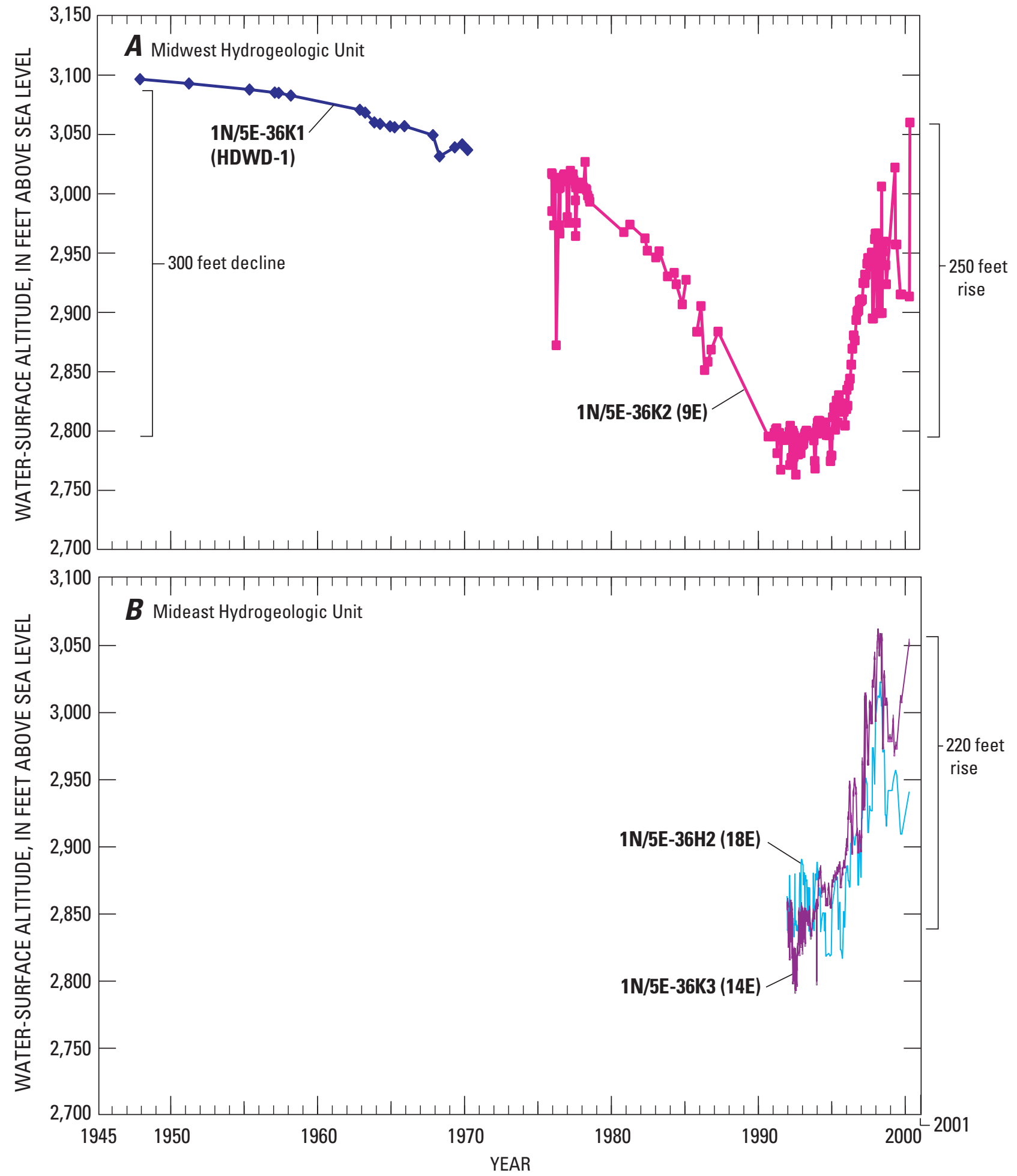

Figure 10. Water-level hydrographs for wells (A) 1N/5E-36K1 (HDWD-1) and 36K2 (HDWD-1) in the midwest hydrogeologic unit and (B) 1N/5E-36H2 (18E) and 36K3 (14E) in the mideast hydrogeologic unit, Warren ground-water basin, San Bernardino County, California. 


\section{NITRATE IN GROUND WATER}

Prior to the start of the artificial-recharge program, nitrate- $\mathrm{NO}_{3}$ concentrations throughout most of the ground-water basin were generally less than $10 \mathrm{mg} / \mathrm{L}$. After the start of the artificial-recharge program, $\mathrm{NO}_{3}$ concentrations increased to as high as $110 \mathrm{mg} / \mathrm{L}$ beneath recharge site 7 . The following sections will describe the areal distribution of $\mathrm{NO}_{3}$ prior to, and after, the start of the artificial-recharge program; list potential sources of $\mathrm{NO}_{3}$; and identify the $\mathrm{NO}_{3}$ sources through geochemical analyses (including the examination of general chemical characteristics, temporal changes in $\mathrm{NO}_{3}$, nitrate-to-chloride ratios, stable isotope analysis, nitrogen isotopes, dissolved organic carbon and fluorescence, and caffeine and pharmaceutical analyses).

\section{Areal Distribution of Nitrate}

To determine how the nitrate concentration in the Warren ground-water basin has changed since the start of the artificial recharge program, nitrate- $\mathrm{NO}_{3}$ concentration data collected between September 1991 and January 1995 (prior to the artificial-recharge program), 1998 (three years after the start of the artificial-recharge program), and in 2001 (six years after the start of the artificial-recharge program) were mapped (fig. 11). Many of the samples were collected from HDWD production wells, which have long perforated intervals; therefore, the sampled water is a mixture of waters from different water-bearing deposits that have different sources and, possibly, different water chemistries. The only depth-specific samples were collected from the multiple-well monitoring sites.

Distribution of Nitrates Prior to Artificial Recharge

Nitrate data collected between September 1991 and January 1995 reflect conditions prior to the start of the artificial recharge program. The $\mathrm{NO}_{3}$ concentrations in ground water ranged from 2.9 to $26 \mathrm{mg} / \mathrm{L}$ (fig. 11A). In the west hydrogeologic unit, $\mathrm{NO}_{3}$ concentrations were about $10 \mathrm{mg} / \mathrm{L}$ or less in wells near Water Canyon (a source of natural recharge to the basin) and represent native or naturally occurring $\mathrm{NO}_{3}$ concentrations in ground water in the Warren ground-water basin. The $\mathrm{NO}_{3}$ concentrations in wells $1 \mathrm{~N} / 5 \mathrm{E}-35 \mathrm{~K} 1(11 \mathrm{~W})$ and $35 \mathrm{P} 1(3 \mathrm{~W})$, farther east, were 11.5 and $15.5 \mathrm{mg} / \mathrm{L}$, respectively; these concentrations were slightly higher than background concentrations. In the midwest hydrogeologic unit, $\mathrm{NO}_{3}$ concentrations ranged from about 9 to about $20 \mathrm{mg} / \mathrm{L}$. In the mideast hydrogeologic unit, $\mathrm{NO}_{3}$ concentrations in all wells were less than $10 \mathrm{mg} / \mathrm{L}$. In the northeast and east hydrogeologic units, the $\mathrm{NO}_{3}$ concentration in wells 1N/6E-31C1 (5E), 29R3 (13E), and 29J3 (11E) ranged from 16 to $26 \mathrm{mg} / \mathrm{L}$.

Distribution of Nitrates After Artificial Recharge Started

\section{Conditions}

Nitrate data were collected from 18 wells between March and April 1998 and reflect conditions three years after the start of the artificial recharge program. Thirteen of the 18 wells had been sampled during 1991-95. The $\mathrm{NO}_{3}$ concentrations in ground water ranged from about $5 \mathrm{mg} / \mathrm{L}$ to about $110 \mathrm{mg} / \mathrm{L}$ (fig. 11B ). In the west hydrogeologic unit, three wells were sampled and the $\mathrm{NO}_{3}$ concentrations in these wells were about $20 \mathrm{mg} / \mathrm{L}$. In the midwest and mideast hydrogeologic units, the $\mathrm{NO}_{3}$ concentrations were as high as $110 \mathrm{mg} / \mathrm{L}$; six wells had $\mathrm{NO}_{3}$ concentrations greater than the MCL of $44 \mathrm{mg} / \mathrm{L}$. In the northeast and east hydrogeologic units, only one well

[1N/6E-31C1 (5E)] was sampled and this well had a $\mathrm{NO}_{3}$ concentration of $10.3 \mathrm{mg} / \mathrm{L}$. 


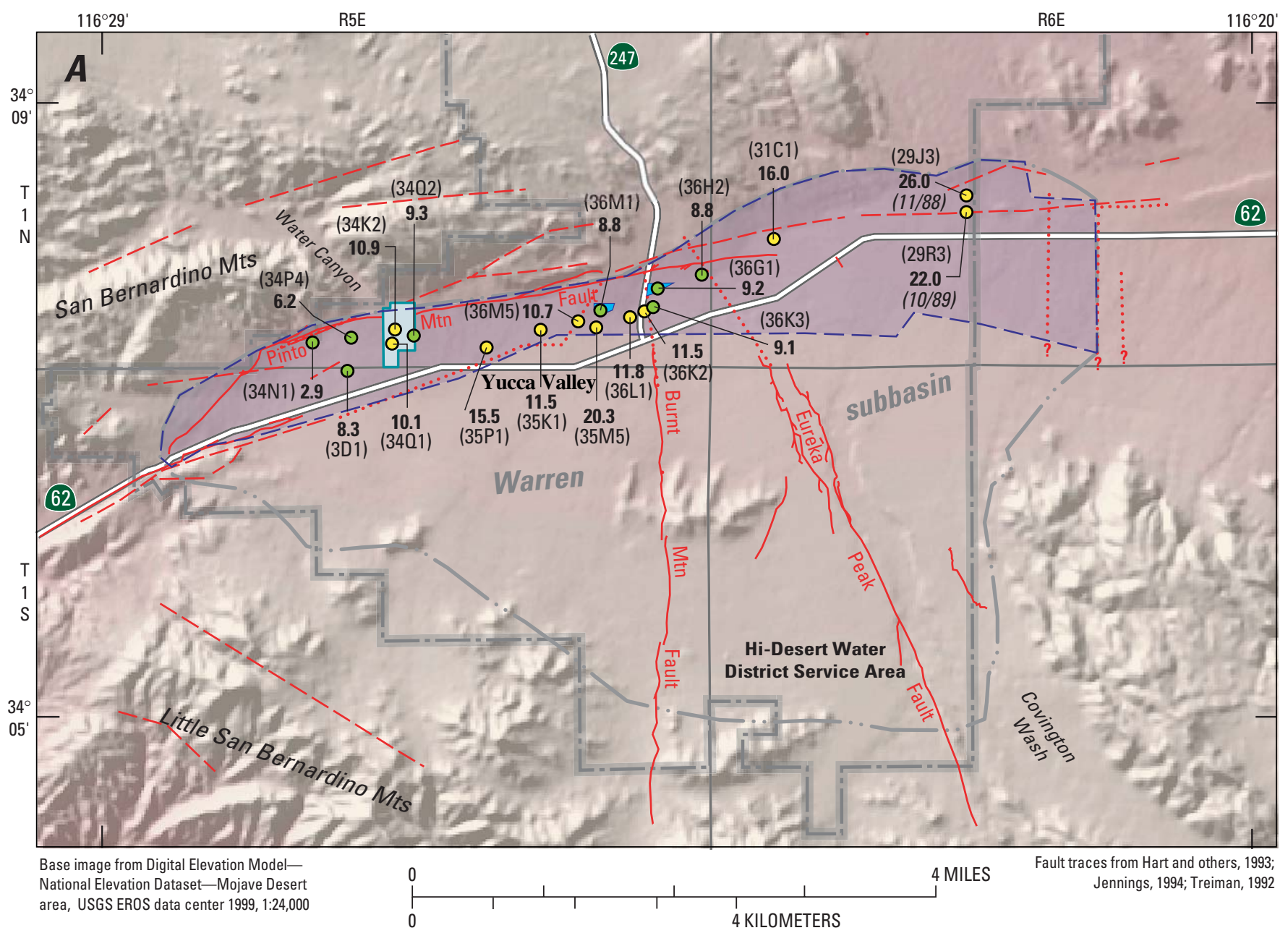

EXPLANATION
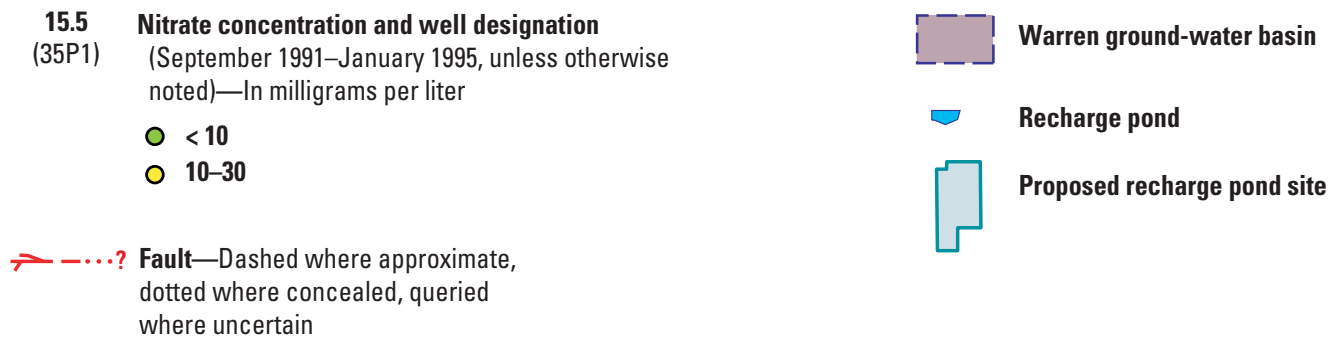

where uncertain

Figure 11. Areal distribution of nitrate prior to artificial recharge program during $(A)$ September 1991 to January 1995, $(B)$ 1998, and (C) 2001, Warren groundwater basin, San Bernardino County, California. 


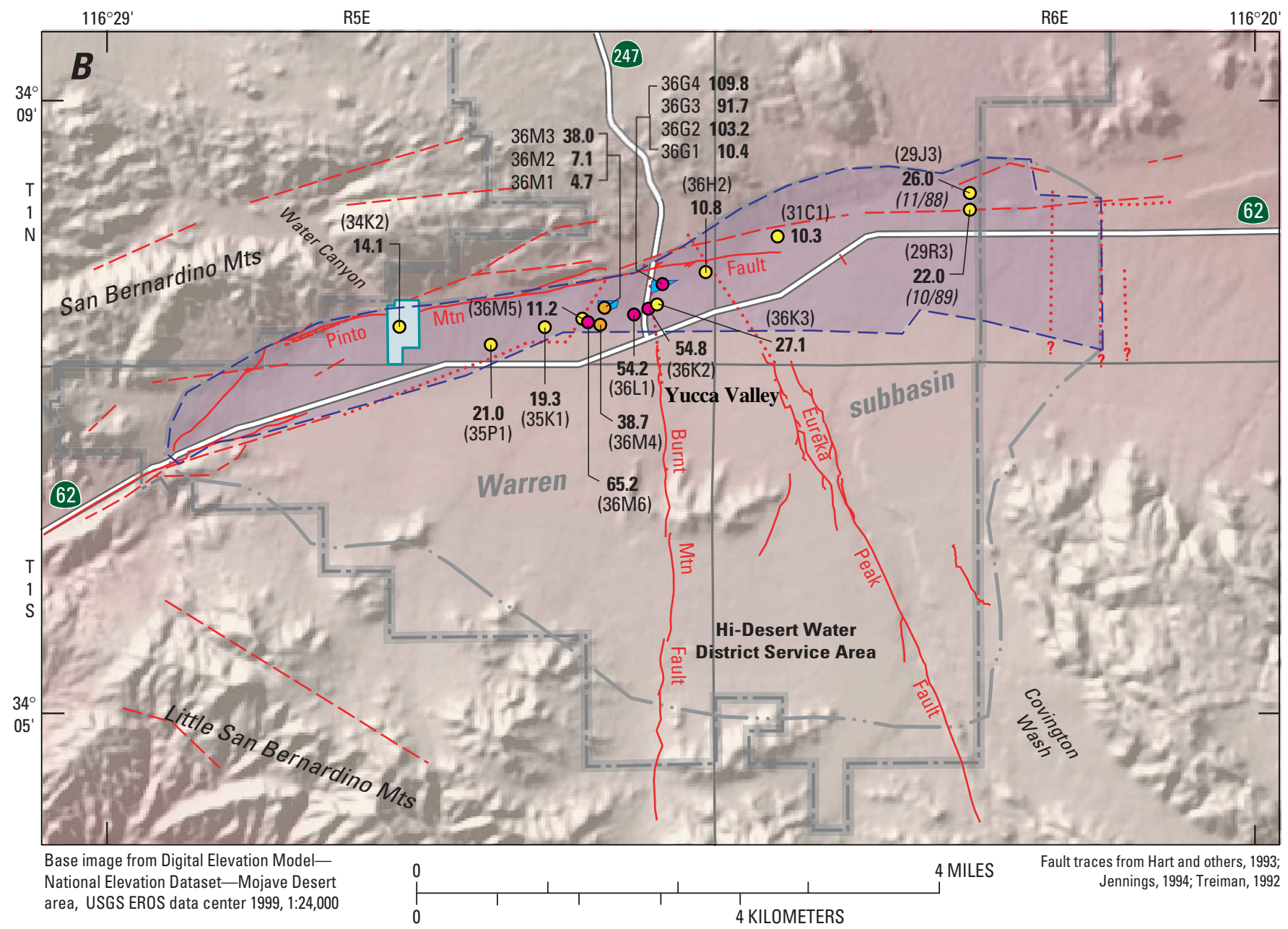

\section{EXPLANATION}

$21.0 \quad$ Nitrate concentration and well designation

(35P1) (March-April 1998, unless otherwise noted)—In milligrams per liter
○ $10-30$
O $31-45$
$0>45$

-...? Fault-Dashed where approximate, dotted where concealed, queried where uncertain

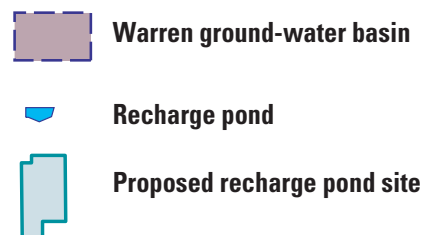

Figure 11.-Continued. 


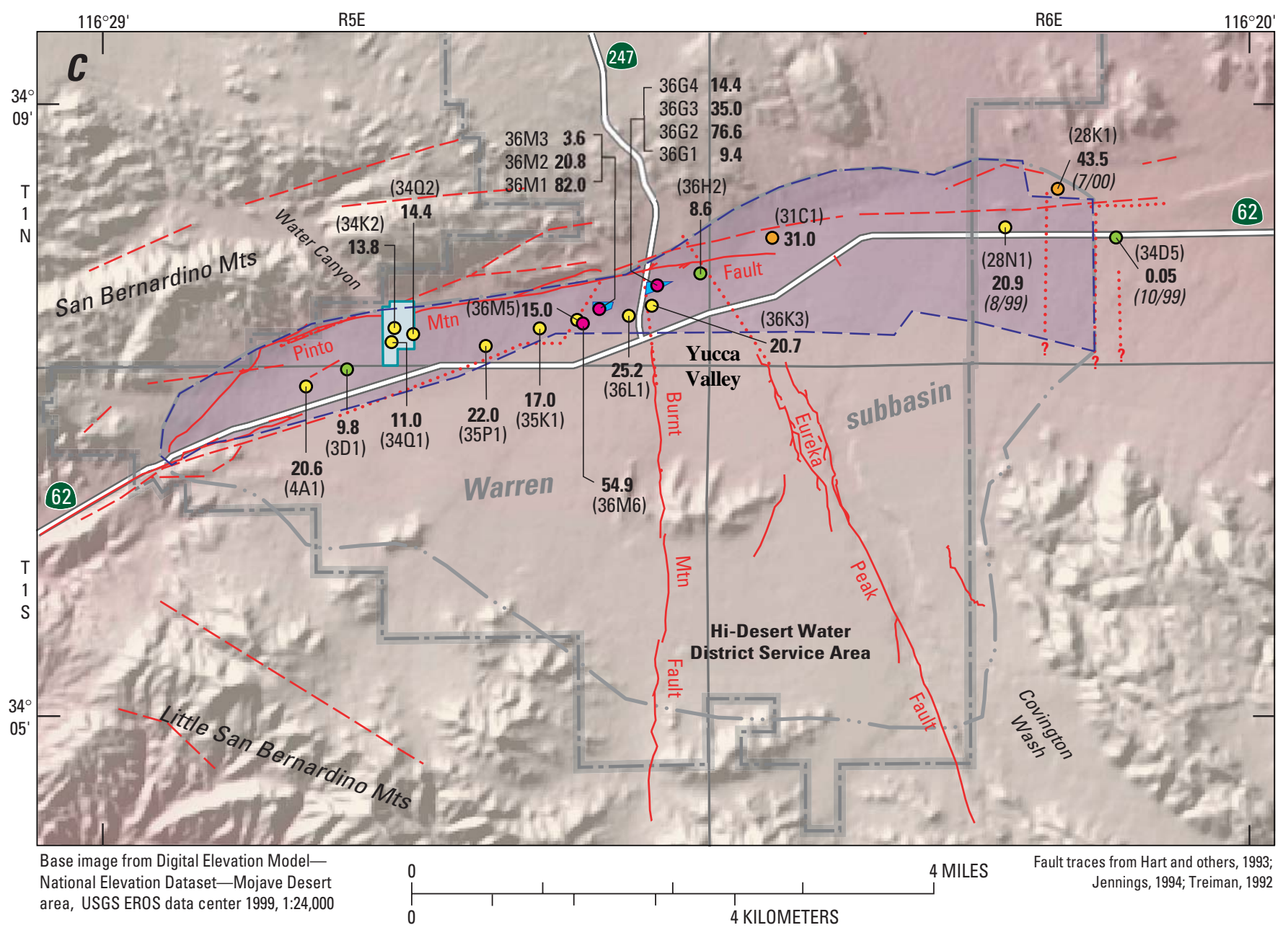

\section{EXPLANATION}

$20.6 \quad$ Nitrate concentration and well designation

(4A1) (July-August 2001, unless otherwise noted)—-In milligrams per liter

$0<10$

O $10-30$

○ 31-45

$0>45$

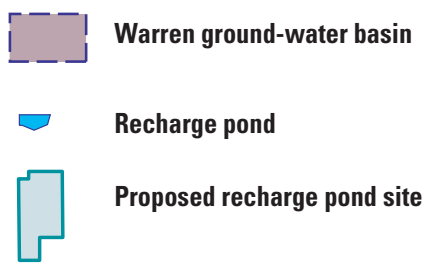
- -...? Fault-Dashed where approximate, dotted where concealed, queried where uncertain

Figure 11.-Continued. 


\section{Conditions}

Nitrate data were collected from 20 wells in 2001 and reflect conditions six years after the start of the artificial recharge program. Sixteen of the 20 wells had been sampled during 1998. The $\mathrm{NO}_{3}$ concentrations in ground water ranged from about 4 to about $82 \mathrm{mg} / \mathrm{L}$ (fig. 11C). In the west hydrogeologic unit, only three wells were sampled in both 1998 and 2001 and in these wells $\mathrm{NO}_{3}$ concentrations were about the same as 1998 conditions. In the midwest and mideast hydrogeologic units, all the $\mathrm{NO}_{3}$ concentrations declined from 1998 levels with the exception of three wells [1N/5E-36M5 (16E), 36M1 (YV2-590), and 36M2 (YV2-390)] that increased in $\mathrm{NO}_{3}$ concentrations; however, only three wells were above the MCL of $44 \mathrm{mg} / \mathrm{L}$. In the northeast and east hydrogeologic units, the $\mathrm{NO}_{3}$ concentration in well $1 \mathrm{~N} / 6 \mathrm{E}-31 \mathrm{C} 1$ (5E) increased to $31 \mathrm{mg} / \mathrm{L}$ in 2001 from $10.3 \mathrm{mg} / \mathrm{L}$ in 1998 . The increase in $\mathrm{NO}_{3}$ concentration in this well does not appear to be caused by the migration of the high $\mathrm{NO}_{3}$-concentration water from the mideast hydrogeologic unit because well 1N/5E36H2 (18E) (located between site 7 and well 31C1) produced water with a low $\mathrm{NO}_{3}$ concentration of about $9 \mathrm{mg} / \mathrm{L}$.

\section{Potential Sources of Nitrate}

Potential sources of $\mathrm{NO}_{3}$ in the Warren groundwater basin include imported water from the SWP, the leaching of natural soil $\mathrm{NO}_{3}$ by recharged SWP water, septage, and $\mathrm{NO}_{3}$-rich irrigation-return flow. To evaluate these possible sources, samples of SWP water, soils within the basin, and septage were collected and compared with ground-water-quality samples collected from wells in the basin. Samples of irrigation-return flow were not collected; therefore, published estimates were used for $\mathrm{NO}_{3}$ concentrations of irrigation-return flow. The $\mathrm{NO}_{3}$ concentration of imported SWP water is low (1-4 mg/L as $\left.\mathrm{NO}_{3}\right)$ and was eliminated as a direct source of the high- $\mathrm{NO}_{3}$ concentrations in ground water.

\section{Natural Soil Nitrate}

In a previously dry, undeveloped area, $\mathrm{NO}_{3}$ concentrations in the unsaturated zone can be high and the subsequent infiltration of water through the unsaturated zone can leach natural-soil $\mathrm{NO}_{3}$ thereby providing a significant source of $\mathrm{NO}_{3}$ to the groundwater system (Bouwer, 1978). Umari and others (1995) examined soil cores collected beneath undeveloped sites near Victorville, California (Mojave Desert site about 50 mi northwest of the study area), and found that concentrations of $\mathrm{NO}_{3}$ and chloride were as high as $1,196 \mathrm{mg} / \mathrm{L}$ and $6,000 \mathrm{mg} / \mathrm{L}$, respectively. Densmore and Böhlke (2000) found that artificial leaching of natural-soil $\mathrm{NO}_{3}$ was the source of locally high $\mathrm{NO}_{3}$ concentrations (in excess of $115 \mathrm{mg} / \mathrm{L}$ ) in ground water beneath Bicycle Basin, California (Mojave Desert site about $80 \mathrm{mi}$ north of the study area).

Soil samples were collected in 1998 and 1999 from 1-4.5 ft depths at four sites in the midwest and mideast hydrogeologic units (soil-sampling sites 3, 8, 10, and 15 in fig. 4) to determine the concentration of leachable soil nitrate as nitrogen $\left(\mathrm{NO}_{3}-\mathrm{N}\right)$ (fig. 12; table 3). Total-nitrogen concentrations in the dried soil samples ranged from 116 to $189 \mathrm{mg} / \mathrm{kg}$ and the leachable $\mathrm{NO}_{3}-\mathrm{N}$ ranged from 2 to $11 \mathrm{mg} / \mathrm{kg}$ (table 3). The highest total-nitrogen concentrations were in the mideast hydrogeologic unit (sample site 10). The concentrations measured in these soils show that leachable $\mathrm{NO}_{3}-\mathrm{N}$ accounted for only 1 to 9 percent of the total nitrogen in the soils. Assuming a porosity of 0.30 and a particle density of $2.65 \mathrm{gm} / \mathrm{cm}^{3}$, the leachable $\mathrm{NO}_{3}-\mathrm{N}$ ranged from about 4 to $20 \mathrm{mg} / \mathrm{L}$ (or about 20 to $90 \mathrm{mg} / \mathrm{L}$ as $\mathrm{NO}_{3}$ ).

\section{Nitrates from Septic Tanks}

Septic tanks are the primary method of wastewater disposal in the Warren ground-water basin; therefore, septage is a possible source of $\mathrm{NO}_{3}$ to the ground water. Bouwer (1978) reported that nitrogen concentrations in septage can range from 40 to $80 \mathrm{mg} / \mathrm{L}$; mostly in the form of ammonium. If all of the nitrogen was converted to $\mathrm{NO}_{3}$, then concentrations could range from 177 to $354 \mathrm{mg} / \mathrm{L}$. A sample of septage collected from a residential septic tank in the midwest hydrogeologic unit had a $\mathrm{NO}_{3}$ concentration of about $154 \mathrm{mg} / \mathrm{L}$. Samples of septage from five different septic tanks in Victorville, California, had $\mathrm{NO}_{3}$ concentrations ranging from 97 to $280 \mathrm{mg} / \mathrm{L}$ and averaged $208 \mathrm{mg} / \mathrm{L}$ (Umari and others, 1995). 


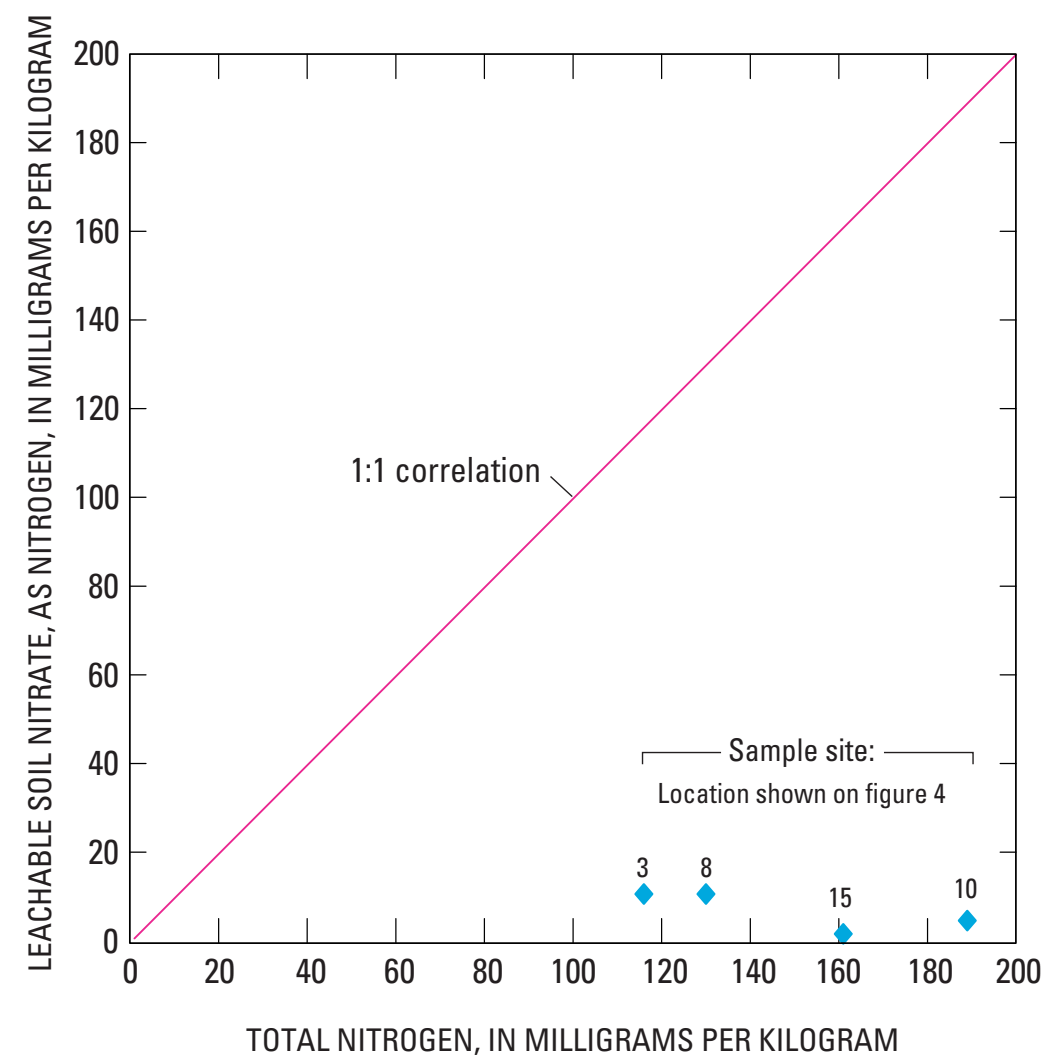

Figure 12. Comparison of total nitrogen in whole soils with nitrate concentrations in soil leachate, Warren ground-water basin, San Bernardino County, California. 
Table 3. Soil nitrate data for soil samples from Warren ground-water basin, California

[per mil, parts per thousand; mg/kg, milligram per kilogram; NO3, nitrate; —, no data]

\begin{tabular}{|c|c|c|c|c|c|c|c|}
\hline \multirow[b]{2}{*}{$\begin{array}{c}\text { Sample } \\
\text { name }\end{array}$} & \multirow[b]{2}{*}{ Year } & \multirow[b]{2}{*}{ Depth } & \multicolumn{2}{|c|}{ Whole soils } & \multicolumn{2}{|c|}{ Leachates } & \multirow{2}{*}{$\begin{array}{l}\text { Percent of } \\
\text { leachable } \\
\mathrm{NO}_{3} \\
\text { total nitrogen }\end{array}$} \\
\hline & & & $\begin{array}{l}\text { Total-nitrogen } \\
\text { (mg/kg) }\end{array}$ & $\begin{array}{c}\delta^{15} \mathrm{~N} \text { of total } \\
\text { nitrogen } \\
\text { (per mil) }\end{array}$ & $\begin{array}{c}\text { Leachable } \mathrm{NO}_{3} \\
\text { as nitrogen } \\
(\mathrm{mg} / \mathrm{kg})\end{array}$ & $\begin{array}{c}\delta^{15} \mathrm{~N} \text { of leachable } \\
\mathrm{NO}_{3} \text { as nitrogen } \\
\text { (per mil) }\end{array}$ & \\
\hline Site 3 & 1998 & 4.5 & 116 & 7.0 & 11 & 5.73 & 9 \\
\hline Site 8 & 1998 & 3.5 & 130 & 8.0 & 11 & 6.70 & 8 \\
\hline Site 10 & 1998 & 1.0 & 189 & 7.8 & 5 & 5.52 & 3 \\
\hline Site 15 & 1999 & - & 161 & 6.4 & 2 & 3.60 & 1 \\
\hline
\end{tabular}


Nitrates from Irrigation-Return Flow

The primary source of irrigation-return flow in the Warren ground-water basin is the golf course located in the western part of the west hydrogeologic unit. Golf courses are commonly treated with $\mathrm{NO}_{3}-$ based fertilizer to improve the quality of the playing surface. Samples of irrigation-return flow were not collected for analysis; however, Bouwer (1978) reported that $\mathrm{NO}_{3}$ concentrations in ground water collected beneath irrigated fields in the western United States can range from 66 to $220 \mathrm{mg} / \mathrm{L}$. The $\mathrm{NO}_{3}$ concentration of the return flow from the golf course is probably high; however, the water levels (fig. 9D) and the areal distribution of $\mathrm{NO}_{3}$ concentrations (fig. $11 B$ ) indicate that irrigation-return flow from the golf course could not be the source of high- $\mathrm{NO}_{3}$ water present in the midwest and mideast hydrogeologic units in 1998.

\section{Identification of Nitrate Source}

To identify the source of increasing $\mathrm{NO}_{3}$ concentrations, water-quality samples were collected from 30 wells and the two multiple-well monitoring sites in the Warren ground-water basin from December 1992-August 2001. This was done by analyzing the general chemical characteristics, temporal changes in $\mathrm{NO}_{3}$ concentrations, nitrate-to-chloride ratios, stable isotopes of oxygen and hydrogen, nitrogen isotopes, fluorescence, dissolved-organic carbon (DOC), caffeine, and pharmaceuticals. USGS data can be found at http://ca.water.usgs.gov/ca/nwis/qw. Data collected as part of this study were supplemented with data collected by HDWD and MWA.

\section{General Chemical Characteristics}

Ground-water quality data were plotted to determine how the water type changed after the artificial-recharge program started. Figure 13 shows the analyses of samples from wells collected before recharge began in February 1995 and analyses of samples that had the highest recorded $\mathrm{NO}_{3}$ concentrations from these same wells after February 1995. Figure 13 also shows the average of four imported SWP water samples and a septage sample.
Samples of native ground water, collected from wells in the Warren ground-water basin before the start of the artificial-recharge program in February 1995, plot in the lower left portion of the diagrams indicating that the water from these wells is a calcium

$(\mathrm{Ca})$ /sodium (Na)-bicarbonate $\left(\mathrm{HCO}_{3}\right)$ water (fig. 13) . The sample average of imported water plots in the upper right portion of the diagram indicating that the imported-water samples were enriched in $\mathrm{Cl}$ and depleted in $\mathrm{HCO}_{3}$ relative to native ground water. The septage sample plots in the lower portion of the diagram and is similar to samples collected from production wells.

In general, the ground-water samples that have the highest recorded $\mathrm{NO}_{3}$ concentrations in the west hydrogeologic unit collected after the start of the artificial recharge program plot near the samples collected prior to the artificial recharge program, indicating mixing with imported water had not occurred (fig. 13A). However, samples collected from wells $1 \mathrm{~N} / 5 \mathrm{E}-35 \mathrm{P} 1$ (3W) and 1N/5E-35K1 (11W) in the eastern part of the west hydrogeologic unit (fig. 1) had an increase in $\mathrm{Cl}$ and a decrease in $\mathrm{HCO}_{3}$ indicating that mixing with imported water had begun (fig. 13A).

In general, the ground-water samples that had the highest recorded $\mathrm{NO}_{3}$ concentrations in the midwest and mideast hydrogeologic units collected after the start of the artificial recharge program plot near imported water, indicating mixing had occurred between imported water and native ground water (figs. 13B and $\underline{C}$ ). The sample collected from well $1 \mathrm{~N} / 5 \mathrm{E}-36 \mathrm{M} 5$ (16E), perforated in the middle and deep aquifers in the midwest hydrogeologic unit, plots on the lower half of the diagram; however, this sample showed increases in $\mathrm{Na}$ and $\mathrm{Cl}$ and decreases in $\mathrm{HCO}_{3}$, indicating that mixing with imported water had begun (fig. 13B). Samples collected after February 1995 from wells perforated in the lower aquifer [1N/5E-36G1 (YV1-570) and 1N/5E-36H2 (18E)] in the mideast hydrogeologic unit plot on the lower half of the diagram near the native ground-water samples, indicating that mixing with imported water had not yet occurred in these wells (fig. 13C). 

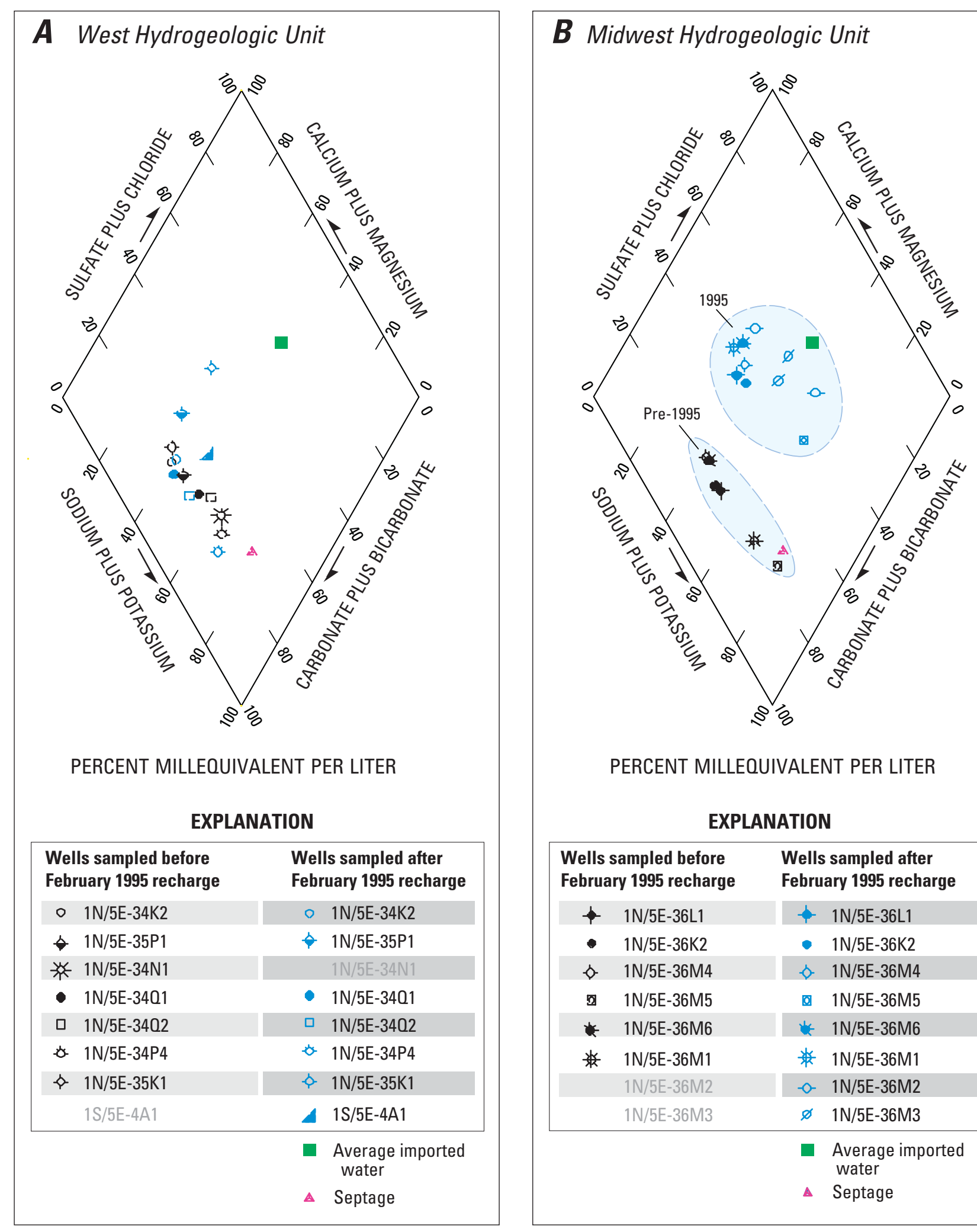

\section{PERCENT MILLEQUIVALENT PER LITER}

\section{EXPLANATION}

\begin{tabular}{|c|c|}
\hline $\begin{array}{l}\text { Wells sampled before } \\
\text { February } 1995 \text { recharge }\end{array}$ & $\begin{array}{l}\text { Wells sampled after } \\
\text { February } 1995 \text { recharge }\end{array}$ \\
\hline$\uparrow 1 \mathrm{~N} / 5 \mathrm{E}-36 \mathrm{~L} 1$ & $+1 \mathrm{~N} / 5 \mathrm{E}-36 \mathrm{~L} 1$ \\
\hline - $1 \mathrm{~N} / 5 \mathrm{E}-36 \mathrm{~K} 2$ & - $1 \mathrm{~N} / 5 \mathrm{E}-36 \mathrm{~K} 2$ \\
\hline ه. $1 \mathrm{~N} / 5 \mathrm{E}-36 \mathrm{M} 4$ & b. $1 N / 5 E-36 M 4$ \\
\hline . $1 \mathrm{~N} / 5 \mathrm{E}-36 \mathrm{M} 5$ & 1N/5E-36M5 \\
\hline 1N/5E-36M6 & * $1 \mathrm{~N} / 5 \mathrm{E}-36 \mathrm{M} 6$ \\
\hline 1N/5E-36M1 & 1N/5E-36M1 \\
\hline 1N/5E-36M2 & - - 1N/5E-36M2 \\
\hline 1N/5E-36M3 & $\varnothing \quad 1 N / 5 E-36 M 3$ \\
\hline & $\begin{array}{l}\text { Average imported } \\
\text { water } \\
\text { Septaqe }\end{array}$ \\
\hline
\end{tabular}

Figure 13. Water-quality diagrams of selected ground-water samples for the $(A)$ west, $(B)$ midwest, $(C)$ mideast, and $(D)$ east and northeast hydrogeologic units, Warren ground-water basin, San Bernardino County, California. 

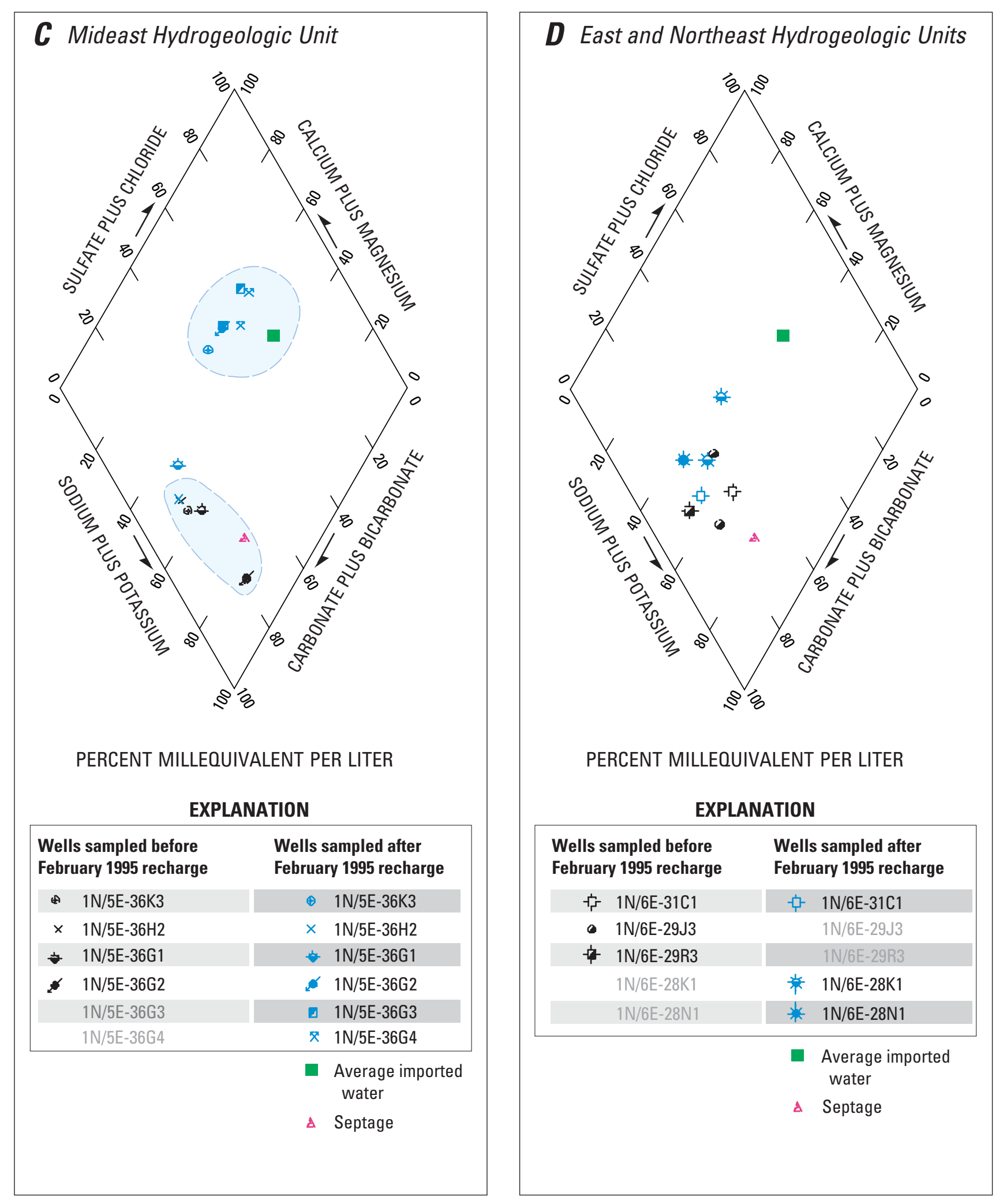

Figure 13.-Continued. 
In general, the ground-water samples in the east and northeast hydrogeologic units collected after the start of the artificial recharge program plot in the lower half of the diagram near the native ground-water samples (fig. 13D). Only well 1N/6E-31C1 (5E) was sampled before and after the start of the artificial recharge program. The sample collected after the start of the artificial recharge program from well

$1 \mathrm{~N} / 6 \mathrm{E}-31 \mathrm{C} 1$ (5E) plots near the sample collected prior to the start of the artificial recharge program, indicating mixing with imported water had not occurred (fig. 13D).

Although many ground-water samples collected after the start of the artificial recharge program indicate that mixing with imported water had occurred, the $\mathrm{NO}_{3}$ concentrations in the ground water (greater than 44 $\mathrm{mg} / \mathrm{L}$ ) were much greater than those in imported water (1-4 mg/L). Therefore, the mixing with imported water alone does not explain the source of the high- $\mathrm{NO}_{3}$ concentrations.

\section{Temporal Changes in Nitrate Concentration}

\section{Hi-Desert Water District Production Wells}

Available $\mathrm{NO}_{3}$ data collected prior to 1985 for the HDWD production wells indicate that native ground water in the Warren ground-water basin generally had $\mathrm{NO}_{3}$ concentrations less than $10 \mathrm{mg} / \mathrm{L}$ (fig. 14, table 4) at the end of the report). However, by the late 1980s, while water levels were still declining, the $\mathrm{NO}_{3}$ concentrations in samples from some wells perforated in the alluvial aquifer [1N/5E-35P1 (3W), 36L1 (7E), 36M4 (12E), 36M6 (17E), 1N/6E$31 \mathrm{C} 1(5 \mathrm{E})]$ started to increase and by 1994 were near $20 \mathrm{mg} / \mathrm{L}$.

The $\mathrm{NO}_{3}$ concentrations in samples from wells $1 \mathrm{~N} / 5 \mathrm{E}-35 \mathrm{~K} 1(11 \mathrm{~W})$ and $35 \mathrm{P} 1(3 \mathrm{~W})$ in the west hydrogeologic unit increased from $10 \mathrm{mg} / \mathrm{L}$ in 1994 to more than $30 \mathrm{mg} / \mathrm{L}$ in 1999 . These wells are in the eastern part of the west hydrogeologic unit and are within $5,000 \mathrm{ft}$ of recharge site 6 . The $\mathrm{NO}_{3}$ concentrations in these wells have since decreased to less than $25 \mathrm{mg} / \mathrm{L}$ in 2001 . The $\mathrm{NO}_{3}$ concentrations in the other wells in the west hydrogeologic unit remained relatively constant at about $10 \mathrm{mg} / \mathrm{L}$ (fig. 14A).

After the artificial recharge program started in 1995, nitrate concentrations increased rapidly in ground-water samples primarily from the midwest and mideast hydrogeologic units and, in some cases, exceeded the USEPA MCL for $\mathrm{NO}_{3}$ of $44 \mathrm{mg} / \mathrm{L}$. The $\mathrm{NO}_{3}$ concentrations started to decrease as early as 1998 in the midwest and mideast hydrogeologic units (figs. 14B and $\underline{C}$ ); however, as of 2001 there were two HDWD production wells [1N/5E-36M4 (12E) and $36 \mathrm{M} 6$ (17E)] that had $\mathrm{NO}_{3}$ concentrations above the MCL.

The $\mathrm{NO}_{3}$ concentrations in samples from wells 1N/5E-36K2 (9E), 36L1 (7E), 36M4 (12E), and 36M6 (17E) in the midwest hydrogeologic unit increased from about $15 \mathrm{mg} / \mathrm{L}$ in 1994 to more than $40 \mathrm{mg} / \mathrm{L}$ in 1998 (fig. 14B). Note that all of these wells have perforations in the middle and, in some cases, upper aquifers (fig. 6). The highest $\mathrm{NO}_{3}$ concentration of 95 $\mathrm{mg} / \mathrm{L}$ was observed in samples from well $36 \mathrm{~L} 1$ in 1997, which has the longest perforated interval in the upper aquifer in the midwest hydrogeologic unit. With the exception of well 1N/5E-36M5 (16E), which is perforated from 920 to $1,450 \mathrm{ft}$ below land surface (perforated in the lower and deep aquifers), the timing of the increase in measured $\mathrm{NO}_{3}$ concentrations after 1994 was directly related to the well's distance from recharge site 6 (figs. $11 B$ and $\underline{14 B}$ ), indicating that the increase in $\mathrm{NO}_{3}$ concentrations was related to the artificial-recharge program. In general, the $\mathrm{NO}_{3}$ concentrations in samples from all of these wells, except 36M4, started to decrease after 1998 (fig. 14B). The $\mathrm{NO}_{3}$ concentrations in samples from well 36M5 were fairly constant at $10 \mathrm{mg} / \mathrm{L}$ until mid-1999, then increased slightly to about $15 \mathrm{mg} / \mathrm{L}$ in 2001 (fig. 14B). The delay in the increase in $\mathrm{NO}_{3}$ concentrations in samples from well 36M5 may be explained by the depth and lower permeability of the lower and deep aquifers. The increase in measured $\mathrm{NO}_{3}$ concentrations since 1999 indicate that high- $\mathrm{NO}_{3}$ content water from the upper and middle aquifers may have begun to reach the lower and deep aquifers. 


\section{A West Hydrogeologic Unit}
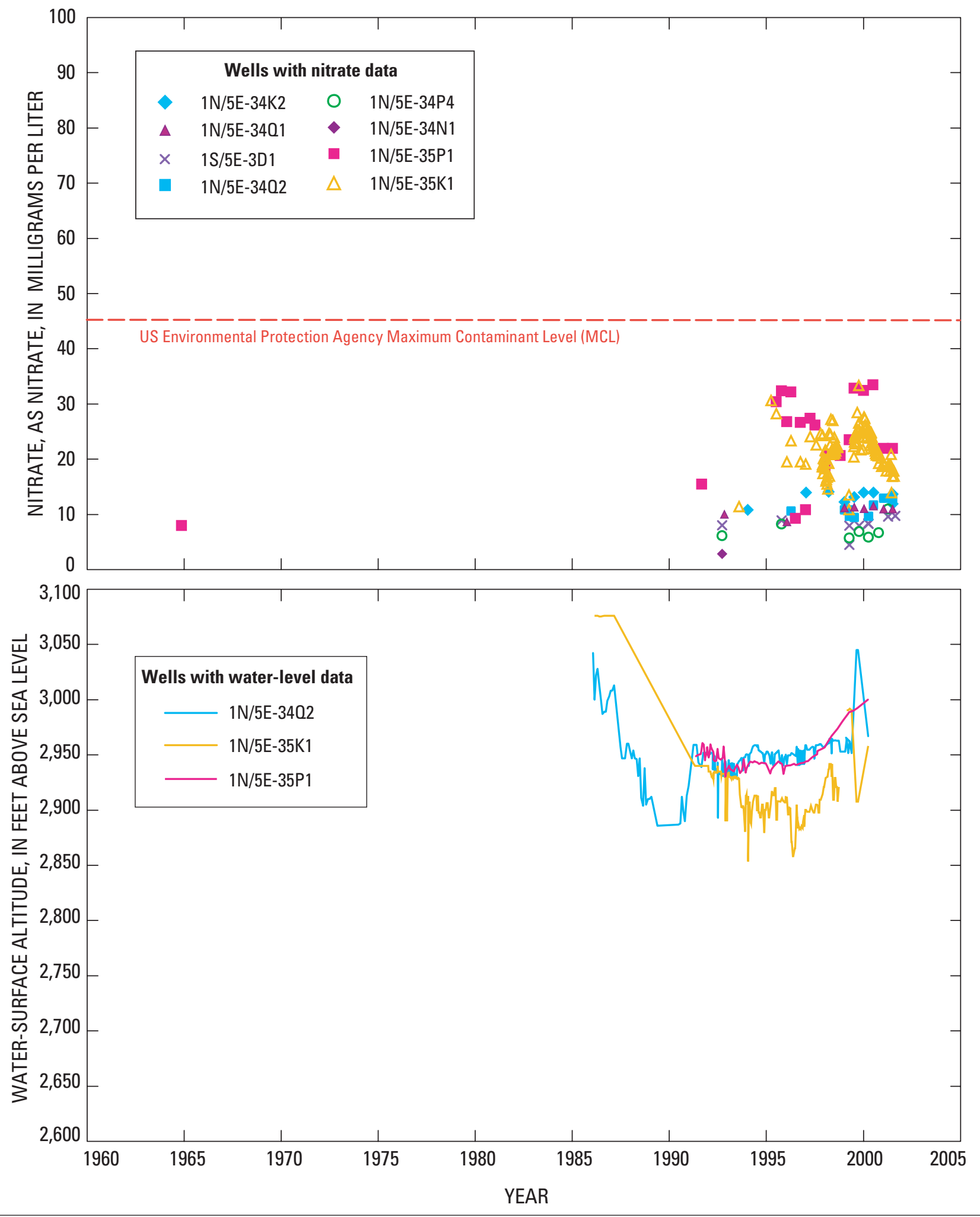

ure 14. Nitrate concentrations in samples from selected Hi-Desert Water District production wells in the $(A)$ west, $(B)$ midwest, $(C)$ mideast, and $(D)$ northeast Irogeologic units, Warren ground-water basin, San Bernardino County, California. 


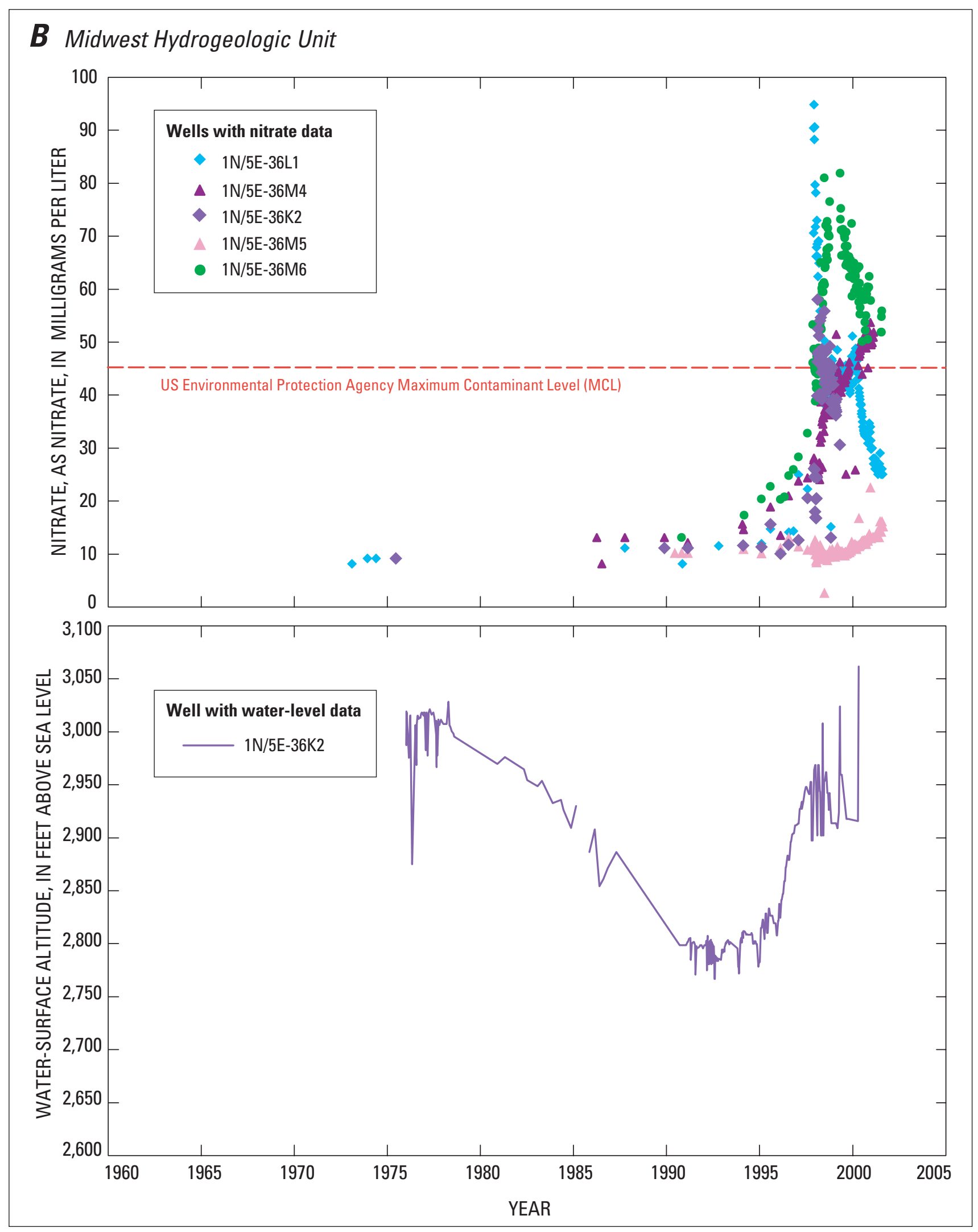

Figure 14.-Continued. 


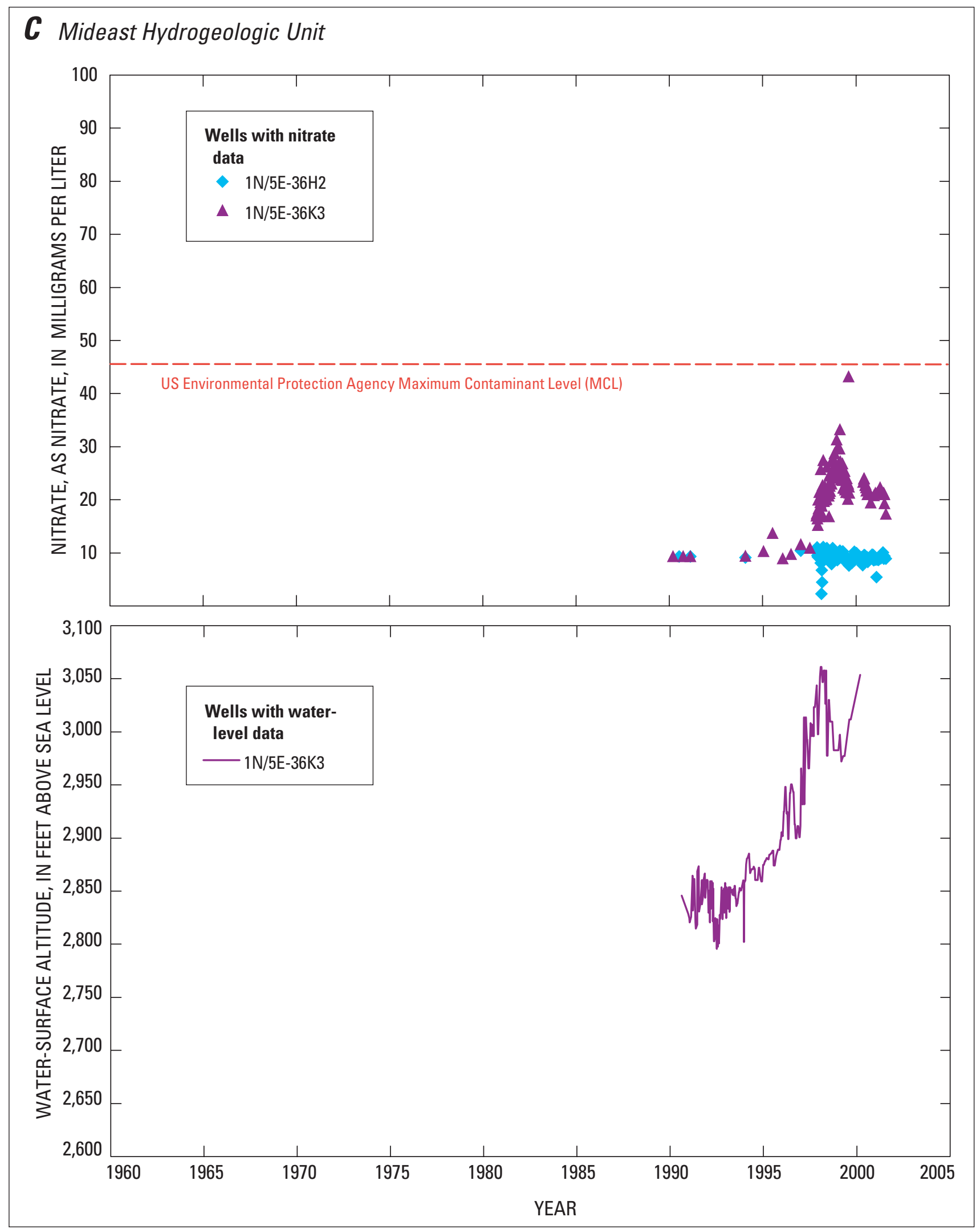

Figure 14.-Continued. 


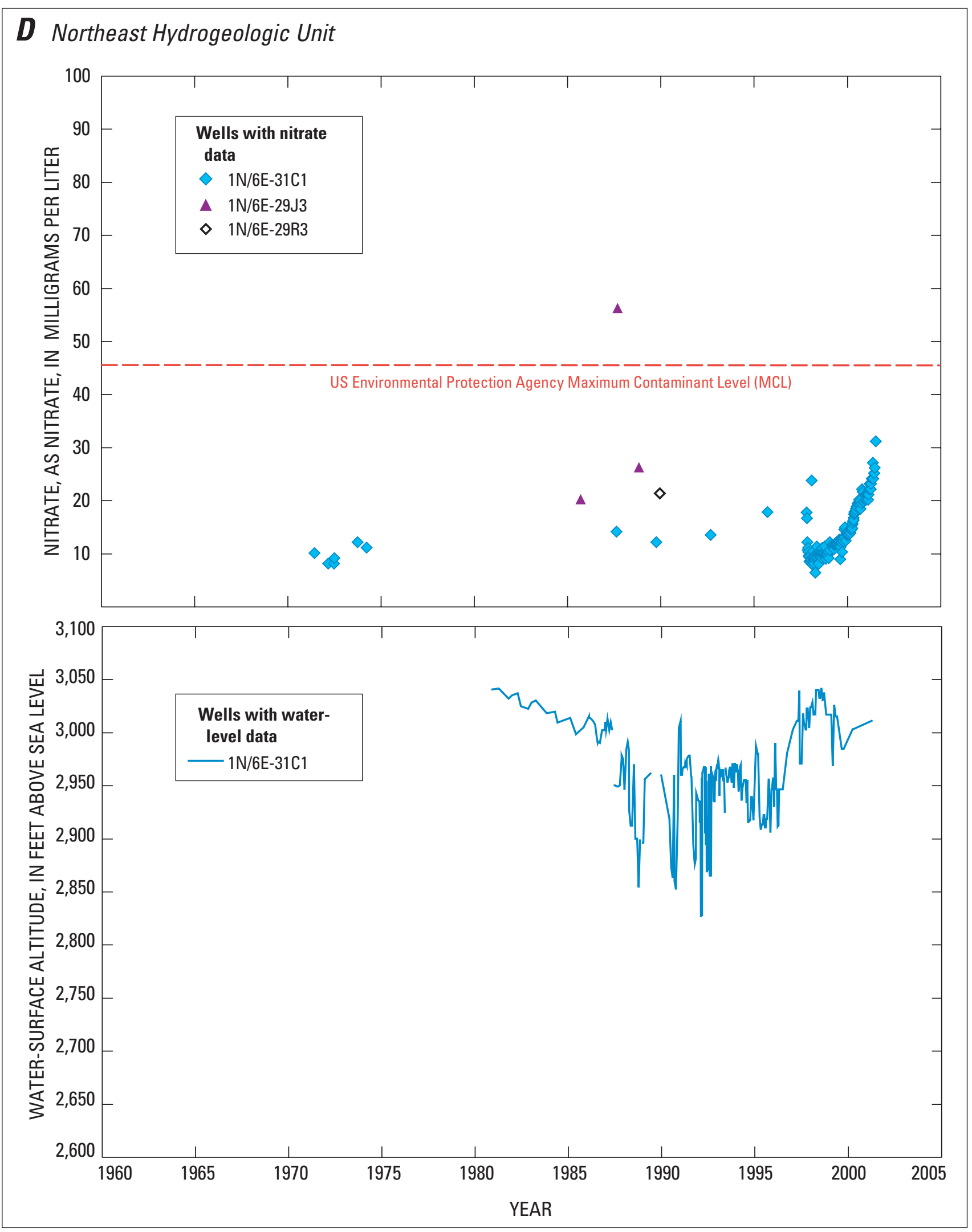

Figure 14.-Continued. 
The $\mathrm{NO}_{3}$ concentrations in samples from well $1 \mathrm{~N} / 5 \mathrm{E}-36 \mathrm{~K} 3$ (14E) in the mideast hydrogeologic unit increased from $10 \mathrm{mg} / \mathrm{L}$ in 1996 to more than $40 \mathrm{mg} / \mathrm{L}$ in 1999 (fig. 14C), approximately coinciding with the $250 \mathrm{ft}$ water-level rise. However, the $\mathrm{NO}_{3}$ concentration in samples from well 1N/5E-36H2 (18E), remained constant at $10 \mathrm{mg} / \mathrm{L}$ although there was a similar $250 \mathrm{ft}$ water-level rise. Well $36 \mathrm{~K} 3$ is perforated in the lower aquifer and well $36 \mathrm{H} 2$ is perforated in the middle and lower aquifers; therefore, one might expect the $\mathrm{NO}_{3}$ concentrations to be higher in well $36 \mathrm{H} 2$. A possible explanation for the difference in $\mathrm{NO}_{3}$ concentrations is that between 1995 and 2000, the pumpage in well $36 \mathrm{~K} 3$ was two to three times greater than that for well $36 \mathrm{H} 2$, which may have induced high- $\mathrm{NO}_{3}$ water to migrate to the lower aquifer at well $36 \mathrm{~K} 3$.

The $\mathrm{NO}_{3}$ concentrations in samples from well $1 \mathrm{~N} / 6 \mathrm{E}-31 \mathrm{C} 1$ (5E) in the northeast hydrogeologic unit increased from about $10 \mathrm{mg} / \mathrm{L}$ in 1974 to more than $15 \mathrm{mg} / \mathrm{L}$ in about 1987 and remained relatively constant until 1997 (fig. 14D). In 1998, the measured $\mathrm{NO}_{3}$ concentrations decreased to less than $10 \mathrm{mg} / \mathrm{L}$ in some samples until 1999 and then increased to more than $30 \mathrm{mg} / \mathrm{L}$ in 2001 (fig. 14D). Sparse, available data for well 1N/6E-29J3 (11E) indicate that $\mathrm{NO}_{3}$ concentrations were as high as $56 \mathrm{mg} / \mathrm{L}$ in 1987. The timing of the high- $\mathrm{NO}_{3}$ concentrations measured in samples from well 29J3 indicated that the high- $\mathrm{NO}_{3}$ concentrations were not related to the artificial recharge program. These high- $\mathrm{NO}_{3}$ concentrations are probably related to septage disposal from nearby areas of residential and commercial land use.

\section{Multiple-Well Monitoring Sites}

$\mathrm{NO}_{3}$ concentrations in samples from wells 1N/5E-36G1-2 [YV1-570 (lower aquifer) and YV1-400 (middle aquifer)] and 1N/5E-36M1 [YV2-570 (lower aquifer)] in the mideast and midwest hydrogeologic units were about $10 \mathrm{mg} / \mathrm{L}$ prior to the start of the artificial recharge program (figs. 15A and $\underline{B}$; table 4). Samples were unavailable from the wells 1N/5E-36G3-4 [YV1-305 and YV1-230 (both upper aquifer)] and 1N/5E-36M2-3 [YV2-390 (middle aquifer) and YV2-300 (upper aquifer)] because these wells were perforated above the water table when installed in 1993. $\mathrm{NO}_{3}$ concentrations in samples from most of the monitoring wells at sites 1N/5E-36G1-4 (YV1) in the mideast hydrogeologic unit and 1N/5E36M1-3 (YV2) in the midwest hydrogeologic unit increased after the start of the artificial-recharge program in 1995 (figs. 15A and $\underline{B}$ ). The maximum $\mathrm{NO}_{3}$ concentrations in samples collected from wells 36G1-4 exceeded $130 \mathrm{mg} / \mathrm{L}$ in wells perforated in the upper and middle aquifers [36G2 (YV1-400), 36G3 (YV1305), and 36G4 (YV1-230)] and were about $10 \mathrm{mg} / \mathrm{L}$ in samples collected from the well perforated in the lower aquifer [36G1 (YV1-570)]. The maximum $\mathrm{NO}_{3}$ concentrations in samples collected from wells 36M1-3 (YV2) did not exceed $40 \mathrm{mg} / \mathrm{L}$ in the wells perforated in the upper and middle aquifers [36M2 (YV2-390) and 36M3 (YV2-300)] and were about $80 \mathrm{mg} / \mathrm{L}$ in samples collected from the well perforated in the lower aquifer [36M1 (YV2-570)].

After recharge began and water levels rose, $\mathrm{NO}_{3}$ concentrations in wells 1N/5E-36G2-4 (YV1-400, YV1-305, and YV1-230) increased to about $130 \mathrm{mg} / \mathrm{L}$ in 1997; however, the concentration in well 1N/5E36G1 (YV1-570), the deepest well at this site, did not change (fig. 15A). $\mathrm{NO}_{3}$ concentrations in 36G4 (YV1-230) started to decrease in 1998 and were less than $20 \mathrm{mg} / \mathrm{L}$ in 2001. The $\mathrm{NO}_{3}$ concentrations in 36G3 (YV1-305) decreased to about $90 \mathrm{mg} / \mathrm{L}$ in early 1998 , increased to about $150 \mathrm{mg} / \mathrm{L}$ in early 1999 , and then decreased to less than $40 \mathrm{mg} / \mathrm{L}$ in 2001 . The $\mathrm{NO}_{3}$ concentrations in well 36G2 (YV1-400) decreased to about $80 \mathrm{mg} / \mathrm{L}$ in mid-1998 and remained relatively constant through 2001. A possible explanation for the high- $\mathrm{NO}_{3}$ concentrations measured at $\mathrm{YV} 1$ may be the leaching of natural-soil $\mathrm{NO}_{3}$ by recharge water or entrainment of septage from septic tanks in nearby housing areas (fig. 2). The decrease in $\mathrm{NO}_{3}$ concentrations was probably the result of dilution by imported water. Recall that $\mathrm{NO}_{3}$ concentrations in samples from well 1N/5E-36G1 (YV1-570) did not change, indicating that there was probably little mixing of water between the upper/middle aquifers and the lower aquifer at recharge site 7 . 


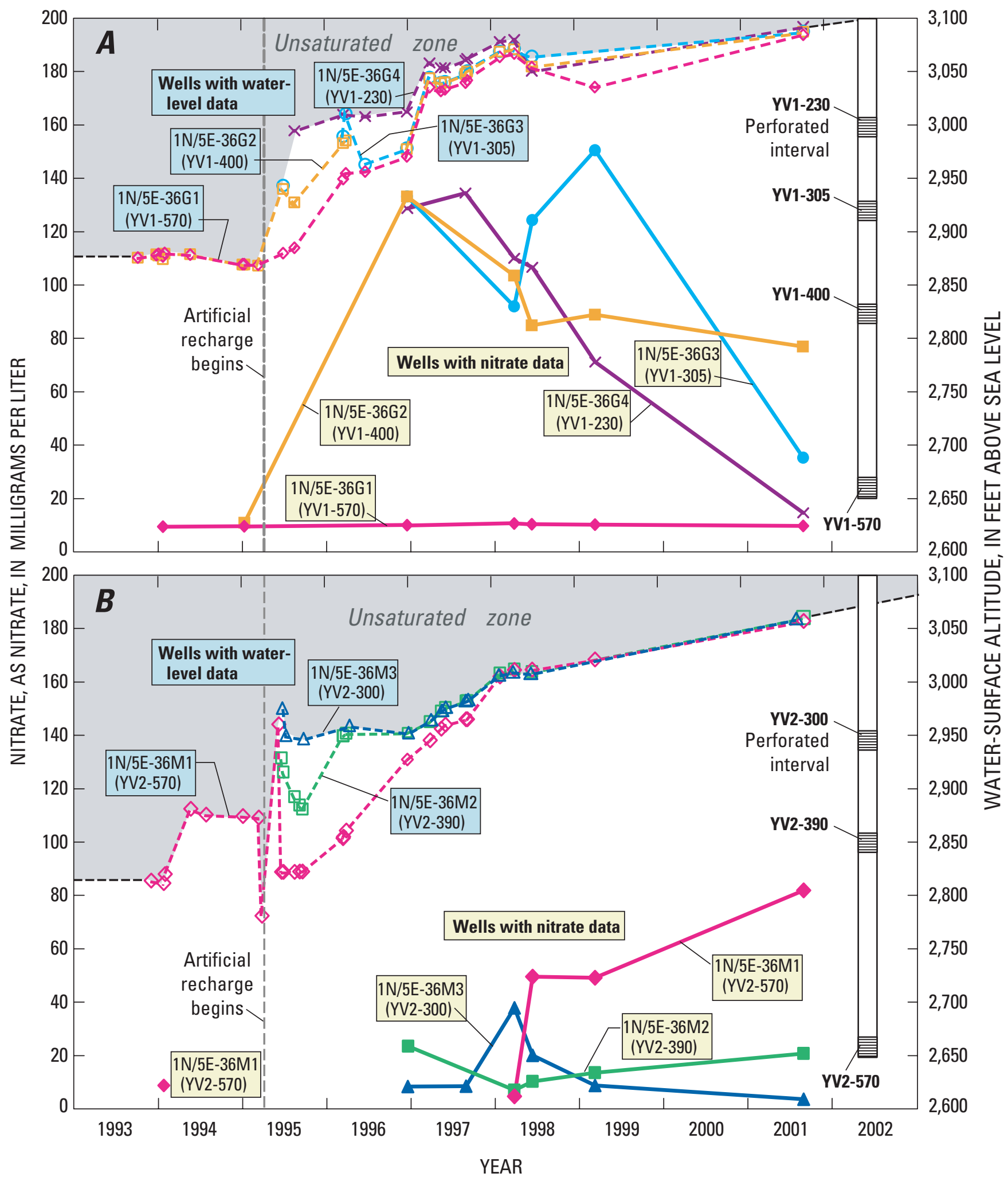

Figure 15. Changes in water-surface altitude and nitrate concentrations in (A) 1N/5E-36G1-4 (YV1) and (B) 1N/5E-36M1-3 (YV2), Warren ground-water basin, San Bernardino County, California. 
$\mathrm{NO}_{3}$ concentrations in well $1 \mathrm{~N} / 5 \mathrm{E}-36 \mathrm{M} 3$

(YV2-300) increased to about $40 \mathrm{mg} / \mathrm{L}$ in early 1998 and decreased to less than $4 \mathrm{mg} / \mathrm{L}$ in 2001 (fig. 15B). $\mathrm{NO}_{3}$ concentrations in well 1N/5E-36M2 (YV2-390) initially increased to $24 \mathrm{mg} / \mathrm{L}$ in 1996 , decreased to less than $10 \mathrm{mg} / \mathrm{L}$ in early 1998 , and slowly increased to $20 \mathrm{mg} / \mathrm{L}$ in 2001 . In contrast, $\mathrm{NO}_{3}$ concentrations in the deep well at this site, 1N/5E-36M1 (YV2-570), increased from less than $10 \mathrm{mg} / \mathrm{L}$ in early 1998 to about $50 \mathrm{mg} / \mathrm{L}$ in mid-1998 and continued to increase to more than $80 \mathrm{mg} / \mathrm{L}$ in $2001 . \mathrm{NO}_{3}$ concentrations in the shallow wells $1 \mathrm{~N} / 5 \mathrm{E}-36 \mathrm{M} 2-3$ were significantly lower than the shallow wells 1N/5E-36G2-4; this may be explained by differences in natural soil $\mathrm{NO}_{3}$ or the proximity of housing areas (and therefore septic tanks) to the sites. That is, the soil beneath well site 1N/5E-36G1-4 may have a greater $\mathrm{NO}_{3}$ concentration than site $1 \mathrm{~N} / 5 \mathrm{E}-36 \mathrm{M} 1-3$ or that housing areas were much closer to the $36 \mathrm{G}$ wells than to $36 \mathrm{M}$ wells increasing the potential for $\mathrm{NO}_{3}$ entrainment (figs. 1 and 2). The presence of high- $\mathrm{NO}_{3}$ concentrations sampled from the deepest well indicates that the downward transport of $\mathrm{NO}_{3}$ by the imported water could not have been the primary transport mechanism of $\mathrm{NO}_{3}$ to ground water at 1N/5E-36M1 (YV2-570). The high $\mathrm{NO}_{3}$ concentrations in well $36 \mathrm{M} 1$ may be the result of horizontal migration of septage from housing areas to the north of site 6 (figs. 1 and 2 ); however, there are no wells in this area to verify this explanation.

\section{Nitrate-to-Chloride Ratios}

The nitrate-to-chloride ratio in ground water can be used as a source indicator because different sources of nitrate and chloride in the Warren ground-water basin have different ratios. Native ground-water ratios ranged from 0.5 to about 1.5 , imported water ratios ranged from 0.006 to less than 0.1 , and septage had a ratio of 1.9. Nitrate-to-chloride ratios for samples of native ground water, imported water, septage collected in Warren ground-water basin, and selected core samples from Victorville, California, are shown in figure 16. Umari and others (1995) reported nitrate-tochloride ratios of less than 0.52 for caliche layers that have high concentrations of natural-soil $\mathrm{NO}_{3}$ near Victorville (note that core samples with $\mathrm{NO}_{3}$ concentrations greater than $180 \mathrm{mg} / \mathrm{L}$ are not shown in figure 16).

Most of the samples from wells in the west hydrogeologic unit plot near native ground water with the exception of wells 1N/5E-35P1 (3W) and 35K1 (11W) and 1S/5E-4A1 (BSGC17) (fig. 16A). These results indicate that artificial recharge had not reached the west hydrogeologic unit.

Most of the samples from wells in the midwest and mideast hydrogeologic units that showed an increase in the $\mathrm{NO}_{3}$ concentration after the start of the artificial recharge program also showed an increase in the nitrate-to-chloride ratio compared to samples collected before the start of the artificial recharge program (fig. 16B and $\underline{C}$ ). Assuming that the nitrate-tochloride ratio for shallow soils in the Warren groundwater basin is similar to the caliche layers sampled in Victorville, the leaching of natural-soil $\mathrm{NO}_{3}$ cannot explain the increase in $\mathrm{NO}_{3}$ concentration because the nitrate-to-chloride ratio for caliche layers is low. That is, if the $\mathrm{NO}_{3}$ source was the caliche layers, then the high- $\mathrm{NO}_{3}$ samples would have shown a decrease in the nitrate-to-chloride ratios. Therefore, the nitrate-tochloride ratios indicate that septage was probably the source of the measured increase in $\mathrm{NO}_{3}$ concentrations in the midwest and mideast hydrogeologic units. 


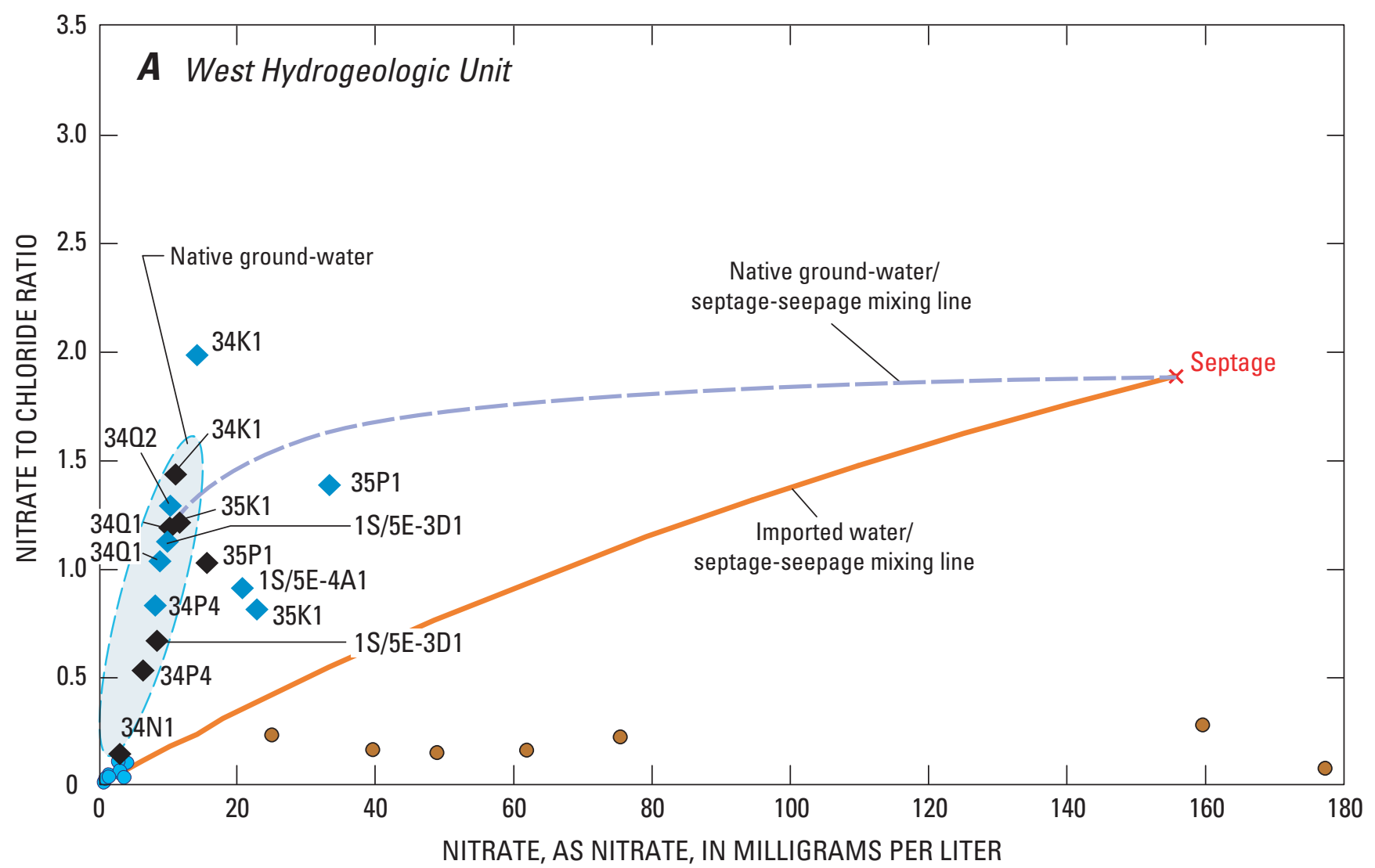

EXPLANATION

(All wells in section 1N/5E unless otherwise noted)

34P4

Well and designation-Sampled before February 1995 recharge

$35 \mathrm{~K} 1$

February 1995 recharge

Well and designation-Sampled after
February 1995 recharge

\section{- Imported water \\ - Core samples- \\ Victorville, California}

Figure 16. Relation between nitrate-to-chloride ratio and nitrate in ground-water samples from wells in the $(A)$ west, $(B)$ midwest, $(C)$ mideast, and $(D)$ northeast and east hydrogeologic units, Warren ground-water basin, San Bernardino County, California. 


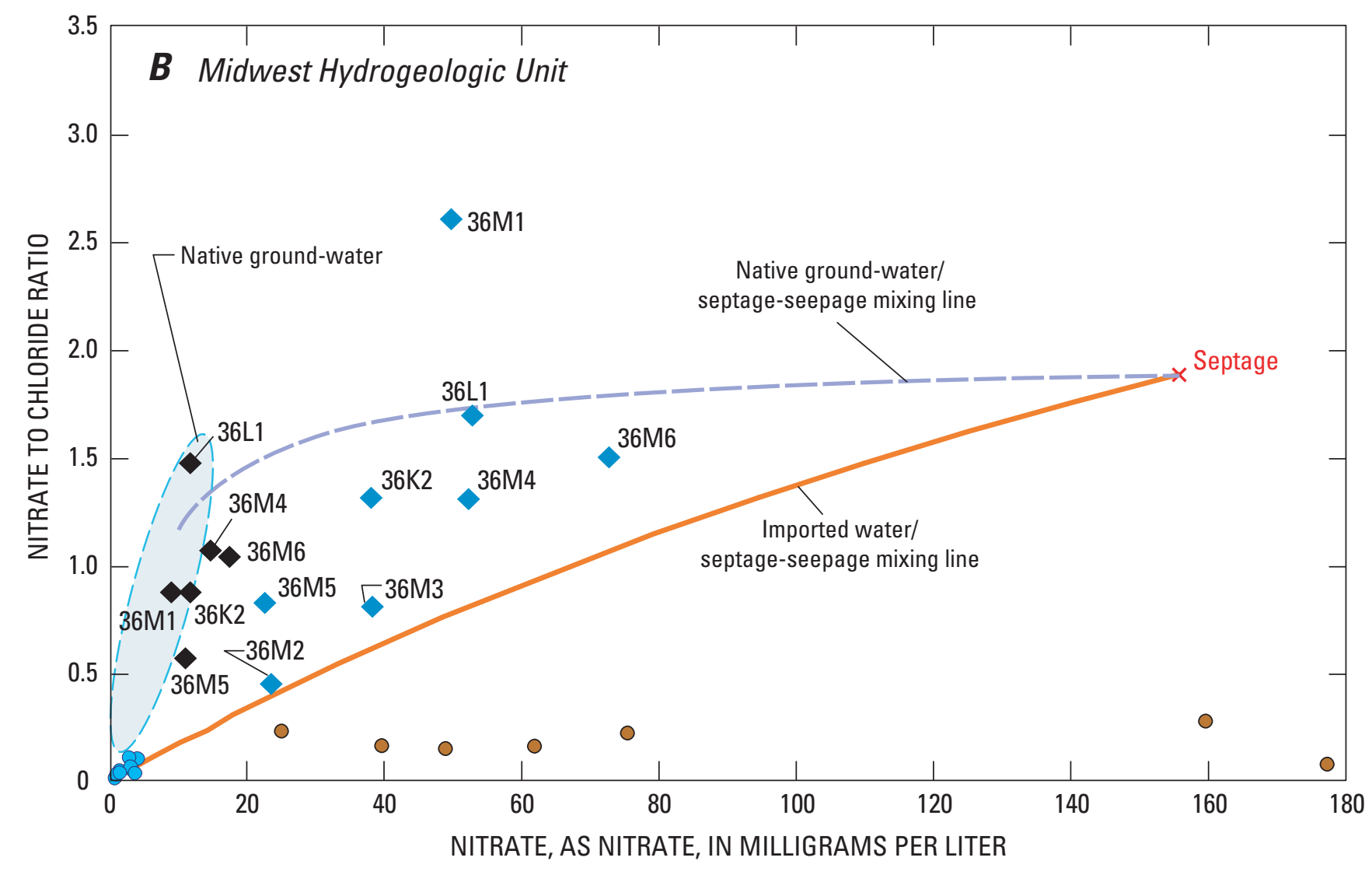

\title{
EXPLANATION
}

(All wells in section $1 \mathrm{~N} / 5 \mathrm{E}$ )

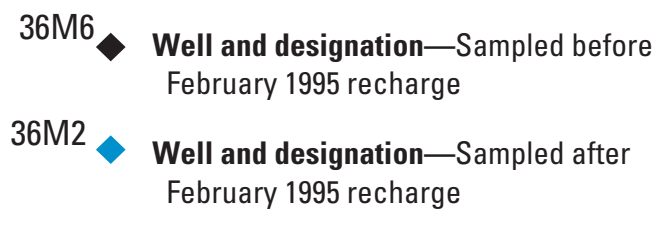

\author{
- Imported water \\ - Core samples- \\ Victorville, California
}

Figure 16. - Continued. 


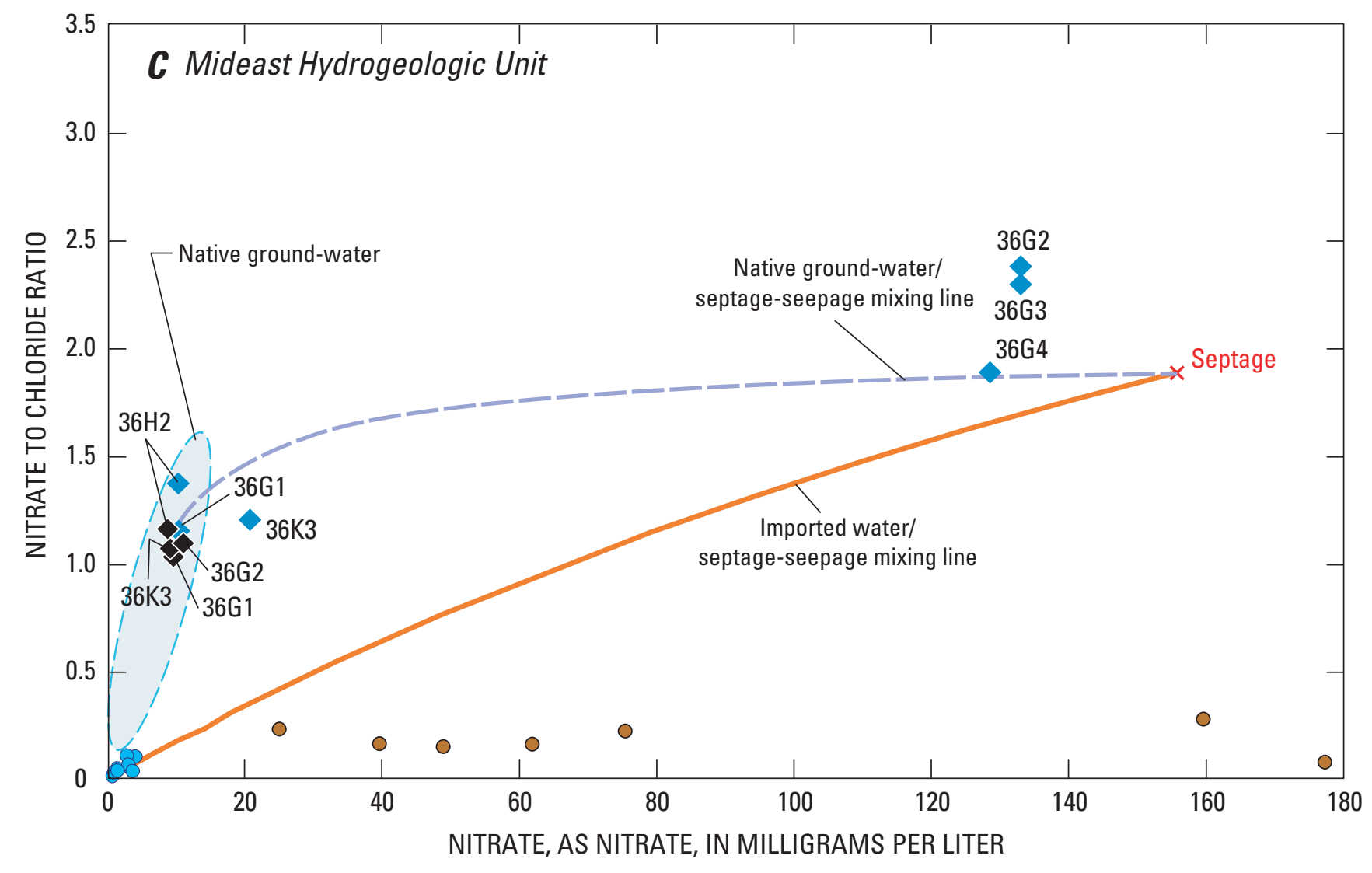

\section{EXPLANATION}

(All wells in section $1 \mathrm{~N} / 5 \mathrm{E}$ )
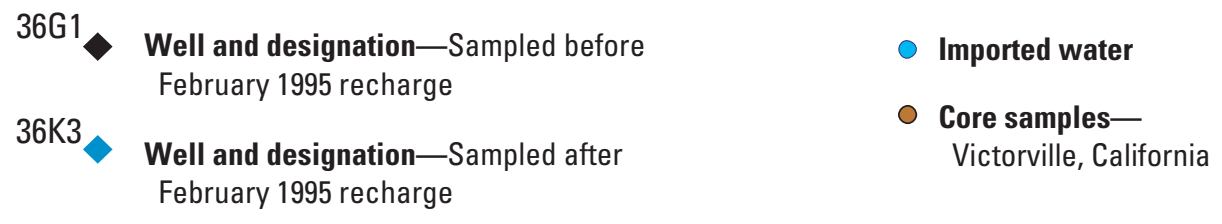

Figure 16. - Continued. 


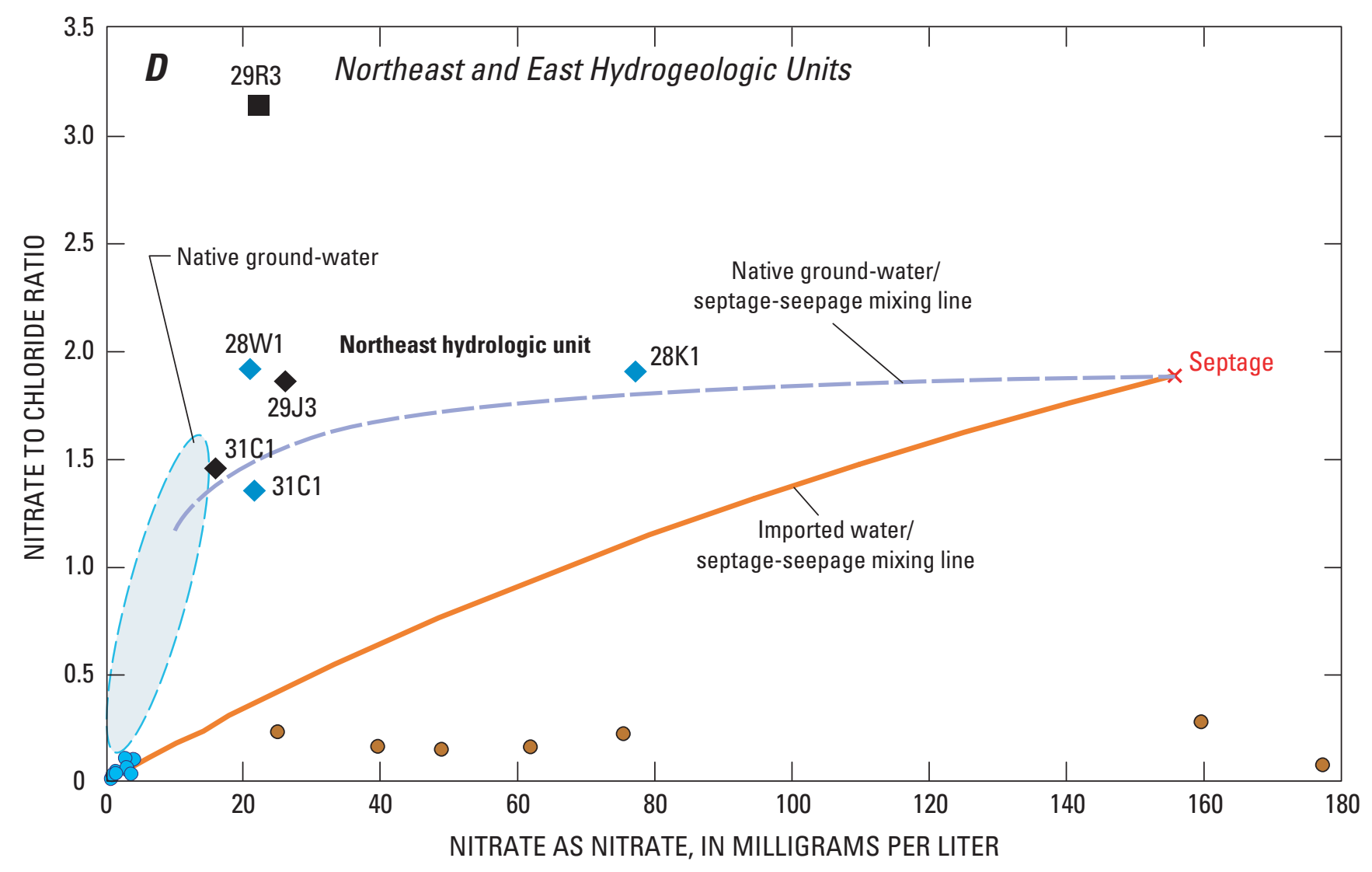

\section{EXPLANATION}

(All wells in section $1 \mathrm{~N} / 6 \mathrm{E}$ )

Northeast hydrogeologic unit

- Well and designation-Sampled before February 1995 recharge

Well and designation-Sampled after February 1995 recharge

\section{East hydrogeologic unit}

Well and designationSampled before February 1995 recharge
- Imported water

- Core samples-

Victorville, California

Figure 16. - Continued. 
As shown in figures $16 B$ and $\underline{C}$, many of the high- $\mathrm{NO}_{3}$ samples collected from wells in the midwest and mideast hydrogeologic units lie below the mixing line of native ground water and septage, suggesting that the samples were affected by mixing with another source of water that had a low nitrate-to-chloride ratio; that is, imported water or water from the caliche layers. However as stated in the "General Chemical

Characteristics" section, samples that had the highest recorded $\mathrm{NO}_{3}$ concentrations from the midwest and mideast hydrogeologic units had similar chemical characteristics to imported water, indicating that mixing between native ground water and imported water had occurred. These results indicate a three-part mixture of native ground water, imported water, and septage. A possible explanation is that as the imported water migrated away from recharge sites 6 and 7, the water entrained septage in the unsaturated zone. Recall that the production wells are perforated over long intervals; therefore, the mixture of imported water and septage could be mixed with native ground water in the wellbore resulting in the three-part mixture in the samples.

Most of the samples from wells in the northeast and east hydrogeologic units plot near the mixing line of native ground water and septage (fig. 16D). These results indicate that the source of $\mathrm{NO}_{3}$ to these wells was probably the downward migration of septage with little or no mixing with artificially recharged imported water. This interpretation is supported by the observations of no water-level rises in response to artificial recharge (figs. $9 C$ and $\underline{D}$ ).

\section{Stable Isotopes of Oxygen and Hydrogen}

The naturally-occurring stable isotopes of oxygen and hydrogen, oxygen-18 and deuterium, have been used to determine the source of ground water in other parts of the Mojave Desert (Izbicki and others, 1995). Water samples were collected from the multiple-well monitoring sites, 22 existing wells, one septic tank, and one sample of imported water. The samples were analyzed for delta oxygen-18 $\left(\delta^{18} \mathrm{O}\right)$ and delta deuterium $(\delta \mathrm{D})$. The results of these isotopic analyses are presented in table 5 .

\section{Background Information}

The ratios of isotopes of oxygen [oxygen-18 $\left({ }^{18} \mathrm{O}\right)$ :oxygen-16 $\left({ }^{16} \mathrm{O}\right)$ ] and hydrogen [deuterium, D $\left({ }^{2} \mathrm{H}\right)$ :hydrogen $\left.\left({ }^{1} \mathrm{H}\right)\right]$ in ground water are indicators of its hydrologic history. The isotopic ratios are expressed in delta notation $(\delta)$ as per mil (parts per thousand) differences relative to the standard known as Vienna Standard Mean Ocean Water (VSMOW) (Gonfiantini, 1978). Higher (less negative) values of $\delta{ }^{18} \mathrm{O}$ and $\delta \mathrm{D}$ represent enrichment in the heavier isotopes of oxygen (oxygen-18) and hydrogen (deuterium), respectively; and lower (more negative) $\delta$ values represent enrichment in the lighter isotope (depletion in the heavier isotope). Craig (1961) found that a linear relation existed between $\delta{ }^{18} \mathrm{O}$ and $\delta \mathrm{D}$ in meteoric waters throughout the world. This relation is referred to as the meteoric water line.

The $\delta{ }^{18} \mathrm{O}$ and $\delta \mathrm{D}$ composition of ground water relative to the meteoric water line and relative to the isotopic composition of water from other sources can be an indicator of the source of ground-water recharge. The isotopic composition of ocean water undergoes fractionation during the transfer from the ocean surface to the vapor phase. Further fractionation occurs as water vapor condenses (for example, as precipitation) from the atmosphere, leaving the remaining water vapor relatively depleted in the heavier isotopes. Latitude, air temperature, and altitude also affect the fractionation of water vapor. The net result is that precipitation from a given storm becomes isotopically lighter as the storm moves inland, and precipitation that forms at lower temperatures is isotopically lighter than precipitation that forms at higher temperatures (Fournier and Thompson, 1980).

When water is evaporated during precipitation or after the precipitation has reached the ground, the lighter isotopes of oxygen and hydrogen are preferentially partitioned into the vapor phase, causing the remaining water to be isotopically heavier than the original precipitation. Isotopic composition does not change further at the low temperatures of most groundwater systems after the recharge water has migrated below the depth at which evaporation occurs. Therefore, any subsequent changes in the isotopic composition of ground water along a flow line generally reflect only the mixing within the aquifer system or concentration by evaporation in a discharge area. 
Table 5. Analyses of stable-isotopes of deuterium and oxygen, tritium, and carbon-14 analyses from selected wells in the Warren ground-water basin, California

[All data collected by U.S. Geological Survey (USGS); number below the compound is the data parameter code, a 5-digit number used in the USGS computerized data system, National Water Information System (NWIS), to uniquely identify a specific constituent or property; <, less than; pCi/L, picocuries per liter; per mil, parts per thousand; - , no data]

\begin{tabular}{|c|c|c|c|c|c|c|}
\hline State well No. & $\begin{array}{l}\text { Local } \\
\text { name }\end{array}$ & Date & $\begin{array}{c}\text { Deuterium } \\
(\delta D) \\
\text { per mil } \\
(82082)\end{array}$ & $\begin{array}{c}\text { Oxygen-18 } \\
\left(\delta^{18} 0\right) \\
\text { per mil } \\
(82085)\end{array}$ & $\begin{array}{c}\text { Tritium, } \\
\text { pCi/L } \\
(07000)\end{array}$ & $\begin{array}{c}\text { Carbon-14, } \\
\text { percent modern } \\
\text { carbon } \\
(49933)\end{array}$ \\
\hline 1N/5E-34K2 & $2 \mathrm{~W}$ & $03 / 25 / 98$ & -72.2 & -10.41 & - & - \\
\hline $1 \mathrm{~N} / 5 \mathrm{E}-34 \mathrm{~K} 2$ & & 07/10/01 & -71.2 & -10.42 & - & - \\
\hline $1 \mathrm{~N} / 5 \mathrm{E}-34 \mathrm{P} 4$ & $10 \mathrm{~W}$ & 06/18/96 & -79.7 & -11.20 & 3.1 & 67.4 \\
\hline 1N/5E-34Q2 & $9 \mathrm{~W}$ & 08/07/96 & -75.7 & -10.81 & 8.2 & 84.4 \\
\hline 1N/5E-34Q2 & & 08/27/01 & -76.8 & -10.99 & - & - \\
\hline $1 \mathrm{~N} / 5 \mathrm{E}-35 \mathrm{~K} 1$ & $11 \mathrm{~W}$ & $03 / 24 / 98$ & -75.3 & -10.45 & - & - \\
\hline $1 \mathrm{~N} / 5 \mathrm{E}-35 \mathrm{P} 1$ & $3 \mathrm{~W}$ & $06 / 18 / 96$ & -77.1 & -11.23 & 4.0 & - \\
\hline 1N/5E-35P1 & & $03 / 25 / 98$ & -78.2 & -11.07 & - & - \\
\hline 1N/5E-36G1 & YV1-570 & 09/09/93 & -78.9 & -11.25 & - & - \\
\hline 1N/5E-36G1 & & $01 / 25 / 94$ & -77.0 & -11.09 & $<.3$ & - \\
\hline 1N/5E-36G1 & & $01 / 12 / 95$ & -77.8 & -11.11 & - & - \\
\hline 1N/5E-36G1 & & $12 / 17 / 96$ & -78.9 & -11.13 & - & 79.5 \\
\hline 1N/5E-36G1 & & $03 / 25 / 98$ & -78.2 & -11.12 & - & - \\
\hline 1N/5E-36G1 & & 06/10/98 & -77.1 & -11.14 & - & - \\
\hline 1N/5E-36G1 & & 03/10/99 & -77.4 & -11.18 & - & - \\
\hline 1N/5E-36G1 & & 08/28/01 & -79.0 & -11.15 & - & - \\
\hline $1 \mathrm{~N} / 5 \mathrm{E}-36 \mathrm{G} 2$ & YV1-400 & 09/09/93 & -74.3 & -10.58 & - & - \\
\hline 1N/5E-36G2 & & $01 / 25 / 94$ & -76.3 & -11.01 & - & - \\
\hline 1N/5E-36G2 & & $01 / 13 / 95$ & -77.3 & -11.10 & - & - \\
\hline 1N/5E-36G2 & & $12 / 17 / 96$ & -75.6 & -10.73 & - & - \\
\hline 1N/5E-36G2 & & $03 / 25 / 98$ & -74.5 & -10.23 & - & - \\
\hline 1N/5E-36G2 & & 06/10/98 & -73.0 & -10.14 & - & - \\
\hline 1N/5E-36G2 & & 03/10/99 & -73.5 & -9.98 & - & - \\
\hline 1N/5E-36G2 & & 08/27/01 & -72.3 & -9.93 & - & - \\
\hline 1N/5E-36G3 & YV1-305 & $12 / 17 / 96$ & -77.6 & -10.71 & - & - \\
\hline 1N/5E-36G3 & & $03 / 25 / 98$ & -74.2 & -10.35 & - & - \\
\hline $1 \mathrm{~N} / 5 \mathrm{E}-36 \mathrm{G} 3$ & & $06 / 12 / 98$ & -75.2 & -10.29 & - & - \\
\hline 1N/5E-36G3 & & 03/10/99 & -74.6 & -10.43 & - & - \\
\hline $1 \mathrm{~N} / 5 \mathrm{E}-36 \mathrm{G} 3$ & & 08/28/01 & -72.0 & -9.60 & - & - \\
\hline 1N/5E-36G4 & YV1-230 & $06 / 18 / 96$ & -75.8 & -10.75 & - & - \\
\hline 1N/5E-36G4 & & $12 / 18 / 96$ & -74.9 & -10.62 & - & - \\
\hline 1N/5E-36G4 & & $08 / 26 / 97$ & -75.6 & -10.19 & - & - \\
\hline 1N/5E-36G4 & & $03 / 25 / 98$ & -73.6 & -10.16 & - & - \\
\hline 1N/5E-36G4 & & $06 / 12 / 98$ & -72.7 & -9.79 & - & - \\
\hline 1N/5E-36G4 & & $03 / 11 / 99$ & -72.7 & -9.84 & - & - \\
\hline 1N/5E-36G4 & & 08/28/01 & -71.5 & -9.52 & - & - \\
\hline $1 \mathrm{~N} / 5 \mathrm{E}-36 \mathrm{H} 2$ & $18 \mathrm{E}$ & $03 / 25 / 98$ & -77.6 & -11.05 & - & - \\
\hline $1 \mathrm{~N} / 5 \mathrm{E}-36 \mathrm{~K} 2$ & $9 \mathrm{E}$ & $12 / 03 / 92$ & -77.7 & -11.02 & - & - \\
\hline $1 \mathrm{~N} / 5 \mathrm{E}-36 \mathrm{~K} 2$ & & $01 / 25 / 94$ & -78.8 & -11.08 & - & - \\
\hline $1 \mathrm{~N} / 5 \mathrm{E}-36 \mathrm{~K} 2$ & & $03 / 24 / 98$ & -78.1 & -10.98 & - & - \\
\hline $1 \mathrm{~N} / 5 \mathrm{E}-36 \mathrm{~K} 3$ & $14 \mathrm{E}$ & $01 / 25 / 94$ & -78.1 & -11.15 & - & - \\
\hline
\end{tabular}


Table 5. Analyses of stable-isotopes of deuterium and oxygen, tritium, and carbon-14 analyses from selected wells in the Warren ground-water basin, California-Continued

\begin{tabular}{|c|c|c|c|c|c|c|}
\hline State well No. & $\begin{array}{l}\text { Local } \\
\text { name }\end{array}$ & Date & $\begin{array}{c}\text { Deuterium } \\
(\delta D) \\
\text { per mil } \\
(\mathbf{8 2 0 8 2})\end{array}$ & $\begin{array}{c}\text { Oxygen-18 } \\
\left(\delta^{18} 0\right) \\
\text { per mil } \\
(82085)\end{array}$ & $\begin{array}{c}\text { Tritium, } \\
\text { pCi/L } \\
(07000)\end{array}$ & $\begin{array}{c}\text { Carbon-14, } \\
\text { percent modern } \\
\text { carbon } \\
(49933)\end{array}$ \\
\hline 1N/5E-36K3 & & $03 / 24 / 98$ & -79.0 & -11.14 & - & - \\
\hline $1 \mathrm{~N} / 5 \mathrm{E}-36 \mathrm{~K} 3$ & & 07/11/01 & -74.3 & -10.25 & - & - \\
\hline 1N/5E-36L1 & $7 \mathrm{E}$ & $03 / 24 / 98$ & -74.1 & -10.49 & - & - \\
\hline 1N/5E-36L1 & & 07/10/01 & -75.0 & -10.40 & - & - \\
\hline 1N/5E-36M1 & YV2-570 & $01 / 25 / 94$ & -77.8 & -11.08 & $<0.3$ & - \\
\hline $1 \mathrm{~N} / 5 \mathrm{E}-36 \mathrm{M} 1$ & & $12 / 18 / 96$ & -77.2 & -11.07 & - & 69.3 \\
\hline 1N/5E-36M1 & & $03 / 24 / 98$ & -77.9 & -10.90 & - & - \\
\hline 1N/5E-36M1 & & $06 / 12 / 98$ & -77.8 & -11.00 & - & - \\
\hline 1N/5E-36M1 & & 03/09/99 & -78.7 & -11.02 & - & - \\
\hline 1N/5E-36M1 & & 08/29/01 & -78.3 & -10.85 & - & - \\
\hline $1 \mathrm{~N} / 5 \mathrm{E}-36 \mathrm{M} 2$ & YV2-390 & $12 / 19 / 96$ & -70.4 & -9.44 & - & - \\
\hline $1 \mathrm{~N} / 5 \mathrm{E}-36 \mathrm{M} 2$ & & $03 / 24 / 98$ & -69.6 & -9.07 & - & - \\
\hline $1 \mathrm{~N} / 5 \mathrm{E}-36 \mathrm{M} 2$ & & 06/11/98 & -69.3 & -9.11 & - & - \\
\hline $1 \mathrm{~N} / 5 \mathrm{E}-36 \mathrm{M} 2$ & & 03/09/99 & -69.9 & -9.19 & - & - \\
\hline $1 \mathrm{~N} / 5 \mathrm{E}-36 \mathrm{M} 2$ & & 08/29/01 & -70.0 & -9.47 & - & - \\
\hline $1 \mathrm{~N} / 5 \mathrm{E}-36 \mathrm{M} 3$ & YV2-300 & $12 / 17 / 96$ & -69.2 & -9.19 & - & - \\
\hline $1 \mathrm{~N} / 5 \mathrm{E}-36 \mathrm{M} 3$ & & 08/27/97 & -71.1 & -9.36 & - & - \\
\hline $1 \mathrm{~N} / 5 \mathrm{E}-36 \mathrm{M} 3$ & & $03 / 24 / 98$ & -68.9 & -9.22 & - & - \\
\hline $1 \mathrm{~N} / 5 \mathrm{E}-36 \mathrm{M} 3$ & & 06/11/98 & -70.3 & -9.36 & - & - \\
\hline $1 \mathrm{~N} / 5 \mathrm{E}-36 \mathrm{M} 3$ & & 03/10/99 & -75.3 & -9.99 & - & - \\
\hline $1 \mathrm{~N} / 5 \mathrm{E}-36 \mathrm{M} 3$ & & 08/29/01 & -74.3 & -9.55 & - & - \\
\hline $1 \mathrm{~N} / 5 \mathrm{E}-36 \mathrm{M} 4$ & $12 \mathrm{E}$ & $03 / 24 / 98$ & -76.5 & -10.63 & - & - \\
\hline $1 \mathrm{~N} / 5 \mathrm{E}-36 \mathrm{M} 4$ & & $04 / 05 / 00$ & -74.1 & -10.57 & - & - \\
\hline 1N/5E-36M5 & $16 \mathrm{E}$ & $03 / 24 / 98$ & -77.5 & -10.95 & - & - \\
\hline 1N/5E-36M6 & $17 \mathrm{E}$ & $03 / 24 / 98$ & -75.6 & -10.85 & - & - \\
\hline 1N/5E-36M6 & & 05/07/98 & -76.3 & -10.88 & - & - \\
\hline 1N/5E-36M6 & & 07/10/01 & -74.3 & -10.38 & - & - \\
\hline 1N/6E-28K1 & & 07/19/99 & -77.7 & -10.81 & - & - \\
\hline 1N/6E-28K1 & & 08/31/99 & -75.9 & -10.73 & 2.9 & 71.5 \\
\hline $1 \mathrm{~N} / 6 \mathrm{E}-28 \mathrm{~N} 1$ & & 08/31/99 & -78.2 & -11.17 & $<.3$ & 72.4 \\
\hline 1S/5E-3D1 & $8 \mathrm{~W}$ & $04 / 05 / 00$ & -73.5 & -10.92 & - & - \\
\hline $1 \mathrm{~S} / 5 \mathrm{E}-3 \mathrm{D} 1$ & & $08 / 27 / 01$ & -76.3 & -10.88 & - & - \\
\hline 1S/5E-4A1 & BSGC 17 & 07/11/01 & -78.4 & -11.15 & - & - \\
\hline 1S/5E-10D2 & & 08/16/96 & -74.6 & -9.90 & 8.6 & 104.0 \\
\hline RECHARGE POND & & $08 / 27 / 97$ & -68.0 & -8.92 & - & - \\
\hline SEPTIC TANK & & $10 / 08 / 98$ & -75.5 & -10.84 & - & - \\
\hline
\end{tabular}




\section{Results}

The $\delta{ }^{18} \mathrm{O}$ and $\delta \mathrm{D}$ values of waters sampled as part of this study ranged from -8.92 to -11.25 per mil, and -68.0 to -79.7 per mil, respectively (table 5). For the purposes of this discussion, native ground water is represented by samples collected before February 1995 or by samples with $\mathrm{NO}_{3}$ concentrations of about 10 $\mathrm{mg} / \mathrm{L}$ (see table 4 for $\mathrm{NO}_{3}$ concentrations). Native ground-water is isotopically light and has isotopic compositions ranging from -10.58 to -11.25 per mil $\delta^{18} \mathrm{O}$ and -74.3 to -79.0 per mil $\delta \mathrm{D}$; these values reflect the isotopic composition of local precipitation and precipitation runoff. Imported water sampled during this study was isotopically heavy and had an isotopic composition of -8.92 per mil $\delta^{18} \mathrm{O}$ and -68.0 per mil $\delta \mathrm{D}$; these values reflect the different source area of this water (northern California precipitation) and the evaporative history of the imported water as it was transported south in canals and stored in reservoirs.

In general, the isotopic data indicate that the ground water is becoming isotopically similar to imported water in the midwest and mideast hydrogeologic units (figs. 17A and $\underline{B}$ ). Specifically, the isotopic data for most of these samples plot along the mixing line between native ground water and imported water (figs. $17 A$ and $\underline{B}$ ).

Figure 18 shows $\mathrm{NO}_{3}$ concentrations and $\delta^{18} \mathrm{O}$ values for the multiple samples collected at monitoring wells 1N/5E-36G1-4 (YV1) and 1N/5E-36M1-3 (YV2) before (pre-1995) and during the artificial recharge program. Prior to 1995, wells 1N/5E-36G3-4 (YV1-305 and YV1-230, respectively) and 1N/5E36M2-3 (YV2-390 and YV2-300, respectively) were perforated in the unsaturated zone and could not be sampled until 1996 after the water table had risen above the perforated intervals of these wells. Samples collected in 1996 from wells 36G2-4 had $\mathrm{NO}_{3}$ concentrations and $\delta{ }^{18} \mathrm{O}$ values similar to those of the septage sample (about $130 \mathrm{mg} / \mathrm{L}$ and about -10.75 per mil, respectively) (fig. 18A). Note that the samples from well $36 \mathrm{G} 2$ followed a mixing line between native ground water and septage from 1995 to 1996. After 1996, samples collected from wells 36G2-4 generally followed a mixing line between septage and imported water. In 2001, the samples collected from wells
36G3-4 (the shallowest monitoring wells) had $\mathrm{NO}_{3}$ concentrations and $\delta^{18} \mathrm{O}$ values approaching those of imported water (fig. 18A). The samples collected from well 1N/5E-36G1 (YV1-570), the deepest well at the site, did not change with time (fig. 18A).

A possible explanation for the initial increase in $\mathrm{NO}_{3}$ concentrations in samples collected from wells 1N/5E-36G2-4 (YV1-400, 305, and 230) could be that the recharged imported water forced the high- $\mathrm{NO}_{3}$ water, present beneath the recharge ponds at site 7 in the unsaturated zone, down to the water table (similar to plug flow). Once the high- $\mathrm{NO}_{3}$ water reached the water table, it mixed with the native ground water and moved away from the site along the hydraulic gradient. Subsequently, the recharged imported water reached the water table and diluted the mixture of high- $\mathrm{NO}_{3}$ water and native ground water, explaining the measured decrease in $\mathrm{NO}_{3}$ concentrations in samples from wells 36G2-4.

Samples collected from wells 1N/5E-36M2-3 (YV2-390 and 300, respectively) after 1996 had significantly lower $\mathrm{NO}_{3}$ concentrations (less than 40 $\mathrm{mg} / \mathrm{L})$ than those from wells $1 \mathrm{~N} / 5 \mathrm{E}-36 \mathrm{G} 2-4$ and $\delta^{18} \mathrm{O}$ values similar to imported water (about -9.0 per mil) (fig. 18B). As stated earlier, a possible explanation for the lower $\mathrm{NO}_{3}$ concentrations in these samples may be that housing areas (and therefore septic tanks) are a greater distance from site 6 than site 7; therefore, the volume of septage in the unsaturated zone beneath site 6 was probably less than beneath site 7 . The samples collected from well 1N/5E-36M1 (YV2-570) showed an increase in $\mathrm{NO}_{3}$ concentrations starting in about June 1998 and peaked in 2001 at about $80 \mathrm{mg} / \mathrm{L}$; there was only a slight increase in $\delta{ }^{18} \mathrm{O}$ values of about 0.85 per mil (fig. 18B $)$. The samples from well 36M1 followed a mixing line between native ground water and septage from 1994 to 2001 (fig. 18B). The high$\mathrm{NO}_{3}$ concentrations in samples from well 36M1 could not be the result of only vertical migration because the measured $\mathrm{NO}_{3}$ concentrations were higher than those from samples from shallower wells. The high- $\mathrm{NO}_{3}$ concentrations in samples from well $36 \mathrm{M} 1$ may be the result of horizontal migration of septage from housing areas north of site 6 (figs. 1 and 2); however, there are no wells in this area to verify this explanation. 


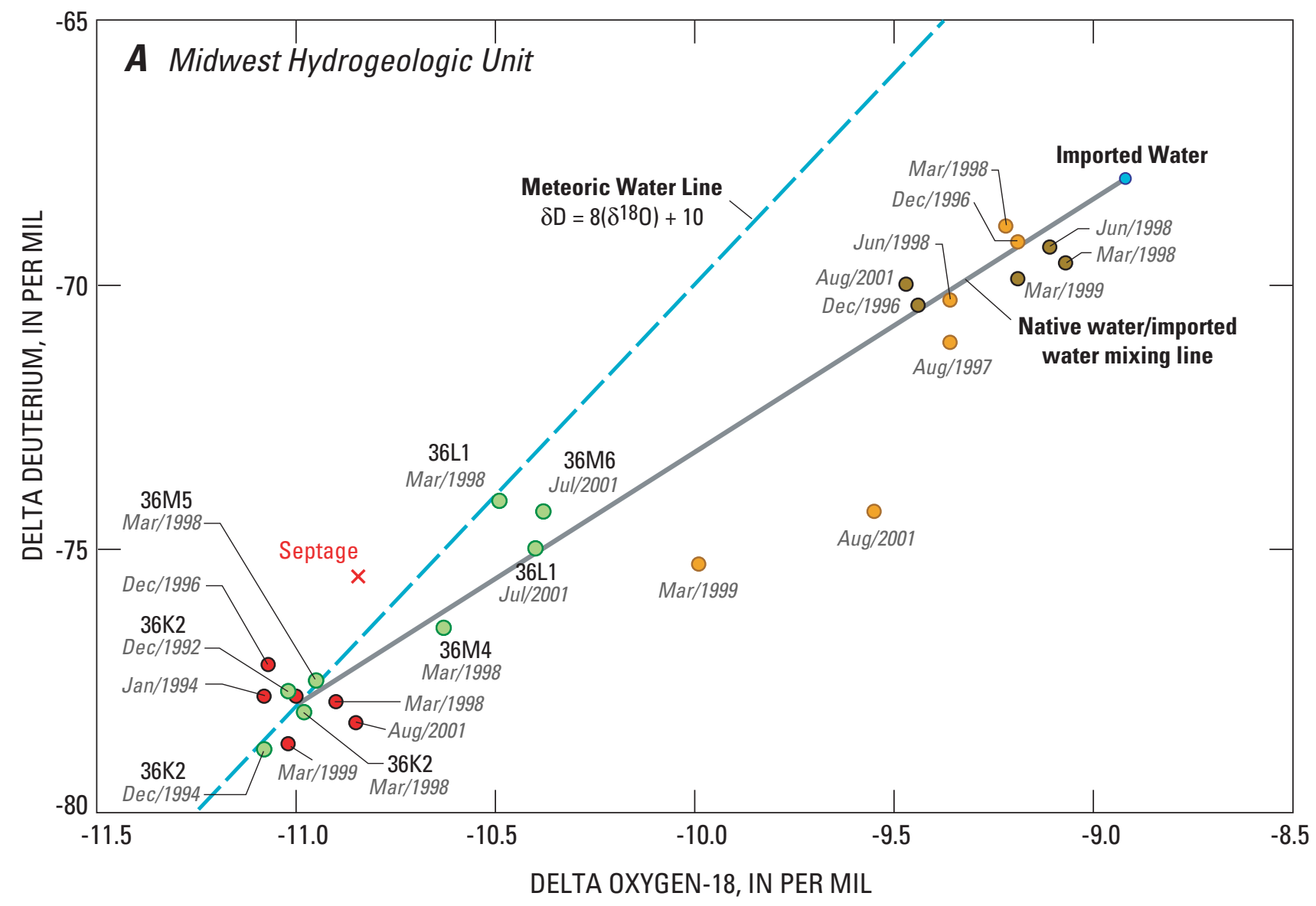

\section{EXPLANATION}

Multiple-well monitoring site and designation(Wells located in $1 \mathrm{~N} / 5 \mathrm{E}$ )

$\begin{array}{ll}\circ & 36 \mathrm{M} 1 \text { (YV2-570) } \\ \circ & 36 \mathrm{M} 2 \text { (YV2-390) } \\ \circ & 36 \mathrm{M} 3 \text { (YV2-300) }\end{array}$

${ }^{36 K 2} \circ$ Other wells and designation

Dec/1996 Number at data points indicates month and year sampled

Figure 17. Stable isotopes from ground-water samples collected from selected wells in the $(A)$ midwest and $(B)$ mideast hydrogeologic units, Warren ground-water basin, San Bernardino County, California. 


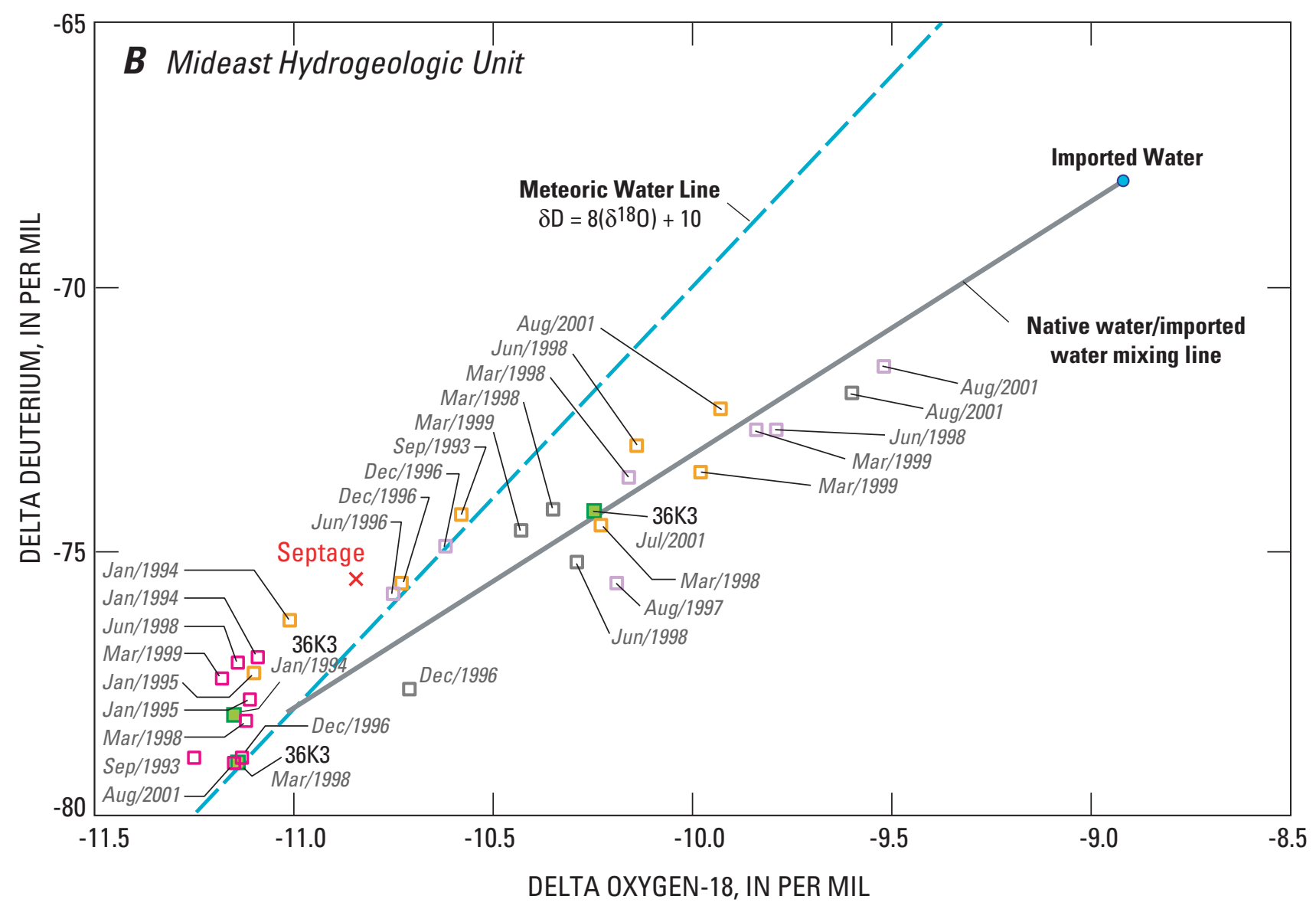

EXPLANATION

Multiple-well monitoring site and designation(Wells located in $1 \mathrm{~N} / 5 \mathrm{E}$ )

$\begin{array}{lcc}\square \text { 36G1 (YV1-570) } & 36 K 3 \square \quad \text { Other wells and designation } \\ \square 36 G 2 \text { (YV1-400) } & \text { Dec/1996 } & \text { Number at data points indicates month } \\ \square 36 G 3(Y V 1-305) & \text { and year sampled } \\ \square 36 G 4 \text { (YV1-230) } & \end{array}$

Figure 17.-Continued. 


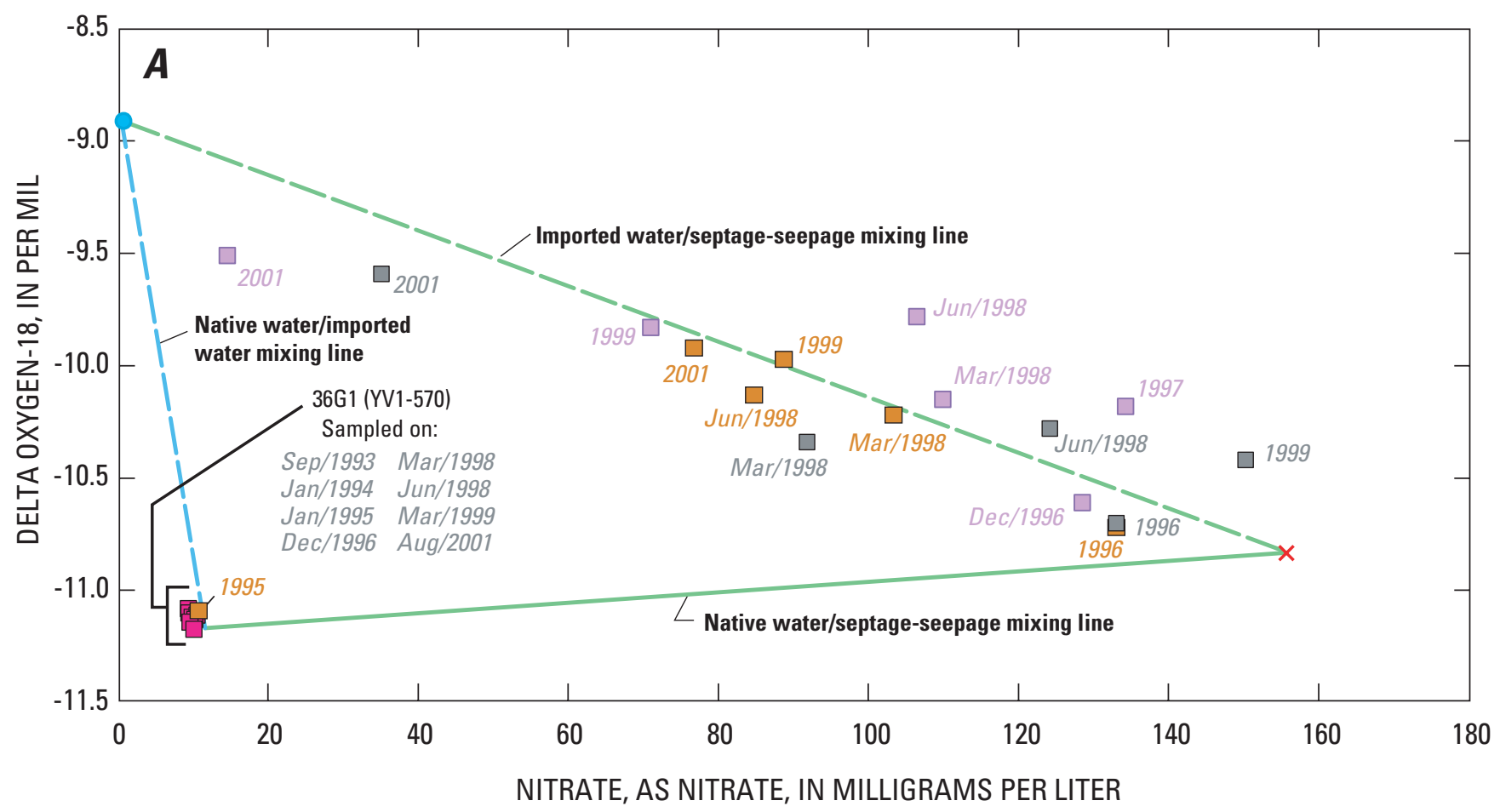

\section{EXPLANATION}

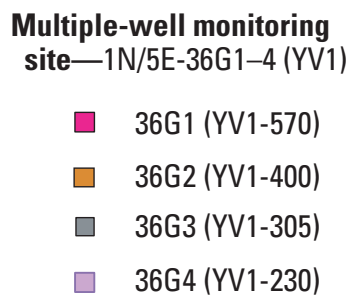

- Imported water

$\times$ Septage

Mar/1998 Number at data points indicates year sampled; month is shown if site was sampled more than once in a year

Figure 18. Relation between delta oxygen-18 and nitrate from ground-water samples from multiple-well monitoring sites: $(A)$ 1N/5E-36G1-4 (YV1) and (B) 1N/5E-36M1-3 (YV2), Warren ground-water basin, San Bernardino County, California. (Number at data points indicates year sampled; month is shown if site was sampled more than once in a year.) 


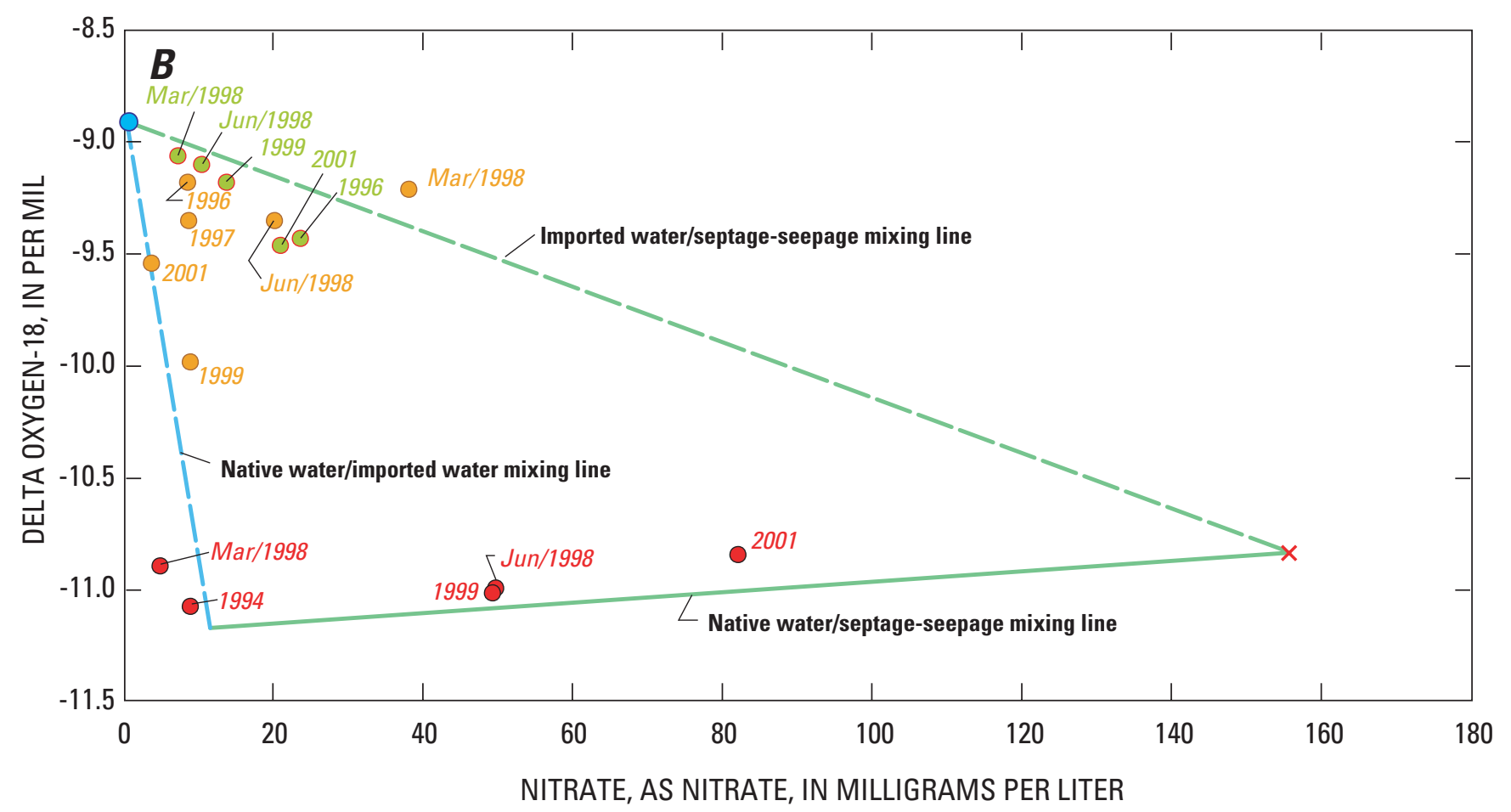

\section{EXPLANATION}

Multiple-well monitoring site-1N/5E-36M1-3 (YV2)

- 36M1 (YV2-570)

- 36M2 (YV2-390)

- 36M3 (YV2-300)
Imported water

$\times$ Septage

Mar/1998 Number at data points indicates year sampled; month is shown if site was sampled more than once in a year

Figure 18--Continued. 
Nitrogen Isotopes

To evaluate the source of $\mathrm{NO}_{3}$ in the Warren ground-water basin, 42 water samples were collected from 20 wells and analyzed for nitrogen isotopes and $\mathrm{NO}_{3}$ concentrations (table 6). These samples were compared with the four soil samples collected and analyzed for total-nitrogen, leachable nitrate, and nitrogen isotopes. Previous studies have used nitrogen isotopes to identify the source of $\mathrm{NO}_{3}$ in ground water (Kreitler, 1975; Gormly and Spalding, 1979; Martin, 1980; Heaton, 1986). Specifically, the ratio of isotopes of nitrogen [nitrogen-15 $\left({ }^{15} N\right)$ :nitrogen-14 $\left({ }^{14} N\right)$ ] has been used to differentiate various sources of $\mathrm{NO}_{3}$.

The isotopic ratio $\left({ }^{15} N:{ }^{14} N\right)$ is expressed in delta notation $(\delta)$ as per mil (parts per thousand) difference relative to atmospheric molecular $\mathrm{N}_{2}$, that is:

$\delta{ }^{15} N=\frac{\left({ }^{15} N /{ }^{14} N_{\text {sample }}-{ }^{15} N /{ }^{14} N_{\text {standard }}\right)-1,000}{{ }^{15} N /{ }^{14} N_{\text {standard }}}(1)$

Higher $\delta{ }^{15} N$ values represent enrichment in the heavier isotope of nitrogen $\left({ }^{15} N\right)$ and lower values represent enrichment in the lighter isotope of nitrogen $\left({ }^{14} N\right)$. The isotopic composition of nitrogen can be altered by fractionation, diffusion, dissolution of gaseous nitrogen in water, volatilization of ammonia, ion exchange, oxidation, reduction, and assimilation (Kreitler, 1975; Kendall and Aravena, 2000). Denitrification of $\mathrm{NO}_{3}$ yields residual $\mathrm{NO}_{3}$ enriched in ${ }^{15} \mathrm{~N}$. The $\delta^{15} \mathrm{~N}$ values of $\mathrm{NO}_{3}$ derived from a given source may vary; nevertheless, $\delta{ }^{15} \mathrm{~N}$ measurements of ground-water $\mathrm{NO}_{3}$ can be used in some situations to distinguish several local identifiable sources (Kreitler, 1975; Gormly and Spalding, 1979; Heaton, 1986). The $\delta^{15} \mathrm{~N}$ value is about 0 per mil for atmospheric $\mathrm{NO}_{3}$, generally ranges from about 2 to 9 per mil for natural soil $\mathrm{NO}_{3}$, and is generally greater than 9 per mil for animal/human waste sources (Kreitler, 1975; Gormly and Spalding, 1979).
Soil samples from the Warren ground-water basin had total-nitrogen concentrations ranging from 116 to $189 \mathrm{mg} / \mathrm{kg}$, leachable $\mathrm{NO}_{3}-\mathrm{N}$ (nitrate reported as nitrogen) concentrations ranging from 2 to 11 $\mathrm{mg} / \mathrm{kg}$. The $\delta{ }^{15} \mathrm{~N}$ values of the salt in the dried soil samples were determined by mass spectrometry on $\mathrm{N}_{2}$ gas produced by combustion of sample aliquots with $\mathrm{Cu}_{2} \mathrm{O}$. Aliquots of the dried soil samples were leached with deionized water to remove the soluble inorganic fraction of nitrogen, from which the concentrations and $\delta{ }^{15} \mathrm{~N}$ values of leachable $\mathrm{NO}_{3}-\mathrm{N}$ fractions were determined. The $\delta{ }^{15} \mathrm{~N}$ values for the soil leachate samples ranged from 3.60 to 6.70 per mil (table 3). In the Bicycle Lake Basin, where natural-soil $\mathrm{NO}_{3}$ was identified as the primary source of ground-water $\mathrm{NO}_{3}$, the leachable $\mathrm{NO}_{3}-\mathrm{N}$ concentrations were much higher than those found in the Warren ground-water basin, ranging from 196 to 2,395 mg/kg (Densmore and Böhlke, 2000).

The $\delta{ }^{15} \mathrm{~N}$ values for ground-water samples from wells in the Warren ground-water basin and for septage samples collected from suction-cup lysimeters in Victorville, California, are shown in figure 19 and presented in table 6 . The $\delta{ }^{15} \mathrm{~N}$ values ranged from 0.19 to 9.90 per mil for the ground-water samples and from 7.10 to 14.80 per mil for the septage samples. A majority of the ground-water samples had $\delta{ }^{15} \mathrm{~N}$ values greater than or equal to the highest $\delta{ }^{15} \mathrm{~N}$ value of the soil-leachate samples (6.70 per mil, table 3$)$ indicating that they were influenced by septage (fig. 19). In addition, samples from all of the wells in the midwest and mideast hydrogeologic units that had $\mathrm{NO}_{3}$ concentrations greater than $44 \mathrm{mg} / \mathrm{L}$ also had $\delta{ }^{15} \mathrm{~N}$ values greater than or equal to 6.25 per mil, indicating that the high $-\mathrm{NO}_{3}$ concentrations were probably influenced by septage. The samples that had $\delta{ }^{15} \mathrm{~N}$ values less than 6.00 per mil [1N/5E-34K2 $(2 \mathrm{~W})$, 1S/5E-3D1 (8W), 1N/5E-34Q2 (9W), 1N/5E-36G1 (YV1-570), 1N/5E-36H2 (18E), and 1N/6E-31C1 (5E)], had $\mathrm{NO}_{3}$ concentrations less than $15 \mathrm{mg} / \mathrm{L}$ (nearbackground concentration), indicating that these wells were probably not influenced by septage. 
Table 6. Analyses of nitrate as nitrate, nitrogen isotope, dissolved organic carbon and fluorescence from selected wells in Warren ground-water basin and lysimeters in Victorville, California

$\left[\mathrm{mg} / \mathrm{L}\right.$, milligrams per liter; per mil, parts per thousand; $\delta^{15} \mathrm{~N}$, nitrogen isotope; —, no data]

\begin{tabular}{|c|c|c|c|c|c|c|}
\hline State well No. & Local name & Date & $\begin{array}{l}\text { Nitrate as nitrate } \\
\quad(\mathrm{mg} / \mathrm{L})\end{array}$ & $\begin{array}{c}\delta^{15} \mathrm{~N} \\
\text { (per mil) }\end{array}$ & $\begin{array}{c}\text { Dissolved } \\
\text { organic carbon } \\
\text { (mg/L) }\end{array}$ & Fluorescence \\
\hline \multicolumn{7}{|c|}{ Warren ground-water basin sites } \\
\hline $1 \mathrm{~N} / 5 \mathrm{E}-34 \mathrm{~K} 2$ & $2 \mathrm{~W}$ & $3 / 25 / 98$ & 14.2 & 0.19 & - & - \\
\hline $1 \mathrm{~N} / 5 \mathrm{E}-34 \mathrm{~K} 2$ & & $7 / 10 / 01$ & 13.8 & - & - & - \\
\hline 1N/5E-34Q2 & $9 \mathrm{~W}$ & $4 / 15 / 99$ & 10.9 & 4.9 & 0.187 & 0.65 \\
\hline 1N/5E-34Q2 & & $8 / 27 / 01$ & 14.4 & 5.86 & - & - \\
\hline $1 \mathrm{~N} / 5 \mathrm{E}-35 \mathrm{P} 1$ & $3 \mathrm{~W}$ & $3 / 25 / 98$ & 21.1 & 7.0 & - & - \\
\hline $1 \mathrm{~N} / 5 \mathrm{E}-35 \mathrm{P} 1$ & & $4 / 14 / 99$ & 23.6 & 7.22 & .268 & 1.64 \\
\hline 1N/5E-36G1 & YV1-570 & $6 / 10 / 98$ & 10.1 & 3.93 & .07 & .05 \\
\hline 1N/5E-36G1 & & $8 / 28 / 01$ & 9.4 & - & - & - \\
\hline $1 \mathrm{~N} / 5 \mathrm{E}-36 \mathrm{G} 2$ & YV1-400 & $3 / 25 / 98$ & 103.7 & 7.23 & - & - \\
\hline $1 \mathrm{~N} / 5 \mathrm{E}-36 \mathrm{G} 2$ & & $6 / 10 / 98$ & 84.6 & 7.09 & .46 & 1.2 \\
\hline $1 \mathrm{~N} / 5 \mathrm{E}-36 \mathrm{G} 2$ & & $8 / 27 / 01$ & 76.6 & - & - & - \\
\hline $1 \mathrm{~N} / 5 \mathrm{E}-36 \mathrm{G} 3$ & YV1-305 & $6 / 12 / 98$ & 124.0 & 7.1 & .45 & 1.2 \\
\hline $1 \mathrm{~N} / 5 \mathrm{E}-36 \mathrm{G} 3$ & & $8 / 28 / 01$ & 35.0 & 7.44 & - & - \\
\hline $1 \mathrm{~N} / 5 \mathrm{E}-36 \mathrm{G} 4$ & YV1-230 & $3 / 25 / 98$ & 109.9 & 7.02 & - & - \\
\hline $1 \mathrm{~N} / 5 \mathrm{E}-36 \mathrm{G} 4$ & & $6 / 12 / 98$ & 106.3 & 7.13 & .58 & 1.5 \\
\hline 1N/5E-36G4 & & $8 / 28 / 01$ & 14.4 & 7.38 & - & - \\
\hline $1 \mathrm{~N} / 5 \mathrm{E}-36 \mathrm{H} 2$ & $18 \mathrm{E}$ & $3 / 25 / 98$ & 10.0 & 3.76 & - & .12 \\
\hline $1 \mathrm{~N} / 5 \mathrm{E}-36 \mathrm{H} 2$ & & 4/14/99 & 9.0 & 3.95 & .124 & 1.28 \\
\hline $1 \mathrm{~N} / 5 \mathrm{E}-36 \mathrm{~K} 2$ & $9 \mathrm{E}$ & $3 / 24 / 98$ & 38.1 & 6.84 & - & - \\
\hline $1 \mathrm{~N} / 5 \mathrm{E}-36 \mathrm{~K} 2$ & & 4/12/99 & 30.6 & 6.88 & .304 & 2.01 \\
\hline $1 \mathrm{~N} / 5 \mathrm{E}-36 \mathrm{~K} 3$ & $14 \mathrm{E}$ & 4/14/99 & 23.4 & 6.39 & .642 & 1.62 \\
\hline $1 \mathrm{~N} / 5 \mathrm{E}-36 \mathrm{~K} 3$ & & $7 / 11 / 01$ & 20.7 & 6.7 & - & - \\
\hline 1N/5E-36L1 & $7 \mathrm{E}$ & $3 / 24 / 98$ & 52.7 & 6.43 & - & 2.79 \\
\hline 1N/5E-36L1 & & $7 / 10 / 01$ & 25.2 & 6.57 & - & - \\
\hline $1 \mathrm{~N} / 5 \mathrm{E}-36 \mathrm{M} 1$ & YV2-570 & $6 / 12 / 98$ & 49.6 & 6.25 & .59 & .08 \\
\hline $1 \mathrm{~N} / 5 \mathrm{E}-36 \mathrm{M} 1$ & & $8 / 29 / 01$ & 82.0 & 6.3 & - & - \\
\hline $1 \mathrm{~N} / 5 \mathrm{E}-36 \mathrm{M} 2$ & YV2-390 & $6 / 11 / 98$ & 10.3 & 6.94 & .73 & 2.6 \\
\hline $1 \mathrm{~N} / 5 \mathrm{E}-36 \mathrm{M} 2$ & & $8 / 29 / 01$ & 20.8 & - & - & - \\
\hline $1 \mathrm{~N} / 5 \mathrm{E}-36 \mathrm{M} 3$ & YV2-300 & $3 / 24 / 98$ & - & 8.16 & - & - \\
\hline $1 \mathrm{~N} / 5 \mathrm{E}-36 \mathrm{M} 3$ & & $6 / 11 / 98$ & 20.1 & 6.66 & .73 & 3.5 \\
\hline $1 \mathrm{~N} / 5 \mathrm{E}-36 \mathrm{M} 3$ & & $8 / 29 / 01$ & 3.6 & - & - & - \\
\hline $1 \mathrm{~N} / 5 \mathrm{E}-36 \mathrm{M} 4$ & $12 \mathrm{E}$ & $4 / 5 / 00$ & 45.6 & 6.58 & - & - \\
\hline $1 \mathrm{~N} / 5 \mathrm{E}-36 \mathrm{M} 5$ & $16 \mathrm{E}$ & $3 / 24 / 98$ & 10.2 & 7.25 & - & - \\
\hline $1 \mathrm{~N} / 5 \mathrm{E}-36 \mathrm{M} 5$ & & $4 / 14 / 99$ & 9.7 & 7.11 & .108 & 2.93 \\
\hline $1 \mathrm{~N} / 5 \mathrm{E}-36 \mathrm{M} 6$ & $17 \mathrm{E}$ & $3 / 24 / 98$ & 53.6 & 6.56 & - & - \\
\hline $1 \mathrm{~N} / 5 \mathrm{E}-36 \mathrm{M} 6$ & & $7 / 10 / 01$ & 54.9 & 6.68 & - & - \\
\hline 1S/5E-3D1 & $8 \mathrm{~W}$ & $4 / 15 / 99$ & 8.1 & 8.93 & .21 & 1.02 \\
\hline 1S/5E-3D1 & & $4 / 5 / 00$ & 8.4 & 6.7 & - & - \\
\hline 1S/5E-3D1 & & $8 / 27 / 01$ & 9.8 & 4.89 & - & - \\
\hline 1S/5E-4A1 & BSGC 17 & 4/13/99 & 19.6 & 9.9 & .172 & 2.25 \\
\hline 1S/5E-4A1 & & $7 / 11 / 01$ & 20.6 & 9.75 & - & - \\
\hline $1 \mathrm{~N} / 6 \mathrm{E}-31 \mathrm{C} 1$ & $5 \mathrm{E}$ & $4 / 12 / 99$ & 11.5 & 5.78 & .173 & 1.87 \\
\hline
\end{tabular}


Table 6. Analyses of nitrate, nitrogen isotope, dissolved organic carbon and fluorescence from selected wells in Warren ground-water basin and lysimeters in Victorville, California-Continued

\begin{tabular}{|c|c|c|c|c|c|c|}
\hline State well No. & Local name & Date & $\begin{array}{l}\text { Nitrate as nitrate } \\
\quad(\mathrm{mg} / \mathrm{L})\end{array}$ & $\begin{array}{c}\delta^{15} \mathrm{~N} \\
\text { (per mil) }\end{array}$ & $\begin{array}{c}\text { Dissolved } \\
\text { organic carbon } \\
\text { (mg/L) }\end{array}$ & Fluorescence \\
\hline Lysimeter samples & & & Victor Valley sit & & & \\
\hline 4N/4W-23F1LYS & Cajon@257 & $5 / 13 / 98$ & 0.2 & - & - & - \\
\hline 4N/4W-23F1LYS & & $5 / 14 / 98$ & .2 & - & 1.2 & 3.5 \\
\hline 4N/4W-23F2LYS & Cajon@243 & $6 / 12 / 90$ & 3.5 & 7.1 & - & - \\
\hline 4N/4W-23F2LYS & & $5 / 13 / 98$ & 11.0 & - & 2.02 & 8 \\
\hline 4N/4W-23F3LYS & Cajon@199 & $11 / 13 / 91$ & 114.3 & 14.8 & - & - \\
\hline 4N/4W-23F3LYS & & $5 / 13 / 98$ & 28.0 & - & - & - \\
\hline 4N/4W-23F3LYS & & $5 / 14 / 98$ & 54.5 & - & 3.51 & 8.8 \\
\hline 4N/4W-23F4LYS & Cajon@160 & $5 / 14 / 98$ & 94.8 & - & 2.48 & 5.8 \\
\hline 4N/4W-23F5LYS & Cajon@130 & $5 / 14 / 98$ & 109.9 & - & 1.84 & 6.3 \\
\hline 4N/4W-23F6LYS & Cajon@97.5 & $5 / 13 / 98$ & 128.9 & - & - & - \\
\hline 4N/4W-23F6LYS & & $5 / 14 / 98$ & 161.7 & - & 1.17 & 7 \\
\hline 4N/4W-23F7LYS & Cajon@70 & $5 / 13 / 98$ & 106.3 & - & - & - \\
\hline 4N/4W-23F7LYS & & $5 / 14 / 98$ & 136.9 & - & 1.3 & 9.3 \\
\hline 4N/4W-23F8LYS & Cajon@35 & $5 / 13 / 98$ & 109.0 & - & - & - \\
\hline 4N/4W-23F8LYS & & $5 / 14 / 98$ & 222.8 & - & 1.79 & 12.1 \\
\hline $5 \mathrm{~N} / 3 \mathrm{~W}-16 \mathrm{E} 1 \mathrm{LYS}$ & Cheyenne @ 113 & $5 / 13 / 98$ & 181.2 & - & - & - \\
\hline $5 \mathrm{~N} / 3 \mathrm{~W}-16 \mathrm{E} 1 \mathrm{LYS}$ & & $5 / 14 / 98$ & 134.7 & - & 1.05 & 3.8 \\
\hline $5 \mathrm{~N} / 3 \mathrm{~W}-16 \mathrm{E} 2 \mathrm{LYS}$ & Cheyenne@92.5 & $7 / 20 / 89$ & 141.8 & 7.8 & - & - \\
\hline $5 \mathrm{~N} / 3 \mathrm{~W}-16 \mathrm{E} 2 \mathrm{LYS}$ & & $5 / 14 / 98$ & 78.0 & - & 3.5 & 11.3 \\
\hline 5N/3W-16E3LYS & Cheyenne@37 & $7 / 20 / 89$ & 141.8 & 8.7 & - & - \\
\hline 5N/3W-16E3LYS & & $5 / 14 / 98$ & 88.6 & - & 2.1 & 15.4 \\
\hline 5N/3W-16E8LYS & Cheyenne@106 & $5 / 14 / 98$ & - & - & 12.3 & - \\
\hline 5N/3W-16E9LYS & Cheyenne@73 & $7 / 21 / 89$ & 155.1 & 8.3 & - & - \\
\hline 5N/3W-16E9LYS & & $5 / 14 / 98$ & - & - & 5.83 & 21.1 \\
\hline $5 \mathrm{~N} / 3 \mathrm{~W}-16 \mathrm{E} 10 \mathrm{LYS}$ & Cheyenne@63 & $7 / 20 / 89$ & 137.3 & 8.7 & - & - \\
\hline $5 \mathrm{~N} / 3 \mathrm{~W}-16 \mathrm{E} 10 \mathrm{LYS}$ & & $5 / 13 / 98$ & 78.9 & - & - & - \\
\hline $5 \mathrm{~N} / 3 \mathrm{~W}-16 \mathrm{E} 10 \mathrm{LYS}$ & & $5 / 14 / 98$ & 73.5 & - & 1.18 & 6.7 \\
\hline 5N/3W-16E11LYS & Cheyenne@42 & $7 / 23 / 89$ & 168.3 & 7.9 & - & - \\
\hline 5N/3W-16E11LYS & & $5 / 14 / 98$ & 58.5 & - & 1.71 & 10.7 \\
\hline SEPTIC AT CHEYENNE & & $5 / 14 / 98$ & .2 & - & 11.8 & 32.1 \\
\hline
\end{tabular}




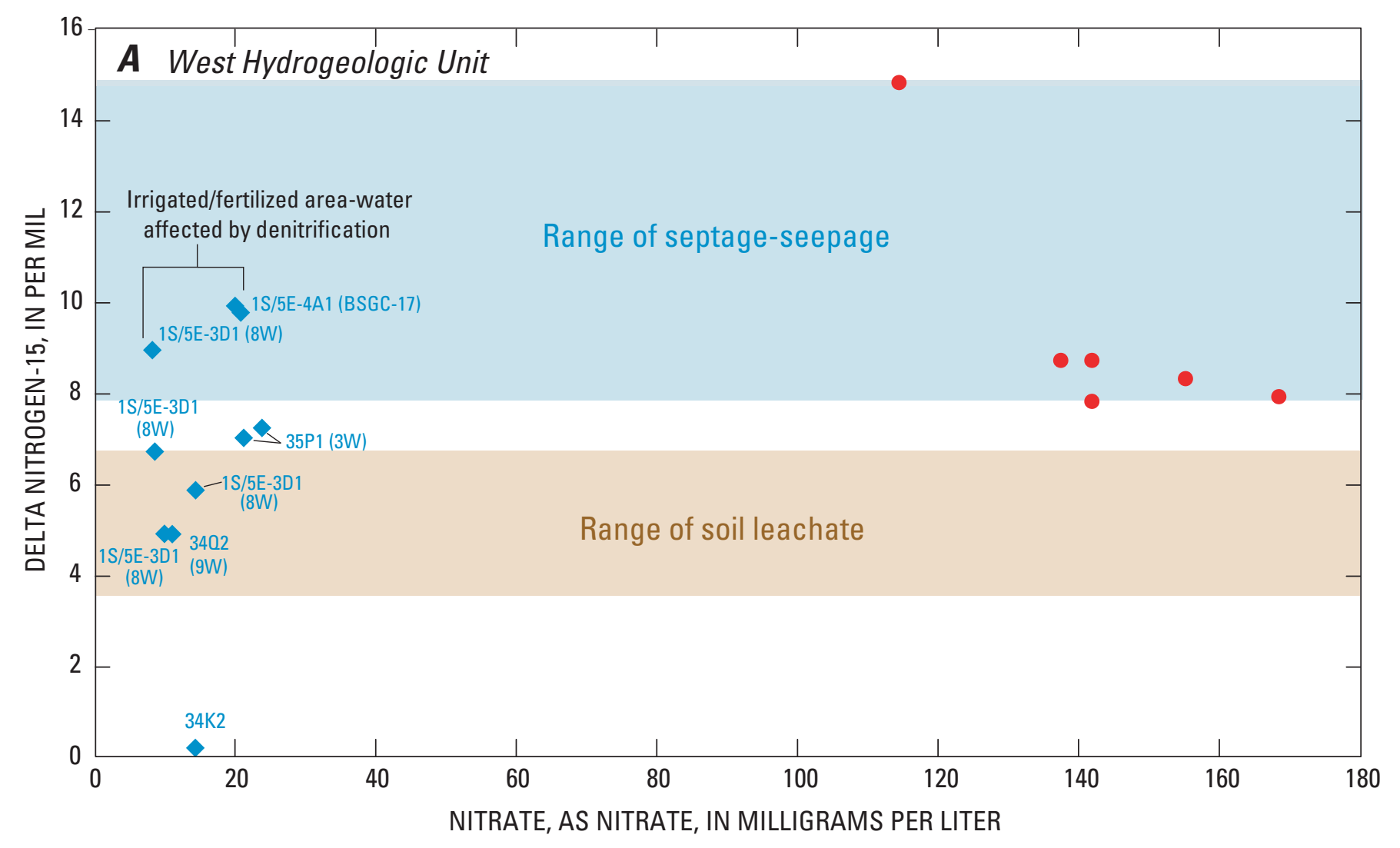

\section{EXPLANATION}

(Wells in 1N/5E unless otherwise noted)

Wells in the west
hydrogeologic unit
- Septage samples-

Victorville, California

Figure 19. Nitrogen isotope concentrations from ground-water samples from selected wells in the $(A)$ west, $(B)$ midwest, and $(C)$ mideast and northeast hydrogeologic units, Warren ground-water basin, San Bernardino County, California and septage samples from Victorville, California. 


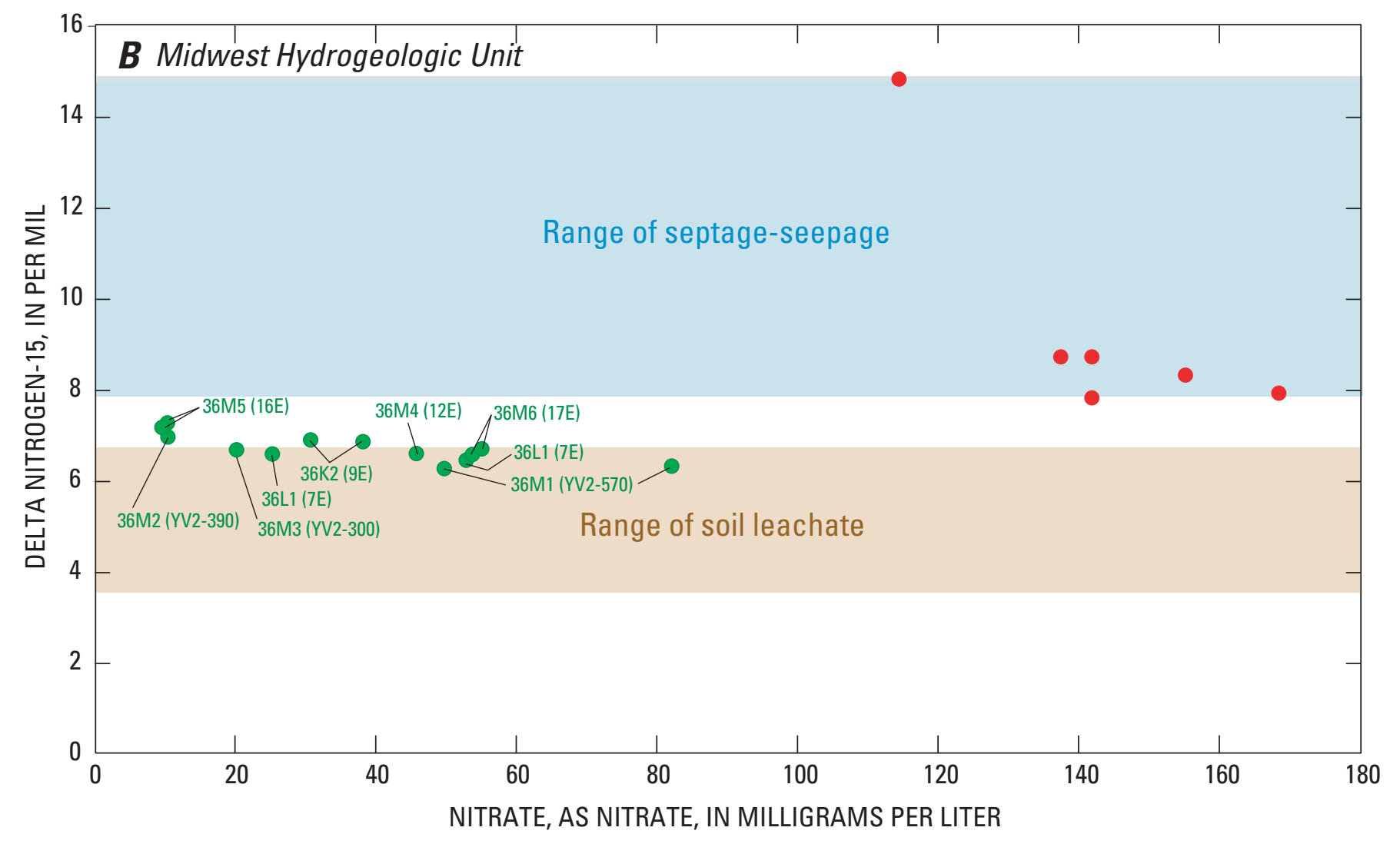

EXPLANATION

(Wells in $1 \mathrm{~N} / 5 \mathrm{E}$ )

- Wells in the midwest hydrogeologic unit
- Septage samples-

Victorville, California

Figure 19. - Continued. 


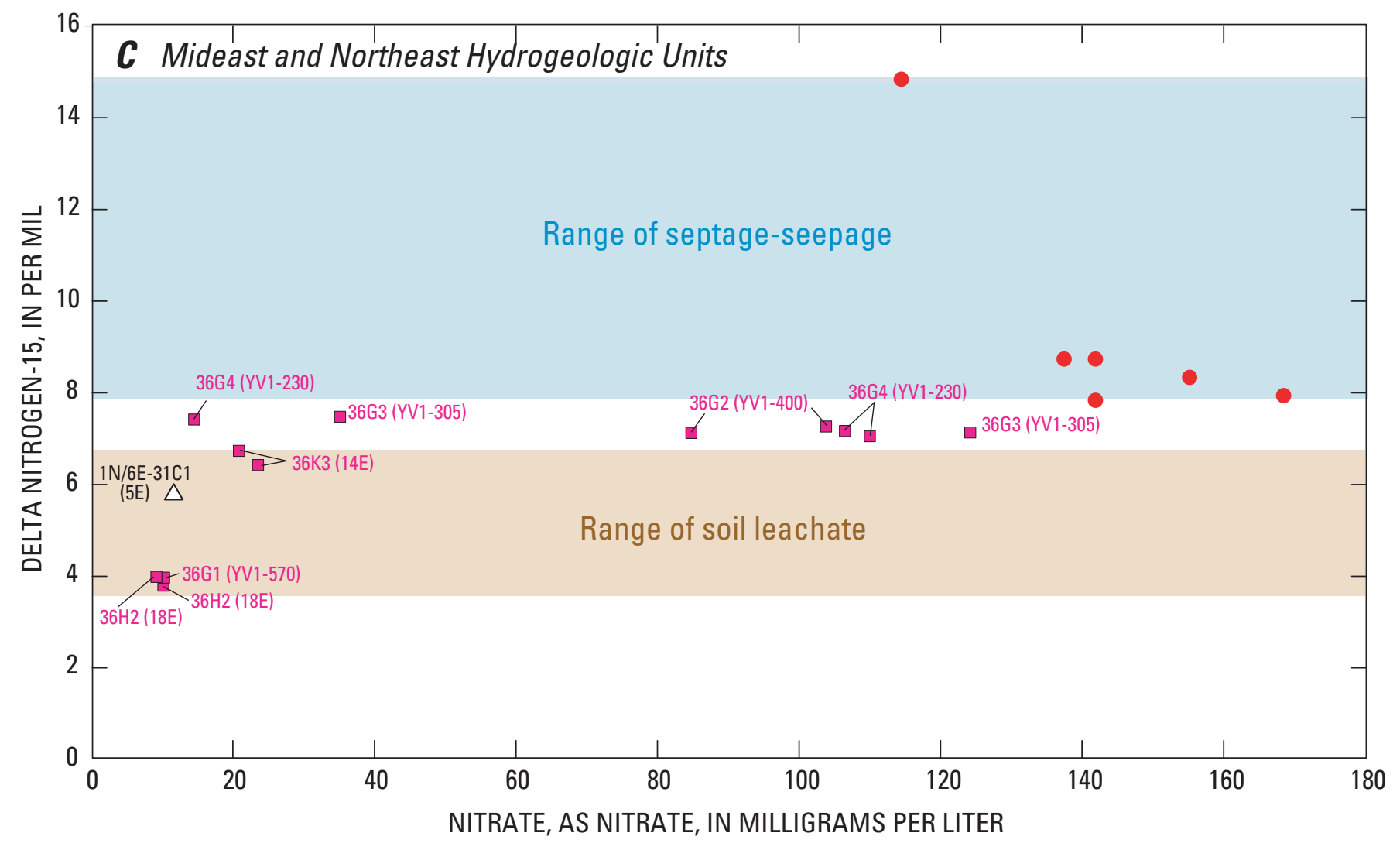

\section{EXPLANATION}

(Wells in 1N/5E unless otherwise noted)

Wells in the mideast hydrogeologic unit

\section{$\triangle$ Well in the northeast hydrogeologic unit}

Septage samples-
Victorville, California

Figure 19. - Continued. 


\section{Dissolved Organic Carbon and Fluorescence}

Concentrations of dissolved organic carbon (DOC) and fluorescence above background values are indicators of wastewater contamination (Barber and others, 1997; Leenheer and others, 2001). DOC is produced by bacteria decomposing the sludge that accumulates at the bottom of a septic tank. Fluorescent substances can occur naturally in soil but fluorescent compounds also are added to detergents as whitening agents (Larry B. Barber, U.S. Geological Survey, written commun., 1999). The fluorescence concentration may rapidly and inexpensively be determined by optical techniques; however, fluorescence has been used with mixed results to detect septic-tank contamination (Thrailkill and others, 1985; Harkin and others, 1990). For example, Thrailkill and others (1985) reported that in a karst (limestone) environment, fluorescence may be a reliable indicator of human contamination, whereas Harkin and others (1990), in a study of septic contamination in Wisconsin, reported that fluorescence did not pass through septic system drainfields.

Fourteen samples were collected from two sites in Victorville, California, where suction-cup lysimeters were installed at multiple depths in a thick (greater than $110 \mathrm{ft}$ ) unsaturated zone beneath active septic tanks. In addition, one sample was collected from a septic tank in the Victorville area (the Cheyenne site). The data were used to determine whether fluorescence could be used as an indicator of septic-tank contamination in a desert environment. Fluorescence values and DOC concentrations for samples from a septic tank and of septage from Victorville (Cheyenne and Cajon sites in fig. 20A) ranged from 3.5 to 32.1 and from 1 to 12 $\mathrm{mg} / \mathrm{L}$, respectively (table 6). These data indicate that fluorescence was detectable at depths of more than 240 $\mathrm{ft}$ below land surface; however, the fluorescence values and DOC concentrations were much lower than the septic-tank sample. The data also show a strong relationship between DOC and fluorescence, indicating the influence of septage on the samples (fig. 20A).

Sixteen samples collected from the Warren ground-water basin were analyzed for DOC and fluorescence (fig. 20B, table 6). Figure 20B shows poor correlation between fluorescence and DOC for groundwater samples from wells in the Warren ground-water basin. A possible explanation for this poor correlation may be that the unsaturated zone in the Warren groundwater basin is thicker than that at Victorville; thereby allowing greater degradation and (or) adsorption of fluorescence and DOC in the unsaturated zone. These data indicate that fluorescence values and DOC cannot be used to determine the source of $\mathrm{NO}_{3}$ contamination in the Warren ground-water basin.

\section{Caffeine and Pharmaceutical Analyses}

The detection of widely used chemicals such as caffeine or human pharmaceutical products (such as acetaminophen, ibuprofen, codeine, erythromycin, and other prescription and nonprescription drugs) along with elevated $\mathrm{NO}_{3}$ concentrations clearly indicate that domestic wastewater is a source of some of the $\mathrm{NO}_{3}$; however, the absence of caffeine or human pharmaceutical products does not show that the aquifer is free of domestic wastewater contamination (Seiler and others, 1999). Measured concentrations of caffeine or human pharmaceutical products are usually very low and, until recently, there have been few analytical techniques capable of detecting these compounds at low concentrations. Samples from four wells in the Warren ground-water basin were analyzed for caffeine and selected human pharmaceutical products. Of the four samples collected for this study and analyzed using liquid chromatography-mass spectrometry, two samples contained caffeine, two samples contained Sulfamethoxazole (an antibiotic), and two samples contained Carbamazapine (an anticonvulsant/mood stabilizer). All detections were at concentrations below defined lab reporting levels $(0.0161 \mu \mathrm{g} / \mathrm{L}$ for caffeine, $0.0641 \mu \mathrm{g} / \mathrm{L}$ for Sulfamethoxazole, and $0.0107 \mu \mathrm{g} / \mathrm{L}$ for Carbamazapine) but were identified as being present by their chromatography and mass spectra (Jeff Cahill, U.S. Geological Survey, written commun., 2001). The statement that detections were below defined lab reporting levels means that the concentrations reported fall outside of the statistical significance that has been established; these values would be estimated concentrations at best. However, it can be reported that the compounds were detected in the samples because the signal peaks for those compounds were chromatographically correct and their mass spectra were in agreement for that compound. 

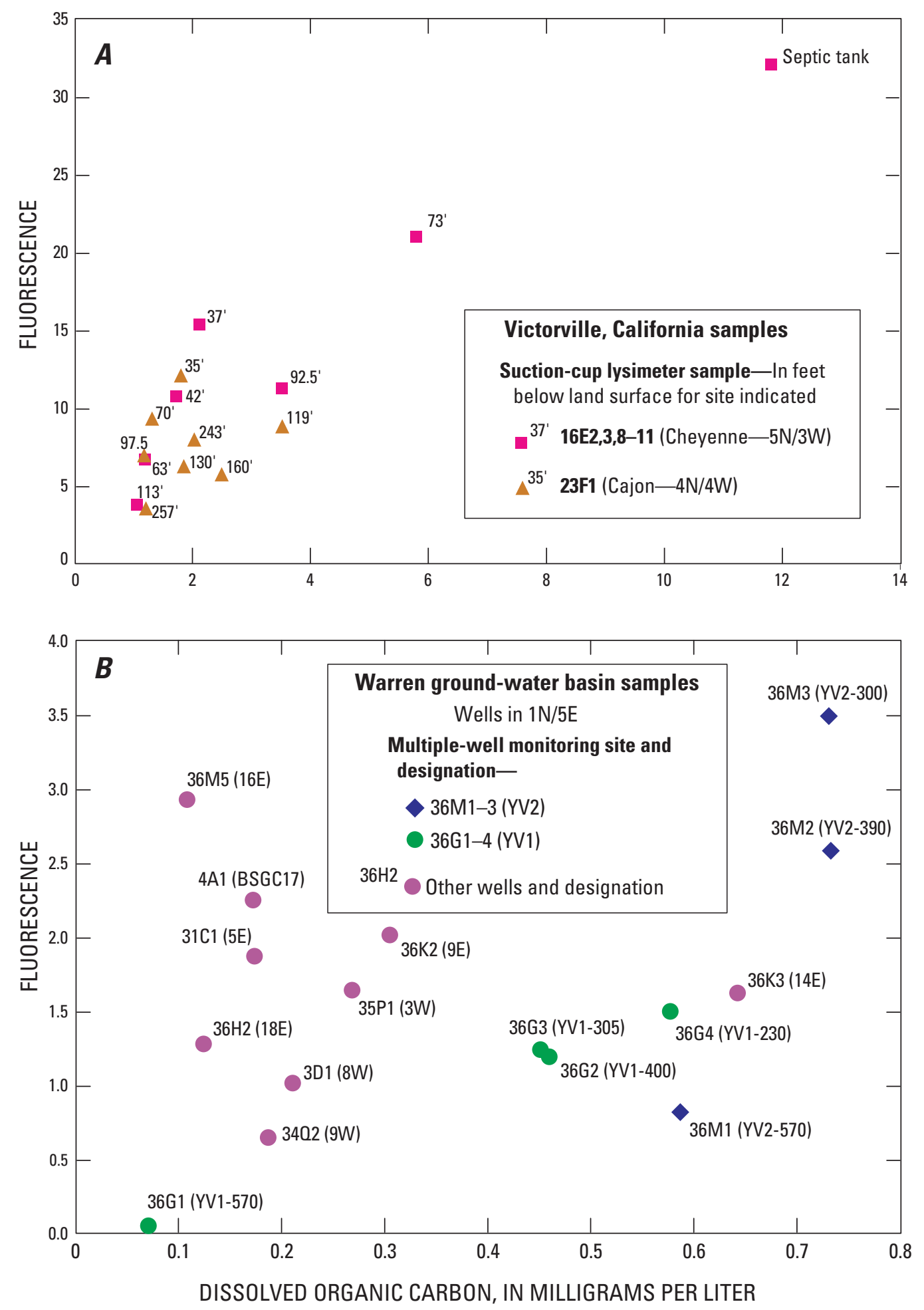

Figure 20. Relation between fluorescence and dissolved organic carbon in samples of: $(A)$ septage and septic-tank water at Victorville, California (Number at data point indicates depth at which sample was collected) and (B) ground water at Warren groundwater basin, San Bernardino County, California. 
The two detections of caffeine were in samples collected from wells 1N/5E-36G3 (YV1-305) and 1S/5E-4A1 (BSGC17). The sample from well 1N/5E36M6 (17E) had a detection for Sulfamethoxazole, the sample from well 1N/5E-34K1 (2W) had a detection for Carbamazapine, and the sample from well 36G3 had detections for Sulfamethoxazole and Carbamazapine. Carbamazapine has shown to be a persistent compound for which this method is very sensitive, and it is found in almost all the waters associated with human waste (Jeff Cahill, U.S. Geological Survey, written commun., 2001). Sulfamethoxazole is not as persistent as Carbamazapine and would not ordinarily be expected even at low levels without other human or animal pharmaceuticals being present (Jeff Cahill, U.S. Geological Survey, written commun., 2001). Although not definitive proof that septage was the source of increased $\mathrm{NO}_{3}$ concentrations, these data suggest that septage probably was reaching the water table in the Warren ground-water basin.

\section{Conceptual Model of Nitrate Transport}

Septic tanks are the only mode of wastewater treatment in the Warren ground-water basin. The total volume of septage infiltrating into the ground-water system was estimated from land-use maps and assumed wastewater loads for different land-use types (table 2). The 1952-53 land-use map was used to estimate the distribution of septage and irrigation return flow for the period 1956-64; the 1965 land-use map was used for the period 1965-76; the 1977 land-use map was used for the period 1977-89; and the 1993 land-use map was used for the period 1990-2001. The total volume of septage infiltrating into the ground-water system between 1956 and 1994 was estimated to equal 41,600 acre-ft. For comparative purposes, the total volume of natural recharge was probably less than 7,800 acre-ft (Lewis, 1972) and the total volume of pumpage for this period was about 64,000 acre-ft.
Data analyses presented in the previous sections of this report indicate that septage was the primary source of the high- $\mathrm{NO}_{3}$ concentrations measured in Warren ground-water basin wells. Water-quality and stable-isotope data, collected after the start of the artificial recharge program, indicate that mixing had occurred between imported water and native ground water in ground-water samples with the highest recorded $\mathrm{NO}_{3}$ concentrations in the midwest and mideast hydrogeologic units. In general, the timing of the increase in measured $\mathrm{NO}_{3}$ concentrations in the midwest hydrogeologic unit was directly related to the well's distance from recharge site 6 , indicating that the increase in $\mathrm{NO}_{3}$ concentrations was related to the artificial recharge program. Nitrate-to-chloride and nitrogen-isotope data indicate that septage was the source of the measured increase in $\mathrm{NO}_{3}$ concentrations in the midwest and mideast hydrogeologic units. Samples from four wells in the Warren ground-water basin were analyzed for caffeine and selected human pharmaceutical products; these analyses also suggest that septage was reaching the water table.

There are two possible mechanisms that explain how the high- $\mathrm{NO}_{3}$ septage reached the water table: (1) downward migration through the unsaturated zone to the water table (fig. 21A) or (2) rising water levels, a result of the artificial recharge program, entraining septage stored in the unsaturated zone (fig. $21 B$ ). Prior to the start of the artificial-recharge program, the septage slowly infiltrated into the underlying unsaturated sediments with the septage moving both downward beneath the septic tanks and laterally as layers with variable permeability and moisture content were encountered. Umari and others (1995) reported the vertical rate of a wastewater wetting front at a site in Victorville, California, ranged from 0.07 to $1 \mathrm{ft} / \mathrm{d}$, with the higher value in the upper part of the unsaturated zone. The assumption that these values represent travel times in the Warren ground-water basin and that the thickness of the unsaturated zone in the midwest hydrogeologic unit was about $430 \mathrm{ft}$ in 1994 yields a travel time of 1.2 to 17 years for the septage to reach the water table. 

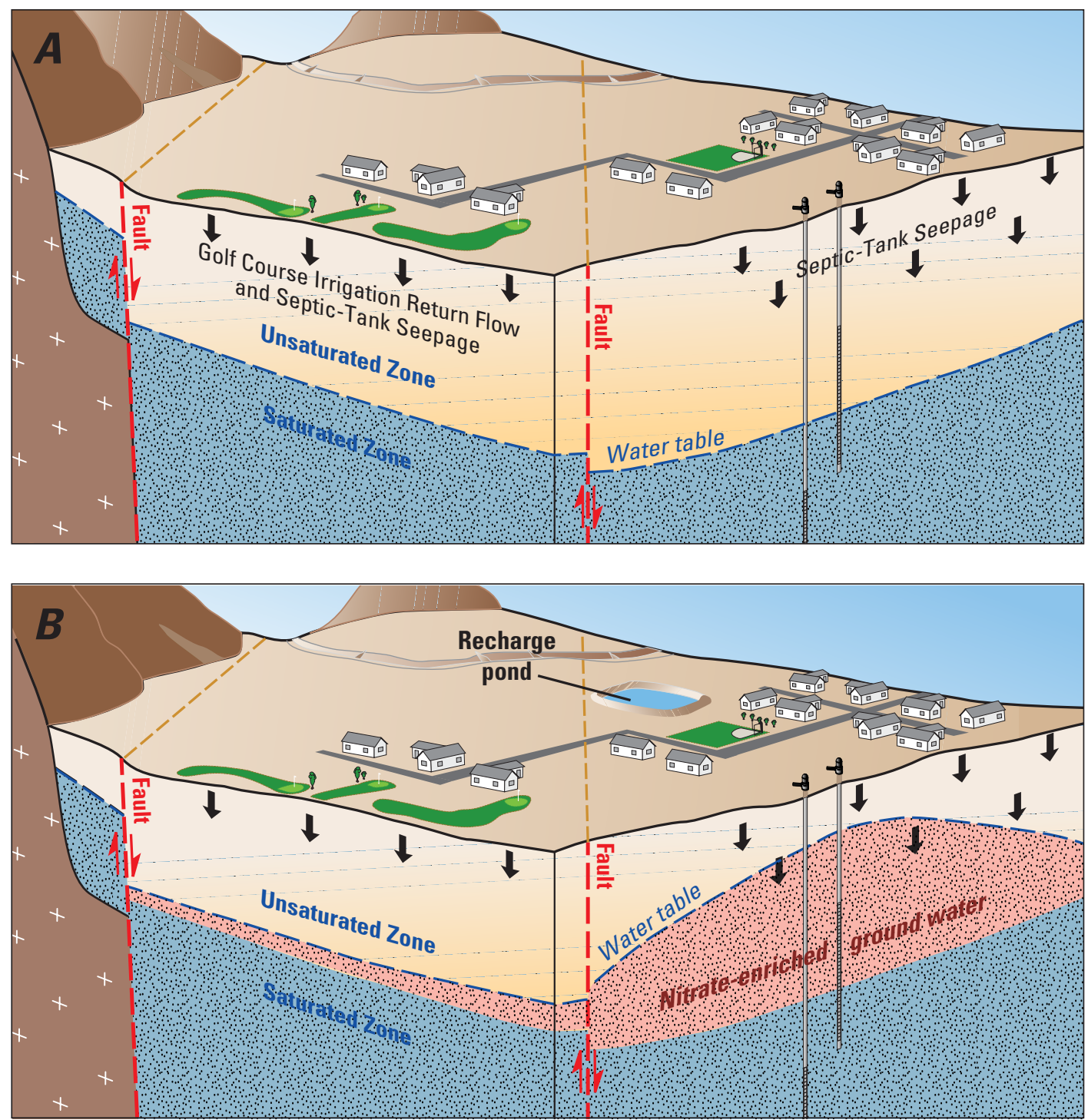

Figure 21. Conceptual model of septage entrainment: $(A)$ downward migration of septage in unsaturated zone prior to artificial-recharge operations and $(B)$ water-level rise entraining septage, Warren ground-water basin, San Bernardino County, California. 
By the late 1980s, the $\mathrm{NO}_{3}$ concentrations in samples from some wells perforated in the alluvial aquifer [1N/5E-35P1 (3W), 36L1 (7E), 36M4 (12E), $36 \mathrm{M} 6$ (17E), and 1N/6E-31C1(5E)] started to increase, and by 1994 were as high as $20 \mathrm{mg} / \mathrm{L}$. Assuming these travel time estimates, one might expect to observe increased $\mathrm{NO}_{3}$ concentrations earlier than the late 1980s. The absence of increased $\mathrm{NO}_{3}$ concentrations may be explained by a loss of $\mathrm{NO}_{3}$ present in the septage before it mixed into the ground water (denitrification), by the confinement of $\mathrm{NO}_{3}$ to unsampled shallow depths below the water table, by the storage of septage in the unsaturated zone, or by the significant underestimation [by Umari and others (1993)] of the vertical rate of the wetting front. Available data indicate that the $\mathrm{NO}_{3}$ concentration at the water table was low; therefore, the $\mathrm{NO}_{3}$ in the septage must have been removed by denitrification or stored in the unsaturated zone. The potential storage volume of the unsaturated zone beneath the groundwater basin is estimated to equal 158,000 acre-ft [multiplying the total area of these hydrogeologic units (3,500 acres) by the thickness of the unsaturated zone of $300 \mathrm{ft}$ and by the porosity of 0.3 minus an assumed moisture content of 0.15$]$; therefore, the total volume of infiltrated septage of 41,600 acre-ft could be stored in the unsaturated zone.

In early 1995, the artificial recharge program began with an almost immediate increase in water levels followed by a dramatic increase in $\mathrm{NO}_{3}$ concentrations (fig. 14). The rapid rise in water levels entrained the large volume of septage that was stored in the unsaturated zone (fig. 21B ), resulting in a rapid increase in $\mathrm{NO}_{3}$ concentrations. The potential $\mathrm{NO}_{3}$ concentration resulting from a water-level rise in the midwest and mideast hydrogeologic units was estimated using a simple mixing-cell model assuming $\mathrm{NO}_{3}$ in pore water is conserved (that is, absence of physical or chemical retardation of $\mathrm{NO}_{3}$ ):

$$
N O_{3}^{P}=\frac{V_{w} \cdot C_{s}}{V_{v}}+\frac{\left(V_{v}-V_{w}\right) \cdot C_{i}}{V_{v}}
$$

where $\mathrm{NO}_{3}^{P}$ is the potential $\mathrm{NO}_{3}$ load $\left(M L^{-3}\right), V_{w}$ is the volume of water in the pore space $\left(L^{3}\right)$ (the total volume multiplied by the moisture content), $C_{S}$ is the $\mathrm{NO}_{3}$ concentration for average septage $\left(M L^{-3}\right), V_{v}$ is the volume of the pore space $\left(L^{3}\right)$ (the total volume multiplied by the porosity), and $C_{i}$ is the $\mathrm{NO}_{3}$ concentration of native ground water $\left(M L^{-3}\right)$.

Equation 2 was applied to a representative acre of residential and commercial land use. There was about a 250-ft water-level rise during the five-year period of 1994-98 yielding a total volume of 250 acre$\mathrm{ft}$. It was assumed that the porosity equaled 0.3 , the moisture content beneath developed areas equaled 0.15 , the $\mathrm{NO}_{3}$ concentration for septage equaled $220 \mathrm{mg} / \mathrm{L}$, and the $\mathrm{NO}_{3}$ concentration for native ground water equaled $10 \mathrm{mg} / \mathrm{L}$. The volume of the pore space equals the total volume ( 250 acre-ft) multiplied by the porosity (0.3), giving, 75 acre-ft; and the estimated volume of water in the pore space equals the total volume ( 250 acre-ft) multiplied by the moisture content (0.15), giving, 37.5 acre-ft. Using equation 2, the potential $\mathrm{NO}_{3}$ load would equal about $115 \mathrm{mg} / \mathrm{L}$. This value is within the range of concentrations measured in samples collected from wells for this study indicating the validity of this conceptual model.

\section{GROUND-WATER FLOW AND SOLUTE- TRANSPORT MODELS}

To better understand the physics and dynamics of ground-water flow and solute transport in the Warren ground-water basin numerical flow and solute-transport models of the basin were developed for the period 1956-2001. These models can also be used to estimate the effects of water management alternatives on ground-water levels and $\mathrm{NO}_{3}$ concentrations. The ground-water flow model was developed using MODFLOW-96 (Harbaugh and McDonald, 1996) and the solute-transport model was developed using MOC3D (Konikow and others, 1996). 


\section{MODFLOW-96}

MODFLOW-96 is a finite-difference model that simulates ground-water flow in a three-dimensional heterogeneous and anisotropic medium provided that the principal axes of hydraulic conductivity are aligned with the coordinate directions and that the fluid has constant density (Harbaugh and McDonald, 1996). For additional information regarding MODFLOW-96, the reader is referred to McDonald and Harbaugh (1988) and Harbaugh and McDonald (1996).

\section{MOC3D}

MOC3D is a finite-difference model that simulates three-dimensional solute transport in flowing ground water. The model computes changes in concentration of a single dissolved chemical constituent over time that are caused by advective transport, hydrodynamic dispersion, dilution from fluid sources, and retardation (Konikow and others, 1996). MOC3D is integrated with MODFLOW-96 such that the head distribution for a given time step or steadystate flow condition is used to calculate the specific discharge, which, in turn, is used in the simulation of advective transport and hydrodynamic dispersion.

MOC3D solves the following governing equation:

$$
\begin{gathered}
\frac{\partial C}{\partial \mathrm{t}}+\frac{V_{i}}{R_{f}} \cdot \frac{\partial C}{\partial x_{i}}-\frac{1}{\varepsilon R_{f}} \cdot \frac{\partial}{\partial x_{i}} \cdot\left(\varepsilon \cdot D_{i j} \frac{\partial C}{\partial x_{j}}\right)- \\
\frac{\Sigma\left[W\left(C^{\prime}-C\right)\right]}{\varepsilon \cdot R_{f}}+\lambda C=0
\end{gathered}
$$

where:

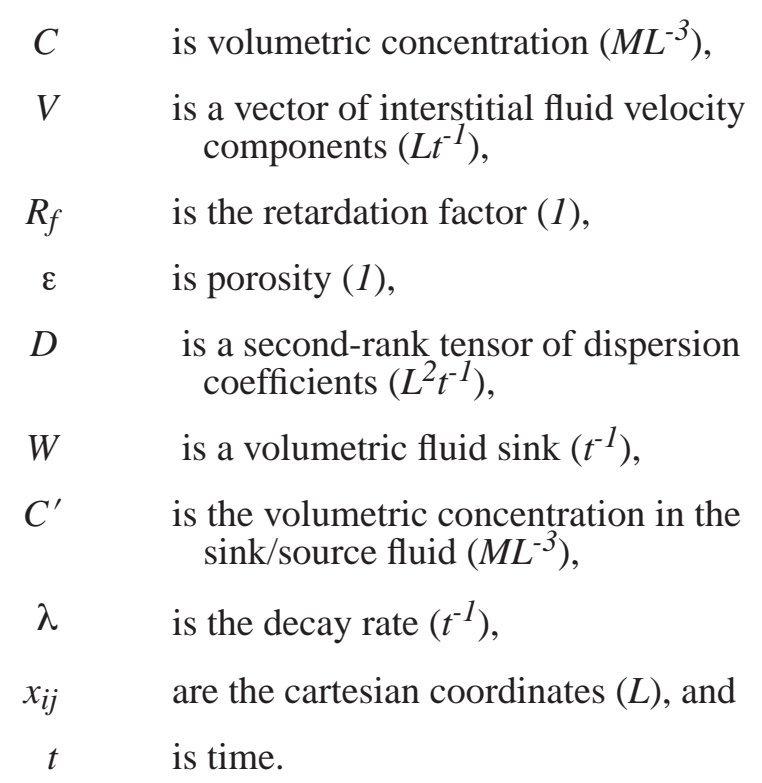

The second term from the left in equation 3 is the advective term and is solved using the method-ofcharacteristics coupled with particle tracking. The third term from the left in equation 3 is the hydrodynamic dispersion term and is solved using a centered-in-space and explicit finite-difference method. For additional information regarding MOC3D, the reader is referred to Konikow and others (1996).

\section{Model Discretization}

\section{Spatial Discretization}

MODFLOW-96 and MOC3D use the same finite-difference model grid (fig. 22). The horizontal and vertical grid spacing is about $500 \mathrm{ft}$ by $500 \mathrm{ft}$. The horizontal model domain was based initially on geohydrologic data collected by previous investigators and for this study. Estimates of average aquifer properties are assigned to the representative cell volume, and average hydraulic head and concentration were calculated at the center, or node, of each cell. 


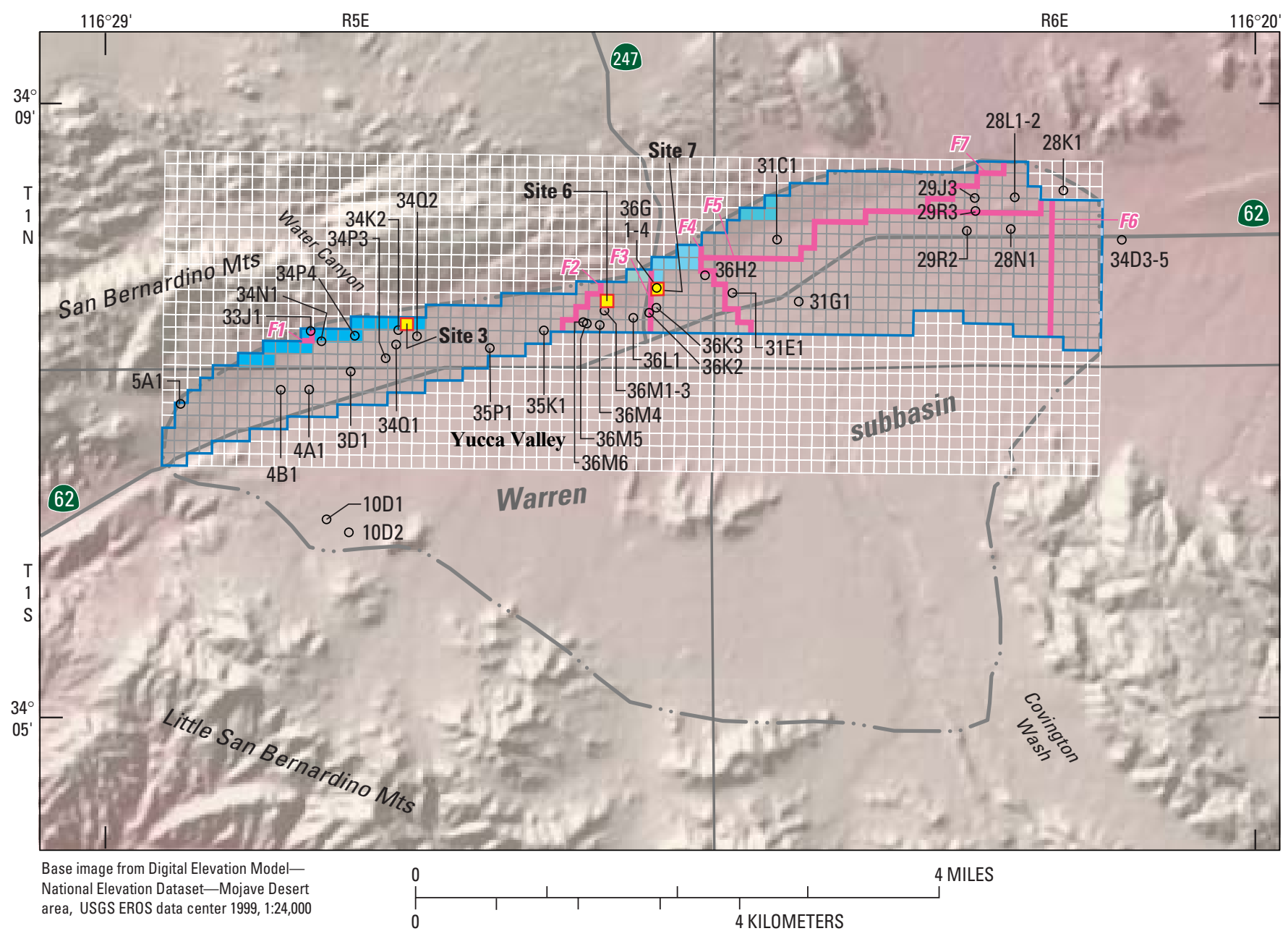

EXPLANATION

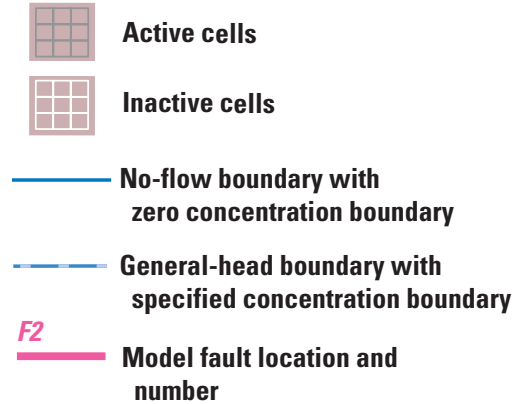

$\begin{array}{ll} & \text { Natural recharge cell- } \\ \text { Water Canyon } \\ \text { West Central } \\ \text { East Central } \\ \\ \text { Eastern } \\ \square \quad \text { Artificial recharge cell } \\ 0^{10 D 2} \text { Monitoring site and designation }\end{array}$

Figure 22. Model grid for the ground-water flow and solute-transport model of the Warren ground-water basin, San Bernardino County, California, showing active and inactive cells, modeled faults, natural recharge cells, artificial recharge cells, and general-head boundary. 
The vertical layering is shown along with the relative thicknesses and the altitudes of the model layers in figure 23. The aquifer system was vertically discretized into three horizontal layers; model layer 1 represents the upper and middle aquifers, model layer 2 represents the lower aquifer, and model layer 3 represents the deep aquifer. The upper and middle aquifers were combined into a single model layer because the upper aquifer becomes dewatered in response to pumpage and then becomes resaturated in response to the artificial recharge program. MOC3D does not have the capability to model a dewatered and then resaturated model layer (Konikow and others, 1996). The use of horizontal layers was reasonable because the layers coordinate well with the geologic contacts.

In most areas, the altitudes of the bottom of model layer 1 and the bottom of model layer 2 were assumed to be uniformly flat (ig. 23) and correspond with geologic contacts. The top altitude of model layer 1 represents the water table and was defined using data from a Digital Elevation Model (DEM) of the subbasin (Steven Predmore, U.S. Geological Survey, written commun., 2001); the bottom altitude corresponds to the bottom of the middle aquifer at $2,700 \mathrm{ft}$ above sea level, except in areas where the basement-complex elevation is greater than 2,700 ft. Model layer 2 is about $600 \mathrm{ft}$ thick; the bottom altitude corresponds to the bottom of the lower aquifer at $2,100 \mathrm{ft}$ above sea level, except where the basement-complex elevation is greater than $2,100 \mathrm{ft}$. If the basement-complex elevation is greater than the bottom of the model layer, then the model cell is inactive in that layer. Model layer 3 has a variable thickness; the bottom altitude is based on the depth to basement complex determined by gravity measurements (fig. 5). The bottom of model layer 3 was defined by depth-to-basement-complex data estimated by Roberts and others (2002) and Harding Lawson Associates (1984) using gravity measurements. It was assumed that the basement complex yields little to no water to the ground-water flow system.

\section{Temporal Discretization}

To simulate predevelopment conditions (no stresses), ground-water flow and solute transport were simulated for 10,000 years to allow the flow and concentration fields to equilibrate to specified initial and boundary conditions in one-year time steps. The temporal discretization was deemed adequate because the mass balance errors for both models were small ( 0.0 percent for the flow model and -0.7 percent for the solute transport model) and the simulated hydraulic heads had reached an equilibrium after 10,000 years (fig. 24). Although the time-varying simulated hydraulic heads appear to be decreasing at 10,000 years, the percentage change from 9,500 years to 10,000 years was less than 0.1 percent.

The period of 1956-2001 was simulated in two parts; one simulation from 1956 to 1994 and another from 1995 to 2001. Two simulations were made because only annual pumping data were available for 1956-94, while monthly data were available for 1995-2001. In addition, the period of 1995-2001 required a change in model-layer 1 specific yield values to better match measured data during the waterlevel rise associated with the artificial recharge program. For the 1956-94 simulation, the temporal discretization consisted of one-year stress periods for a total of 39 stress periods using three-month time steps; therefore, including the predevelopment stress period, there were a total of 40 stress periods from predevelopment to 1994. For the 1995-2001 simulation, the temporal discretization consisted of one-month stress periods for a total of 84 stress periods using one-week time steps. 


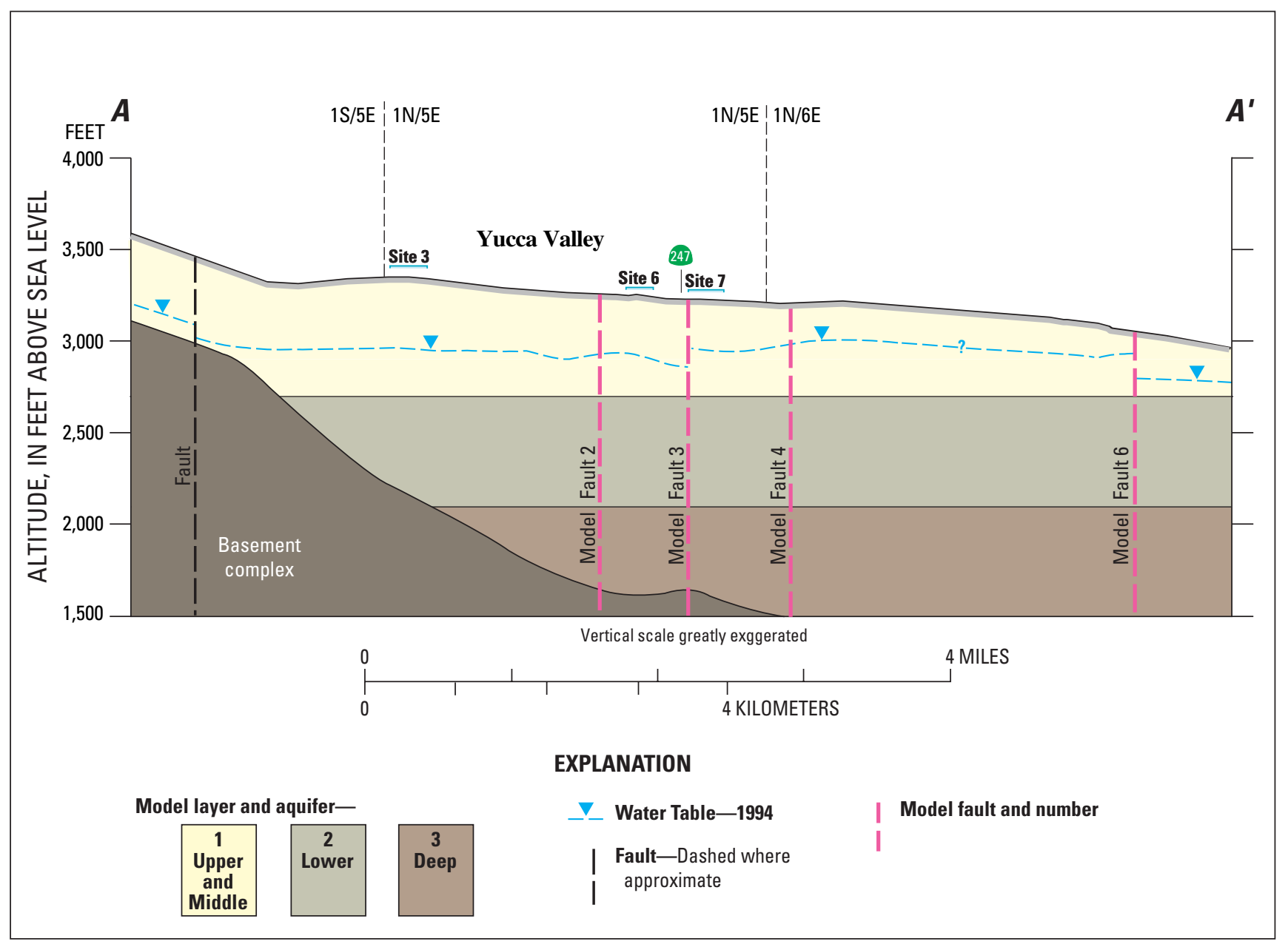

Figure 23. Vertical discretization along section line $A-A^{\prime}$ (see fig. 1) of the ground-water flow and solute-transport model of the Warren ground-water basin, San Bernardino County, California. 


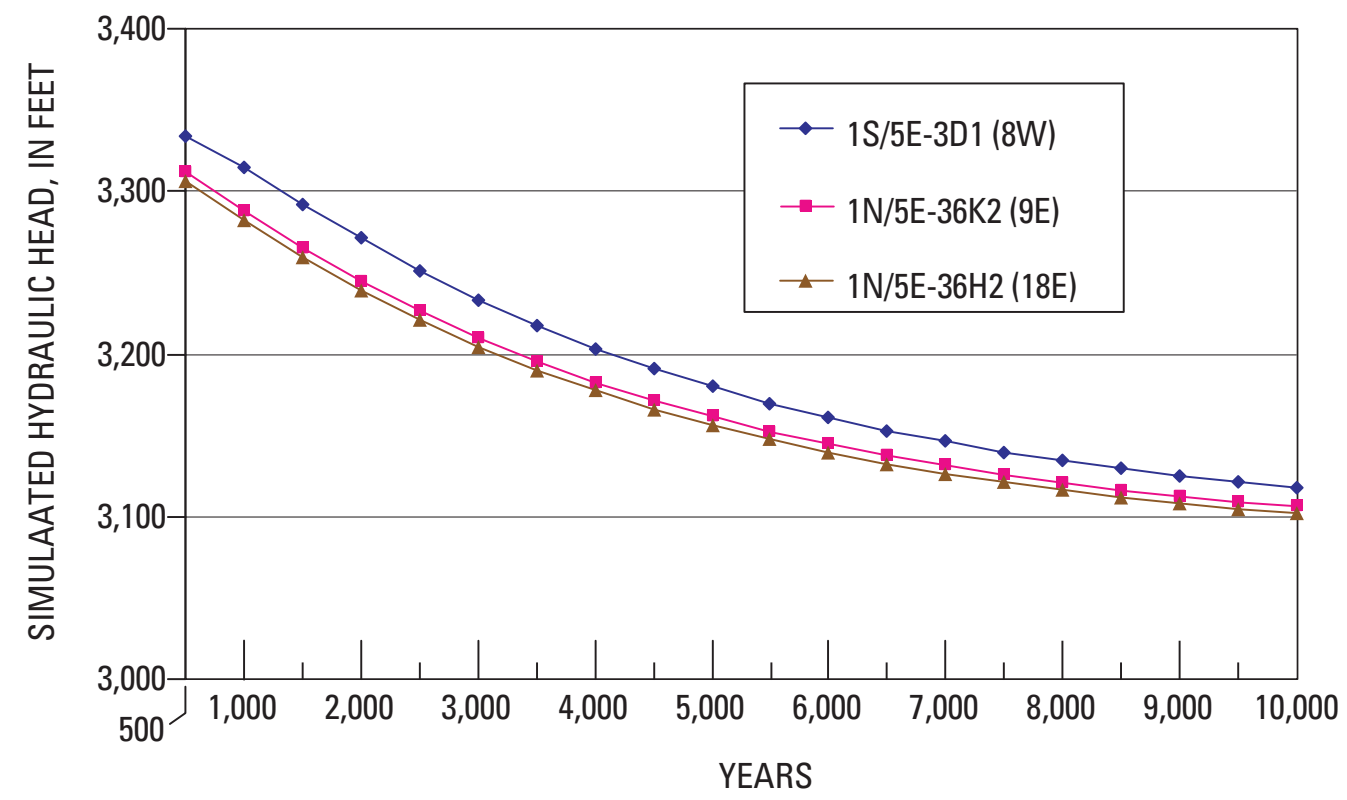

Figure 24. Simulated hydraulic head using no stresses for wells 1S/5E-3D1 (8W), 1N/5E-36K1 (HDWD-1), and 1N/5E-36H2 (18E) for 10,000 years, Warren ground-water basin, San Bernardino County, California. 
In order to determine the adequacy of the transient temporal discretization for both simulations, the time-varying mass-balance errors and the final mass-balance errors were considered. In general, the time-varying mass-balance errors should not fluctuate in an unstable manner, the solute-transport errors should be within \pm 10 percent (Konikow and others, 1996), and the final mass-balance errors should be relatively small. Figure 25 shows the percent massbalance error versus stress period for the ground-water flow and the solute-transport models. The groundwater flow error did not fluctuate and was about -0.06 percent over the last 82 stress periods (fig. 25). The solute-transport error from stress period 1 to 40 (predevelopment to 1994) decreased from about -0.7 percent to -0.5 percent and from stress period 41 to 124 (1995-2001) increased from -0.003 percent to -2.0 percent using a source concentration of either 220 $\mathrm{mg} / \mathrm{L}$ or $350 \mathrm{mg} / \mathrm{L}$. This increasing error may be due to the solute-transport modeling technique, resulting in a small mass tracking error (perhaps near a boundary); however, the errors were small enough for the model results to be credible (George Z. Hornberger, U.S. Geological Survey, written commun., 2002). The timevarying and final mass-balance errors indicate that the temporal discretizations were adequate.

\section{Model Boundaries}

For the ground-water flow model, three types of boundary conditions were used-no flow, general head, and specified flux. All lateral model boundaries, with the exception of the eastern boundary, were simulated as no-flow boundaries (fig. 22). For the most part, these boundaries correspond to faults and locations where gravity data indicate bedrock is at, or near, the watertable altitude. The bottom of the model corresponds with the top of the bedrock as defined by the gravity data. A general-head boundary was located at the eastern end of the model corresponding to the approximate location of the Yucca Barrier (figs. 1,22). Specified-flux boundary conditions were used to simulate natural and artificial recharge (septage, irrigation return flow, HDWD artificial recharge operations, and septage entrained by rising water levels).

For the solute-transport model, concentrations are associated with flow boundaries. Concentration values were specified at the general-head and specifiedflux boundaries for any inflowing water.

\section{Subsurface Properties}

\section{Ground-Water Flow Properties}

Model-layer properties [horizontal hydraulic conductivity, vertical conductance, storage coefficient, specific yield, hydraulic characteristic (used to simulate faults), and boundary conditions] affect the rate at which simulated water moves through an aquifer, the volume of water in storage, and the rate and areal extent of changes in ground-water levels caused by ground-water pumping and (or) recharge. For this study, some of the aquifer-system properties (horizontal hydraulic conductivity, vertical conductance, storage coefficient, and specific yield) were estimated initially from well logs, specificcapacity tests, and published literature. Final estimates of these properties were made using a trial-and-error approach under predevelopment and transient-state conditions (table 7).

Most aquifer-system properties (such as horizontal hydraulic conductivity and storage coefficient) are continuous functions of the spatial variables; therefore, the number of property values could be infinite. For estimation purposes, the infinite number of property values may be reduced through parameterization (Yeh, 1986). For this study, the hydraulic conductivity distribution for each model layer was assumed to be homogeneous and vertically anisotropic. However, it was found that the storage coefficient distribution was heterogeneous for modellayer 1, homogeneous for model-layers 2 and 3, and vertically anisotropic across all model layers. 


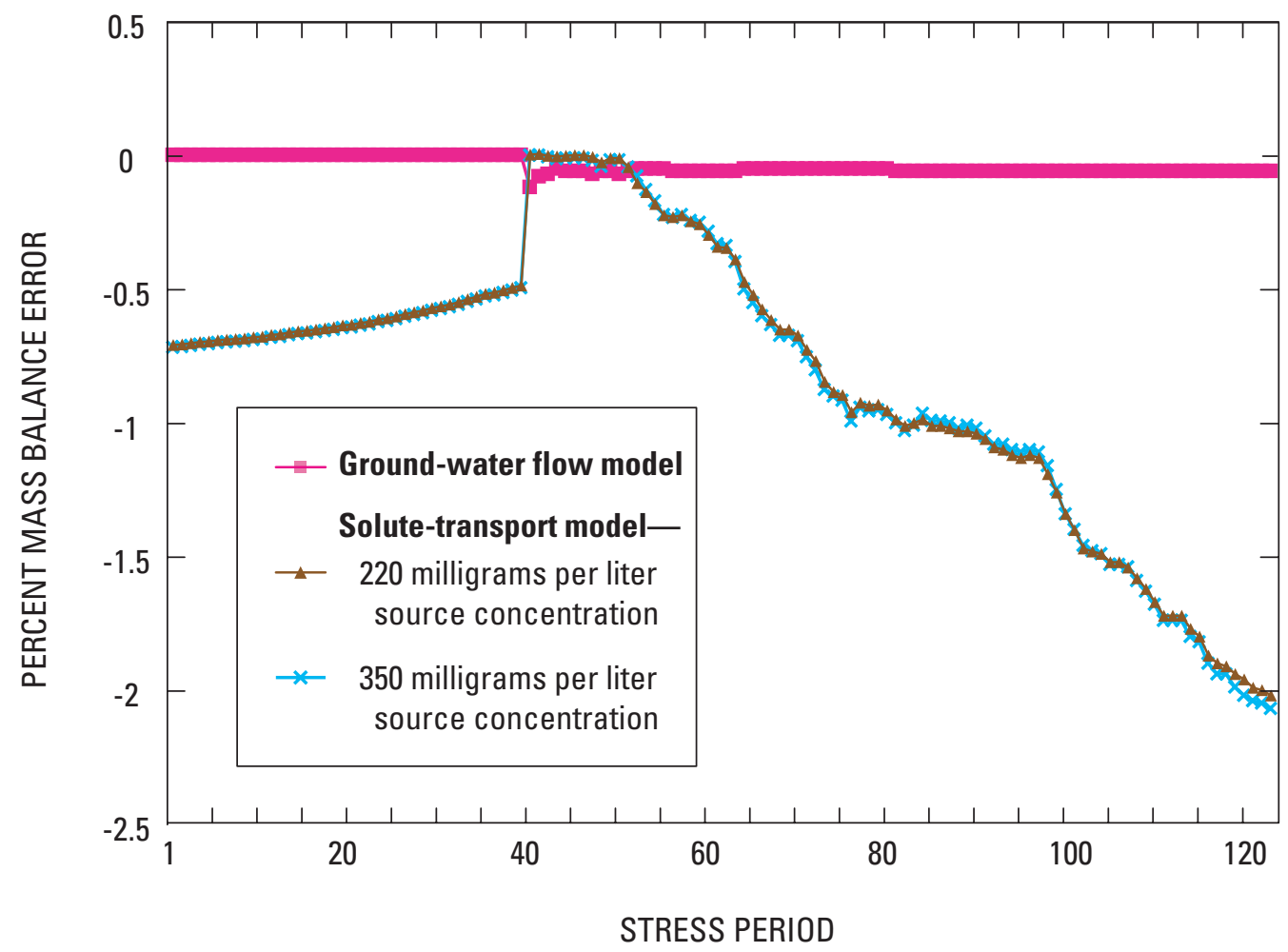

Figure 25. Time-varying mass-balance errors by stress period for the ground-water flow and solute-transport models, Warren ground-water basin, San Bernardino County, California. 
Table 7. Initial and final ground-water flow parameter estimates

[W, west hydrogeologic unit; MW, midwest hydrogeologic unit; E, mideast, northeast, and east hydrogeologic units; K, hydraulic conductivity in foot per day; $\mathrm{ft}$, foot; $\mathrm{K}_{\mathrm{z}}$, vertical hydraulic conductivity in foot per day; $\mathrm{S}_{\mathrm{y}}$, specific yield in foot per foot; $\mathrm{S}_{\mathrm{s}}$, specific storage in per foot; GHB, general-head conductance, in square foot per day; n/a, not applicable]

\begin{tabular}{|c|c|c|c|}
\hline Parameter & $\begin{array}{c}\text { Layer } 1 \\
\text { (initial) final }\end{array}$ & $\begin{array}{c}\text { Layer } 2 \\
\text { (initial) final }\end{array}$ & $\begin{array}{c}\text { Layer } 3 \\
\text { (initial) final }\end{array}$ \\
\hline $\bar{K}$ & (30.0) 30.0 & (5.0) 5.0 & $(0.5) 0.5$ \\
\hline $\mathrm{K}_{\mathrm{z}}$ & (.3) .3 & (.05) .05 & (.005).005 \\
\hline $\mathrm{S}_{\mathrm{y}}(\mathrm{W})$ pre-1995 & (.1) .28 & $(.1) .1$ & $\mathrm{n} / \mathrm{a}$ \\
\hline $\mathrm{S}_{\mathrm{y}}(\mathrm{MW})$ pre-1995 & (.1) .13 & (.1) .1 & $\mathrm{n} / \mathrm{a}$ \\
\hline $\mathrm{S}_{\mathrm{y}}(\mathrm{E})$ pre-1995 & (.1) .13 & (.1) .1 & $\mathrm{n} / \mathrm{a}$ \\
\hline $\mathrm{S}_{\mathrm{y}}(\mathrm{W})$ post-1995 & $(.28) .28$ & $(.1) .1$ & $\mathrm{n} / \mathrm{a}$ \\
\hline $\mathrm{S}_{\mathrm{y}}(\mathrm{MW})$ post-1995 & $(.14) .3$ & (.1) .1 & $\mathrm{n} / \mathrm{a}$ \\
\hline $\mathrm{S}_{\mathrm{y}}(\mathrm{E})$ post-1995 & (.13) .3 & (.1) .1 & $\mathrm{n} / \mathrm{a}$ \\
\hline $\mathrm{S}_{\mathrm{s}}$ & $\mathrm{n} / \mathrm{a}$ & $\left(5.0 \times 10^{-6}\right) 5.0 \times 10^{-6}$ & $\left(1.0 \times 10^{-6}\right) 1.0 \times 10^{-6}$ \\
\hline Fault 1 hydraulic characteristic ${ }^{1}$ & $\left(1.0 \times 10^{5}\right) 3.0 \times 10^{-6}$ & $\left(1.0 \times 10^{5}\right) 3.0 \times 10^{-6}$ & $\left(1.0 \times 10^{5}\right) 3.0 \times 10^{-6}$ \\
\hline Fault 2 hydraulic characteristic & $\left(1.0 \times 10^{5}\right) 2.0 \times 10^{-5}$ & $\left(1.0 \times 10^{5}\right) 2.0 \times 10^{-5}$ & $\left(1.0 \times 10^{5}\right) 2.0 \times 10^{-5}$ \\
\hline Fault 3 hydraulic characteristic & $\left(1.0 \times 10^{5}\right) 2.0 \times 10^{-4}$ & $\left(1.0 \times 10^{5}\right) 2.0 \times 10^{-4}$ & $\left(1.0 \times 10^{5}\right) 2.0 \times 10^{-4}$ \\
\hline Fault 4 hydraulic characteristic & $\left(1.0 \times 10^{5}\right) 5.0 \times 10^{-6}$ & $\left(1.0 \times 10^{5}\right) 5.0 \times 10^{-6}$ & $\left(1.0 \times 10^{5}\right) 5.0 \times 10^{-6}$ \\
\hline Fault 5 hydraulic characteristic & $\left(1.0 \times 10^{5}\right) 1.4 \times 10^{-6}$ & $\left(1.0 \times 10^{5}\right) 1.4 \times 10^{-6}$ & $\left(1.0 \times 10^{5}\right) 1.4 \times 10^{-6}$ \\
\hline Fault 6 hydraulic characteristic & $\left(1.0 \times 10^{5}\right) 2.0 \times 10^{-5}$ & $\left(1.0 \times 10^{5}\right) 2.0 \times 10^{-5}$ & $\left(1.0 \times 10^{5}\right) 2.0 \times 10^{-5}$ \\
\hline Fault 7 hydraulic characteristic & $\left(1.0 \times 10^{5}\right) 1.0 \times 10^{-5}$ & $\left(1.0 \times 10^{5}\right) 1.0 \times 10^{-5}$ & $\left(1.0 \times 10^{5}\right) 1.0 \times 10^{-5}$ \\
\hline GHB & $\left(1.0 \times 10^{2}\right) 1.8 \times 10^{-3}$ & $\left(1.0 \times 10^{2}\right) 1.8 \times 10^{-3}$ & $\left(1.0 \times 10^{2}\right) 1.8 \times 10^{-3}$ \\
\hline GHB head (ft) & $\left(2.5 \times 10^{3}\right) 2.5 \times 10^{-3}$ & $\left(2.5 \times 10^{3}\right) 2.5 \times 10^{3}$ & $\left(2.5 \times 10^{3}\right) 2.5 \times 10^{3}$ \\
\hline
\end{tabular}

\footnotetext{
' per day for layer 1 and foot per day for layers 2 and 3.
} 


\section{Hydraulic Conductivity and Transmissivity}

A medium has a hydraulic conductivity $(K)$ of unit length per unit time if it will transmit in unit time a unit volume of ground water at the prevailing viscosity through a cross section of unit area, measured at right angles to the direction of flow, under a hydraulic gradient of unit change in head through unit length of flow (Lohman, 1979). The transmissivity ( $T$ or $K b$, where $b=$ aquifer thickness) is the rate at which water of the prevailing kinematic viscosity is transmitted through a unit width of the aquifer under a unit hydraulic gradient (Lohman, 1979). Hydraulic conductivity is used for model layers 1 and 2 because model layer 1 represents an unconfined aquifer and model layer 2 may be confined or unconfined.

Transmissivity is used for model layer 3 because this layer represents a confined aquifer. Initial estimates of $K$ and $T$ values were derived from aquifer tests, specific-capacity tests, and drillers' logs from previous studies.

\section{Storage Coefficient and Specific Yield}

The storage coefficient ( $S$, also known as storativity) of a saturated confined aquifer of thickness $b$ is the volume of water that an aquifer releases from storage per unit of surface area of aquifer per unit decline in the component of hydraulic head normal to that surface (Freeze and Cherry, 1979). For confined aquifers, water is released from storage when pumping causes a decrease in pore-fluid pressure (hydraulic head or head is equal to the pore-fluid pressure divided by the specific weight of water) that increases the intergranular stress transmitted by the solid skeleton of the aquifer and results in a small reduction in porosity. The decrease in pore-fluid pressure produces a slight expansion of water. The combination of the small reduction in porosity and the slight expansion of the water results in a certain volume of water being released from storage (Bear, 1979). The specific yield $\left(S_{y}\right)$ for an unconfined aquifer is the volume of water released from storage per unit surface area of aquifer per unit decline in the water-table (Freeze and Cherry, 1979). For unconfined aquifers, water is released from storage when a decline in ground-water levels results in the desaturation of the porous medium. $S_{y}$ was specified for model-layer 1 and $S$ [specifically, specific storage $\left.\left(S_{S}=S / b\right)\right]$ was specified for model-layers 2 and 3.

\section{Vertical Conductance}

A vertical transmission or leakage term, known in the MODFLOW model as VCONT, controls the flow between model layers (McDonald and Harbaugh, 1988). The vertical $K$ values are based on the initial horizontal $K$ value for each layer using an assumed 100:1 vertical anisotropy ratio. VCONT is calculated using the following equation:

$$
\text { VCONT }=\frac{2}{\left(\frac{B_{i}}{K_{i} \cdot A_{i}}\right)+\left(\frac{B_{i+1}}{K_{i+1} \cdot A_{i+1}}\right)}
$$

where:

VCONT is the leakage between model layers $i$ and $i+1\left(t^{-1}\right)$,

$B \quad$ is the thickness of a model layer $(L)$,

$K \quad$ is the hydraulic conductivity of a model layer $\left(L t^{-1}\right)$, and

A is the anisotropy ratio of a model layer (1)

The horizontal $K$ value for model layer 3 was calculated by dividing the initial $T$ value by the model layer thickness. Note that for this study, implicit to estimating VCONT, one is actually estimating the anisotropy. 


\section{Faults}

Faults may be barriers to ground-water flow. The faults in the Warren ground-water basin were modeled using the Horizontal-Flow-Barrier (HFB) Package (Hsieh and Freckleton, 1993). The HFB package simulates faults as thin, vertical, low-permeability geologic features that impede the horizontal flow of ground water. Faults are approximated as a series of horizontal-flow barriers conceptually situated between pairs of adjacent cells in the finite-difference grid (Hsieh and Freckleton, 1993). Flow across a simulated fault is proportional to the hydraulic-head difference between adjacent cells. The constant of proportionality is the hydraulic characteristic ( $L t^{-1}$ for confined and $t^{-1}$ for unconfined), the value was determined during the calibration process.

Hornberger and others (2002) reported that applying the HFB Package in a solute-transport model can lead to errors caused by the assumption of zero storage within the flow barrier and negligible barrier width. These errors are in the form of overestimated concentrations yielding conservative estimates of solute transport.

Seven faults were simulated as internal barriers to ground-water flow and solute transport; the fault locations are shown in figure 22. The distribution of faults resulted in subareas within the subbasin that correspond to the hydrogeologic units (fig. 1). All of the model faults follow previously mapped and inferred faults with the exception of fault F5. The trace of fault F5, which separates the northeast and east hydrogeologic units, was changed because the measured water levels at well $1 \mathrm{~N} / 6 \mathrm{E}-31 \mathrm{C} 1(5 \mathrm{E})$ were more similar to those in the northeast hydrogeologic unit than those in the east hydrogeologic unit.

Initially, the hydraulic characteristic value for each fault was set to a large value allowing ground water to flow freely across the faults. Through the calibration process, the hydraulic characteristic values were lowered such that the simulated hydraulic heads and $\mathrm{NO}_{3}$ concentrations closely matched measured values.

\section{Solute-Transport Properties}

Some model properties that affect solute transport are retardation factor, first-order decay term, and hydrodynamic dispersion. The solute of interest for this study is $\mathrm{NO}_{3}$ which will not sorb to the solid phase of the porous medium; therefore, it is assumed that the retardation factor equaled one [see Konikow and others (1996) for further explanation of the retardation factor]. It is further assumed that the $\mathrm{NO}_{3}$ does not decay as most of the $\mathrm{NO}_{3}$ is found in the upper, unconfined aquifer; therefore, denitrification probably will not occur in this aerobic environment.

Hydrodynamic dispersion describes the spreading of a solute resulting from mechanical dispersion and molecular diffusion (Bear, 1979). Mechanical dispersion is caused by velocity variations at the microscopic scale and molecular diffusion is caused by the solute concentration gradient (Bear, 1979). For the purposes of this study, it is assumed that molecular diffusion is much smaller than mechanical dispersion and is, therefore, assumed to equal zero. Hydrodynamic dispersion, assuming zero molecular diffusion, is a function of dispersivity $(L)$ and average velocity (Bear, 1979; Konikow and others, 1996). Note that dispersivity is a fourth rank tensor and, in three dimensions, has 36 nonzero components (Bear and Verruijt, 1987). Assuming an isotropic aquifer, the number of dispersivity components reduces to two: that is, longitudinal dispersivity $\left(\alpha_{\mathrm{L}}\right)$ which explains the spreading of the solute along the flowpath; and transverse dispersivity $\left(\alpha_{\mathrm{T}}\right)$, which explains the spreading of the solute transverse to the flowpath (Scheidegger, 1961). Konikow and others (1996) follow the work of Burnett and Frind (1987) and further divide the transverse dispersivity into two components; that is, horizontal transverse dispersivity $\left(\alpha_{\mathrm{TH}}\right)$ and vertical transverse dispersivity $\left(\alpha_{\mathrm{TV}}\right)$. 
It is rare that the components of dispersivity are estimated using field data; however, Gelhar and others (1992) compiled and reported dispersivity estimates measured at various longitudinal scales. The longitudinal scale of this problem is about $33,000 \mathrm{ft}$. Gelhar and others (1992) reported $\alpha_{L}$ values between $17 \mathrm{ft}$ and $20,000 \mathrm{ft}$ for longitudinal scales of between 3,300 and 330,000 ft. For this work, an $\alpha_{\mathrm{L}}$ of $750 \mathrm{ft}$ was assumed. Gelhar and others (1992) also reported the ratio of longitudinal to horizontal and vertical transverse dispersivities. For the longitudinal scale between 3,300 and $330,000 \mathrm{ft}$, the longitudinal to horizontal ratio was between 10/1 and 3/1 [Gelhar and others (1992) reported that $3 / 1$ is commonly used in numerical simulations] and the longitudinal to vertical ratio was about 300/1. The longitudinal-to-horizontal ratio yielded horizontal transverse dispersivity values between $75 \mathrm{ft}$ and $250 \mathrm{ft}$, where $250 \mathrm{ft}$ (a ratio of 3/1) was used for this work. The longitudinal-to-vertical ratio yielded a vertical transverse dispersivity value of $2.5 \mathrm{ft}$.

\section{Model Recharge}

Model recharge included natural and artificial recharge (septage, irrigation return flow, HDWD artificial recharge operations, and septage entrained by rising water levels). Specified flux boundary condition was used to simulate the natural recharge and artificial recharge.

\section{Natural Recharge}

Natural ground-water recharge in the Warren ground-water basin occurs primarily as mountain-front recharge (infiltration of runoff from washes along the San Bernardino Mountains). Recharge from precipitation was not included in the model because of the low precipitation rate (6.75 in./yr) and high evaporation rate (66 in./yr). Streamflow recharge was not included because no perennial streams flow in the basin (Lewis, 1972) and it was assumed that the rare stormflow events are insignificant sources of recharge. The $\mathrm{NO}_{3}$ concentration of the natural recharge was assumed to equal the background concentration of $10 \mathrm{mg} / \mathrm{L}$.

The total natural recharge rate of about 83 acre$\mathrm{ft} / \mathrm{yr}$ was estimated by calibrating model simulations to match observed heads; this is lower than the 200 acre- $\mathrm{ft} / \mathrm{yr}$ estimated by Lewis (1972). The natural recharge was simulated along the model boundary at four areas (fig. 22). The western-most area corresponds to Water Canyon and had a natural recharge rate of about 8 acre$\mathrm{ft} / \mathrm{yr}$. For calibration purposes, the central natural recharge area was divided into two parts (fig. 22); the west-central part corresponding to the midwest hydrogeologic unit had a recharge rate of about 17 acre-ft/yr and the east-central part corresponding to the mideast hydrogeologic unit had a recharge rate of about 24 acre-ft/yr. The eastern-most natural recharge area corresponding to the northeast hydrogeologic unit had a recharge rate of about 34 acre-ft/yr.

\section{Artificial Recharge}

The models include four sources of artificial recharge; septage, irrigation return flow, the HDWD artificial recharge program, and the entrainment of water in the unsaturated zone by the water-level rise resulting from the HDWD artificial recharge program. The potential septage and irrigation return flow values were estimated using land-use maps based on aerial photographs of the Warren subbasin. Photographs of the basin were available for 1952-53, 1965, 1977, and 1993. These photographs were analyzed using a geographic information system (GIS) for land use, in which land use was categorized as commercial, residential (single-family residences), multi-family residences, and irrigated recreational fields (for example, parks and golf courses) (fig. 2). The commercial, residential, and multi-family residence land uses were used to estimate septic recharge and the open fields land use was used to estimate irrigation return flow recharge. The potential quantity of septictank seepage and irrigation return flow recharge for each land-use map is shown in table 2. Each land-use map was overlain on the model grid and the area of each land-use category within a model cell was estimated. The septage and irrigation return flow recharge values for each land-use map were estimated by multiplying the area of each land-use category within a model cell by its respective septic discharge or irrigation return rate. Figure 26 shows the areal distribution of irrigation return flow and septage for the 1956-64, 1965-76, 1977-89, 1990-94, and 1995-2001 simulations. 


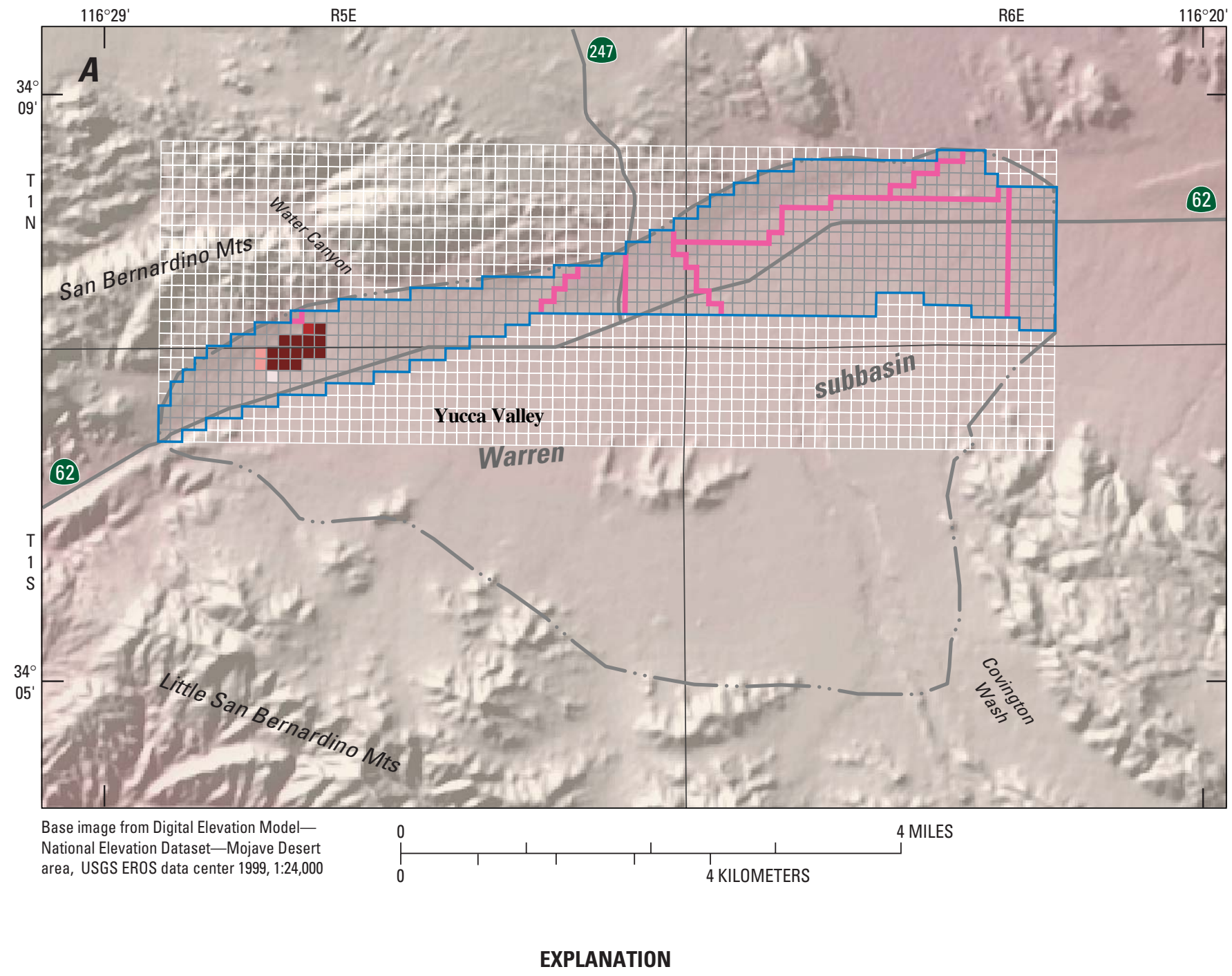

Active cells

Inactive cells

Model fault locations

Warren ground-water basin model boundary

Figure 26. Areal distribution of irrigation return flow and septage for: $(A)$ 1956-64, (B) 1965-76, (C) 1977-1989, (D) 1990-94, and (E) 1995-2001, Warren ground-water basin, San Bernardino County, California. 


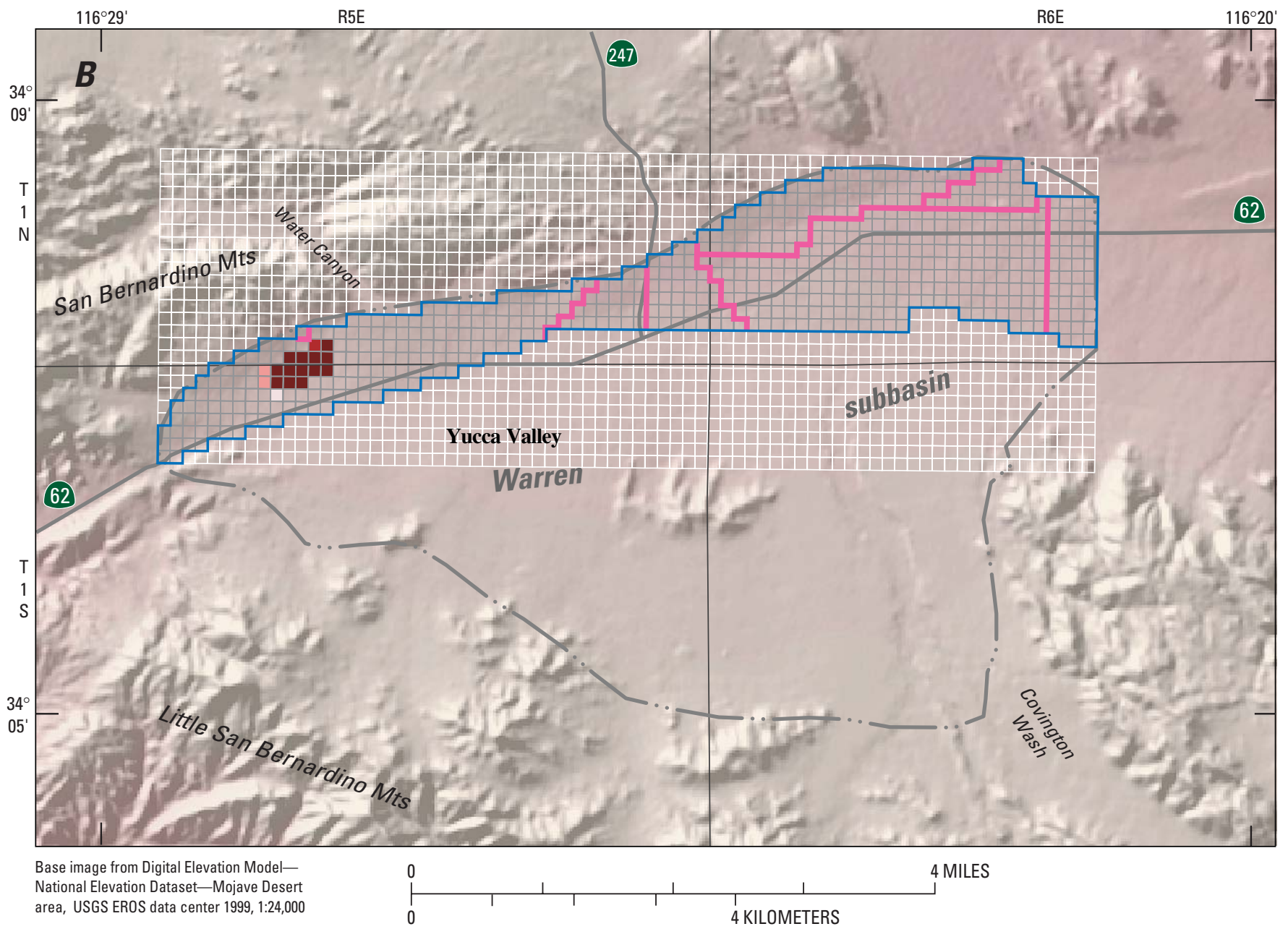

\section{EXPLANATION}

Artificial recharge: Irrigation return flow and septage 1965-76

- In acre-feet per year

$\square 0.2-0.25$

$\square 0.25-0.3$

$\square 0.3-0.35$

$\square$ 0.35-0.4

- $0.4-0.45$

\section{Active cells}

Inactive cells

Model fault location

Warren ground-water basin model boundary

Figure 26.-Continued. 


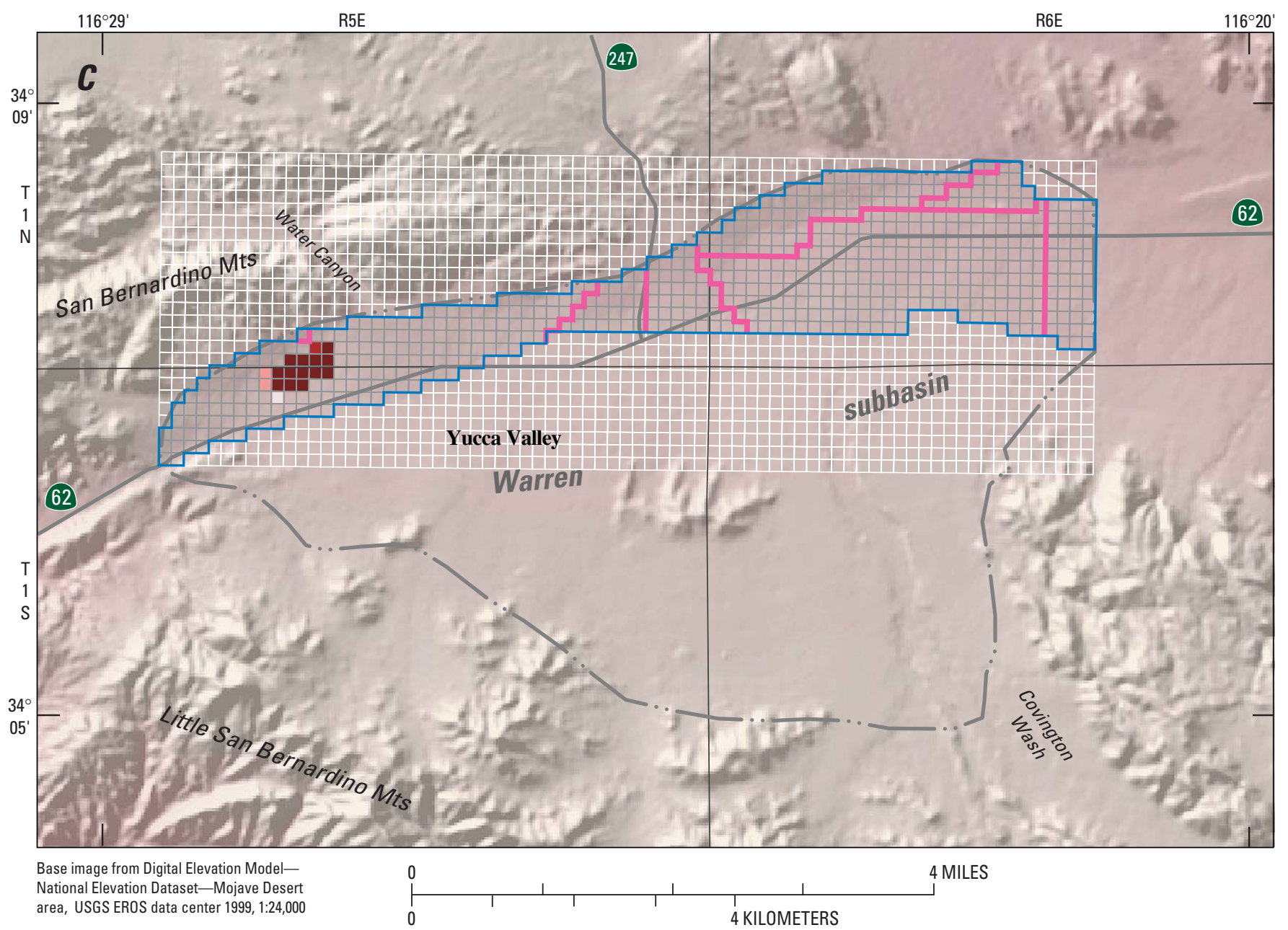

EXPLANATION

Artificial recharge: Irrigation return flow and septage 1977-89

-In acre-feet per year

$\square 0.2-0.25$

$\square 0.25-0.3$

$\square 0.3-0.35$

- $0.35-0.4$

— $0.4-0.45$

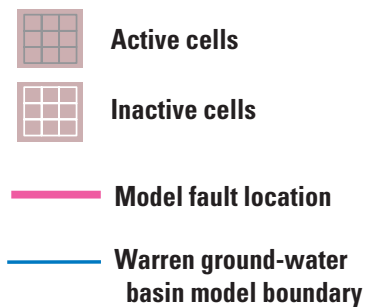

Figure 26.-Continued. 


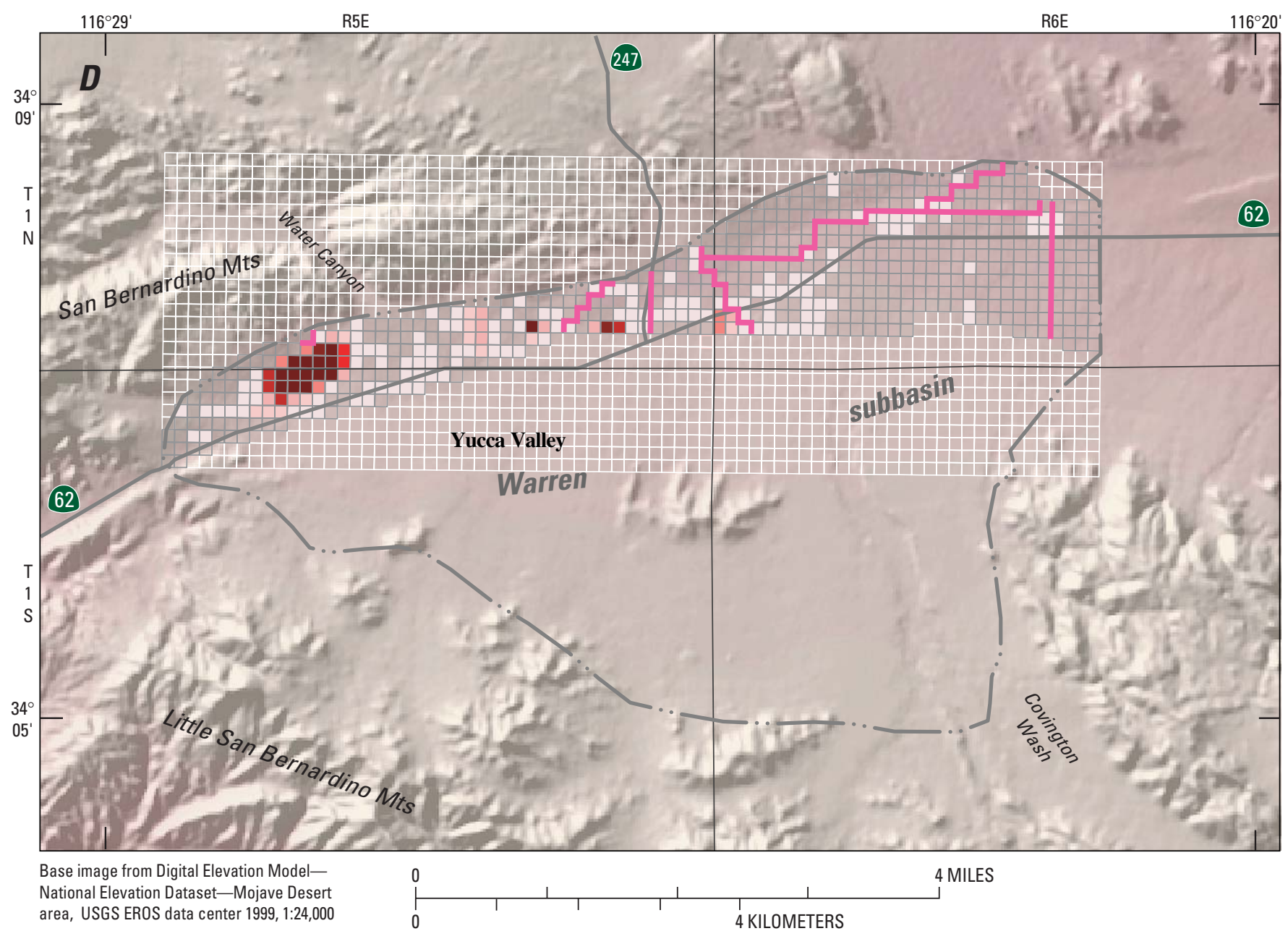

\section{EXPLANATION}

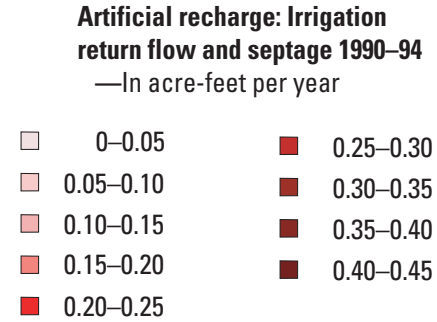

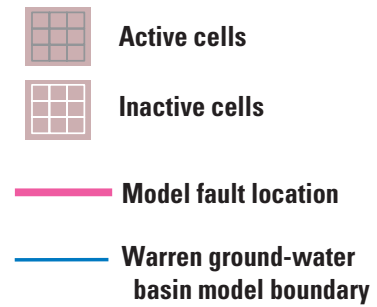

Figure 26.-Continued. 


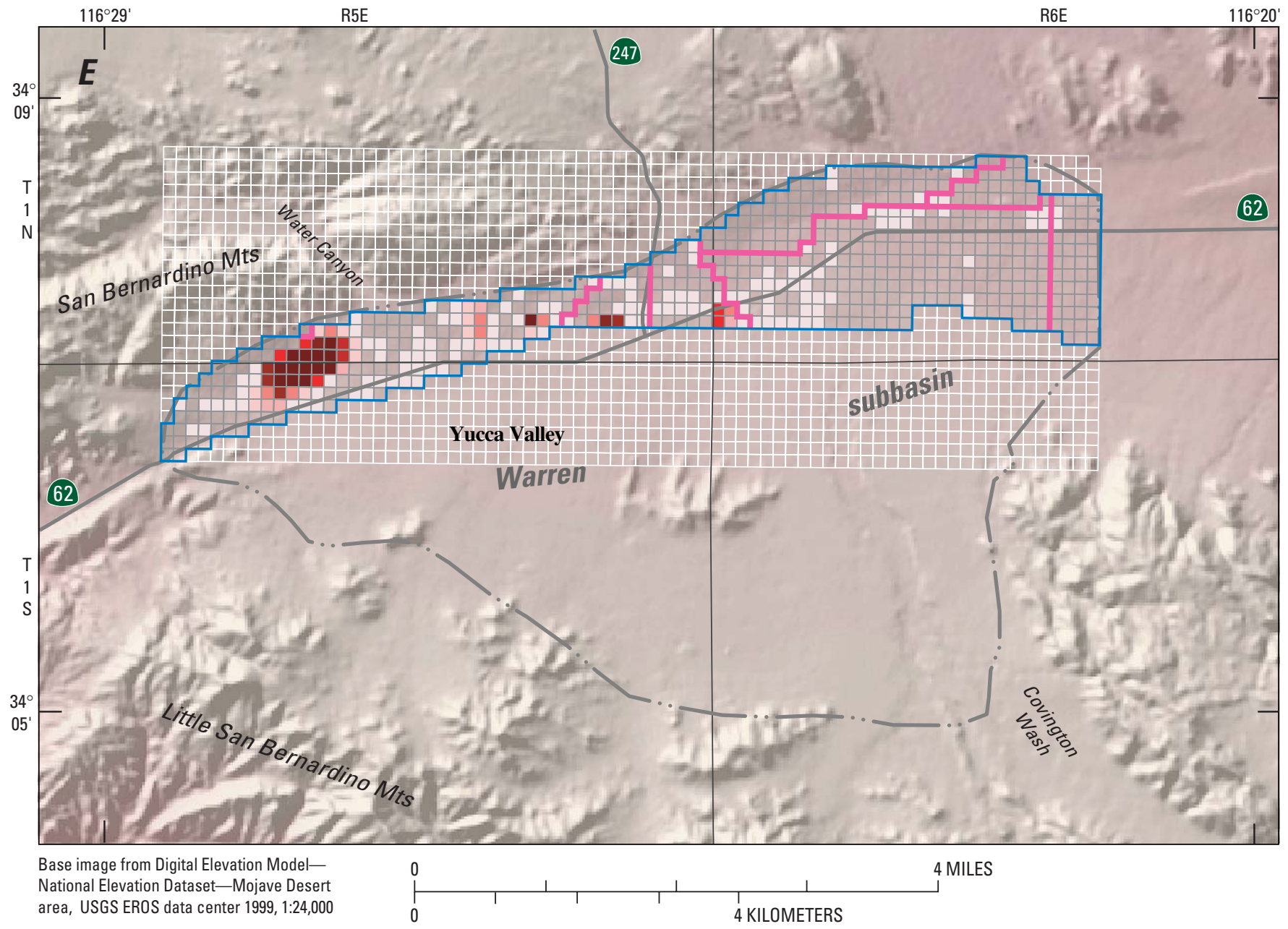

\section{EXPLANATION}

\begin{tabular}{|c|c|c|}
\hline \multicolumn{3}{|c|}{$\begin{array}{l}\text { Artificial recharge: Irrigation } \\
\text { return flow and septage 1995-2001 } \\
\text {-In acre-feet per year }\end{array}$} \\
\hline 2.15 & $\square$ & $19.13-21.46$ \\
\hline $2.15-6.44$ & $\square$ & $21.46-30.04$ \\
\hline $6.44-10.73$ & $\square$ & $30.04-36.47$ \\
\hline 10.73-15.02 & & $36.47-42.91$ \\
\hline
\end{tabular}

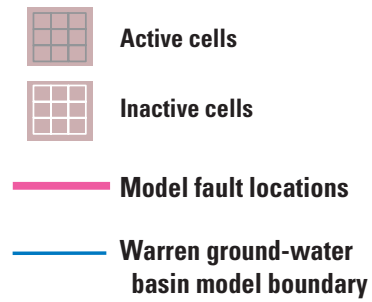

Figure 26.-Continued. 
Associated with each land-use category was a $\mathrm{NO}_{3}$ concentration. The $\mathrm{NO}_{3}$ concentration associated with commercial, residential, and multi-family dwellings was simulated using concentrations of 220 and $350 \mathrm{mg} / \mathrm{L}$, thus requiring two separate simulations. The $\mathrm{NO}_{3}$ concentration associated with irrigated recreational fields was simulated using $88 \mathrm{mg} / \mathrm{L}$.

The $\mathrm{NO}_{3}$ concentration of the recharge water for each model cell was a weighted function of the recharge rates and $\mathrm{NO}_{3}$ concentrations for each land use within the model cell, that is,

$$
C_{\text {tot }}=\sum_{i=1}^{n} \frac{Q_{i}}{Q_{t o t}} \times C_{i},
$$

where $C_{t o t}$ is the total $\mathrm{NO}_{3}$ concentration $\left(M L^{-3}\right)$ for the model cell, $n$ is the number of land uses, $Q_{i}$ is the recharge rate for land use $i\left(L^{3} t^{-1}\right), C_{i}$ is the $\mathrm{NO}_{3}$ concentration for land use $i$, and $Q_{t o t}$ is the total recharge rate in the model cell. The use of flowrates in equation 5 is valid because the time steps used to calculate $Q_{t o t}$ and $Q_{i}$ are equal.

The HDWD recharge operation started in February 1995 at recharge sites 6 and 7 (fig. 1). This recharge was simulated at single cells located at the top of model layer 1 and the rates were simulated using time-varying, specified fluxes. HDWD only recorded the total monthly volume of water recharged in the Warren ground-water basin from 1995 to 2001; therefore, it was assumed that each site received half of the water (see figure 8 for the total monthly volumes). Water-quality samples of the recharge water supplied by MWA had $\mathrm{NO}_{3}$ concentrations ranging from less than 1 to about $4 \mathrm{mg} / \mathrm{L}$ (Norman Caouette, Mojave Water Agency, written commun., 2002); therefore, the concentration of the recharge water was simulated using $2 \mathrm{mg} / \mathrm{L}$.

The HDWD recharge operation resulted in ground-water levels recovering almost $250 \mathrm{ft}$ and the rising ground water entrained septage in the unsaturated zone. It was assumed that the septage was entrained during the three year period of 1995-97. In order to estimate the volume of entrained unsaturated zone water, a map of water-level change was constructed (fig. 27) using two water-level maps: a map showing 1994 conditions (Trayler and Koczot, 1995) and a map showing 1998 conditions (Smith and Pimentel, 2000). The volume of recharge from the entrainment of the unsaturated-zone water by the rising ground water was estimated for each model cell by multiplying the change in water levels between 1994 and 1998 within each model cell by the cell area and by the moisture content related to the land-use category [0.15 for developed areas (commercial, residential, multi-family, and irrigated recreational fields) and 0.02 for undeveloped areas (desert)]. The recharge rate of the entrained unsaturated-zone water was then calculated by dividing the recharge volume by the number of days of water-level rise ( 3 years $=1,095$ days) (fig. 28).

The $\mathrm{NO}_{3}$ concentration of the entrained water associated with the water-level rise was calculated using equation 5. The $\mathrm{NO}_{3}$ concentrations were 220 and $350 \mathrm{mg} / \mathrm{L}$ for commercial, residential, multifamily land uses; $88 \mathrm{mg} / \mathrm{L}$ for open fields; and $10 \mathrm{mg} / \mathrm{L}$ for undeveloped areas.

\section{Model Discharge}

Ground-water discharge in the Warren groundwater basin occurs primarily as pumpage and groundwater underflow along the eastern edge of the basin. Evaporation from the recharge ponds was not addressed for two reasons: (1) the ponds were filled at night to minimize evaporation (Marty Stockstell, HDWD, written commun., 2002) and (2) the average monthly total evaporation rate from both ponds was much less [about 4.6 acre-ft/mo (assuming a total recharge area of 10 acres and an evaporation rate of 66 in./yr)] than the average total recharge rate of about $290 \mathrm{acre}-\mathrm{ft} / \mathrm{mo}$. Evapotranspiration was not simulated because the depth to ground water was such that this discharge did not occur.

\section{Pumpage}

Pumpage data on a per-well basis were not available for the period 1956-1990. Lewis (1972) reported total annual pumpage for public supply and the golf course for the period 1956-69. For this simulation period, public supply pumpage was evenly divided among production wells actively pumped in a given year and golf-course pumpage was evenly divided among active irrigation-supply wells in a given year. 


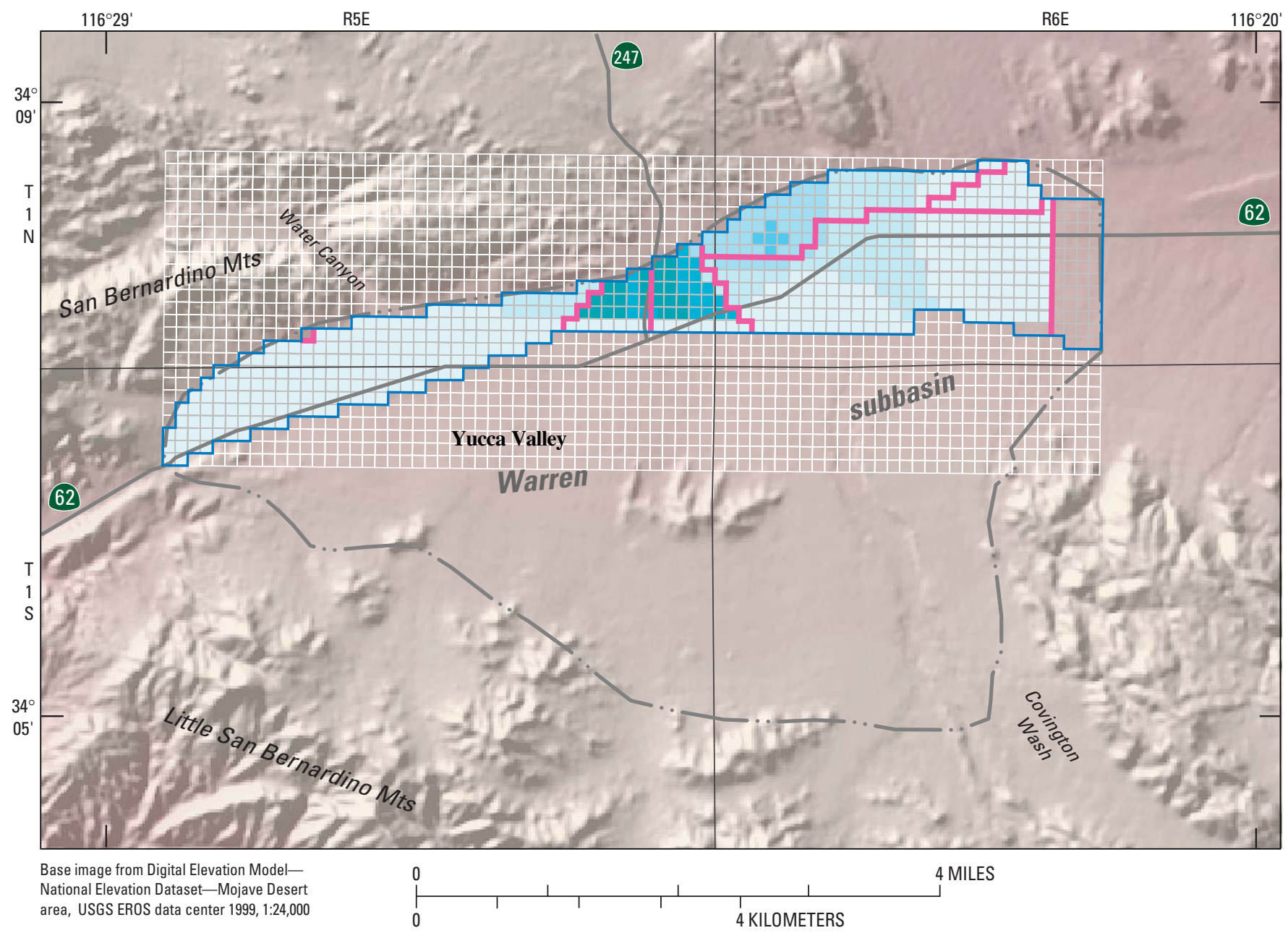

\section{EXPLANATION}

\begin{tabular}{c|c} 
Water level change 1994-98 \\
- In feet \\
$\square \quad 7-15$ & Active cells \\
$\square \quad 16-37$ & Inactive cells \\
$\square \quad 38-60$ & Model fault locations \\
$\square \quad 61-82$ & Warren ground-water \\
$\square \quad 83-105$ & basin model boundary \\
$\square \quad 106-127$ & \\
$\square \quad 128-150$ & \\
$\square \quad 151-172$ & \\
$\square \quad 173-195$ & \\
$\square \quad$ No data
\end{tabular}

Figure 27. Water-level change between 1994 and 1998, Warren ground-water basin, San Bernardino County, California. 


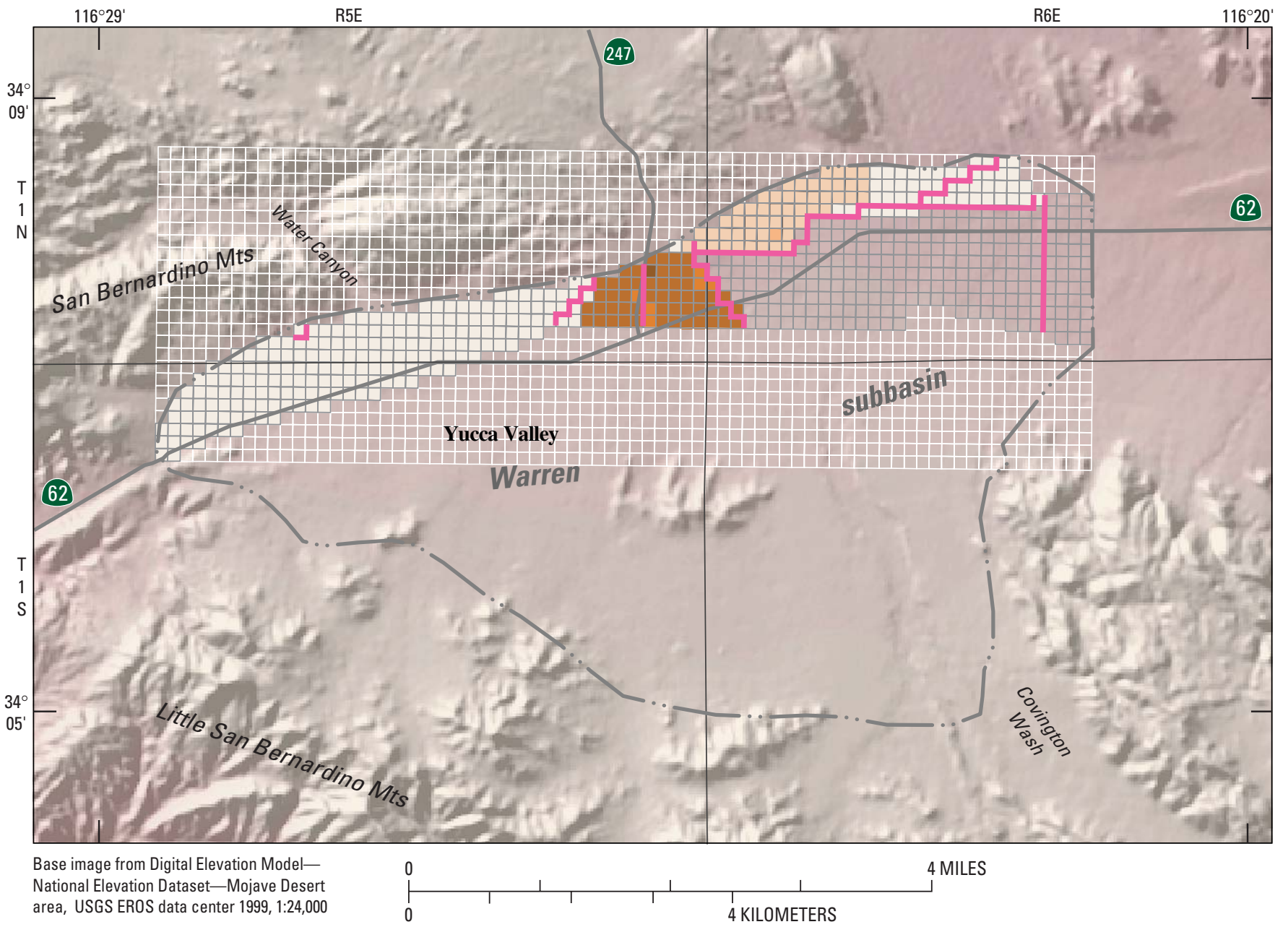

\section{EXPLANATION}

Recharge rate of entrained
unsaturated-zone septage
(1995-97)-In acre-feet per yea
$\square \quad 0-10 \quad \square \quad 40-50$
$\square \quad 10-20 \quad \square \quad 50-60$
$\square \quad 20-30$
$\square 30-40$

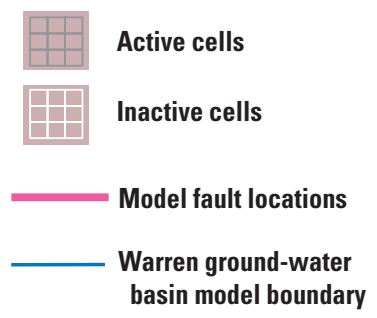

Figure 28. Areal distribution of entrained unsaturated-zone water for 1995-97, Warren ground-water basin, San Bernardino County, California. 
Pumpage data were not available for the period 1970-90. In order to estimate the pumpage between 1970-90, population data for the subbasin were used in combination with an assumed per capita water usage rate of $130 \mathrm{gal} / \mathrm{d}$. Population data were only available for 1967, 1985, and 1992; the missing population data were linearly interpolated. The resulting total water demand was evenly distributed among active wells in a given year. The golf course did not expand during this period; therefore, it was assumed that the pumpage rate used for the period 1956-69 is valid and was evenly distributed among the active irrigation-supply wells.

Total annual pumpage data were available on a per-well basis for the period 1991-94. Monthly pumpage data were available on a per-well basis for the period 1995-2001. The total annual pumpage data for production wells in the Warren ground-water basin are shown in figure 7.

Pumpage was distributed among the model layers on the basis of the relative percentage of that layer's hydraulic conductivity compared with the average hydraulic conductivity of the model layers in which the well is perforated; that is,

$$
Q_{i}=\frac{Q \bullet K_{i} \bullet b_{i} \bullet \delta_{i}}{\sum_{i=1}^{n}\left(K_{i} \bullet b_{i} \bullet \delta_{i}\right)}
$$

where:

$Q_{i} \quad$ is the pumping rate from model layer $i\left(L^{3} t^{-1}\right)$,

$Q \quad$ is the total pumping rate,

$K_{i} \quad$ is the hydraulic conductivity of model layer $i\left(L t^{-1}\right)$,

$b_{i} \quad$ is the thickness of model layer $i(L)$,

$\delta_{i} \quad$ is the Dirac delta function (= 1 if well is perforated in layer $i$ and $=0$ if well is not perforated in layer $i$ ), and

$n \quad$ is the number of model layers.

\section{Ground-Water Underflow}

Ground-water underflow occurs along the eastern edge of the basin exiting the Warren subbasin across the Yucca Barrier. This underflow was simulated using a general-head boundary (fig. 22). A generalhead boundary is used to simulate a source of water outside the model area that either supplies water to, or receives water from, the model at a rate proportional to the hydraulic-head differences between the source and the model. The constant of proportionality is termed the conductance $\left(L^{2} t^{-1}\right)$. The general-head boundary controls the rate at which water is exchanged between the model cell and the outside source.

Initially, the conductance value was set to a large value allowing ground water to flow freely across the boundary. Through the calibration process, the conductance value was lowered such that the simulated hydraulic heads and $\mathrm{NO}_{3}$ concentrations closely matched measured values.

\section{Model Calibration}

The ground-water flow and solute-transport models of the Warren ground-water basin were iteratively calibrated using a trial-and-error process in which the initial estimates of the aquifer properties were adjusted to improve the match between simulated hydraulic heads and $\mathrm{NO}_{3}$ concentrations with measured ground-water levels and $\mathrm{NO}_{3}$ concentrations. Measured ground-water levels and $\mathrm{NO}_{3}$ concentration for predevelopment and the period 1956-2001 were used to calibrate the ground-water flow and transport models. Predevelopment conditions were simulated in the first stress period of the transient simulations. The iterative calibration process involved calibrating the parameters to minimize hydrologic-budget error, match measured water levels, match measured $\mathrm{NO}_{3}$ concentrations, and simulate reasonable boundary fluxes. If a satisfactory match between measured and simulated results was not obtained, the process was restarted. 


\section{Ground-Water Flow Model}

Measured ground-water levels collected prior to 1959 were used to calibrate the ground-water flow model for predevelopment conditions because these data yielded the most complete dataset when pumpage was relatively low. Measured ground-water levels from 1959 to 2001 were used to calibrate the ground-water flow model for transient conditions caused by stresses within the basin. Changes in the hydrologic conditions from 1959 to 2001 are the result of stress on the aquifer system caused by ground-water pumping and recharge. Seasonal and long-term climate influence also can influence hydrologic conditions but they are not addressed in this study. The magnitude of variability in the simulated hydraulic heads is dependent on groundwater pumping, artificial recharge, natural recharge, boundary conditions, hydraulic parameters $(K, T$, $V C O N T, S_{y}$, and $S_{S}$ ), and fault parameters (hydraulic characteristic).

Measured annual pumpage data from 1956 to 1994 and monthly pumpage from 1995 to 2001 were entered into the model by layer on the basis of the $K$ value of the model layer (see eqn 6). Measured monthly artificial recharge data from 1995 to 2001 were entered into model layer 1 . The water-level rise resulting from the artificial recharge program entrained about 6,300 acre-ft/yr of unsaturated-zone water from 1995 to 1997 represents an additional source of recharge and was simulated using a specified-flux boundary condition (see the "Artificial Recharge" section).

The natural-recharge fluxes and general-head boundary parameter were estimated through calibration such that the simulated hydraulic heads approximated measured predevelopment water levels (pre-1959 ground-water levels). The natural recharge locations are shown in figure 22. The calibrated value for natural recharge was about 83 acre-ft/yr.

A general-head boundary was located at the eastern end of the model to simulate ground-water underflow across the Yucca Barrier (figs. 1,22). Water levels on the eastern side of the Yucca Barrier are about 2,500 ft above sea level and have changed little since 1958 (Lewis, 1972); therefore, the head of the generalhead boundaries for each model layer was set equal to $2,500 \mathrm{ft}$. The initial conductance value was $100 \mathrm{ft}^{2} / \mathrm{d}$, which allowed water to freely leave the basin. The final general-head-conductance value was $0.0018 \mathrm{ft}^{2} / \mathrm{d}$. This relatively low value is required to simulate the observed 400-ft water-level decline across the Yucca Barrier.

The initial estimates of hydraulic conductivity for model layers 1-3 were $30.0,5.0$, and $0.5 \mathrm{ft} / \mathrm{d}$, respectively (table 7). Recall, that these initial estimates were based upon previously reported data such as specific capacity and aquifer tests. Through the calibration process it was found that these initial values are reasonable and, therefore, were not changed.

As discussed earlier, the initial estimate of the anisotropy ratio was 100:1; that is, the horizontal hydraulic conductivity was 100 times greater than the vertical hydraulic conductivity. Other ratios were tested during the calibration process; however, this ratio did not have a significant impact and was not changed.

The initial estimates of storage for model layers $1-3$ were $0.1 \mathrm{ft} / \mathrm{ft}, 5.0 \times 10^{-6} \mathrm{ft}^{-1}$, and $1.0 \times 10^{-6} \mathrm{ft}^{-1}$, respectively. The first value is an estimate of $S_{y}$ for the unconfined model layer 1 , and the second and third values are estimates of $S_{S}$ for the confined model layers 2 and 3. Initially, storage was assumed to be homogeneous within a model layer; however, during the calibration process, it was determined that model layer 1 required three zones with $S_{y}$ values for each zone to match measured data (fig. 29). In addition, two sets of $S_{y}$ values were required for model layer 1; the first set was used to simulate the drawdown period 1956-1994 and the second set was used to simulate the water-level recovery period 1995-2001. The $S_{y}$ values for the midwest and the combined mideast, northeast, and east hydrogeologic units used to simulate the drawdown period are about half those used to simulate the water-level recovery period (fig. 29 and table 7). The upper aquifer became unsaturated during the period of 1956-94 and the water table was in the finergrained middle-aquifer portion of layer 1; thereby requiring the use of the lower $S_{y}$ value. After 1995 and the start of the artificial recharge program, the water table reentered the coarser-grained upper-aquifer portion of layer 1; thereby requiring the use of the higher $S_{y}$ values. 


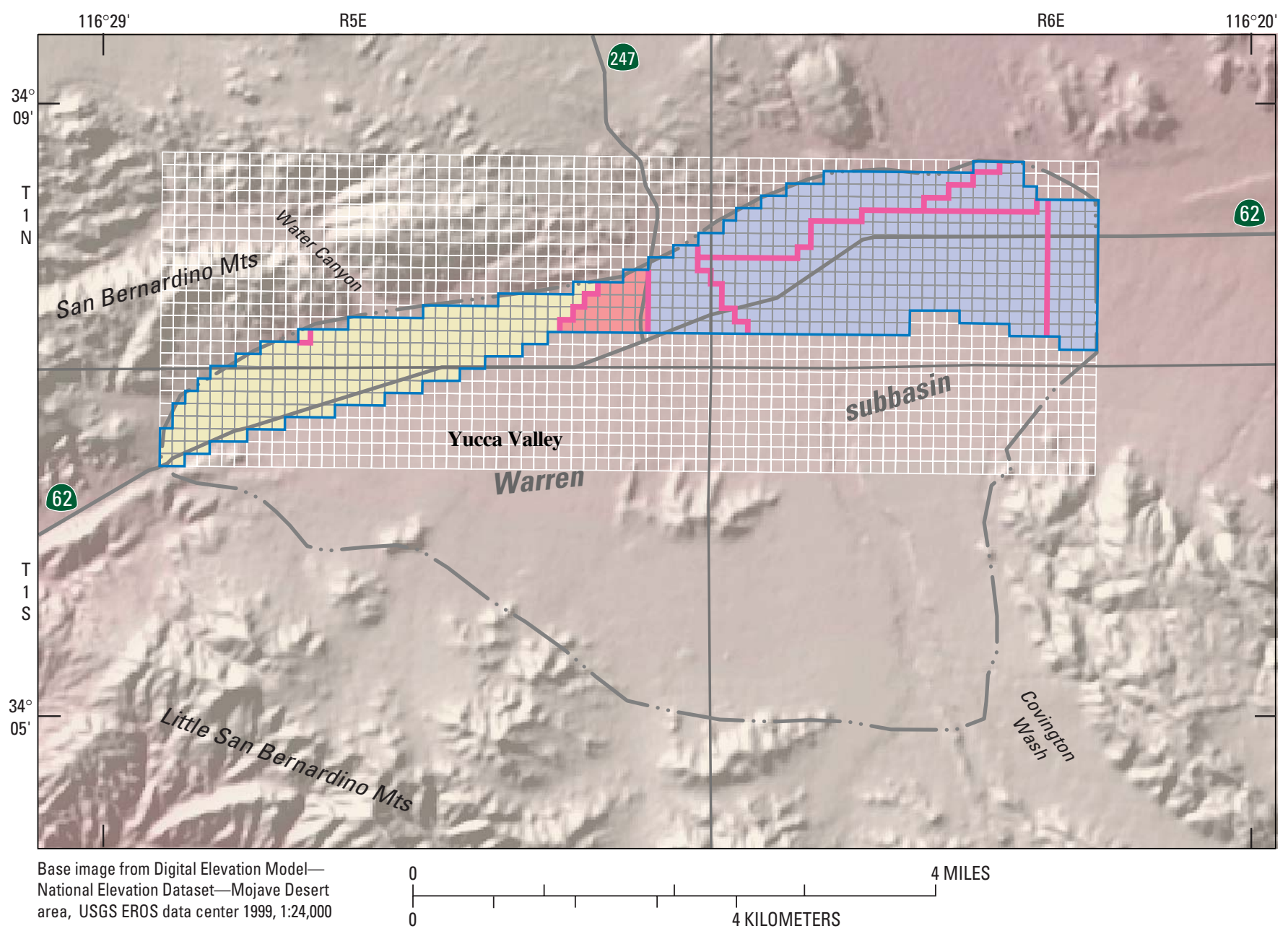

\section{EXPLANATION}

\begin{tabular}{|l|c|c|}
\multicolumn{1}{l|}{} & \multicolumn{3}{c|}{$\begin{array}{c}\text { Specific yield (unitless) } \\
\text { Drawdown } \\
(1956-1994)\end{array}$} & $\begin{array}{c}\text { Recovery } \\
(1995-2001)\end{array}$ \\
\hline West storage zone & .28 & .28 \\
\hline Midwest storage zone & .13 & .3 \\
\hline East storage zone & .13 & .3 \\
\hline
\end{tabular}

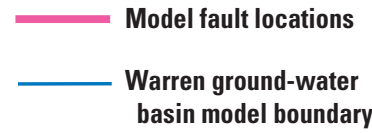

Figure 29. Specific yield of model layer 1 for drawdown (pre-1995) and recovery (post-1995) conditions, Warren ground-water basin, San Bernardino County, California. 
Flow across a simulated fault is proportional to the hydraulic characteristic (Hsieh and Freckleton, 1993). The initial hydraulic-characteristic values for all the faults in model-layer 1 were set equal to the hydraulic conductivity divided by the assumed width of the fault ( $1 \mathrm{ft}$ ), allowing unrestricted hydraulic connection across the faults (table 7). The initial hydraulic-characteristic values for all the faults in model-layers 2-3 were set equal to the maximum transmissivity value for each layer divided by the assumed width of the fault (1 ft), allowing unrestricted hydraulic connection across the faults (table 7). To reproduce the measured water levels and $\mathrm{NO} 3$ concentrations, it was necessary to simulate faults F1F7 (fig. 22) by decreasing the initial hydrauliccharacteristic values by as much as 11 orders of magnitude (table 7).

In order to better simulate the measured water levels, the estimated values for recharge of septage and irrigation return flow were modified from the land-use based initial values. It was assumed that none of the septage reached the water table and only one percent of the irrigation return flow from the golf course reached the water table from 1956 to 1994 (initially 100 percent was used for both sources of recharge) (artificial recharge in fig. 26). These changes were reasonable because $\mathrm{NO} 3$ concentrations were relatively unchanged from 1956 to the late-1980s; if higher septage recharge rates were used then simulated NO3 concentrations were higher than measured values. The thickness and large storage capacity of the unsaturated zone probably retarded the flow of septage and irrigation return flow. From 1995 to 2001,100 percent of the estimated recharge of septage and irrigation return flow were used in the simulation model. This was reasonable because the large increase in measured water levels decreased the travel time for septage and irrigation return flow to reach the water table.

\section{Simulated Fluxes}

Table 8 shows the simulated hydrologic budgets for each hydrogeologic unit and simulated flow rates between adjacent hydrogeologic units for the last stress period of predevelopment (1958), 1994, 1995, and 2001. Note that the predevelopment and 1994 simulations used annual stress periods and, therefore, the results reflect simulated flow rates at the end of those years. The 1995 and 2001 simulations used monthly stress periods and, therefore, the results reflect simulated flow rates on December 31 of those years.

For predevelopment conditions, the natural recharge was 83 acre- $\mathrm{ft} / \mathrm{yr}$ and the discharge was 86 acre-ft/yr of ground-water outflow across the Yucca Barrier (table $8 A$ ). The simulated flow was from west to east (table $8 B$ ). Note that under steady-state conditions, recharge should equal discharge; therefore, this small difference between simulated recharge and discharge ( 83 versus 86 acre-ft/yr) indicates that the model was approaching steady-state conditions after a 10,000 year simulation.

For 1994 conditions, the year prior to artificial recharge, the recharge rate was 97 acre- $\mathrm{ft} / \mathrm{yr}$ (83 acre$\mathrm{ft} / \mathrm{yr}$ of natural recharge and 14 acre-ft/yr of septage and irrigation return flow) and the discharge rate was $2,425 \mathrm{acre}-\mathrm{ft} / \mathrm{yr}(2,340 \mathrm{acre}-\mathrm{ft} / \mathrm{yr}$ of total pumpage and $85 \mathrm{acre}-\mathrm{ft} / \mathrm{yr}$ of ground-water outflow across the Yucca Barrier) (table 8A). The simulated flow rates between the hydrogeologic units was toward the pumping centers in the midwest and mideast hydrogeologic units (table 8B).

For December 1995 conditions, after about one year of artificial recharge, the total recharge was about 1,270 acre-ft ( 7 acre- $\mathrm{ft}$ of natural recharge, 222 acre-ft of septage and irrigation return flow, and 1,043 acre-ft of artificial recharge) and the total discharge was 122 acre-ft (115 acre-ft of pumpage and 7 acre-ft of ground-water outflow across the Yucca Barrier) (table $\underline{8 A})$. The artificial recharge in the midwest and mideast hydrogeologic units caused water to flow from the mideast hydrogeologic unit toward the midwest and east units (table 8B). Note that the flow rates leaving the midwest and mideast hydrogeologic units were small compared with the artificial-recharge rate of 1,040 acre-ft (table 8B). This indicates that nearly all the water recharged into the midwest and mideast hydrogeologic units remained in those units. 
Table 8A. Simulated recharge and discharge for the west, the midwest, the mideast, the northeast, and the east hydrogeologic units, Warren subbasin, California.

[*Figures reported in acre-feet per year; ** figures reported in acre-feet per month; italicized values are flows between hydrogeologic units and are not included in recharge, discharge, and storage depletion totals; negative storage depletion values indicate storage accretion (increase in volume of water in aquifer); discharge-recharge values differ from storage depletion values as a result of flow between adjacent hydrogeologic units and the rounding of large numbers]

\begin{tabular}{|c|c|c|c|c|c|c|}
\hline & West & Midwest & Mideast & Northeast & East & Total \\
\hline \multicolumn{7}{|l|}{ Predevelopment* } \\
\hline \multicolumn{7}{|l|}{ Recharge } \\
\hline Septage and irrigation return & .0 & .0 & .0 & .0 & .0 & .0 \\
\hline Artificial & .0 & .0 & .0 & .0 & .0 & .0 \\
\hline Total & 7.7 & 8.6 & 32.6 & 34.3 & 0.0 & 83.2 \\
\hline \multicolumn{7}{|l|}{ Discharge } \\
\hline Pumpage & .0 & .0 & .0 & .0 & .0 & .0 \\
\hline Head-dependent boundary & .0 & .0 & .0 & .0 & 86.0 & 86.0 \\
\hline Storage depletion & 1.6 & .1 & .1 & .2 & .6 & 2.6 \\
\hline \multicolumn{7}{|l|}{$1994 *$} \\
\hline \multicolumn{7}{|l|}{ Recharge } \\
\hline Natural & 7.7 & 8.6 & 32.6 & 34.3 & .0 & 83.2 \\
\hline Septage and irrigation return & 11.3 & .9 & .9 & .2 & .9 & 14.2 \\
\hline Artificial & .0 & .0 & .0 & .0 & .0 & .0 \\
\hline Inflow from adjacent hydrogeologic units & 64.9 & 482.3 & 4.8 & 9.6 & 30.7 & \\
\hline Total & $1,230.7$ & 868.2 & 226.8 & 13.8 & 85.4 & $2,424.9$ \\
\hline Discharge-recharge & $1,211.7$ & 858.7 & 193.3 & -20.7 & 84.5 & $2,327.5$ \\
\hline Storage depletion & $1,359.7$ & 441.4 & 457.6 & 1.0 & 66.6 & $2,326.3$ \\
\hline
\end{tabular}


Table 8A. Simulated recharge and discharge for the west, the midwest, the mideast, the northeast, and the east hydrogeologic units, Warren subbasin, California.-Continued

[*Figures reported in acre-feet per year; ** figures reported in acre-feet per month; italicized values are flows between hydrogeologic units and are not included in recharge, discharge, and storage depletion totals; negative storage depletion values indicate storage accretion (increase in volume of water in aquifer); discharge-recharge values differ from storage depletion values as a result of flow between adjacent hydrogeologic units and the rounding of large numbers]

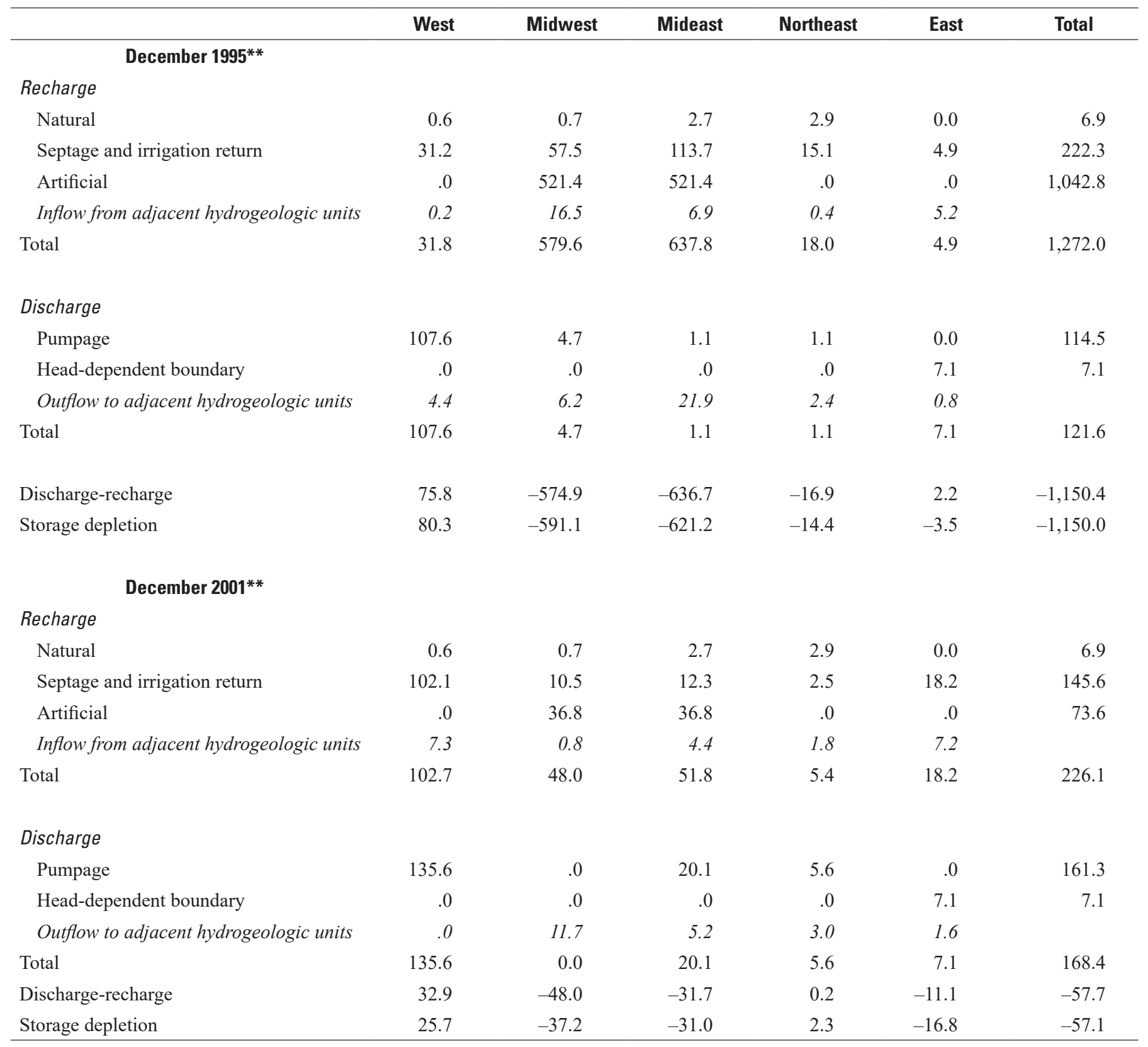


Table 8B. Simulated flow rates between hydrogeologic units for predevelopment, 1994, 1995, and 2001.

[*Flow rate is reported in acre-feet per year; ** flow rate is reported in acre-feet per month; positive number indicating "from to" flow direction]

\begin{tabular}{|c|c|c|}
\hline \multicolumn{3}{|c|}{ Predevelopment* } \\
\hline From & To & Flowrate \\
\hline West & Midwest & 9.4 \\
\hline Mideast & East & 49.0 \\
\hline Northeast & East & 36.3 \\
\hline Ground-water underflow past Yucca Barrier & & 86.0 \\
\hline \multicolumn{3}{|c|}{$1994^{*}$} \\
\hline From & To & Flowrate \\
\hline West & Midwest & 149.3 \\
\hline Midwest & Mideast & -277.7 \\
\hline Ground-water underflow past Yucca Barrier & & 85.4 \\
\hline \multicolumn{3}{|c|}{ December 1995** } \\
\hline From & To & Flowrate \\
\hline West & Midwest & 4.4 \\
\hline Midwest & Mideast & -11.7 \\
\hline Mideast & East & 4.0 \\
\hline Northeast & East & 1.6 \\
\hline Northeast & Mideast & .1 \\
\hline Northeast & East & 1.4 \\
\hline Northeast & Mideast & -0.2 \\
\hline Ground-water underflow past Yucca Barrier & & 7.1 \\
\hline
\end{tabular}


For the December 2001 conditions, after seven years of artificial recharge, the total recharge was 226 acre- $\mathrm{ft}$ ( 7 acre- $\mathrm{ft}$ of natural recharge, 145 acre- $\mathrm{ft}$ of septage and irrigation return flow, and 74 acre- $\mathrm{ft}$ of artificial recharge) and the total discharge was 168 acre-ft (161 acre-ft of pumpage and 7 acre-ft of ground-water outflow across the Yucca Barrier) (table $\underline{8 A})$. The continued artificial recharge in the midwest and mideast hydrogeologic units caused water to flow from the midwest to the west hydrogeologic unit and from the mideast to east and northeast hydrogeologic units (table 8B). Similar to the 1995 results, the simulated results indicate that the majority of water recharged into the midwest and mideast hydrogeologic units remained in those units (table $\underline{8 B})$. The simulated 1995 and 2001 results indicate that the interior faults (F2, F3, and F4) restrict the flow of the artificial-recharge water exiting the midwest and the mideast hydrogeologic units.

\section{Simulated Hydraulic Heads}

Simulated hydraulic heads and measured water levels for selected wells are shown in figure 30 of which only wells 1N/5E-36K1 (HDWD-1) and 36K2 (9E) in the midwest hydrologic unit had a long-term record. Well 1S/5E-3D1 (8W) is in the west hydrogeologic unit and is perforated in model-layers 1 and 2 . The simulated hydraulic heads declined about $150 \mathrm{ft}$ from 1956 to 1995 (fig. 30A). After the start of the artificial recharge program in February 1995, the simulated hydraulic head declined an additional $15 \mathrm{ft}$ from 1995 to 2001; however, this was a lower rate than that for previous years. Measured water levels showed a slight increase during the period 1995-2001.

Wells 1N/5E-36K1 (HDWD-1) and 36K2 (9E) are in the midwest hydrogeologic unit (fig. 1). Well 36K1 was drilled in 1946, destroyed in 1976, and was perforated in model layer 1 . Well $36 \mathrm{~K} 2$ was drilled in 1975, is close to 36K1 (within the same grid cell) (fig. 1 ), and is perforated in model layers 1 and 2 . The simulated hydraulic heads for model layers 1 and 2 are similar to the measured water levels with a total decline of about $300 \mathrm{ft}$ from 1956 to 1995, capturing more than 90 percent of the measured drawdown (fig. $30 \mathrm{~B}$ ). The slope in the measured water-level data changes in the mid-1980s when the upper aquifer became unsaturated (below 2,900 ft). An additional model layer would be required to simulate this measured response to pumpage. After the start of the artificial recharge program in February 1995, the simulated hydraulic head increased 290-300 ft from 1995 to 2001, showing a trend similar to that of the measured water levels.

Well $1 \mathrm{~N} / 5 \mathrm{E}-36 \mathrm{H} 2(18 \mathrm{E})$ is located in the mideast hydrogeologic unit and is perforated in model-layers 1 and 2, with most of the perforated interval in modellayer 2 . The simulated hydraulic heads for model-layer 2 declined about $230 \mathrm{ft}$ from 1956 to 1995 (fig. 30C). After the start of the artificial recharge program in February 1995, the simulated hydraulic head increased about $210 \mathrm{ft}$ from 1995 to 2001, showing a trend similar to that of the measured water levels.

Well 1N/6E-31C1 (5E) is located in the northeast hydrogeologic unit and is perforated in model-layers 1 and 2 . The simulated hydraulic heads declined about $55 \mathrm{ft}$ from 1956 to 1995 (fig. 30D). After the start of the artificial recharge program in February 1995, the simulated hydraulic head showed a slight increase from 1995 to 2001, whereas the measured water levels showed an increase of more than $50 \mathrm{ft}$.

\section{Model Fit}

Measured water levels and simulated transientstate hydraulic heads for predevelopment (1958), 1994, 1998, and 2000 are shown by hydrogeologic unit with the 1:1 correlation line (fig. 31). If the model simulated measured data perfectly, then all data would lie on the 1:1 correlation line. For figure 31, if the well in which the water-level was measured was perforated in more than one aquifer, the measured water level from that well was compared to the simulated hydraulic head from the uppermost aquifer perforated by that well. 

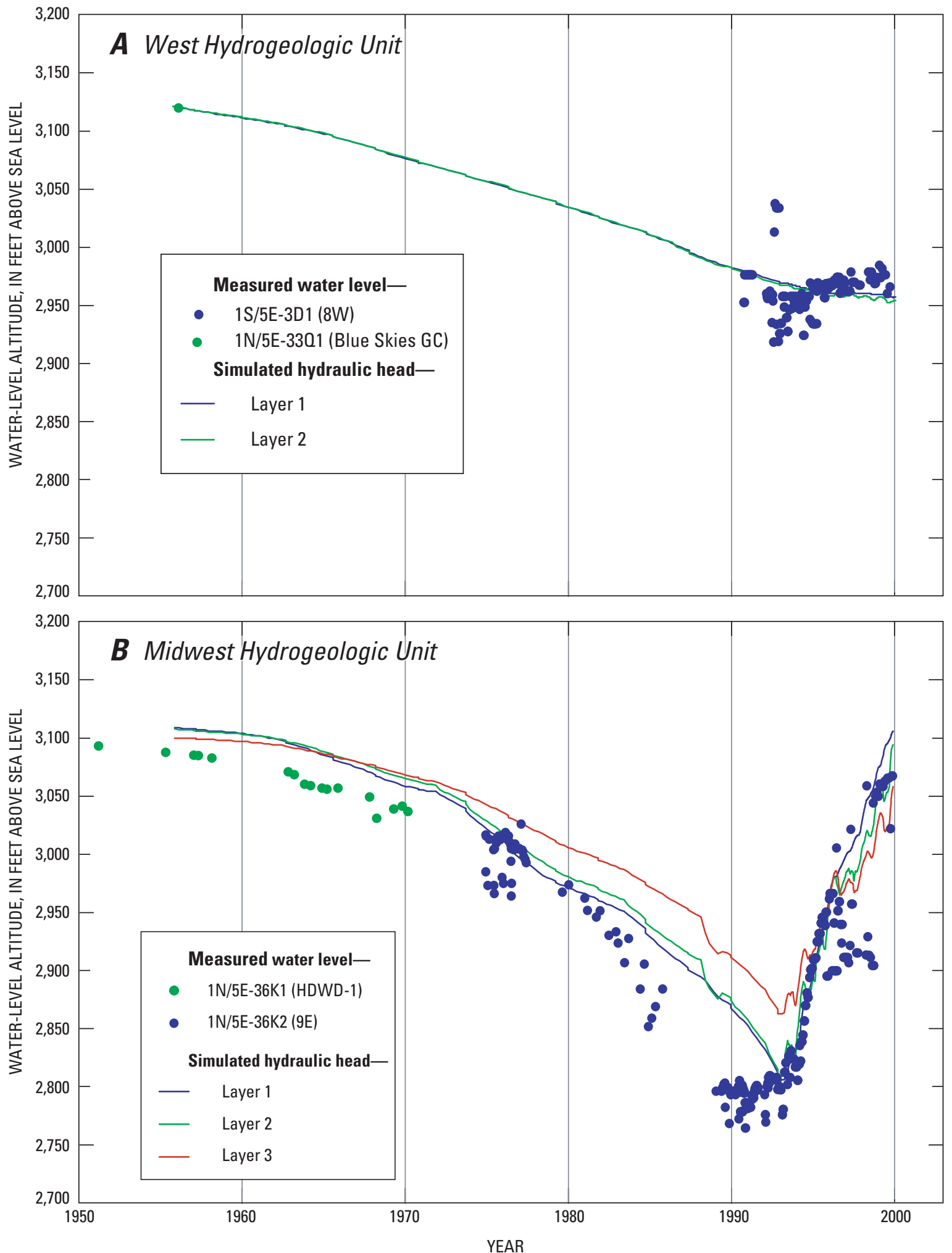

Figure 30. Measured water levels and simulated hydraulic heads for $(A)$ 1S/5E-3D1 (8W), (B) 1N/5E-36K1 (HDWD-1) and 36K2 (9E), (C) 1N/5E-36H2 (18E), and $(D) 1 \mathrm{~N} / 6 \mathrm{E}-31 \mathrm{C1}(5 \mathrm{E})$, Warren ground-water basin, San Bernardino County, California. 

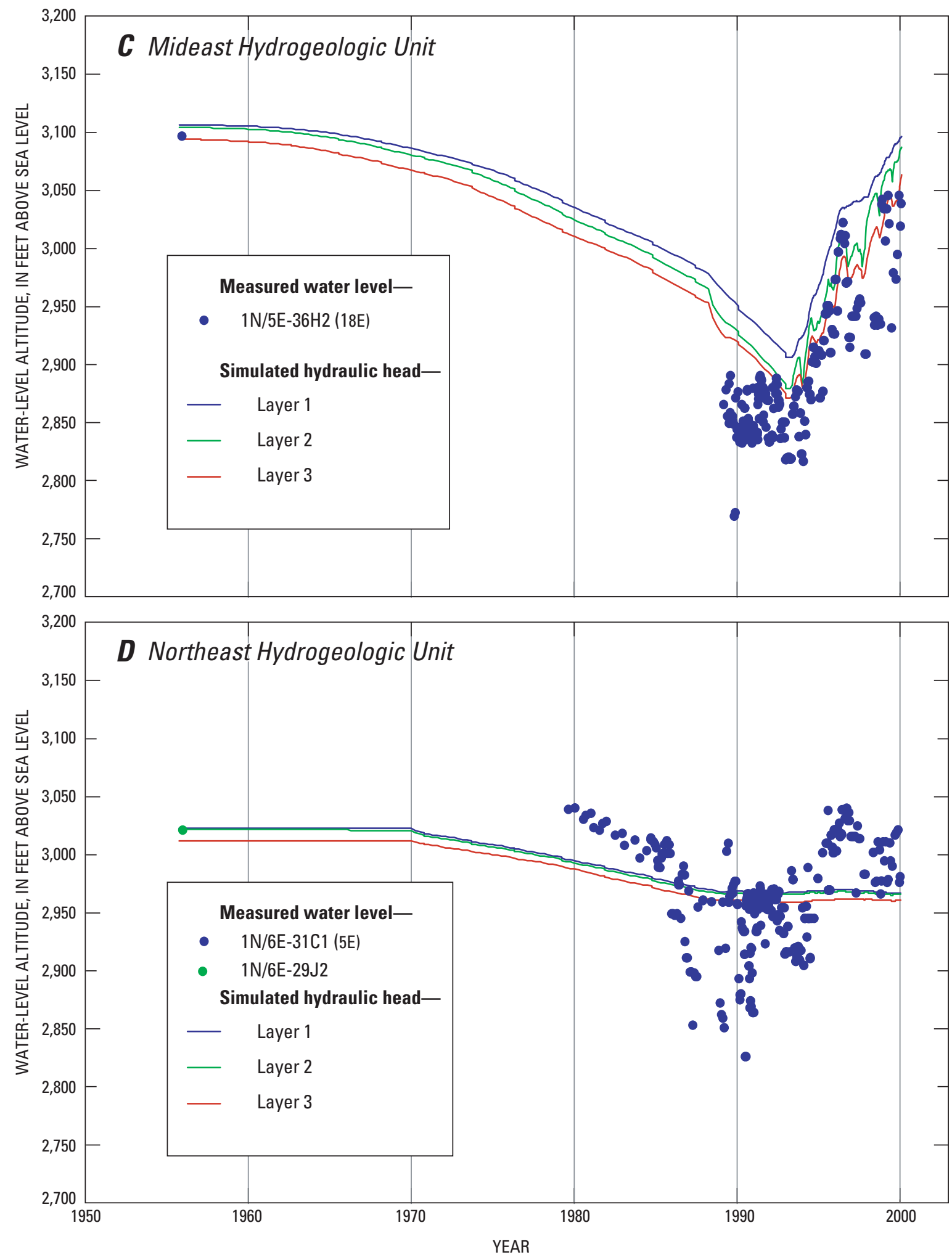

Figure 30.-Continued. 

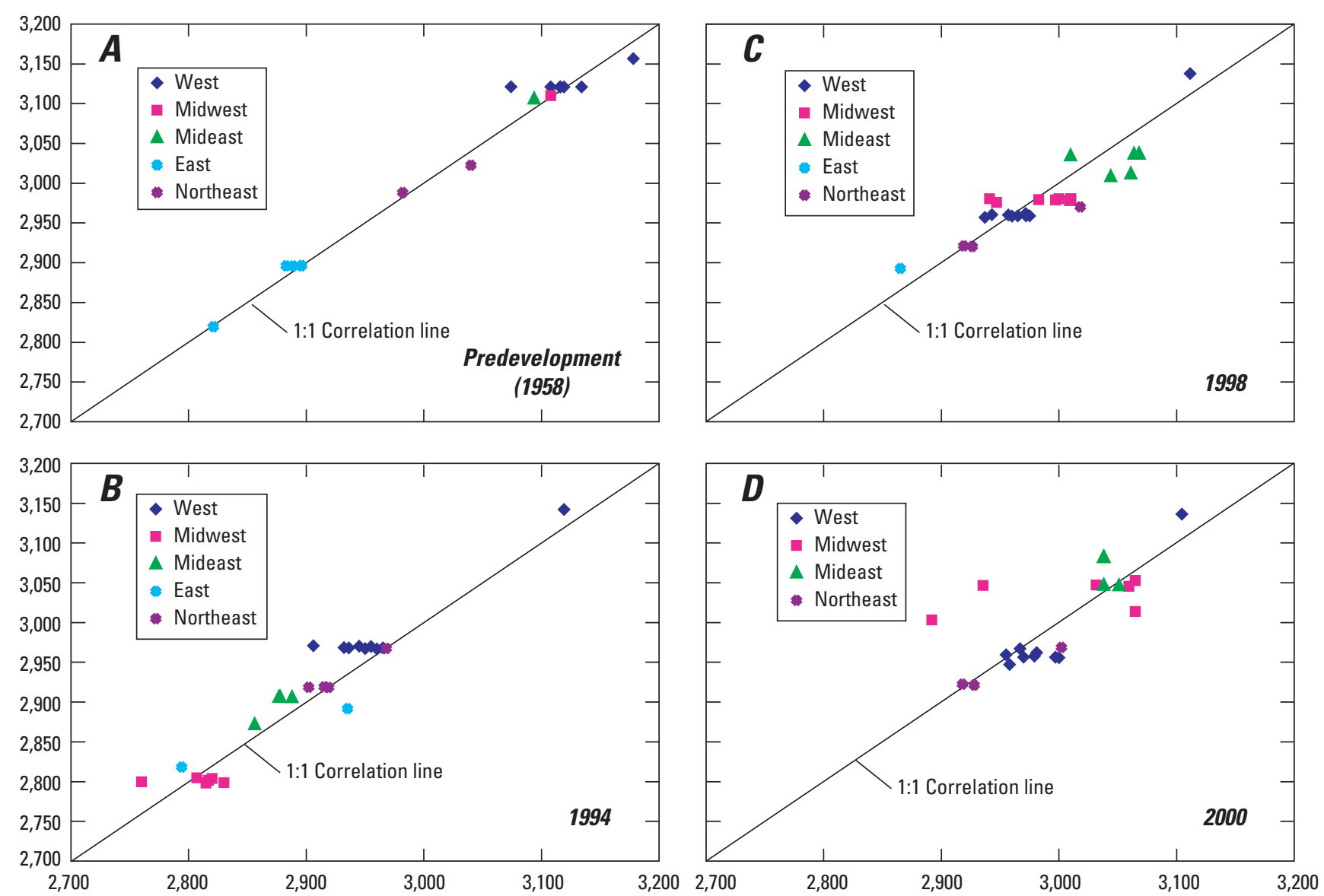

MEASURED WATER-LEVEL ALTITUDES, IN FEET ABOVE SEA LEVEL

Figure 31. Simulated hydraulic head and measured water levels for: $(A)$ 1958, $(B)$ 1994, $(C)$ 1998, and $(D)$ 2000, Warren ground-water basin, San Bernardino County, California. 
For the predevelopment (1958) data, the rootmean-squared error (RMSE) was about $18 \mathrm{ft}$. In the west hydrogeologic unit, with the exception of well $1 \mathrm{~N} / 5 \mathrm{E}-34 \mathrm{~K} 1(2 \mathrm{~W})$, the simulated hydraulic heads were within $\pm 15 \mathrm{ft}$ of measured water levels. The waterlevel measurement at 34K1 may reflect pumping conditions. In the midwest and mideast hydrogeologic units there was only one water-level measurement available in each hydrogeologic unit. The simulated hydraulic head in the midwest hydrogeologic unit was $2 \mathrm{ft}$ greater than the measured water level and the simulated hydraulic head in the mideast hydrogeologic unit was $12 \mathrm{ft}$ greater than the measured water level. In the east hydrogeologic unit, the simulated hydraulic heads were $0-13 \mathrm{ft}$ greater than measured water levels. In the northeast hydrogeologic unit, two water-level measurement were available (wells 1N/6E-29J2 west of fault F7 and 29L1 east of fault F7); the simulated hydraulic head for well 29J2 was $6 \mathrm{ft}$ greater than measured data and the simulated hydraulic head for well 29L1 was $17 \mathrm{ft}$ less than measured data.

For the 1994 data, the RMSE was about $27 \mathrm{ft}$. In the west hydrogeologic unit, the simulated hydraulic heads were greater than measured data by 3-66 ft; the largest difference was at well 1N/5E-35K1 (11W). The measured water level at well $35 \mathrm{~K} 1$ was as much as $54 \mathrm{ft}$ lower than measured water levels from adjacent wells in the west hydrogeologic unit suggesting that this well may have been recently pumped. In the midwest hydrogeologic unit, the simulated hydraulic heads were less than the measured water levels by 3-30 ft with the exception of well 1N/5E-36M5 (16E), which was overestimated by $42 \mathrm{ft}$. The measured water level at well 36M5 was as much as $70 \mathrm{ft}$ lower than measured water levels from adjacent wells in the midwest hydrogeologic unit suggesting that this well may have been recently pumped. In the mideast hydrogeologic unit, the simulated hydraulic heads overestimated the measured data by as much as $30 \mathrm{ft}$. In the east hydrogeologic unit, the difference between the simulated hydraulic heads and measured water levels ranged from $24 \mathrm{ft}$ overestimation to $44 \mathrm{ft}$ underestimation. In the northeast hydrogeologic unit, the difference between simulated hydraulic heads and measured water levels ranged from $16 \mathrm{ft}$ overestimation to less than $1 \mathrm{ft}$ underestimation.
For the 1998 data, the RMSE was about $27 \mathrm{ft}$. In the west hydrogeologic unit, simulated hydraulic heads ranged from $14 \mathrm{ft}$ less to $27 \mathrm{ft}$ greater than measured water levels. In the midwest hydrogeologic unit, most of the simulated hydraulic heads underestimated measured data; the greatest difference was about $32 \mathrm{ft}$ at well 1N/5E-36M3 (YV2-300). In the mideast hydrogeologic unit, most of the simulated hydraulic heads were underestimated; the greatest difference was about $50 \mathrm{ft}$ 1N/5E-36G1 (YV1-570). The underestimation in the midwest and mideast hydrogeologic units at the YV1 and YV2 wells near the recharge ponds may be the result of using too large of specific yield values to simulate the water-level recovery. In reality, there would be a higher moisture content beneath the ponds; therefore, there would be less available pore space to fill with rising water, which, in turn, would mean that the specific yield should be lower beneath the ponds. In the east hydrogeologic unit, the simulated hydraulic head overestimated the only measured water level by $28 \mathrm{ft}$. In the northeast hydrogeologic unit, the simulated hydraulic heads underestimated measured water levels by $6-48 \mathrm{ft}$.

For the 2000 data, the RMSE was about $42 \mathrm{ft}$. In the west hydrogeologic unit, the simulated hydraulic heads ranged from $45 \mathrm{ft}$ less to $32 \mathrm{ft}$ greater than measured water levels. In the midwest hydrogeologic unit, the simulated hydraulic heads ranged from $52 \mathrm{ft}$ less to $111 \mathrm{ft}$ greater than measured water levels. The largest differences occurred at wells 1N/5E-36L1 (7E) and 36M5 (16E). The measured water level at wells $36 \mathrm{~L} 1$ and 36M5 were as much as $130 \mathrm{ft}$ and $140 \mathrm{ft}$, respectively, lower than measured water levels from adjacent wells in the midwest hydrogeologic unit; these data may reflect pumping or recently pumped conditions as the water-level data collected in 1998 were about 65 and $55 \mathrm{ft}$ higher. In the mideast hydrogeologic unit, the simulated hydraulic heads ranged from $5 \mathrm{ft}$ less to $43 \mathrm{ft}$ greater than the measured water levels. In the east hydrogeologic unit, there were no measured water levels available. In the northeast hydrogeologic unit, the simulated hydraulic heads ranged from $34 \mathrm{ft}$ less to $4 \mathrm{ft}$ greater than the measured water levels. 


\section{Solute-Transport Model}

There are no predevelopment measurements of $\mathrm{NO}_{3}$ concentrations; therefore, background $\mathrm{NO}_{3}$ concentrations were assumed to be about $10 \mathrm{mg} / \mathrm{L}$. It also was assumed that all natural recharge had a $\mathrm{NO}_{3}$ concentration of $10 \mathrm{mg} / \mathrm{L}$. After a predevelopment simulation of 10,000 years, the simulated $\mathrm{NO}_{3}$ concentration were about $9.8 \mathrm{mg} / \mathrm{L}$ throughout the ground-water basin. Measured $\mathrm{NO}_{3}$ concentrations from 1965 to 2001 were used to calibrate the solutetransport model for transient conditions caused by hydraulic and hydrochemical stresses within the basin.

From 1956 to 2001, the sources of $\mathrm{NO}_{3}$ included infiltration of irrigation return flow, septage, imported water, and the entrained unsaturated-zone water. In order to better simulate the measured 1956-94 $\mathrm{NO}_{3}$ concentrations, the initial estimation for the concentration of the irrigation return flow from the golf course was decreased by 50 percent from $90 \mathrm{mg} / \mathrm{L}$ to $45 \mathrm{mg} / \mathrm{L}$. Recall that the flow-calibration results indicated that none of the septage reached the water table and one percent of the irrigation return flow from the golf course reached the water table from 1956 to 1994, whereas 100 percent of the septage and irrigation return flow reached the water table from 1995 to 2001. In total, these changes were reasonable because $\mathrm{NO}_{3}$ concentrations were relatively unchanged from 1956 to the late-1980s; if higher $\mathrm{NO}_{3}$ concentrations are used and a greater percentage of irrigation return flow is allowed to reach the water table, then the simulated $\mathrm{NO}_{3}$ concentrations were higher than measured values. From 1995 to 2001, 50 percent of the estimated $\mathrm{NO}_{3}$ concentrations of septage and irrigation return flow were used in the solute-transport model yielding a better match for this time period.

The artificial recharge program started in 1995 and the associated $\mathrm{NO}_{3}$ concentration of the imported water was assumed to equal $2 \mathrm{mg} / \mathrm{L}$. The $\mathrm{NO}_{3}$ concentration of the captured unsaturated-zone water was estimated using equation 5 . The $\mathrm{NO}_{3}$ concentrations of the septage and the entrained unsaturated-zone water from beneath commercial, residential, and multi-family land uses are unknown. Published reports indicate that the $\mathrm{NO}_{3}$ concentration of septage may range from $220 \mathrm{mg} / \mathrm{L}$ (Umari and others, 1995) to $350 \mathrm{mg} / \mathrm{L}$ (Bouwer, 1978). Therefore, two simulations were made using the two concentration values.

Contours representing simulated July $2001 \mathrm{NO}_{3}$ concentrations for model-layer 1 assuming source concentrations 220 and $350 \mathrm{mg} / \mathrm{L}$ for the septage and the entrained unsaturated-zone water are compared with measured $\mathrm{NO}_{3}$ concentrations for July and August 2001 (fig. 32). Simulated $\mathrm{NO}_{3}$ concentrations, assuming $\mathrm{NO}_{3}$ concentrations of 220 and $350 \mathrm{mg} / \mathrm{L}$ for the septage and the entrained unsaturated-zone water from beneath commercial, residential, and multi-family land uses, were compared with available measured $\mathrm{NO}_{3}$ concentrations for selected wells for the simulation period 1956-2001 (fig. 33). In figure 33, the simulated concentrations for the three model layers are presented for the selected well sites. For this study, such time-varying $\mathrm{NO}_{3}$ concentration data are referred to as chemographs.

In the west hydrogeologic unit, the simulated model-layer $1 \mathrm{NO}_{3}$ concentrations for both 220 and $350 \mathrm{mg} / \mathrm{L}$ is similar to the $\mathrm{NO}_{3}$ concentrations measured in July and August 2001 (fig. $32 A$ and $\underline{B}$ ). The simulated model-layer 2 chemographs for well $1 \mathrm{~S} / 5 \mathrm{E}-3 \mathrm{D} 1$ (8W), in the western part of the west hydrogeologic unit, show almost no change and are similar to the measured $\mathrm{NO}_{3}$ concentrations (fig. 33A). Well 3D1 is perforated in model-layers 1 and 2, and only the upper $40 \mathrm{ft}$ of the perforated interval is in the lower part of model-layer 1; therefore, the measured data reflects model-layer 2 . The simulated modellayer $1 \mathrm{NO}_{3}$ concentrations approach $20 \mathrm{mg} / \mathrm{L}$ by 2001 for both 220 and $350 \mathrm{mg} / \mathrm{L}$, and are similar to the measured value at well $1 \mathrm{~S} / 5 \mathrm{E}-4 \mathrm{~A} 1$, which is perforated mostly in model-layer 1 (figs. $32 A$ and $\underline{B}$ ). 


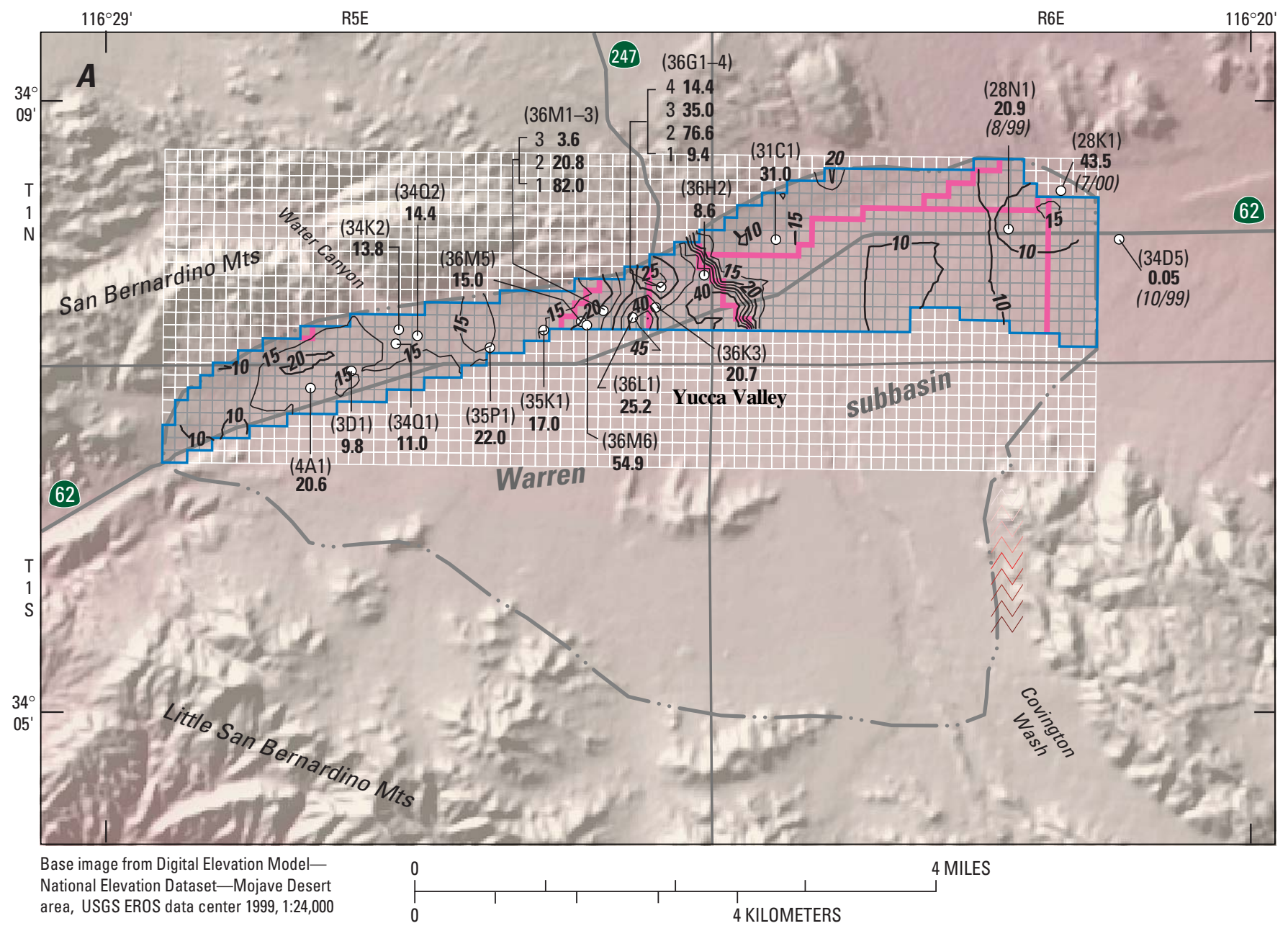

EXPLANATION

\begin{tabular}{|l}
\hline$\square$ Active cells \\
\hline$\square \quad$ Inactive cells \\
Model fault locations \\
Warren ground-water \\
basin model boundary
\end{tabular}

- 20 - Line of equal simulated nitrate concentration for initial septage equal to $220 \mathrm{mg} / \mathrm{L}$ in model layer 1 -In milligrams per liter

(35P1) Monitoring well designation and nitrate concentration

$0^{22.0}$ (July and August 2001, unless otherwise noted)—In milligrams per liter

Figure 32. Nitrate concentrations measured in July and August 2001 and contours of simulated model-layer 1 nitrate concentrations for July 2001 assuming a nitrate concentration for septage and entrained unsaturated zone water of $(A) 220 \mathrm{mg} / \mathrm{L}$ and $(B) 350 \mathrm{mg} / \mathrm{L}$, Warren ground-water basin, San Bernardino County, California. 


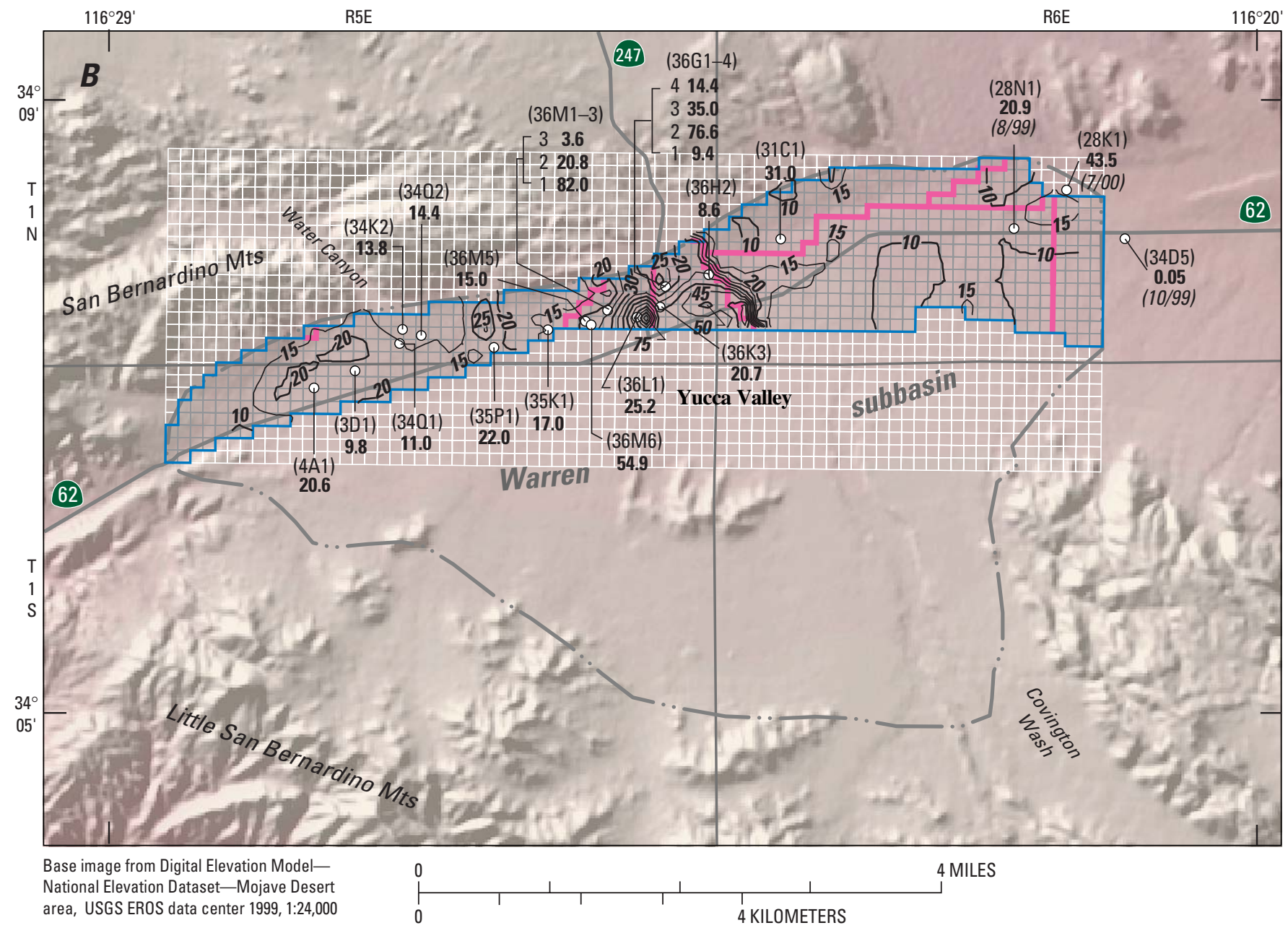

\section{EXPLANATION}

\begin{tabular}{|ll}
\hline$\square$ & Active cells \\
\hline$\square \quad$ Inactive cells \\
\hline$\square \quad$ Model fault locations \\
Warren ground-water \\
basin model boundary
\end{tabular}

$-20-$ Line of equal simulated nitrate concentration for initial septage equal to $350 \mathrm{mg} / \mathrm{L}$ in model layer 1 - In milligrams per liter

(35P1)

$0^{22.0}$

\section{Monitoring well designation and nitrate concentration} (July and August 2001, unless otherwise noted)—In milligrams per liter

Figure 32.-Continued. 

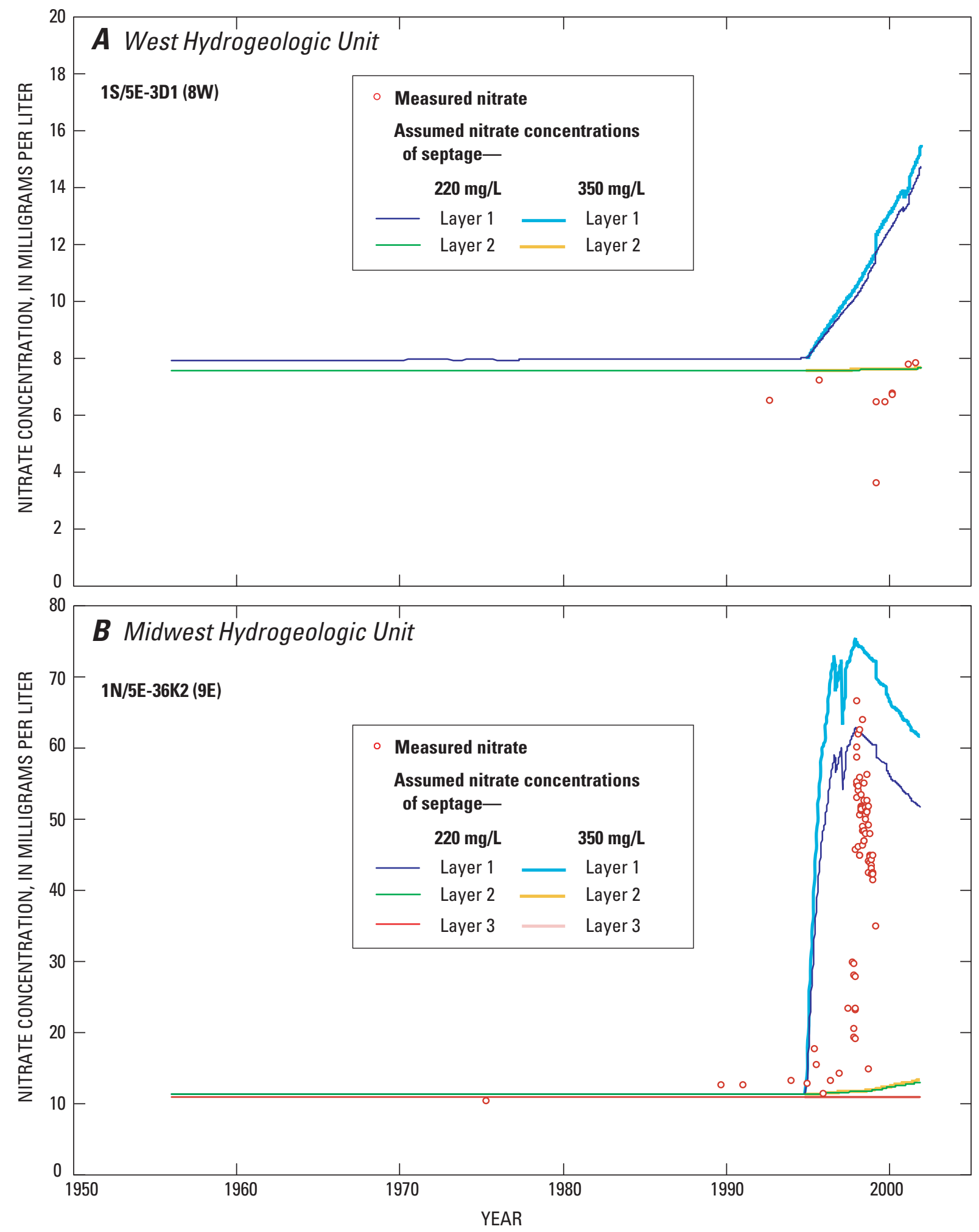

Figure 33. Simulated and measured nitrate concentrations assuming the nitrate concentrations of the septage were 220 and $350 \mathrm{mg} / \mathrm{L}$ for $(A) 1 S / 5 E-3 D 1$ (8W), (B) 1N/5E-36K2 (9E), (C) 1N/5E-36M5 (16E), (D) 1N/5E-36H2 (18E), (E) 1N/5E-36K3 (14E), and (F) 1N/6E-31C1 (5E), Warren ground-water basin, San Bernardino County, California. 

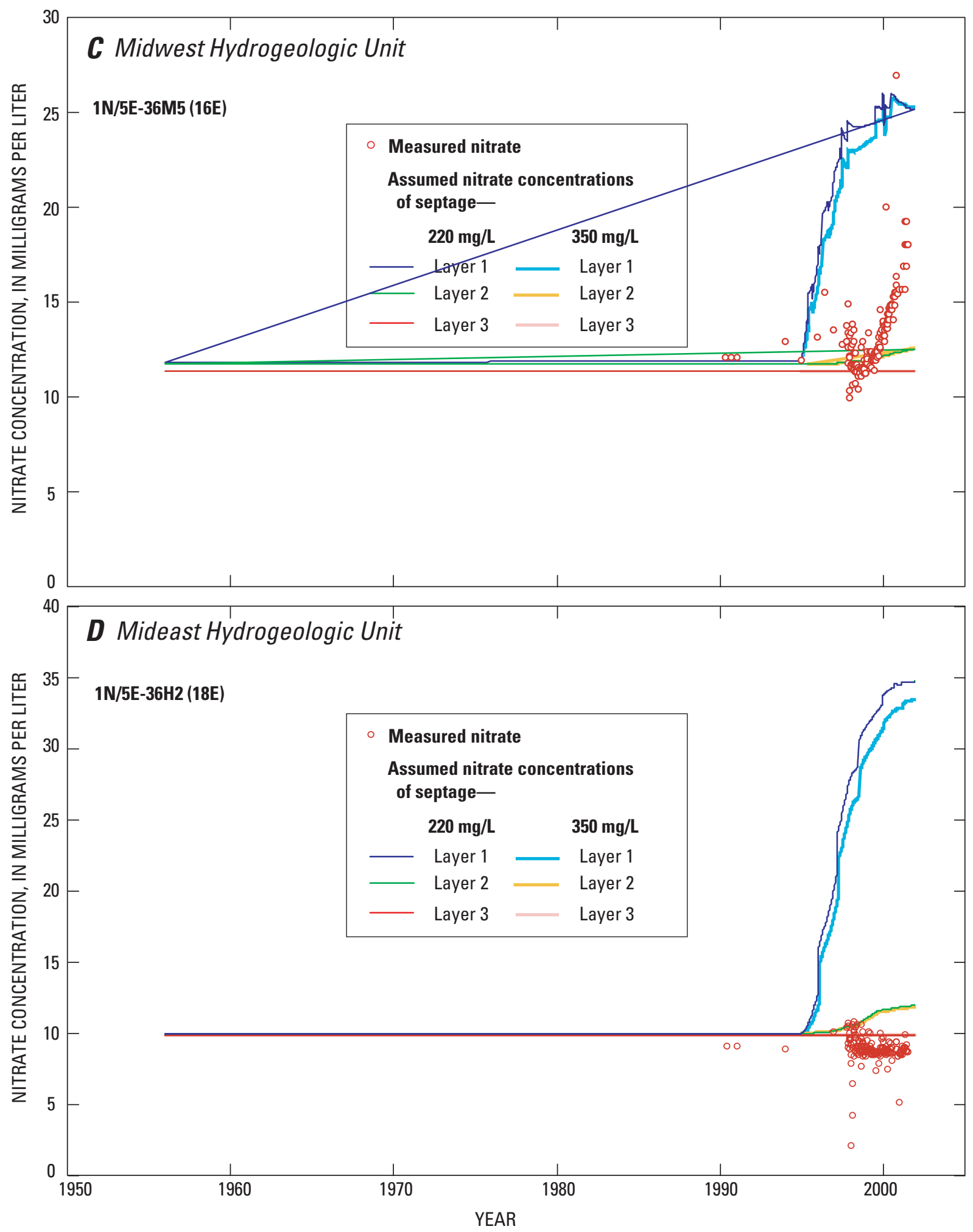

Figure 33.-Continued. 

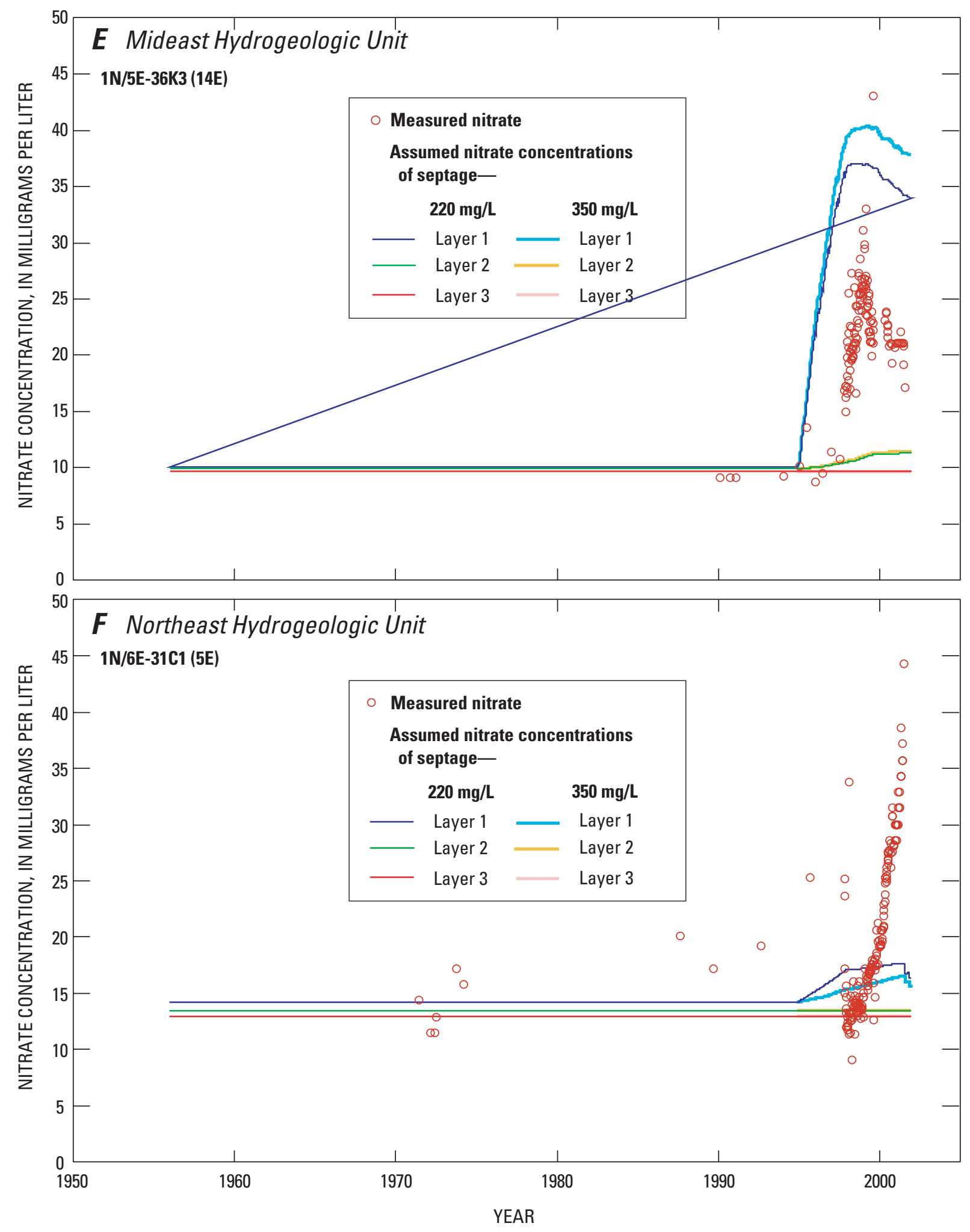

Figure 33.-Continued. 
In the midwest hydrogeologic unit, the simulated model-layer $1 \mathrm{NO}_{3}$ concentrations for both 220 and $350 \mathrm{mg} / \mathrm{L}$ are similar to the $\mathrm{NO}_{3}$ concentrations measured in July and August 2001, with the exception of the shallow well at the multiple-well monitoring site 1N/5E-36M1-3 [36M3 (YV2-300)] (fig. 32A and $\underline{B}$ ). The simulated July $2001 \mathrm{NO}_{3}$ concentrations for well $36 \mathrm{M} 3$ were about $15 \mathrm{mg} / \mathrm{L}$ lower than the measured $\mathrm{NO}_{3}$ concentrations (fig. $32 A$ and $\underline{B}$ ). The simulated model-layer 1 chemographs for well 1N/5E-36K2 (9E) reflect the timing of the increase in measured $\mathrm{NO}_{3}$ concentrations; however, the results from the $350 \mathrm{mg} / \mathrm{L}$ simulation overestimate the peak concentration, and the results from the $220 \mathrm{mg} / \mathrm{L}$ simulation underestimate the peak concentration (fig. 33B). The simulated model-layer 2 and 3 chemographs show little-to-no change (fig. $33 \mathrm{~B}$ and $\underline{C}$ ). However, the measured $\mathrm{NO}_{3}$ concentrations for well 1N/5E-36M5 (16E), perforated in model-layers 2 and 3, show an increase of more than $5 \mathrm{mg} / \mathrm{L}$ starting in early 2000 and approach the peak simulated $\mathrm{NO}_{3}$ concentrations for model-layer 1 (fig. $\underline{33 C}$ ). The measured increase in $\mathrm{NO}_{3}$ concentrations for well 36M5 may be the result of downward migration of high- $\mathrm{NO}_{3}$ water through the well gravel pack.

In the mideast hydrogeologic unit, the simulated model-layer $1 \mathrm{NO}_{3}$ concentrations for both 220 and $350 \mathrm{mg} / \mathrm{L}$ are similar to the $\mathrm{NO}_{3}$ concentrations measured in July and August 2001, with the exception of the two deepest wells perforated in model-layer 1 at the multiple-well monitoring site 1N/5E-36G1-4 [36G2 (YV1-400) and 36G3 (YV1-305) see fig. 6] (fig. 32A and $\underline{B}$ ). The simulated August $2001 \mathrm{NO}_{3}$ concentration at well 36G2 was about $60 \mathrm{mg} / \mathrm{L}$ lower than measured $\mathrm{NO}_{3}$ concentration and simulated August $2001 \mathrm{NO}_{3}$ concentration at well 36G3 was about $20 \mathrm{mg} / \mathrm{L}$ higher than the measured $\mathrm{NO}_{3}$ concentration (fig. $32 A$ and $\underline{B}$ ). The measured, peak $\mathrm{NO}_{3}$ concentrations at wells 36G2-4 ranged from 133-150 mg/L (fig. 15A), whereas the simulated, peak $\mathrm{NO}_{3}$ concentrations for this well were about $26 \mathrm{mg} / \mathrm{L}$. A possible explanation for the underestimation of the measured, peak $\mathrm{NO}_{3}$ concentrations at wells $36 \mathrm{G} 2-4$ is the manner in which the recharge flux associated with the entrained septage captured by the measured waterlevel rise was simulated; that is, the recharge flux was estimated based upon the overlying land use. Figure 2 shows the 1993 land use. Note that there is little development in the area surrounding recharge site 7 near wells 36G2-4 (fig. 2); therefore, the recharge flux of the entrained septage would be low because the assumed moisture content beneath undeveloped areas was low (0.02 versus 0.15$)$.

There are two production wells in the mideast hydrogeologic unit, 1N/5E-36H2 (18E) and 36K3 (14E); well $36 \mathrm{H} 2$ is perforated almost entirely in model-layer 2 and well $36 \mathrm{~K} 3$ is perforated entirely in model-layer 2. The simulated model-layer $1 \mathrm{NO}_{3}$ concentration for well $36 \mathrm{H} 2$ overestimated the measured $\mathrm{NO}_{3}$ concentration by about $25 \mathrm{mg} / \mathrm{L}$ (fig. 33D). Although well 36K3 is perforated entirely in model-layer 2, the simulated model-layer 1 chemographs reflect the timing of the increase in measured $\mathrm{NO}_{3}$ concentrations, with both the results from the 220 and $350 \mathrm{mg} / \mathrm{L}$ simulations underestimating the peak $\mathrm{NO}_{3}$ concentration by about 7 and $3 \mathrm{mg} / \mathrm{L}$, respectively (fig. 33E). The measured increase in $\mathrm{NO}_{3}$ concentrations for well $36 \mathrm{~K} 3$ may be the result of downward migration of high- $\mathrm{NO}_{3}$ water through the well gravel pack. The simulated $\mathrm{NO}_{3}$ concentrations for model-layers 2 and 3 showed littleto-no change for wells $36 \mathrm{H} 2$ and $36 \mathrm{~K} 3$ (fig. $33 \mathrm{D}, \underline{E}$ ).

In the east and northeast hydrogeologic units, the simulated model-layer $1 \mathrm{NO}_{3}$ concentrations for both 220 and $350 \mathrm{mg} / \mathrm{L}$ underestimated the sparse $\mathrm{NO}_{3}$ concentrations measured in July and August 2001 by $10-30 \mathrm{mg} / \mathrm{L}$. Well 1N/6E-31C1 (5E) is in the northeast hydrogeologic unit (fig. 1) and is perforated in modellayers 1 and 2. The simulated model-layer 1 chemographs increased by about $3 \mathrm{mg} / \mathrm{L}$ after the start of the artificial recharge program, whereas the measured $\mathrm{NO}_{3}$ concentrations increased about $20 \mathrm{mg} / \mathrm{L}$ starting in early 1999 (fig. 33F). These results indicate that the artificial recharge program had a minor effect on the measured $\mathrm{NO}_{3}$ concentrations in the east and northeast hydrogeologic units.

In general, the simulated results using a source concentration of $220 \mathrm{mg} / \mathrm{L}$ underestimate the peak measured $\mathrm{NO}_{3}$ concentrations and using a source concentration of $350 \mathrm{mg} / \mathrm{L}$ overestimate the peak measured $\mathrm{NO}_{3}$ concentrations (fig. 33). These results suggest that the source concentration is between 220 and $350 \mathrm{mg} / \mathrm{L}$. For subsequent sensitivity analyses and predictive simulations, a source concentration of $350 \mathrm{mg} / \mathrm{L}$ was assumed. 


\section{Sensitivity Analysis}

Sensitivity analysis is a procedure that evaluates the model sensitivity to variations in the input parameters. The procedure involves keeping all input parameters constant except for the one being analyzed. Simulated hydraulic heads and $\mathrm{NO}_{3}$ concentrations from the calibrated 1995-2001 transient-state model (referred to as the base case) and the same model using the varied parameter are compared to analyze the model sensitivity to varied parameter values.

The model's sensitivity to flow parameters such as hydraulic conductivity $(K)$, specific yield $\left(S_{y}\right)$ specific storage $\left(S_{S}\right)$, hydraulic characteristic $(F 1-7)$, and general-head-boundary conductance $(G H B)$ was tested (table 9). When testing the sensitivity to variations in $K$, the values for all three layers were changed \pm 50 percent in order to maintain the vertical distribution of pumping used in the base case. The horizontal-to-vertical anisotropy ratio was maintained at 100:1. Model-layer 1 specific-yield values of 0.5 and 0.05 were tested for the west, midwest, and combined east (mideast, northeast, and east) hydrogeologic units individually ( $S_{y w}, S_{y m w}$ and $S_{y e}$ in table 9 ). The specific storage values for model layers 2 and 3 were increased and decreased by an order of magnitude individually ( $S_{S 2}$ and $S_{S 3}$ in table 9). All hydraulic characteristic values (faults) were increased and decreased by an order of magnitude individually. The conductance value of the general-head-boundary was increased and decreased by an order of magnitude. Note that in the previous section, two simulations were made using source $\mathrm{NO}_{3}$ concentrations of 220 and $350 \mathrm{mg} / \mathrm{L}$ and the results discussed; this may also interpreted as a type of sensitivity analysis.

Table 9 shows the variation in root-mean-square error (RMSE) between simulated year-2000 hydraulic heads and measured year-2000 water levels for each sensitivity analysis by hydrogeologic unit (west, midwest, mideast, and a combination of northeast and east) and the total RMSE for the entire model domain. Under some cases the RMSE decreased between the base case and sensitivity simulation indicating a better model fit; however, the sensitivity simulations only addressed the period 1995-2001, a period of waterlevel recovery. If the flow parameter that resulted in an improved RMSE were used to simulate the period of predevelopment or 1956-94, this change may result in a worse model fit for this period.

Overall, the calibrated 1995-2001 transient ground-water flow model was most sensitive to changes in the specific yield of model-layer 1; this sensitivity led to the implementation of three separate specific-yield zones and two sets (pre and post-waterlevel rise) of specific-yield values. Therefore, if the models are to be used for predictive purposes it is important that the appropriate set of specific-yield values are used. Specifically, if the water levels are declining into the middle aquifer then the lower specific-yield values should be used and if the water levels are rising into the upper aquifer then the higher specific-yield values should be used.

Decreasing the specific yield of the midwest hydrogeologic unit $\left(S_{y m w}\right)$ from the base-case value of 0.3 to 0.05 had the greatest effect on the total RMSE (table 9). Decreasing the specific yield of the west hydrogeologic unit $\left(S_{y w}\right)$ from 0.28 to 0.05 had the greatest effect on the RMSE of the west hydrogeologic unit (table 9). Decreasing the specific yield of the midwest hydrogeologic unit $\left(S_{y m w}\right)$ from 0.3 to 0.05 had the greatest effect on the RMSE of the midwest hydrogeologic unit (table 9). Decreasing the specific yield of the combined east hydrogeologic unit $\left(S_{y e}\right)$ from 0.3 to 0.05 had the greatest effect on the RMSE of the mideast hydrogeologic unit (table 9). Decreasing the specific yield of the combined east hydrogeologic units $\left(S_{y e}\right)$ from 0.3 to 0.05 had the greatest effect on the RMSE of the combination of the east and northeast hydrogeologic units (table 9). Although the calibrated 1995-2001 transient ground-water flow model was insensitive to changes in fault hydraulic characteristic and general-head-boundary conductance values, the predevelopment results were sensitive to changes in these parameters. 
Table 9. The variation in root-mean-square error (RMSE) between simulated year-2000 hydraulic heads and measured year-2000 water levels for each sensitivity analysis by hydrogeologic unit [west, midwest, mideast, and total east (east and northeast)] and the total RMSE for the entire model domain

[K, hydraulic conductivity; $S_{\mathrm{yw}}$, specific yield, west hydrogeologic unit; $\mathrm{S}_{\mathrm{ymw}}$, specific yield, midwest hydrogeologic unit; $\mathrm{S}_{\mathrm{ye}}$, specific yield, total east hydrogeologic unit; $\mathrm{S}_{\mathrm{s} 2}$, specific storage, layer 2; $\mathrm{S}_{\mathrm{s} 3}$, specific storage, layer 3; F1—F7, fault 1-7 hydraulic characteristic; GHB, general-head boundary conductance; RMSE, root-mean-square error]

\begin{tabular}{|c|c|c|c|c|c|}
\hline & $\begin{array}{l}\text { West } \\
\text { RMSE }\end{array}$ & $\begin{array}{l}\text { Midwest } \\
\text { RMSE }\end{array}$ & $\begin{array}{l}\text { Mideast } \\
\text { RMSE }\end{array}$ & $\begin{array}{c}\text { Total east } \\
\text { RMSE }\end{array}$ & $\begin{array}{l}\text { Total } \\
\text { RMSE }\end{array}$ \\
\hline Base case & 25.03 & 63.71 & 35.32 & 27.33 & 42.10 \\
\hline$K+50$ percent & 24.54 & 67.10 & 30.25 & 27.19 & 42.69 \\
\hline $\mathrm{K}-50$ percent & 26.50 & 58.45 & 50.44 & 27.68 & 43.42 \\
\hline $\mathrm{S}_{\mathrm{yw}}=0.5$ & 22.04 & 62.10 & 34.82 & 27.33 & 40.65 \\
\hline$S_{y_{w}}=0.05$ & 68.92 & 65.26 & 35.56 & 27.33 & 58.14 \\
\hline$S_{y m w}=0.5$ & 25.28 & 83.43 & 30.54 & 27.33 & 50.57 \\
\hline$S_{\mathrm{ymw}}=0.05$ & 23.44 & 369.79 & 107.71 & 27.33 & 206.40 \\
\hline$S_{y e}=0.5$ & 25.13 & 60.26 & 29.98 & 28.24 & 39.79 \\
\hline$S_{\mathrm{ye}}=0.05$ & 24.31 & 145.94 & 341.16 & 18.04 & 175.28 \\
\hline $\mathrm{S}_{\mathrm{s} 2} \times 10$ & 24.67 & 59.59 & 32.25 & 27.52 & 39.69 \\
\hline $\mathrm{S}_{\mathrm{s} 2} \times 0.1$ & 25.07 & 64.76 & 36.60 & 27.33 & 42.79 \\
\hline $\mathrm{S}_{\mathrm{s} 3} \times 10$ & 25.13 & 62.94 & 33.96 & 27.39 & 41.55 \\
\hline $\mathrm{S}_{\mathrm{s} 3} \times 0.1$ & 25.03 & 63.82 & 35.50 & 27.33 & 42.18 \\
\hline $\mathrm{F} 1 \times 10$ & 22.52 & 63.71 & 35.52 & 27.33 & 41.56 \\
\hline $\mathrm{F} 1 \times 0.1$ & 25.91 & 63.71 & 35.32 & 27.33 & 42.29 \\
\hline $\mathrm{F} 2 \times 10$ & 25.36 & 63.34 & 36.64 & 27.33 & 42.24 \\
\hline $\mathrm{F} 2 \times 0.1$ & 24.97 & 63.70 & 34.93 & 27.33 & 42.01 \\
\hline $\mathrm{F} 3 \times 10$ & 24.94 & 73.39 & 25.41 & 27.33 & 45.07 \\
\hline $\mathrm{F} 3 \times 0.1$ & 25.14 & 59.69 & 44.74 & 27.33 & 42.27 \\
\hline $\mathrm{F} 4 \times 10$ & 25.08 & 62.63 & 31.33 & 27.29 & 40.96 \\
\hline $\mathrm{F} 4 \times 0.1$ & 25.03 & 63.90 & 36.04 & 27.35 & 42.31 \\
\hline $\mathrm{F} 5 \times 10$ & 25.03 & 63.76 & 35.33 & 29.29 & 42.28 \\
\hline $\mathrm{F} 5 \times 0.1$ & 25.03 & 63.72 & 35.32 & 27.01 & 42.07 \\
\hline $\mathrm{F} 6 \times 10$ & 25.03 & 63.70 & 35.24 & 27.44 & 42.08 \\
\hline $\mathrm{F} 6 \times 0.1$ & 25.03 & 63.71 & 35.32 & 27.29 & 42.09 \\
\hline $\mathrm{F} 7 \times 10$ & 25.03 & 63.71 & 35.32 & 24.50 & 41.88 \\
\hline F7× 0.1 & 25.03 & 63.71 & 35.32 & 27.75 & 42.13 \\
\hline $\mathrm{GHB} \times 10$ & 25.03 & 63.72 & 35.32 & 27.41 & 42.11 \\
\hline $\mathrm{GHB} \times 0.1$ & 25.03 & 63.71 & 35.32 & 27.33 & 42.10 \\
\hline
\end{tabular}


The model's sensitivity to solute-transport parameters also was tested; the dispersivity $(\alpha)$ values (longitudinal, horizontal transverse, and vertical transverse) for the three model layers were increased and decreased by an order of magnitude, by layer. Higher $\alpha$ values should result in a breakthrough curve that has a lower peak concentration and a wider base, and lower $\alpha$ values should result in a higher peak concentration that has a narrower base. In both cases, the total mass of solute would remain constant as dispersivity only affects the amount of spreading.

The results for selected wells in the west, midwest, and mideast hydrogeologic units are presented in figure 34 . Note that the tails of the breakthrough curves were not simulated because only seven years were simulated; therefore, the conservation of mass could not be verified.

Well 1S/5E-3D1 (8W) is located in the west hydrogeologic unit and perforated in model layers 1 and 2. In general, for well 3D1 the simulated modellayer 1 and $2 \mathrm{NO}_{3}$ concentrations were insensitive to variations in $\alpha$ (fig. 34A).

Well 1N/5E-36K2 (9E) is located in the midwest hydrogeologic unit and perforated in model-layers 1 and 2 . In general, the simulated $\mathrm{NO}_{3}$ concentrations for model layer 1 of well $36 \mathrm{~K} 2$ were sensitive to variations in $\alpha$ and had a lower peak concentration associated with the higher value and a higher peak concentration associated with the lower $\alpha$ value (fig. 34B). The simulated $\mathrm{NO}_{3}$ concentrations for model layer 2 were sensitive to variations in $\alpha$ and had a higher peak concentration associated with the higher value and a lower peak concentration associated with the lower value. The model-layer 2 sensitivity may seem contrary to the model-layer 1 results; however, the simulation period was probably not long enough for the model-layer 2 base-case and lower $\alpha$ simulations to reach the peak concentration.

Well 1N/5E-36M5 (16E) is located in the midwest hydrogeologic unit and perforated in modellayers 2 and 3 . The simulated $\mathrm{NO}_{3}$ concentrations for model-layer 2 were sensitive only to increases in $\alpha$ and had a higher peak concentration associated with the higher $\alpha$ value (fig. 34C); these results are similar to the model-layer 2 results for well 36K2 (9E). The simulated $\mathrm{NO}_{3}$ concentrations for model layer 3 were insensitive to variations in $\alpha$.

Well 1N/5E-36H2 (18E) is located in the mideast hydrogeologic unit and perforated in model-layers 1 and 2 . The simulated $\mathrm{NO}_{3}$ concentrations for modellayer 1 were sensitive to variations in $\alpha$ and had a higher peak concentration associated with the higher $\alpha$ value and a lower peak concentration associated with the lower $\alpha$ value (fig. 34D). These results seem contrary to the model-layer 1 results at well $36 \mathrm{~K} 2$; however, the simulation period was probably not long enough for the base-case and lower $\alpha$ simulations to reach the peak concentration. The simulated $\mathrm{NO}_{3}$ concentrations for model-layer 2 were somewhat sensitive to variations in $\alpha$ and had a higher peak concentration associated with the higher $\alpha$ value and a lower peak concentration associated with the lower $\alpha$ value, similar to the model-layer 2 results for wells 36K2 (9E) and 36M5 (16E).

\section{PROPOSED CONJUNCTIVE-USE PROJECT}

HDWD has proposed a conjunctive-use project in the west hydrogeologic unit that includes a five acre recharge pond (site 3 , see figs. 1,22) and one extraction well near the pond. The proposed project will be implemented in conjunction with the existing recharge ponds (sites 6 and 7). The approximate location of site 3 was based on a consultant's report that evaluated potential recharge sites within the HDWD boundary (Bechtel, 1994). The effect of the proposed conjunctive-use project was evaluated using the calibrated ground-water flow and solute transport models developed for this study. 


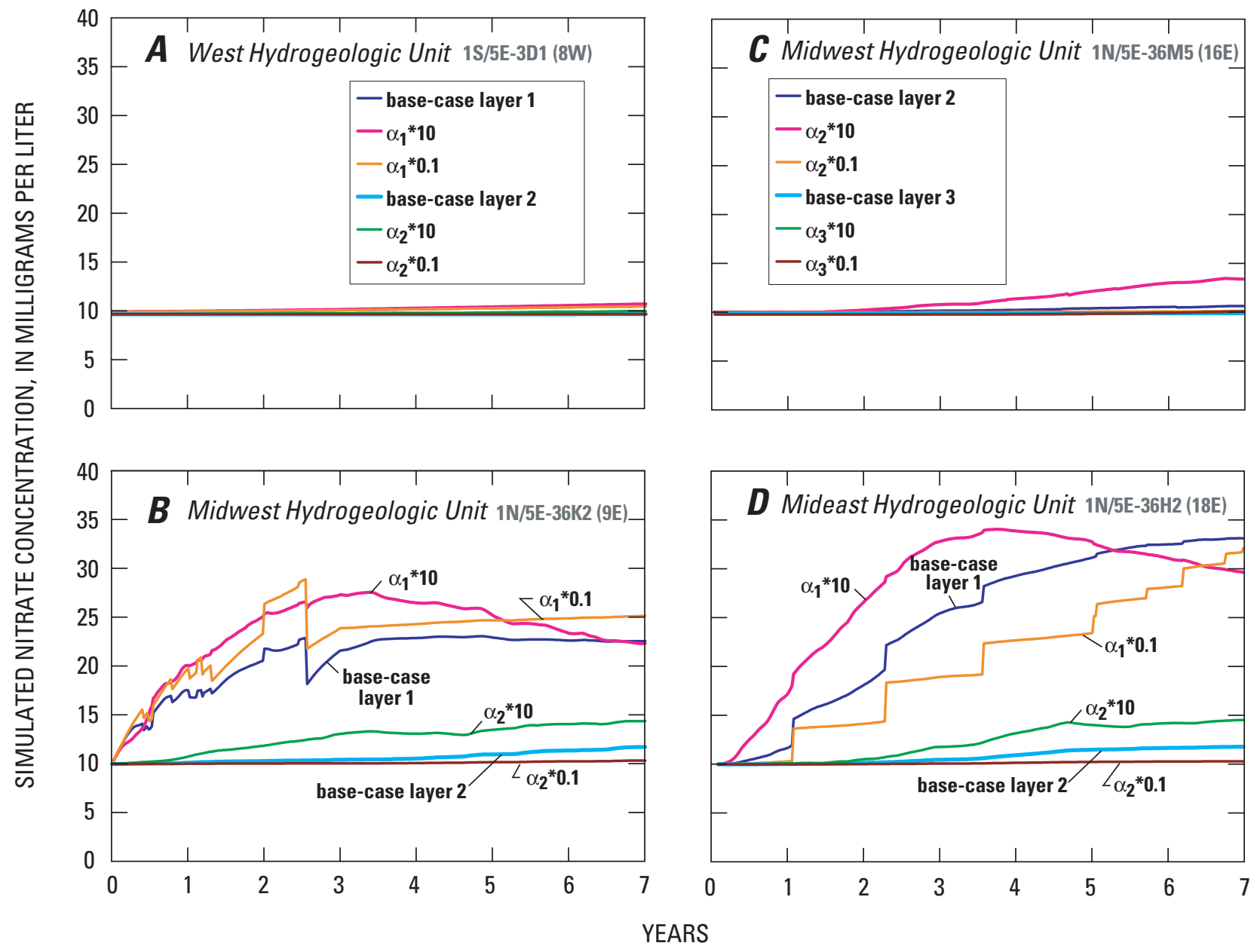

Figure 34. Simulated nitrate concentrations from the calibrated transient-state solute-transport model showing sensitivity to dispersivity: (A) $1 \mathrm{~S} / 5 \mathrm{E}-3 \mathrm{D} 1$ (8W), (B) 1N/5E-36K2 (9E), (C) 1N/5E-36M5 (16E), and (D) 1N/5E-36H2 (18E), Warren ground-water basin, San Bernardino County, California. 
The simulated hydraulic heads and $\mathrm{NO}_{3}$ concentrations at the end of December 2001 were used as initial conditions for the management scenario. The model was used to simulate 10 years of pumping and artificial recharge using monthly stress periods. The total simulated recharge rate for sites 3,6 , and 7 was 7,100 acre-ft/yr, with site 3 receiving 3,300 acre-ft/yr and the balance being recharged at sites 6 and 7 (evenly divided between the two sites) (Marty Stockstell, Hi-Desert Water District, written commun., 2002). The new pumping well was assumed to be located immediately south of the recharge pond and perforated in model layers 1 and 2 (400-900 ft below land surface) with a total pumping rate of $800 \mathrm{gal} / \mathrm{min}$ (Marty Stockstell, Hi-Desert Water District, written commun., 2002). It was assumed that the monthly 2001 pumping rates were held constant in the existing HDWD wells, with the exception of wells 1N/5E36M4 (12E), 1N/5E-36M5 (16E), and 1N/5E-36M6 (17E), which were assumed to be used in conjunction with a planned $\mathrm{NO}_{3}$ removal facility. The pumping rates for these wells were set equal to 1,200 gpm, 300 gpm, 400 gpm, respectively (Marty Stockstell, HiDesert Water District, written commun., 2002). In addition, it was assumed that the 1993 land-use pattern is representative of future conditions; therefore, the 1996-2001 septic recharge rates and septic recharge $\mathrm{NO}_{3}$ concentrations were held constant. It was also assumed that the source $\mathrm{NO}_{3}$ concentration of commercial, residential, and multi-family septage was $350 \mathrm{mg} / \mathrm{L}$.

The proposed artificial recharge program resulted in an increase in simulated hydraulic heads of about $60 \mathrm{ft}$ in the west hydrogeologic unit in the vicinity of site 3 after 10 years. This simulated hydraulic-head rise was assumed to entrain $\mathrm{NO}_{3}$ that was moving through the unsaturated zone, similar to the 1995-97 measured water-level rise. The quantity and concentration of the captured unsaturated zone water was estimated using the land-use relation developed for the 1995-97 water-level rise; however, it was assumed that the water-level rise entrained the $\mathrm{NO}_{3}$ in one year. In addition, 100 percent of the estimated $\mathrm{NO}_{3}$ concentrations of septage and irrigation return flow were used in the solute-transport model. Recall that 50 percent of the estimated $\mathrm{NO}_{3}$ concentrations of septage and irrigation return flow were used in the transient calibration; therefore, using 100 percent will yield conservative estimates of $\mathrm{NO}_{3}$ concentrations.
The recharge flux resulting from the water-level rise and the 1996-2001 septic-recharge and irrigationreturn-flow fluxes, and associated $\mathrm{NO}_{3}$ concentrations, were used in the first year (stress periods 1-12) of the management scenario simulation. The 1996-2001 septic-recharge and irrigation-return-flow fluxes, and associated $\mathrm{NO}_{3}$ concentrations, were used in years 2-10 (stress periods 13-120) of the simulation.

Figure 35 shows contours of simulated change in model-layer 1 hydraulic head from December 2001 to December 2011 resulting from the proposed conjunctive-use project. Note that in figure 35 , negative changes in water levels indicate a water-level rise and positive changes indicate a water-level decrease. In the west hydrogeologic unit, the recharge at site 3, the entrained septage, and the septage flux resulted in an increase in simulated hydraulic heads of $75 \mathrm{ft}$ near site 3 . In the midwest hydrogeologic unit, continued recharge at site 6 coupled with the increase in pumping from wells 1N/5E-36M4 (12E), 1N/5E-36M5 (16E), and $1 \mathrm{~N} / 5 \mathrm{E}-36 \mathrm{M} 6$ (17E) resulted in a simulated hydraulic-head decline of about $85 \mathrm{ft}$. In the mideast hydrogeologic unit, continued recharge at site 7 resulted in a simulated hydraulic-head rise of about $190 \mathrm{ft}$ near the recharge pond. The simulated hydraulic head in the mideast hydrogeologic unit was above landsurface elevation. In most of the east hydrogeologic unit, there was relatively no change in simulated hydraulic head. In the northeast hydrogeologic unit, the simulated hydraulic heads decreased by as much as $25 \mathrm{ft}$.

Note that any change in simulated hydraulic head will probably underestimate any actual waterlevel change because the specific-yield values used for the water-level recovery simulation (1995-2001) were not changed for the management scenario. For example, the simulated hydraulic-head decline in the midwest hydrogeologic unit was probably underestimated because water-levels declined into the middle aquifer (the lower part of model-layer 1) which is characterized by lower specific yield values. In addition, the simulated hydraulic-head rise beneath the recharge pond in the mideast hydrogeologic unit also was probably underestimated because the specific yield would be lower beneath the ponds (and to a lesser extent beneath any area experiencing recharge) because of a higher moisture content leading to less available pore space. Lower specific-yield values would result in greater water-level decline and (or) rise. 


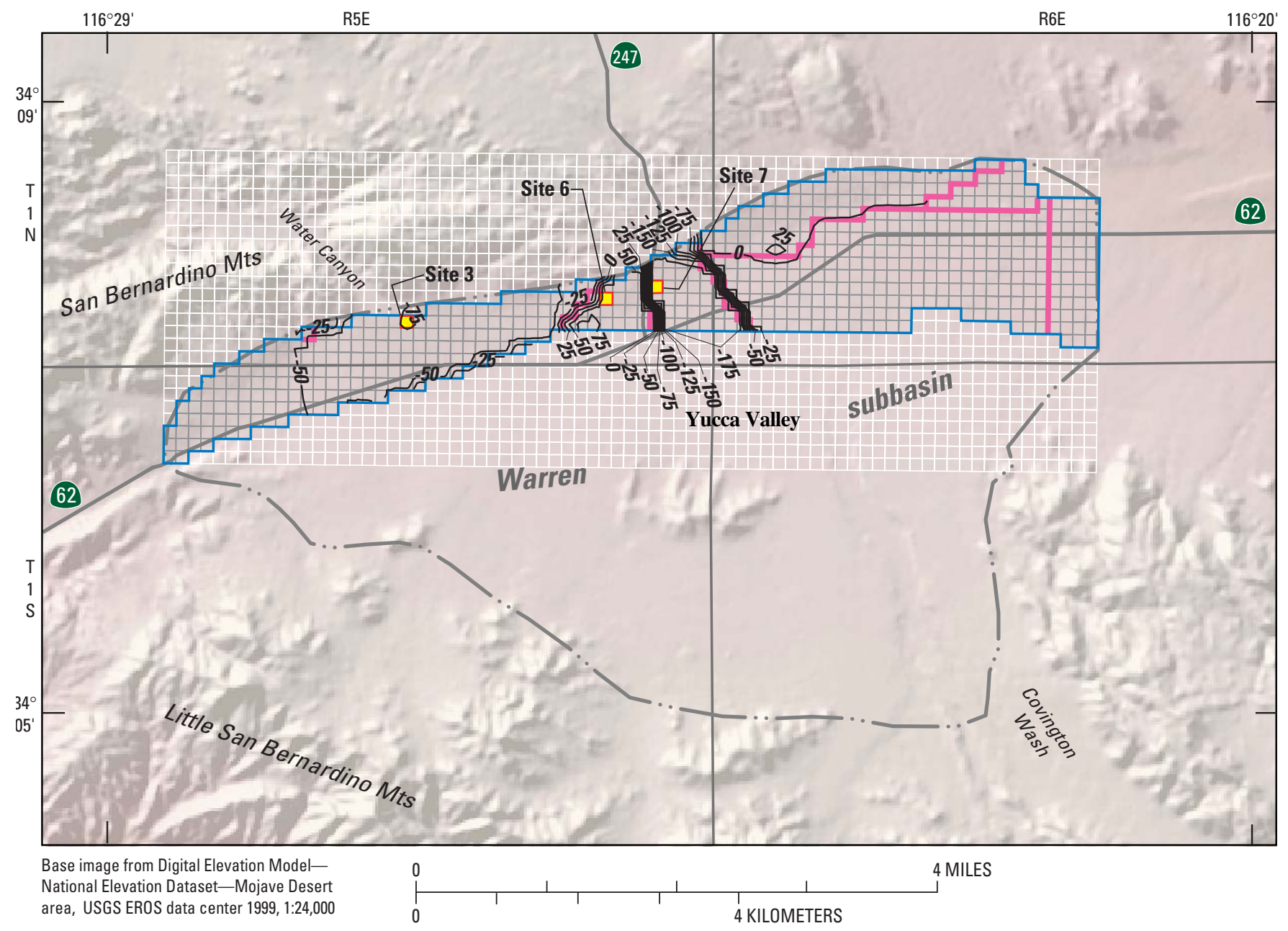

EXPLANATION
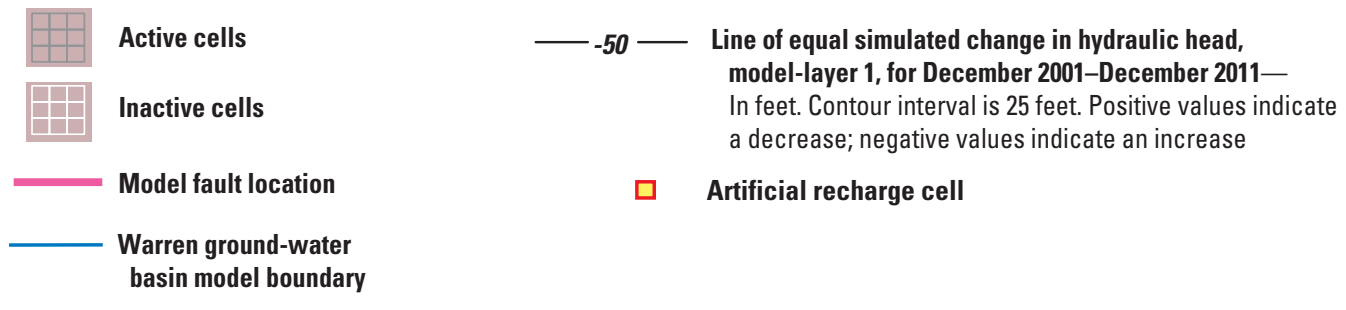

Figure 35. Contours of simulated change in model-layer 1 hydraulic head between December 2001 and December 2011 for the proposed conjunctive-use project, Warren ground-water basin, San Bernardino County, California. 
The change in simulated model-layer $1 \mathrm{NO}_{3}$ concentrations between December 2011 and December 2001 are shown in figure $36 A$ and the simulated December 2011 model-layer $1 \mathrm{NO}_{3}$ concentrations are shown in figure $36 \mathrm{~B}$. In the west hydrogeologic unit, in the immediate vicinity of recharge site 3 , there was no change in $\mathrm{NO}_{3}$ concentrations because the area surrounding site 3 in 1993 was undeveloped (fig. 2) and, therefore, had a low moisture content and $\mathrm{NO}_{3}$ concentration. However in the western and eastern parts of the west hydrogeologic unit, the simulated $\mathrm{NO}_{3}$ concentrations increased about $30-35 \mathrm{mg} / \mathrm{L}$ (fig. 36A) to a maximum concentration of $50-55 \mathrm{mg} / \mathrm{L}$ (above MCL of $44 \mathrm{mg} / \mathrm{L}$ ) (fig. 36B). In the midwest hydrogeologic unit, in the immediate vicinity of recharge site 6 , there was little change in simulated $\mathrm{NO}_{3}$ concentrations. However in the southern part of the midwest hydrogeologic unit, near well $1 \mathrm{~N} / 5 \mathrm{E}-$ $36 \mathrm{~K} 2$ (9E), the simulated $\mathrm{NO}_{3}$ concentration decreased about $15 \mathrm{mg} / \mathrm{L}$ from 55 to $40 \mathrm{mg} / \mathrm{L}$. In the mideast hydrogeologic unit, in the immediate vicinity of recharge site 7, there was little change in simulated $\mathrm{NO}_{3}$ concentrations. However in the southeastern part of the mideast hydrogeologic unit, the simulated $\mathrm{NO}_{3}$ concentrations increased as much as $50 \mathrm{mg} / \mathrm{L}$ to a maximum concentration of $115 \mathrm{mg} / \mathrm{L}$. In the east hydrogeologic unit, the simulated $\mathrm{NO}_{3}$ concentrations stayed relatively constant with the exception of the eastern and western parts of the hydrogeologic unit where the simulated $\mathrm{NO}_{3}$ concentrations increased between $40-50 \mathrm{mg} / \mathrm{L}$ to a maximum of more than 70 $\mathrm{mg} / \mathrm{L}$ (fig. 36A, $\underline{B}$ ). In the northeast hydrogeologic unit, the simulated $\mathrm{NO}_{3}$ concentrations increased $5-10 \mathrm{mg} / \mathrm{L}$. The increase in simulated $\mathrm{NO}_{3}$ concentrations in the mideast and east hydrogeologic units is related to commercial land use (fig. 2).

\section{LIMITATIONS}

When applied carefully, a numerical model can be useful for projecting aquifer responses to various changes in aquifer stresses; however, a model is a highly idealized approximation of the actual system and is based on average and estimated conditions. Perhaps the biggest limitation is the failure of an idealized, lumped-parameter model to capture a complex hydrogeologic setting. The capability of the model to reliably project aquifer responses is also related to the accuracy of the input data used in the model calibration and is inversely related to the magnitude of the proposed changes in the stresses being applied to the model as well as to the length of the simulation horizon.

In this study, the model was calibrated using manual trial-and-error techniques. Owing to the complexity and unknowns of the system being represented, it is worth noting that model construction and calibration (formal or not) result in a non-unique product and that model predictions are subject of potentially large errors (Konikow and Bredehoeft, 1992). Automated approaches could be used in subsequent studies to more formally characterize uncertainties in the parameters and perhaps improve the fit of the model to calibration data (Yeh, 1986).

The upper and middle aquifers were modeled as a single aquifer (model layer 1) because of limitations in MOC3D. Specifically, MOC3D cannot simulate the rewetting of the upper aquifer that resulted from the artificial recharge program (Konikow and others, 1996). In order to more accurately simulate the groundwater system, the upper aquifer should be simulated explicitly.

In order to simulate the measured water-level decline that occurred from the late 1940s through 1994 relatively low specific-yield values were required. However, in order to simulate the measured water-level recovery that occurred after 1995 higher specific-yield values were required; this was explained by the rising water levels entering the coarser-grained upper aquifer. The simulation of the management scenario indicated a water-level decline in the midwest hydrogeologic unit and a water-level rise in the mideast hydrogeologic unit; without a priori knowledge the appropriate specific-yield values cannot be used to simulate the simultaneous water-level declines and rises. 


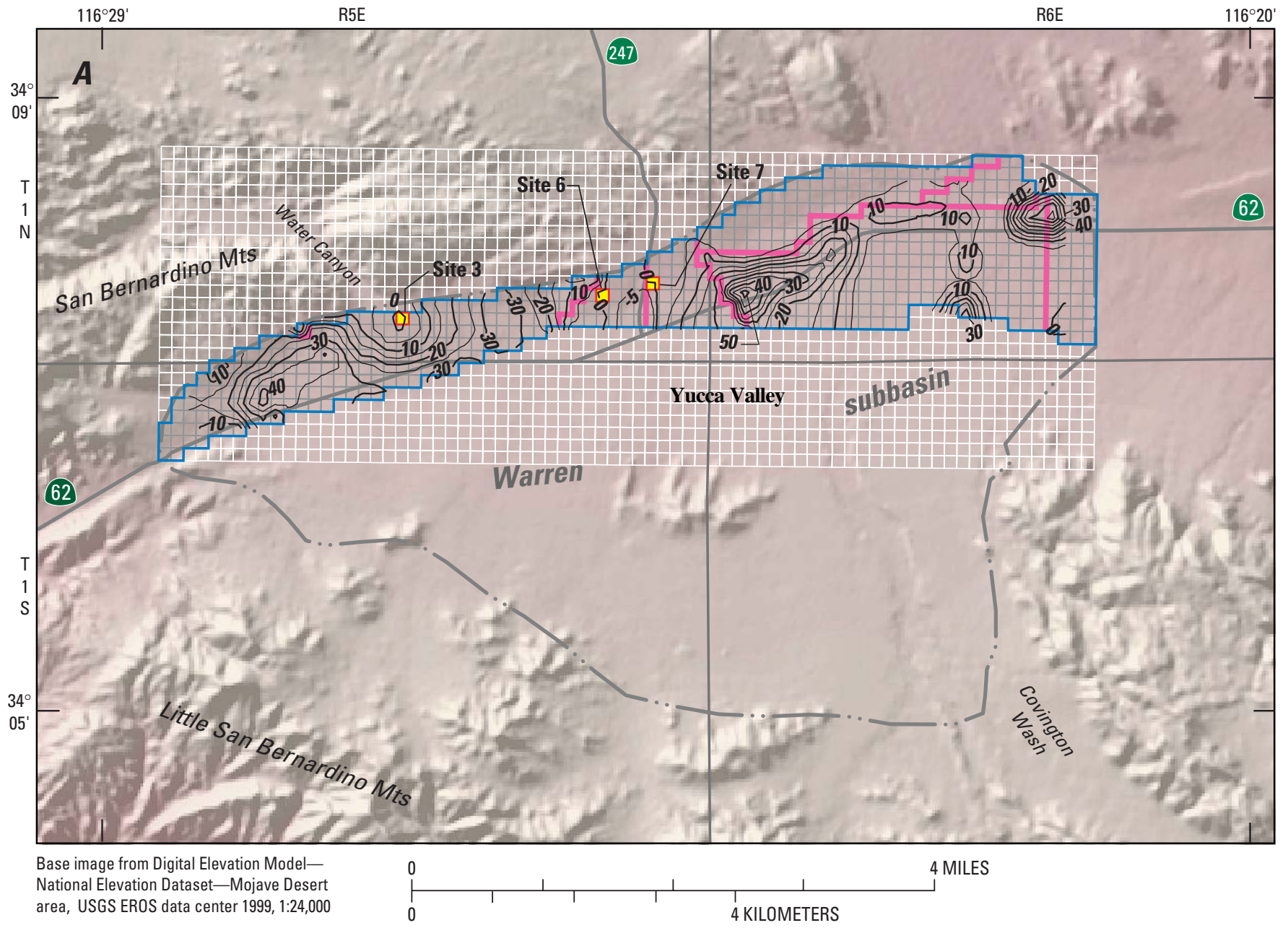

EXPLANATION
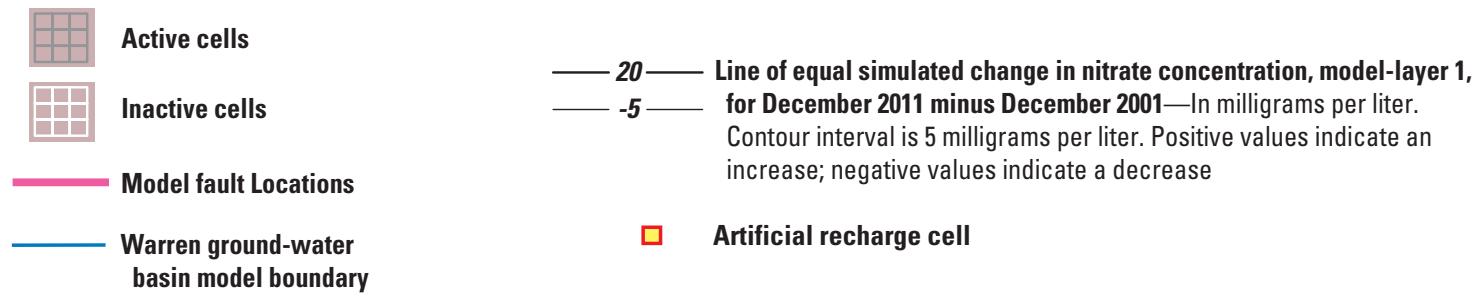

$\square \quad$ Artificial recharge cell

Figure 36. Contours of $(A)$ change in simulated nitrate concentrations between December 2001 and December 2011 conditions and $(B)$ simulated nitrate concentrations for December 2011 in model-layer 1 for the proposed conjunctive-use project, Warren ground-water basin, San Bernardino County, California. 


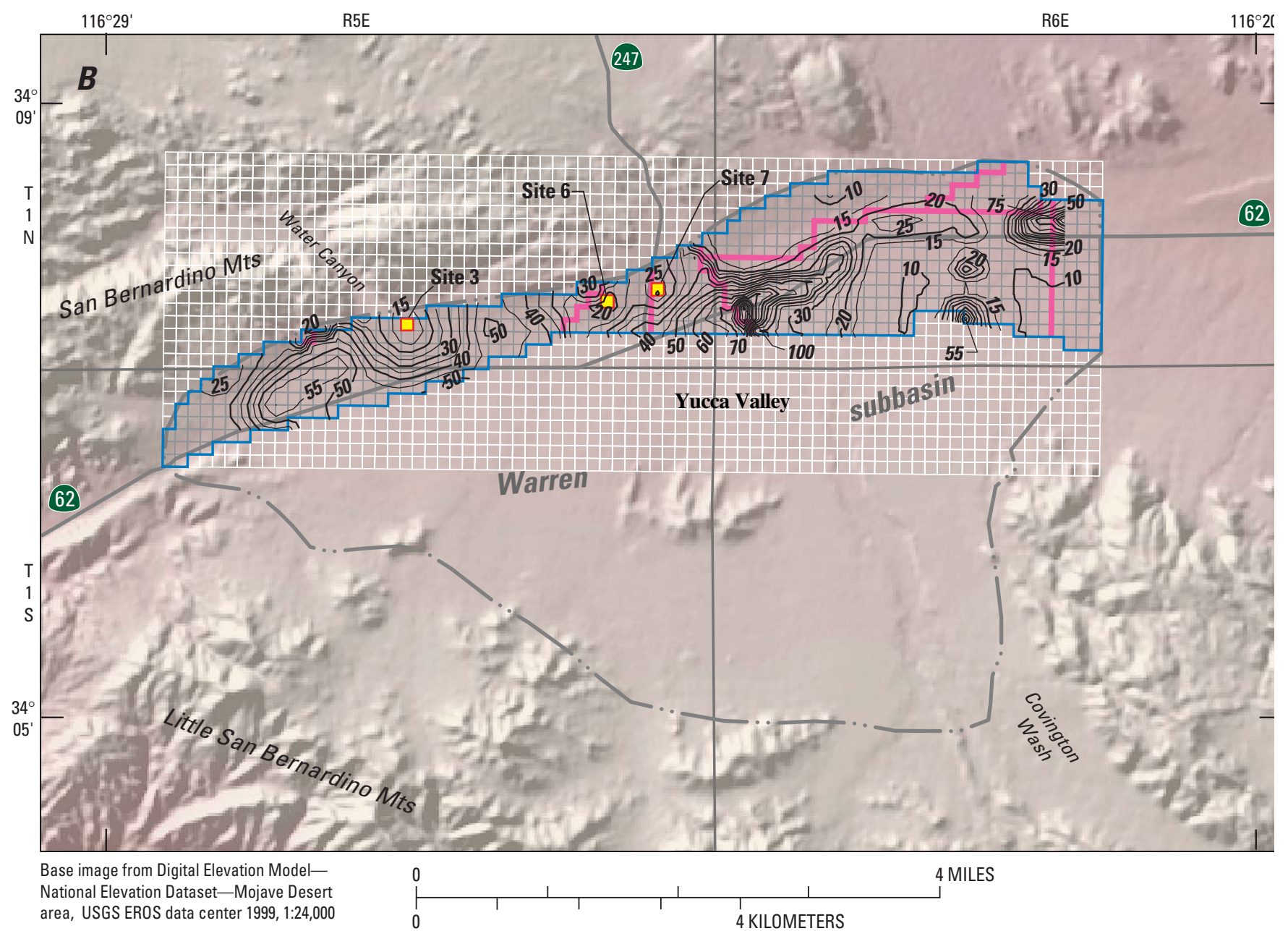

\section{EXPLANATION}

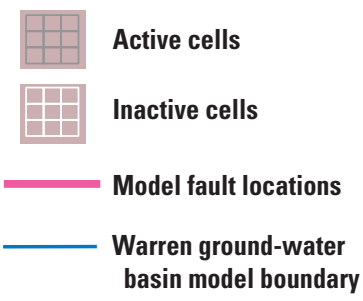
- 20 - Line of equal simulated nitrate concentration, model-layer $\mathbf{1}$,
_ 55 _ for December 2011_- In milligrams per liter. Contour interval is 5 milligrams per liter
$\square \quad$ Artificial recharge cell

Figure 36.-Continued. 
Simulated hydraulic-head responses to pumping show that faults strongly compartmentalize the groundwater flow system. It is probable that there are additional concealed faults crossing the study area that have not as yet been mapped in areas that are not being pumped. If additional pumping occurs in these areas, then these concealed faults may become apparent and may need to be incorporated in the model.

Accurate transient-state simulation [initial value problem (Bear, 1972)] requires the accurate simulation of the initial conditions. Most of the observed predevelopment water levels were measured in the upper and middle aquifers (model layer 1); therefore, the water levels in the lower (model layer 2) and deep (model layer 3) aquifers were not well defined.

\section{CONCLUSIONS}

From the late 1940s through 1994, water levels in the Warren subbasin declined as much as $300 \mathrm{ft}$ due to ground-water extraction. In response, the Hi-Desert Water District (HDWD) instituted an artificial recharge program in 1995 to replenish the ground-water basin using imported California State Water Project (SWP) water. The artificial recharge program resulted in water-level recovery of about $250 \mathrm{ft}$ between 1995 and present; however, $\mathrm{NO}_{3}$ concentrations in some wells also increased from a background concentration of $10 \mathrm{mg} / \mathrm{L}$ to more than the USEPA maximum contaminant level (MCL) of $44 \mathrm{mg} / \mathrm{L}(10 \mathrm{mg} / \mathrm{L}$ as nitrogen).

The objectives of this study were to: (1) evaluate the sources of the high-nitrate concentrations that occurred after the start of the artificial recharge program, (2) develop a ground-water-flow and solutetransport model to better understand the source and transport of nitrates in the aquifer system, and (3) utilize the calibrated models to evaluate the possible effects of a proposed conjunctive-use project. This was accomplished by collecting water-level and waterquality data for the subbasin and assessing any changes that have occurred since artificial recharge began. These data were used to constrain the ground-water flow and solute-transport models.

Data collected for this study indicate that the areal extent of the water-bearing deposits is much smaller than that of the subbasin and these water- bearing deposits are referred to as the Warren groundwater basin. Faults separate the ground-water basin into five hydrogeologic units; the west, the midwest, the mideast, the east, and the northeast hydrogeologic units.

The geohydrologic framework of the Warren subbasin was defined by summarizing previously published research, mapping the surficial geology of the subbasin, and by collecting geologic and hydrologic data from existing production and monitoring wells. Using available lithologic and geophysical logs, the ground-water system was subdivided vertically into four aquifers; the upper, middle, lower, and deep aquifers. Geologic mapping and water-level data indicate that several faults cross the Warren subbasin and have either juxtaposed preTertiary basement complex against unconsolidated alluvial deposits or have displaced preferential flow paths in unconsolidated alluvial deposits. This juxtaposition and displacement, along with cementation, compaction, and extreme deformation of the water-bearing deposits adjacent to faults can create low-permeability zones that can act as barriers to ground-water flow, thereby compartmentalizing the ground-water flow system.

Sources of recharge to the basin include natural mountain-front recharge and septic-tank effluent (septage), irrigation return flow from the golf course and other irrigated fields, and imported SWP water using recharge ponds. Previous investigators reported that the natural recharge rate is probably less than $200 \mathrm{acre}-\mathrm{ft} / \mathrm{yr}$. The quantity and distribution of recharge from septic tanks and irrigation return flows were estimated from land-use maps (available for 1952-53, 1965, 1977, and 1993). The total potential recharge rate in acre-feet per year for each land-use map was 711 (1952-53, assuming the construction of the golf course), 915 (1965), 1,212 (1977), and 1,688 (1993). The quantity of imported SWP recharged into two recharge ponds was about 24,300 acre-ft between February 1995 to the end of December 2001.

Natural discharge exits the basin through the Yucca Barrier located at the east end of the basin. Under steady-state conditions, inflow must equal outflow; therefore, the steady-state outflow is probably less than $200 \mathrm{acre}-\mathrm{ft} / \mathrm{yr}$. The first public water-supply well was drilled in Yucca Valley in 1949. However, significant ground-water development did not start 
until 1956, when an irrigation well was drilled in the west hydrogeologic unit to provide water for a 105 -acre golf course. Presently, there are 18 production wells in the Warren ground-water basin; in December 2001, nine public-supply wells yielded a total volume of 2,600 acre-ft of water. The total pumpage from 1956 to 2001 was about 80,000 acre-ft.

Published ground-water data for 1958, 1969, 1994, and 1998 were used to describe ground-water levels and movement in the study area. Long-term hydrographs indicate a water-level decline of about 300 $\mathrm{ft}$ from the late-1940s to 1994 in the midwest hydrogeologic unit. By 2000, almost five years after the start of the artificial recharge program, water levels had risen by as much as $250 \mathrm{ft}$ in the midwest hydrogeologic unit near site 6 and $220 \mathrm{ft}$ in the mideast hydrogeologic unit near site 7 .

Prior to the start of the artificial recharge program, $\mathrm{NO}_{3}$ concentrations ranged from 2.9 to $26 \mathrm{mg} / \mathrm{L}$. In 1998, three years after the start of the artificial recharge program, the $\mathrm{NO}_{3}$ concentrations increased to as high as $110 \mathrm{mg} / \mathrm{L}$ in the midwest and mideast hydrogeologic units where the recharge ponds were located. The highest $\mathrm{NO}_{3}$ concentrations were in wells perforated in the upper and middle aquifers.

Water-quality data analyses indicate that septage was the primary source of the high- $\mathrm{NO}_{3}$ concentrations measured in Warren ground-water basin wells. Waterquality and stable-isotope data, collected after the start of the artificial recharge program, indicate that mixing had occurred between artifically recharged imported water and native ground water, with the highest recorded $\mathrm{NO}_{3}$ concentrations in the midwest and mideast hydrogeologic units. In general, the timing of the increase in measured $\mathrm{NO}_{3}$ concentrations in samples from wells in the midwest hydrogeologic unit was directly related to the well's distance from recharge site 6 , indicating that the increase in $\mathrm{NO}_{3}$ concentrations is related to the artificial recharge program. Nitrate-to-chloride and nitrogen-isotope data, as well as analyses for caffeine and selected human pharmaceutical products, indicated that septage was the source of the measured increase in $\mathrm{NO}_{3}$ concentrations in the midwest and mideast hydrogeologic units.

The rapid rise in water levels resulting from the artificial recharge program entrained the large volume of septage that was stored in the unsaturated zone, resulting in a rapid increase in $\mathrm{NO}_{3}$ concentrations. This is shown by the increase in the $\mathrm{NO}_{3}$ concentrations in ground water after the start of the artificial recharge program in 1995. The largest increase in $\mathrm{NO}_{3}$ concentrations occurred in the midwest and mideast hydrogeologic units, which had the greatest increase in water levels. A simple mixingcell model showed that the measured increase in $\mathrm{NO}_{3}$ concentrations could be explained by the entrainment of septage stored in the unsaturated zone by rising water levels.

A ground-water flow and solute-transport model were developed for the Warren subbasin for the period 1956-2001. The ground-water flow model is MODFLOW based and the solute-transport model is MOC3D based. To simulate predevelopment conditions (no stresses), ground-water flow and solute transport were simulated for 10,000 years to allow the flow and concentration fields to equilibrate to specified initial and boundary conditions and these results were used as initial conditions for the 1956-2001 simulations. The models were calibrated to water-level and $\mathrm{NO}_{3}$-concentration data collected between 1956-2001 using a trial-and-error approach. In order to better match the measured data, low fault hydraulic characteristic values were used. In addition, it was necessary to divide the specific yield for model-layer 1 into three homogeneous zones. Separate sets of specific-yield values were needed to simulate the measured water level. The first set was used to simulate the drawdown period 1956-94 and had specific-yield values as low as 0.13 . The second set was used to simulate the water-level recovery period 1995-2001 and had specific-yield values as high as 0.3 . The entrainment of unsaturated-zone septage was simulated as recharge with an associated $\mathrm{NO}_{3}$ concentration. The volume of recharge was a function of the measured water-level rise between 1994 and 98 and the moisture content of the unsaturated zone. The $\mathrm{NO}_{3}$ concentration was a weighted function of the overlying land use.

The model calibration indicated that the natural recharge rate is about 83 acre-ft/yr. Natural discharge from the ground-water basin is outflow at the Yucca Barrier and results from the model developed for this study indicated that the outflow rate averaged about $85 \mathrm{acre}-\mathrm{ft} / \mathrm{yr}$ with a predevelopment outflow of about $86 \mathrm{acre}-\mathrm{ft} / \mathrm{yr}$. Note that under true steady-state conditions the natural recharge should equal the natural discharge; the small difference between the simulated natural recharge and discharge indicates that the model 
had not yet reached steady-state conditions after 10,000 years of simulated ground-water flow. The simulated hydraulic-head and $\mathrm{NO}_{3}$-concentration results are in good agreement with the measured data. The model results further support the conceptual model of rising water levels, resulting from the artificial recharge program, entraining the septage stored in the unsaturated zone thereby causing the increase in $\mathrm{NO}_{3}$ concentrations. The model results indicate that the artificial recharge program had a minor effect on the measured $\mathrm{NO}_{3}$ concentrations in the east and northeast hydrogeologic units. The model results also indicate that a majority of the artificially-recharged water in the midwest and the mideast hydrogeologic units remains in those units.

Sensitivity analyses of the models to variations in hydraulic (hydraulic conductivity, specific yield, specific storage, fault hydraulic characteristic, and general-head boundary conductance) and solutetransport (longitudinal, horizontal transverse, and vertical transverse dispersivity) parameters indicate the ground-water flow model is most sensitive to variations in model-layer 1 specific-yield values; particularly in the midwest and mideast hydrogeologic units. The solute-transport model is most sensitive to variations in model-layer 1 dispersivity values; particularly in the midwest and mideast hydrogeologic units.

The models were used to simulate the possible effects of a planned conjunctive use project. Specifically, the project includes the construction of a new recharge pond and a new extraction well in the west hydrogeologic unit. In addition, three existing production wells pump at a rate such that the water could be treated in a $\mathrm{NO}_{3}$-removal facility. Model results for this management scenario indicate that recharge at site 3 increases simulated hydraulic heads by more than $50 \mathrm{ft}$ throughout most of the west hydrogeologic unit; however, the rise in simulated hydraulic heads results in a $30 \mathrm{mg} / \mathrm{L}$ increase in simulated $\mathrm{NO}_{3}$ concentrations to $50-55 \mathrm{mg} / \mathrm{L}$ in December 2011 (above the MCL of $44 \mathrm{mg} / \mathrm{L}$ ) in the western and eastern parts of the hydrogeologic unit. In the midwest hydrogeologic unit, the pumping for $\mathrm{NO}_{3}$ removal decreases simulated hydraulic heads by more than $80 \mathrm{ft}$; however, the combination of the artificial recharge program and pumping decreases the simulated $\mathrm{NO}_{3}$ concentrations to below the MCL in most of the hydrogeologic unit. In the mideast hydrogeologic unit, the artificial recharge program, coupled with a lack of pumping, increases simulated hydraulic heads more than $190 \mathrm{ft}$ to above land-surface altitude indicating that a decrease in artificial recharge at site 7 or an increase in pumping within the mideast hydrogeologic unit are required to prevent waterlogging. In addition, in the southeastern part of the mideast hydrogeologic unit, the simulated $\mathrm{NO}_{3}$ concentrations increase to $115 \mathrm{mg} / \mathrm{L}$ (above the MCL of $44 \mathrm{mg} / \mathrm{L}$ ). In the east hydrogeologic unit, there is relatively no change in simulated hydraulic head; however, there is an increase in simulated $\mathrm{NO}_{3}$ concentrations of $40-50 \mathrm{mg} / \mathrm{L}$ in the western and eastern parts of the hydrogeologic unit. The increases in simulated $\mathrm{NO}_{3}$ concentrations in the mideast and east hydrogeologic units are related to commercial land-use. In the northeast hydrogeologic unit, the simulated hydraulic heads decrease by as much as $25 \mathrm{ft}$ with a 5-10 mg/L increase in simulated $\mathrm{NO}_{3}$ concentrations.

\section{REFERENCES}

Barber, L.B., Brown, G.K., Kennedy, K.R., Leenheer, J.A., Noyes, T.I., Rostad, C.E., and Thorn, K.A., 1997, Conjunctive use of water resources: aquifer storage and recovery, in Kendall, D.W., ed., Proceedings of the AWRA Symposium, Conjunctive Use of Water Resources: Aquifer Storage and Recovery, American Water Resources Association 33rd National Meeting, Long Beach, California, October 19-23, 1997: American Water Resources Association, Herndon, Virginia, TPS-97-2, p. 261-272.

Bear, Jacob, 1972, Dynamics of fluids in porous media: New York, Dover, $764 \mathrm{p}$.

Bear, Jacob, 1979, Hydraulics of groundwater: New York, McGraw-Hill, 569 p.

Bear, Jacob, and Verruijt, Arnold, 1987, Modeling groundwater flow and pollution: Boston, D. Reidel, $414 \mathrm{p}$.

Bechtel Corporation, 1994, Hydrogeological investigation for the siting and design of ground-water recharge basins at sites 6 and 7 in Yucca Valley, California: San Francisco, [about 250] p.

Bouwer, Herman, 1978, Groundwater hydrology: New York, McGraw-Hill, $480 \mathrm{p}$.

Burnett, R.D., and Frind, E.O., 1987, Simulation of contaminant transport in three dimensions, 2. Dimensionality effects: Water Resources Research, v. 23 , no. 4 , p. 695-705. 
California Irrigation Management Information System, 2002, California ETo zones map: California Department of Water Resources data available on the World Wide Web, accessed April 29, 2002, at URL http://www.cimis.water.ca.gov/.

Craig, Harmon, 1961, Isotopic variations in meteoric waters: Science, v. 133, p. 1702-1703.

Davis, S. N., and Bentley, H. W., 1982, Dating groundwater, a short review, in Currie, L. A., ed., Nuclear and chemical dating techniques: interpreting the environmental record; 179th meeting of the American Chemical Society, Houston, Texas, March 24-25, 1980: Amer. Chem. Soc. Sympos. Series no. 176, p.187-222.

Densmore, J. N., and Böhlke, J.K., 2000, Use of nitrogen isotopes to determine sources of nitrate contamination in two desert basins in California, in Reichard, E.G., and others, eds., Interdisciplinary perspectives on drinking water risk assessment and management: International Association of Hydrologic Sciences Publication 260, p. 63-73.

Dibblee, T.W., Jr., 1967, Geologic map of the Joshua Tree Quadrangle, San Bernardino and Riverside counties, California: U.S. Geological Survey Miscellaneous Geologic Investigations Map I-516.

Eckenfelder, W.W., Jr., 1980, Principles of water quality management: Boston, CBI Publishing Company, Inc., $717 \mathrm{p}$.

Fournier, R.O., and Thompson, J.M., 1980, The recharge area for the Coso, California, geothermal system deduced from $\delta \mathrm{D}$ and $\delta{ }^{18} \mathrm{O}$ in thermal and nonthermal waters in the region: U.S. Geological Survey Open-File Report 80-454, 27 p.

Freeze, R.A., and Cherry, J.A., 1979, Groundwater: Englewood Cliffs, N.J., Prentice-Hall, 604 p.

Gelhar, L.W., Welty, Claire, and Rehfeldt, K.R., 1992, A critical review of data on field-scale dispersion in aquifers: Water Resources Research, v. 28, no. 7 , p. 1955-1974.

Gonfiantini, Roberto, 1978, Standards for stable isotope measurements in natural compounds: Nature, v. 271, p. 534-536.

Gormly, J.R., and Spalding, R.F., 1979, Sources and concentrations of nitrate-nitrogen in ground water of the Central Platte region, Nebraska: Ground Water, v. 17, no. 3, p. 291-301.

Harbaugh, A.W., and McDonald, M.G., 1996, User's documentation for MODFLOW-96, an update to the U.S. Geological Survey modular finite-difference ground-water flow model: U.S. Geological Survey Open-File Report 96-485, 56 p.

Harding Lawson Associates, 1984, Electrical resistivity and gravity investigations for ground-water resources Warren Valley area San Bernardino County, California: Novato, Calif., 51 p., 10 pl.
Harkin, J.M., Chesters, Gordon, and Alhajjar, B.J., 1990, Indicators of chemical pollution from septic systems: Ground Water, v. 28, no. 4, p. 559-568.

Hart, E.W., Bryant, W.R., and Treiman, J.A., 1993, Surface faulting associated with the June 1992 Landers earthquake, California: California Geology, v. 16, p. 10-16.

Hem, J.D., 1992, Study and interpretation of the chemical characteristics of natural water ( $3 \mathrm{~d}$ ed): U.S. Geological Survey Water Supply Paper 2254, 263 p., 3 pl.

Heaton, T.H.E., 1986, Isotopic studies of nitrogen pollution in the hydrosphere and atmosphere: a review: Chemical Geology, v. 59, p. 87-102.

Hopson, R.F., 1998, Quaternary geology and neotectonics of the Pinto Mountain Fault, Mojave Desert, Southern California: California Geology, v. 51, no. 6, p. 3-13.

Hornberger, G.Z., Konikow, L.F., and Harte, P.T., 2002, Simulating solute transport across horizontal-flow barriers using the MODFLOW ground-water transport process: U.S. Geological Survey Open-File Report 02-52, 28 p.

Hsieh, P.A., and Freckleton, J.R., 1993, Documentation of a computer program to simulate horizontal-flow barriers using the U.S. Geological Survey's modular threedimensional finite-difference ground-water flow model: U.S. Geological Survey Open-File Report 92-477, 32 p.

Huff, J.A., Clark, D.A., and Martin, Peter, 2003, Lithologic and ground-water data for monitoring sites in the Mojave River and Morongo ground-water basins, San Bernardino County, California, 1992-1998: U.S. Geological Survey Open-File Report 02-354, 416 p.

Izbicki, J.A., Martin, Peter, and Michel, R.L., 1995, Source, movement and age of groundwater in the upper part of the Mojave River basin, California, U.S.A., in Adar, E.M., and Leibundgut, Christian, eds., Application of tracers in arid zone hydrology: International Association of Hydrological Sciences, no. 232, p. $43-56$.

Jennings, C.W., compiler, 1994, Fault activity map of California and adjacent areas: California Department of Conservation, Division of Mines and Geology, Geologic Data Map Series No. 6, scale 1:750,000.

Kendall, Carol, and Aravena, Ramon, 2000, Nitrate Isotopes in Groundwater Systems, in Environmental Tracers in Subsurface Hydrology, Cook, P.G. and Herczeg, A.L., eds., Kluwer Academic Publisher, Boston, Mass., chap. 9, p. 261-297.

Koebig and Koebig, 1966, Study of local water supply and need for supplemental water for Lucerne Valley and Yucca-Joshua Valley: San Diego, Calif., 11 p.

Konikow, L.F., and Bredehoeft, J.D., 1992, Validation of geohydrological models: part 1: Advances in Water Resources, v 1. 15, no. 1, p. 75-83. 
Konikow, L.F., Goode, D.J., and Hornberger, G.Z., 1996, A three-dimensional method-of-characteristics solutetransport model (MOC3D): U.S. Geological Survey Water-Resources Investigations Report 96-4267, 87 p.

Kreitler, C.W., 1975, Determining the source of nitrate in ground water by nitrogen isotope studies: Bureau of Economic Geology, University of Texas at Austin, Report of Investigations No. 83, 57 p.

Leenheer, J.A., Rostad, C.E., Barber, L.B., Schroeder, R.A., Anders, Robert, Davisson, M.L., 2001, Nature and chlorine reactivity of organic constituents from reclaimed water in groundwater, Los Angeles County, California: Environ. Sci. Technol., v. 35, no. 19, p. 3869-3876.

Lewis, R.E., 1972, Ground-water resources of the Yucca Valley-Joshua Tree area, San Bernardino County, California: U.S. Geological Survey Open-File Report, $51 \mathrm{p}$.

Linsley, R.K, and Franzini, J.B., 1979, Water-resources engineering ( $3 \mathrm{~d}$ ed.): New York, McGraw-Hill, 716 p.

Lohman, S.W., 1979, Ground-water hydraulics: U.S. Geological Survey Professional Paper 708, 70 p.

Martin, Peter, 1980, Evaluation of ground-water quality in the Cortaro area, Arizona: Tucson, University of Arizona, unpublished M.S. thesis, 99 p.

McDonald, M.G., and Harbaugh, A.W., 1988, A modular three dimensional finite-difference ground-water flow model: U.S. Geological Survey Techniques of WaterResources Investigations, book 6, chap. A1, 576 p.

Mendez, G.O., and Christensen, A.H., 1997, Regional watertable (1996) and water-level changes in the Mojave River, the Morongo, and the Fort Irwin ground-water basins, San Bernardino County, California: U.S. Geological Survey Water-Resources Investigations Report 97-4160, 34 p., map in pocket.

Michel, R.L, 1976, Tritium inventories of the world oceans and their implications: Nature, v. 263, p. 103-106.

Roberts, C.W., Jachens, R.C., Katzenstein, A.M., Smith, G.A., and Johnson, R.U., 2002, Gravity map and data of the eastern half of the Big Bear Lake, 100,000 scale quadrangle, California and analysis of the depths of several basins: U.S. Geological Survey Open-File Report 02-353, accessed October 4, 2002, at URL http://geopubs.wr.usgs.gov/open-file/of02-353/.

Scheidegger, A.E., 1961, General theory of dispersion in porous media: Jour. Geophys. Research, v. 66, no. 10, p. 3273-3278.
Schroeder, R.A., Martin, Peter, and Böhlke, J.K., 1993, Chemical, isotopic, and microbiological evidence for denitrification during transport of domestic wastewater through a thick unsaturated zone in the Mojave Desert: U.S. Geological Survey Open-File Report 93-414, 10 p.

Seiler, R.L, Zaugg, S.D., Thomas, J.M., and Howcroft, D.L., 1999, Caffeine and pharmaceuticals as indicators of waste water contamination of wells: Ground Water, v. 37, no. 3, p. 405-410.

Smith, G.A., and Pimentel, M.I., 2000, Regional water-table (1998) and ground-water-level changes in the Mojave River and the Morongo ground-water basins, San Bernardino County, California: U.S. Geological Survey Water-Resources Investigations Report 00-4090, 107 p., map in pocket.

Thrailkill, John, Wiseman, R.F., and Scanlon, B.R., 1985, Investigation of pollution in a karst aquifer utilizing optical brightener: Kentucky Water Resources Research Institute Report 158, Lexington, 39 p.

Trayler, C.R., and Koczot, K.M., 1995, Regional water-table (1994) and water-level changes in the Morongo Basin, San Bernardino County, California: U.S. Geological Survey Water-Resources Investigations Report 954209, scale 1:125,000, 1 sheet.

Treiman, J.A., 1992, Eureka Peak and Burnt Mountain faults, two "new" faults in Yucca Valley, San Bernardino County, California, in Ebersold, B.B., ed., Landers Earthquake of June 28, 1992, San Bernardino County, California Field Trip Guidebook: Southern California section of the Association of Engineering Geologists, p. 19-22.

Umari, A.M.J., Martin, Peter, Schroeder, R.A., Duell, Jr., L.F.W., and Fay, R.G., 1995, Potential for ground-water contamination from movement of wastewater through the unsaturated zone, Upper Mojave River Basin, California: U.S. Geological Survey Water-Resources Investigations Report 93-4137, 83 p.

U.S. Environmental Protection Agency, 2002, Drinking water standards: current drinking water standards available on the World Wide Web, accessed Sept. 3, 2002, at URL http://www.epa.gov/safewater/mcl.html.

Yeh, W. W-G., 1986, Review of parameter identification procedures in groundwater hydrology: the inverse problem: Water Resources Research, v. 22, no. 1, p. 95-108. 
TABLE 4 
Table 4. Nitrate concentrations, in milligrams per liter as $\mathrm{NO}_{3}$ (nitrate), in ground water from wells in Warren ground-water basin, San Bernardino County, California, 1964-2001

[All data were provided by Hi-Desert Water District, except where noted; *, samples collected and analyzed by U.S. Geological Survey; —, no data]

\begin{tabular}{|c|c|c|c|c|c|c|c|c|c|c|c|c|}
\hline Date & $\begin{array}{c}\text { 1N/5E- } \\
36 \mathrm{~L} 1 \\
\text { (7E) }\end{array}$ & $\begin{array}{c}1 \mathrm{~N} / 5 \mathrm{E}- \\
36 \mathrm{~K} 3 \\
(14 \mathrm{E})\end{array}$ & $\begin{array}{c}1 \mathrm{~N} / 5 \mathrm{E}- \\
36 \mathrm{M} 4 \\
(12 \mathrm{E})\end{array}$ & $\begin{array}{c}1 \mathrm{~N} / 6 \mathrm{E}- \\
31 \mathrm{C1} \\
\text { (5E) }\end{array}$ & $\begin{array}{c}1 \mathrm{~N} / 5 \mathrm{E}- \\
36 \mathrm{~K} 2 \\
(9 \mathrm{E})\end{array}$ & $\begin{array}{c}\text { 1N/5E- } \\
36 \mathrm{M5} \\
\text { (16E) }\end{array}$ & $\begin{array}{c}\text { 1N/5E- } \\
36 \mathrm{M} 6 \\
(17 \mathrm{E})\end{array}$ & $\begin{array}{c}1 \mathrm{~N} / 5 \mathrm{E}- \\
36 \mathrm{H} 2 \\
(18 \mathrm{E})\end{array}$ & $\begin{array}{l}1 \mathrm{~N} / 5 \mathrm{E} \\
34 \mathrm{~K} 2 \\
(2 \mathrm{~W})\end{array}$ & $\begin{array}{c}\text { 1N/5E- } \\
35 P 1 \\
(3 W)\end{array}$ & $\begin{array}{c}\text { 1N/5E- } \\
3401 \\
(6 W)\end{array}$ & $\begin{array}{c}\text { 1S/5E- } \\
\text { 3D1 } \\
(8 W)\end{array}$ \\
\hline [Hydrogeologic units] & Midwest & Mideast & Midwest & Northeast & Midwest & Midwest & Midwest & Mideast & West & West & West & West \\
\hline $11 / 12 / 64$ & - & - & - & - & - & - & - & - & - & 8.0 & - & - \\
\hline $6 / 23 / 71$ & - & - & - & 10.0 & - & - & - & - & - & - & - & - \\
\hline $3 / 14 / 72$ & - & - & - & 8.0 & - & - & - & - & - & - & - & - \\
\hline $7 / 6 / 72$ & - & - & - & 8.0 & - & - & - & - & - & - & - & - \\
\hline 7/19/72 & - & - & - & 9.0 & - & - & - & - & - & - & - & - \\
\hline $8 / 8 / 72$ & - & - & - & - & - & - & - & - & - & 15.0 & - & - \\
\hline $12 / 19 / 72$ & 8.0 & - & - & - & - & - & - & - & - & - & - & - \\
\hline $10 / 17 / 73$ & 9.0 & - & - & 12.0 & - & - & - & - & - & - & - & - \\
\hline 4/10/74 & 9.0 & - & - & 11.0 & - & - & - & - & - & - & - & - \\
\hline $5 / 9 / 75$ & - & - & - & - & 9.0 & - & - & - & - & - & - & - \\
\hline $6 / 24 / 81$ & - & - & - & - & $* 11.5$ & - & - & - & - & - & - & - \\
\hline $8 / 4 / 82$ & - & - & - & - & $* 12.8$ & - & - & - & - & - & - & - \\
\hline $8 / 11 / 83$ & - & - & - & - & $* 12.8$ & - & - & - & - & - & - & - \\
\hline $6 / 19 / 84$ & - & - & - & - & $* 12.8$ & - & - & - & - & - & - & - \\
\hline $6 / 27 / 85$ & - & - & - & - & $* 13.7$ & - & - & - & - & - & - & - \\
\hline $10 / 2 / 85$ & - & - & - & - & - & - & - & - & - & - & - & - \\
\hline $3 / 5 / 86$ & - & - & 13.0 & - & - & - & - & - & - & - & - & - \\
\hline $6 / 11 / 86$ & - & - & 8.0 & - & - & - & - & - & - & - & - & - \\
\hline $9 / 22 / 86$ & - & - & - & - & $* 13.3$ & - & - & - & - & - & - & - \\
\hline $6 / 24 / 87$ & - & - & - & - & $* 10.6$ & - & - & - & - & - & - & - \\
\hline 9/9/87 & 11.0 & - & 13.0 & 14.0 & - & - & - & - & - & - & - & - \\
\hline 9/30/87 & - & - & - & - & - & - & - & - & - & - & - & - \\
\hline $11 / 20 / 88$ & - & - & - & - & - & - & - & - & - & - & - & - \\
\hline $5 / 17 / 89$ & - & - & - & $* 15.5$ & $* 12.0$ & - & - & - & - & - & - & - \\
\hline $10 / 13 / 89$ & - & - & - & - & - & - & - & - & - & - & - & - \\
\hline $10 / 25 / 89$ & 11.0 & - & 13.0 & 12.0 & 11.0 & - & - & - & - & - & - & - \\
\hline $3 / 6 / 90$ & - & 9.0 & - & - & - & - & - & - & - & - & - & - \\
\hline $5 / 18 / 90$ & - & - & - & - & - & 10.0 & - & - & - & - & - & - \\
\hline 7/3/90 & - & - & - & - & - & - & - & 9.0 & - & - & - & - \\
\hline $9 / 26 / 90$ & - & 9.0 & - & - & - & 10.0 & 13.0 & - & - & - & - & - \\
\hline $10 / 10 / 90$ & 8.0 & - & - & - & - & - & - & - & - & - & - & - \\
\hline 1/30/91 & - & - & 12.0 & - & 11.0 & 10.0 & - & - & - & - & - & - \\
\hline 2/13/91 & - & 9.0 & - & - & - & - & - & 9.0 & - & - & - & - \\
\hline $6 / 20 / 91$ & - & - & - & - & $* 12.8$ & - & - & - & - & - & - & - \\
\hline 9/4/91 & - & - & - & - & - & - & - & - & - & 15.5 & - & - \\
\hline $9 / 23 / 92$ & 11.4 & - & - & - & - & - & - & - & - & - & - & 8.1 \\
\hline 9/30/92 & - & - & - & 13.4 & - & - & - & - & - & - & - & - \\
\hline $11 / 2 / 92$ & - & - & - & - & - & - & - & - & - & - & 10.1 & - \\
\hline $12 / 3 / 92$ & - & - & - & - & $* 11.1$ & - & - & - & - & - & - & - \\
\hline $3 / 25 / 93$ & - & - & - & - & - & - & - & - & - & - & - & - \\
\hline $5 / 18 / 93$ & - & - & - & $* 15.9$ & $* 9.7$ & - & - & - & - & - & - & - \\
\hline $8 / 11 / 93$ & - & - & - & - & - & - & - & - & - & - & - & - \\
\hline $1 / 9 / 94$ & - & - & 15.5 & - & - & - & - & - & - & - & - & - \\
\hline $1 / 17 / 94$ & - & - & - & - & - & - & - & - & 10.9 & - & - & - \\
\hline $1 / 24 / 94$ & - & 9.1 & - & - & 11.5 & - & - & 8.8 & - & - & - & - \\
\hline $1 / 25 / 94$ & - & - & - & - & *11.4 & - & - & - & - & - & - & - \\
\hline
\end{tabular}


Table 4. Nitrate concentrations, in milligrams per liter as $\mathrm{NO}_{3}$, in ground water from wells in Warren ground-water basin, San Bernardino County, California, 1964-2001-Continued

\begin{tabular}{|c|c|c|c|c|c|c|c|c|c|c|c|c|}
\hline $\begin{array}{c}1 \mathrm{~N} / 5 \mathrm{E}- \\
3402 \\
(9 \mathrm{~W})\end{array}$ & $\begin{array}{c}1 \mathrm{~N} / 5 \mathrm{E}- \\
34 \mathrm{P4} \\
(10 \mathrm{~W})\end{array}$ & $\begin{array}{c}1 \mathrm{~N} / 5 \mathrm{E}- \\
35 \mathrm{~K} 1 \\
(11 \mathrm{~W})\end{array}$ & $\begin{array}{l}\text { 1N/5E- } \\
34 \mathrm{~N} 1 \\
(5 \mathrm{~W})\end{array}$ & $\begin{array}{c}1 \mathrm{~N} / 6 \mathrm{E}- \\
29 \mathrm{~J} 3 \\
(11 \mathrm{E})\end{array}$ & $\begin{array}{c}1 \mathrm{~N} / 6 \mathrm{E}- \\
29 \mathrm{R} 3 \\
(13 \mathrm{E})\end{array}$ & $\begin{array}{c}\text { 1N/5E- } \\
36 G 1 \\
\text { (YV1-570) }\end{array}$ & $\begin{array}{c}\text { 1N/5E- } \\
36 G 2 \\
\text { (YV1-400) }\end{array}$ & $\begin{array}{c}\text { 1N/5E- } \\
36 G 3 \\
\text { (YV1-305) }\end{array}$ & $\begin{array}{c}\text { 1N/5E- } \\
36 G 4 \\
\text { (YV1-230) }\end{array}$ & $\begin{array}{c}\text { 1N/5E- } \\
36 \mathrm{M} 1 \\
\text { (YV2-570) }\end{array}$ & $\begin{array}{c}\text { 1N/5E- } \\
36 M 2 \\
\text { (YV2-390) }\end{array}$ & $\begin{array}{c}\text { 1N/5E- } \\
36 M 3 \\
\text { (YV2-300) }\end{array}$ \\
\hline West & West & West & West & Northeast & Northeast & Mideast & Mideast & Mideast & Mideast & Midwest & Midwest & Midwest \\
\hline- & - & - & - & - & - & - & - & - & - & - & - & - \\
\hline - & - & - & - & - & - & - & - & - & - & - & - & - \\
\hline- & - & - & - & - & - & - & - & - & - & - & - & - \\
\hline- & - & - & - & - & - & - & - & - & - & - & - & - \\
\hline - & - & - & - & - & - & - & - & - & - & - & - & - \\
\hline- & - & - & - & - & - & - & - & - & - & - & - & - \\
\hline- & - & - & - & - & - & - & - & - & - & - & - & - \\
\hline- & - & - & - & - & - & - & - & - & - & - & - & - \\
\hline- & - & - & - & - & - & - & - & - & - & - & - & - \\
\hline- & - & - & - & - & - & - & - & - & - & - & - & - \\
\hline- & - & - & - & - & - & - & - & - & - & - & - & - \\
\hline- & - & - & - & - & - & - & - & - & - & - & - & - \\
\hline- & - & - & - & - & - & - & - & - & - & - & - & - \\
\hline- & - & - & - & - & - & - & - & - & - & - & - & - \\
\hline- & - & - & - & - & - & - & - & - & - & - & - & - \\
\hline - & - & - & - & 20 & - & - & - & - & - & - & - & - \\
\hline- & - & - & - & - & - & - & - & - & - & - & - & - \\
\hline- & - & - & - & - & - & - & - & - & - & - & - & - \\
\hline- & - & - & - & - & - & - & - & - & - & - & - & - \\
\hline- & - & - & - & - & - & - & - & - & - & - & - & - \\
\hline- & - & - & - & - & - & - & - & - & - & - & - & - \\
\hline- & - & - & - & 56 & - & - & - & - & - & - & - & - \\
\hline - & - & - & - & 26 & - & - & - & - & - & - & - & - \\
\hline- & - & - & - & - & - & - & - & - & - & - & - & - \\
\hline- & - & - & - & - & $* 22.0$ & - & - & - & - & - & - & - \\
\hline- & - & - & - & - & - & - & - & - & - & - & - & - \\
\hline- & - & - & - & - & - & - & - & - & - & - & - & - \\
\hline- & - & - & - & - & - & - & - & - & - & - & - & - \\
\hline- & - & - & - & - & - & - & - & - & - & - & - & - \\
\hline- & - & - & - & - & - & - & - & - & - & - & - & - \\
\hline- & - & - & - & - & - & - & - & - & - & - & - & - \\
\hline- & - & - & - & - & - & - & - & - & - & - & - & - \\
\hline- & - & - & - & - & - & - & - & - & - & - & - & - \\
\hline- & - & - & - & - & - & - & - & - & - & - & - & - \\
\hline- & - & - & - & - & - & - & - & - & - & - & - & - \\
\hline- & 6.2 & - & 2.9 & - & - & - & - & - & - & - & - & - \\
\hline- & - & - & - & - & - & - & - & - & - & - & - & - \\
\hline- & - & - & - & - & - & - & - & - & - & - & - & - \\
\hline- & - & - & - & - & - & - & - & - & - & - & - & - \\
\hline 9.3 & - & - & - & - & - & - & - & - & - & - & - & - \\
\hline- & - & - & - & - & - & - & - & - & - & - & - & - \\
\hline- & - & 11.5 & - & - & - & - & - & - & - & - & - & - \\
\hline- & - & - & - & - & - & - & - & - & - & - & - & - \\
\hline- & - & - & - & - & - & - & - & - & - & - & - & - \\
\hline- & - & - & - & - & - & - & - & - & - & - & - & - \\
\hline- & - & - & - & - & - & $* 9.2$ & - & - & - & $* 8.8$ & - & - \\
\hline
\end{tabular}


Table 4. Nitrate concentrations, in milligrams per liter as $\mathrm{NO}_{3}$, in ground water from wells in Warren ground-water basin, San Bernardino County, California, 1964-2001-Continued

\begin{tabular}{|c|c|c|c|c|c|c|c|c|c|c|c|c|}
\hline Date & $\begin{array}{c}\text { 1N/5E- } \\
36 \mathrm{~L} 1 \\
\text { (7E) }\end{array}$ & $\begin{array}{c}1 N / 5 E- \\
36 K 3 \\
(14 E)\end{array}$ & $\begin{array}{c}1 \mathrm{~N} / 5 \mathrm{E}- \\
36 \mathrm{M} 4 \\
(12 \mathrm{E})\end{array}$ & $\begin{array}{c}1 \mathrm{~N} / 6 \mathrm{E}- \\
31 \mathrm{C1} \\
(5 \mathrm{E})\end{array}$ & $\begin{array}{c}1 \mathrm{~N} / 5 \mathrm{E}- \\
36 \mathrm{~K} 2 \\
(9 \mathrm{E})\end{array}$ & $\begin{array}{c}\text { 1N/5E- } \\
36 \mathrm{M} 5 \\
(16 E)\end{array}$ & $\begin{array}{l}\text { 1N/5E- } \\
36 \mathrm{M6} \\
\text { (17E) }\end{array}$ & $\begin{array}{c}\text { 1N/5E- } \\
36 \mathrm{H} 2 \\
(18 \mathrm{E})\end{array}$ & $\begin{array}{c}1 \mathrm{~N} / 5 \mathrm{E} \\
34 \mathrm{~K} 2 \\
(2 \mathrm{~W})\end{array}$ & $\begin{array}{c}\text { 1N/5E- } \\
35 P 1 \\
(3 W)\end{array}$ & $\begin{array}{c}1 N / 5 E- \\
3401 \\
(6 W)\end{array}$ & $\begin{array}{c}\text { 1S/5E- } \\
\text { 3D1 } \\
(8 W)\end{array}$ \\
\hline [Hydrogeologic units] & Midwest & Mideast & Midwest & Northeast & Midwest & Midwest & Midwest & Mideast & West & West & West & West \\
\hline $1 / 31 / 94$ & - & - & 14.5 & - & - & 10.7 & - & - & - & - & - & - \\
\hline 2/14/94 & - & - & - & - & - & - & 17.2 & - & - & - & - & - \\
\hline $1 / 12 / 95$ & - & - & - & - & - & - & - & - & - & - & - & - \\
\hline $1 / 13 / 95$ & - & - & - & - & - & - & - & - & - & - & - & - \\
\hline $1 / 16 / 95$ & 11.8 & 10.0 & - & - & 11.2 & 9.9 & 20.3 & - & - & - & - & - \\
\hline $4 / 4 / 95$ & - & - & - & - & - & - & - & - & - & - & - & - \\
\hline $5 / 12 / 95$ & - & - & - & - & $* 10.1$ & - & - & - & - & - & - & - \\
\hline 7/11/95 & 14.6 & 13.4 & 18.8 & - & 15.5 & - & 22.7 & - & - & 30.4 & - & - \\
\hline $10 / 17 / 95$ & - & - & - & - & - & - & - & - & - & - & - & - \\
\hline $10 / 19 / 95$ & - & - & - & 17.7 & - & - & - & - & - & 32.4 & - & 9.0 \\
\hline $1 / 24 / 96$ & 10.4 & 8.6 & 13.4 & - & 9.9 & 10.9 & 20.2 & - & - & 26.8 & 8.7 & - \\
\hline 4/11/96 & - & - & - & - & - & - & 20.7 & - & - & 32.2 & - & - \\
\hline $6 / 18 / 96$ & - & - & - & - & - & - & - & - & - & *33.2 & - & - \\
\hline 7/3/96 & - & - & 20.9 & - & 11.6 & - & - & - & - & 9.3 & - & - \\
\hline 7/5/96 & 14.0 & 9.4 & - & - & - & 12.9 & 24.7 & - & - & - & - & - \\
\hline 8/7/96 & - & - & - & - & - & - & - & - & - & - & - & - \\
\hline $10 / 9 / 96$ & 14.2 & - & - & - & - & - & 25.9 & - & - & 26.7 & - & - \\
\hline $12 / 17 / 96$ & - & - & - & - & - & - & - & - & - & - & - & - \\
\hline $12 / 18 / 96$ & - & - & - & - & - & - & - & - & - & - & - & - \\
\hline $12 / 19 / 96$ & - & - & - & - & - & - & - & - & - & - & - & - \\
\hline $1 / 16 / 97$ & 24.9 & 11.3 & 23.7 & - & 12.5 & 11.2 & 28.3 & 10.1 & 14.0 & 10.9 & - & - \\
\hline $3 / 31 / 97$ & - & - & - & $* 18.6$ & *15.9 & - & - & - & - & - & - & - \\
\hline 4/8/97 & - & - & - & - & - & - & - & - & - & 27.4 & - & - \\
\hline 7/11/97 & 22.2 & 10.6 & 24.3 & - & 20.5 & 10.6 & 32.8 & - & - & 26.2 & - & - \\
\hline 7/28/97 & - & - & - & - & - & - & - & - & - & - & - & - \\
\hline $8 / 26 / 97$ & - & - & - & - & - & - & - & - & - & - & - & - \\
\hline $8 / 27 / 97$ & - & - & - & - & - & - & - & - & - & - & - & - \\
\hline $10 / 21 / 97$ & - & - & - & - & - & - & - & - & - & - & - & - \\
\hline $10 / 22 / 97$ & - & - & - & - & - & - & 46.2 & - & - & - & - & - \\
\hline $10 / 24 / 97$ & - & - & - & - & - & - & 53.4 & - & - & - & - & - \\
\hline $10 / 27 / 97$ & - & - & - & - & - & 11.4 & - & - & - & - & - & - \\
\hline $11 / 5 / 97$ & 70.8 & - & 27.0 & - & - & - & - & - & - & - & - & - \\
\hline $11 / 10 / 97$ & 90.8 & - & - & - & - & - & - & - & - & - & - & - \\
\hline $11 / 12 / 97$ & - & - & 27.7 & - & - & - & - & - & - & - & - & - \\
\hline $11 / 17 / 97$ & 95.2 & 16.7 & 28.1 & - & 26.1 & 10.7 & 48.8 & 10.4 & - & - & - & - \\
\hline $11 / 24 / 97$ & 88.6 & 17.1 & - & 17.6 & 24.5 & 11.1 & 48.7 & 10.5 & - & - & - & - \\
\hline $12 / 1 / 97$ & 91.0 & 17.1 & - & 16.5 & 25.9 & 10.5 & 45.2 & 10.7 & - & - & - & - \\
\hline $12 / 8 / 97$ & 80.0 & 16.1 & - & 12.0 & 17.9 & 12.4 & 44.7 & 9.2 & - & - & - & - \\
\hline $12 / 15 / 97$ & 72.0 & 14.9 & - & 10.5 & 16.8 & 9.7 & 38.9 & 9.0 & - & - & - & - \\
\hline $12 / 22 / 97$ & 78.5 & 19.7 & - & 10.9 & 20.3 & 11.0 & 44.3 & 10.0 & - & - & - & - \\
\hline $12 / 29 / 97$ & 66.4 & 18.0 & - & 10.2 & 16.7 & 8.6 & 42.2 & 8.8 & - & - & - & - \\
\hline $1 / 5 / 98$ & 68.1 & 16.5 & - & 9.5 & 20.4 & 8.2 & 41.3 & 9.6 & - & - & - & - \\
\hline $1 / 12 / 98$ & 73.2 & 21.1 & - & 9.2 & 24.4 & 10.1 & 47.4 & 9.5 & - & - & - & - \\
\hline $1 / 19 / 98$ & 68.7 & 17.0 & - & 8.4 & 39.9 & 10.0 & 45.0 & 9.7 & - & 18.8 & - & - \\
\hline $1 / 26 / 98$ & 66.4 & 17.7 & - & 8.4 & 46.4 & 9.6 & 44.2 & 9.1 & - & - & - & - \\
\hline $1 / 28 / 98$ & - & - & - & - & 58.2 & - & - & - & - & - & - & - \\
\hline
\end{tabular}


Table 4. Nitrate concentrations, in milligrams per liter as $\mathrm{NO}_{3}$, in ground water from wells in Warren ground-water basin, San Bernardino County, California, 1964-2001—Continued

\begin{tabular}{|c|c|c|c|c|c|c|c|c|c|c|c|c|}
\hline $\begin{array}{c}1 N / 5 E- \\
3402 \\
(9 W)\end{array}$ & $\begin{array}{c}\text { 1N/5E- } \\
34 \mathrm{P4} \\
(10 \mathrm{~W})\end{array}$ & $\begin{array}{c}1 \mathrm{~N} / 5 \mathrm{E}- \\
35 \mathrm{~K} 1 \\
(11 \mathrm{~W})\end{array}$ & $\begin{array}{c}\text { 1N/5E- } \\
34 N 1 \\
(5 W)\end{array}$ & $\begin{array}{c}1 \mathrm{~N} / 6 \mathrm{E}- \\
29 \mathrm{J3} \\
(11 \mathrm{E})\end{array}$ & $\begin{array}{c}1 \mathrm{~N} / 6 \mathrm{E}- \\
29 \mathrm{R} 3 \\
(13 \mathrm{E})\end{array}$ & $\begin{array}{c}\text { 1N/5E- } \\
36 G 1 \\
\text { (YV1-570) }\end{array}$ & $\begin{array}{c}\text { 1N/5E- } \\
36 G 2 \\
\text { (YV1-400) }\end{array}$ & $\begin{array}{c}\text { 1N/5E- } \\
36 G 3 \\
\text { (YV1-305) }\end{array}$ & $\begin{array}{c}\text { 1N/5E- } \\
36 G 4 \\
\text { (YV1-230) }\end{array}$ & $\begin{array}{c}\text { 1N/5E- } \\
36 \mathrm{M} 1 \\
\text { (YV2-570) }\end{array}$ & $\begin{array}{c}\text { 1N/5E- } \\
36 M 2 \\
\text { (YV2-390) }\end{array}$ & $\begin{array}{c}\text { 1N/5E- } \\
36 \mathrm{M} 3 \\
\text { (YV2-300) }\end{array}$ \\
\hline West & West & West & West & Northeast & Northeast & Mideast & Mideast & Mideast & Mideast & Midwest & Midwest & Midwest \\
\hline- & - & - & - & - & - & - & - & - & - & - & - & - \\
\hline- & - & - & - & - & - & - & - & - & - & - & - & - \\
\hline- & - & - & - & - & - & $* 9.3$ & - & - & - & - & - & - \\
\hline- & - & - & - & - & - & - & $* 10.6$ & - & - & - & - & - \\
\hline- & - & - & - & - & - & - & - & - & - & - & - & - \\
\hline- & - & 30.7 & - & - & - & - & - & - & - & - & - & - \\
\hline- & - & - & - & - & - & - & - & - & - & - & - & - \\
\hline- & - & 28.3 & - & - & - & - & - & - & - & - & - & - \\
\hline- & $* 8.3$ & - & - & - & - & - & - & - & - & - & - & - \\
\hline- & - & - & - & - & - & - & - & - & - & - & - & - \\
\hline- & - & 19.6 & - & - & - & - & - & - & - & - & - & - \\
\hline 10.7 & - & 23.4 & - & - & - & - & - & - & - & - & - & - \\
\hline- & 8.0 & - & - & - & - & - & - & - & - & - & - & - \\
\hline- & - & - & - & - & - & - & - & - & - & - & - & - \\
\hline- & - & - & - & - & - & - & - & - & - & - & - & - \\
\hline$* 10.2$ & - & - & - & - & - & - & - & - & - & - & - & - \\
\hline- & - & 19.6 & - & - & - & - & - & - & - & - & - & - \\
\hline- & - & - & - & - & - & $* 9.7$ & *132.9 & *132.9 & & - & - & *8.4 \\
\hline- & - & - & - & - & - & - & - & - & *128.4 & - & - & - \\
\hline- & - & - & - & - & - & - & - & - & - & - & $* 23.5$ & - \\
\hline- & - & 19.2 & - & - & - & - & - & - & - & - & - & - \\
\hline- & - & - & - & - & - & - & - & - & - & - & - & - \\
\hline- & - & 24.2 & - & - & - & - & - & - & - & - & - & - \\
\hline- & - & - & - & - & - & - & - & - & - & - & - & - \\
\hline- & - & 22.7 & - & - & - & - & - & - & - & - & - & - \\
\hline- & - & - & - & - & - & - & - & - & $* 134.2$ & - & - & - \\
\hline- & - & - & - & - & - & - & - & - & - & - & - & *8.6 \\
\hline- & - & 24.7 & - & - & - & - & - & - & - & - & - & - \\
\hline- & - & - & - & - & - & - & - & - & - & - & - & - \\
\hline- & - & - & - & - & - & - & - & - & - & - & - & - \\
\hline- & - & - & - & - & - & - & - & - & - & - & - & - \\
\hline- & - & - & - & - & - & - & - & - & - & - & - & - \\
\hline- & - & - & - & - & - & - & - & - & - & - & - & - \\
\hline- & - & - & - & - & - & - & - & - & - & - & - & - \\
\hline- & - & 18.7 & - & - & - & - & - & - & - & - & - & - \\
\hline- & - & 24.4 & - & - & - & - & - & - & - & - & - & - \\
\hline- & - & 19.1 & - & - & - & - & - & - & - & - & - & - \\
\hline- & - & 17.5 & - & - & - & - & - & - & - & - & - & - \\
\hline- & - & 20.2 & - & - & - & - & - & - & - & - & - & - \\
\hline- & - & 18.7 & - & - & - & - & - & - & - & - & - & - \\
\hline- & - & 19.5 & - & - & - & - & - & - & - & - & - & - \\
\hline- & - & 20.1 & - & - & - & - & - & - & - & - & - & - \\
\hline- & - & 18.4 & - & - & - & - & - & - & - & - & - & - \\
\hline- & - & 21.7 & - & - & - & - & - & - & - & - & - & - \\
\hline- & - & 21.6 & - & - & - & - & - & - & - & - & - & - \\
\hline- & - & - & - & - & - & - & - & - & - & - & - & - \\
\hline
\end{tabular}


Table 4. Nitrate concentrations, in milligrams per liter as $\mathrm{NO}_{3}$, in ground water from wells in Warren ground-water basin, San Bernardino County, California, 1964-2001—Continued

\begin{tabular}{|c|c|c|c|c|c|c|c|c|c|c|c|c|}
\hline Date & $\begin{array}{c}\text { 1N/5E- } \\
36 \mathrm{~L} 1 \\
(7 \mathrm{E})\end{array}$ & $\begin{array}{c}\text { 1N/5E- } \\
36 K 3 \\
(14 E)\end{array}$ & $\begin{array}{c}1 \mathrm{~N} / 5 \mathrm{E}- \\
36 \mathrm{M} 4 \\
(12 \mathrm{E})\end{array}$ & $\begin{array}{c}1 \mathrm{~N} / 6 \mathrm{E}- \\
31 \mathrm{C1} \\
\text { (5E) }\end{array}$ & $\begin{array}{c}1 \mathrm{~N} / 5 \mathrm{E}- \\
36 \mathrm{~K} 2 \\
(9 \mathrm{E})\end{array}$ & $\begin{array}{c}\text { 1N/5E- } \\
36 \mathrm{M} 5 \\
\text { (16E) }\end{array}$ & $\begin{array}{c}\text { 1N/5E- } \\
36 \mathrm{M6} \\
\text { (17E) }\end{array}$ & $\begin{array}{c}1 \mathrm{~N} / 5 \mathrm{E}- \\
36 \mathrm{H} 2 \\
(18 \mathrm{E})\end{array}$ & $\begin{array}{l}1 \mathrm{~N} / 5 \mathrm{E} \\
34 \mathrm{~K} 2 \\
(2 \mathrm{~W})\end{array}$ & $\begin{array}{c}\text { 1N/5E- } \\
35 P 1 \\
(3 W)\end{array}$ & $\begin{array}{c}1 \mathrm{~N} / 5 \mathrm{E}- \\
3401 \\
(6 \mathrm{~W})\end{array}$ & $\begin{array}{c}\text { 1S/5E- } \\
\text { 3D1 } \\
\text { (8W) }\end{array}$ \\
\hline [Hydrogeologic units] & Midwest & Mideast & Midwest & Northeast & Midwest & Midwest & Midwest & Mideast & West & West & West & West \\
\hline $2 / 2 / 98$ & 62.6 & 19.2 & 26.1 & 8.4 & - & 9.7 & 44 & 9.5 & - & - & - & - \\
\hline 2/4/98 & - & - & - & - & 47.9 & - & - & 一 & - & - & - & - \\
\hline 2/9/98 & 69.2 & 25.4 & 25.2 & 8.2 & 52.6 & 11.1 & 44.6 & 7.8 & - & - & - & - \\
\hline 2/18/98 & 69.3 & 20.5 & 26.2 & 9.0 & 48.3 & 9.7 & 49 & 8.4 & - & - & - & - \\
\hline 2/23/98 & 65.1 & 21.8 & 25.9 & 8.7 & 51.3 & 10.5 & 46.7 & 2.0 & - & - & - & - \\
\hline $3 / 2 / 98$ & 58.0 & 18.5 & 27.2 & 23.6 & 47.2 & 9.7 & 46.4 & 6.4 & - & - & - & - \\
\hline 3/9/98 & 46.2 & 16.9 & 24.0 & 7.9 & 40.3 & 8.8 & 41.4 & 4.2 & - & - & - & - \\
\hline $3 / 16 / 98$ & 56.0 & 22.4 & 32.4 & 9.2 & 54.2 & 11.5 & 58 & 10.6 & - & - & - & - \\
\hline $3 / 23 / 98$ & 48.7 & 20.2 & 31.1 & 9.2 & 47.8 & 10.6 & 53.6 & 8.9 & 14.1 & 21.0 & - & - \\
\hline $3 / 24 / 98$ & - & - & - & - & - & - & - & - & - & - & - & - \\
\hline $3 / 25 / 98$ & - & - & - & - & - & - & - & - & - & - & - & - \\
\hline 3/30/98 & 54.2 & 27.1 & 38.7 & 10.3 & 54.8 & 11.2 & 65.2 & 10.8 & - & - & - & - \\
\hline 4/6/98 & 41.2 & 19.5 & - & 8.7 & 39.3 & 9.7 & 52.7 & 9.3 & - & - & - & - \\
\hline 4/13/98 & 39.1 & 19.4 & 31.9 & 8.9 & 44.3 & 9.4 & 52.5 & 8.3 & - & - & - & - \\
\hline 4/20/98 & 43.9 & 20.4 & 35.0 & 8.0 & 48.8 & 10.7 & 60.3 & 10.2 & - & - & - & - \\
\hline $4 / 27 / 98$ & 42.5 & 22.3 & 26.3 & 9.2 & 39.3 & 10.2 & 59.6 & 10.1 & - & - & - & - \\
\hline $5 / 4 / 98$ & 41.9 & 20.4 & 35.7 & 8.8 & 46.8 & 10.2 & 61.0 & 10.4 & - & - & - & - \\
\hline $5 / 7 / 98$ & - & - & - & - & - & - & $* 43.5$ & - & - & - & - & \\
\hline $5 / 8 / 98$ & - & - & - & - & - & - & $* 43.1$ & - & - & - & - & \\
\hline $5 / 11 / 98$ & 38.8 & 19.7 & 34.5 & 6.3 & 45.3 & 8.9 & 57.4 & 8.9 & - & - & - & - \\
\hline $5 / 18 / 98$ & 39.7 & 19.8 & 36.2 & 9.8 & 45.1 & 9.7 & 59.6 & 9.8 & - & - & - & - \\
\hline $5 / 27 / 98$ & 38.9 & 20.7 & 35.7 & 9.0 & 44.7 & 9.4 & 61.0 & 9.6 & - & - & - & - \\
\hline 6/1/98 & 39.9 & 19.8 & 33.1 & 9.2 & 45 & 9.4 & 61.4 & 8.7 & - & - & - & - \\
\hline 6/8/98 & 50.4 & 25.9 & 44.6 & 11.2 & 56 & 2.4 & 81.3 & 10.6 & - & - & - & - \\
\hline $6 / 10 / 98$ & - & - & - & - & - & - & - & - & - & - & - & - \\
\hline $6 / 11 / 98$ & - & - & - & - & - & - & - & - & - & - & - & - \\
\hline $6 / 12 / 98$ & - & - & - & - & - & - & - & - & - & - & - & - \\
\hline $6 / 15 / 98$ & 38.2 & 21.0 & 37.2 & 9.2 & 42.2 & 9.6 & 61.0 & 9.0 & - & - & - & - \\
\hline $6 / 22 / 98$ & 40.0 & 21.0 & 36.9 & 9.6 & 42.9 & 9.4 & 64.2 & 8.5 & - & - & - & - \\
\hline $6 / 29 / 98$ & 41.9 & 21.8 & 37.3 & 10.0 & 40.5 & 9.7 & 64.4 & 8.8 & - & - & - & - \\
\hline 7/6/98 & 48.2 & 21.4 & 40.9 & - & 48.2 & - & 72.3 & 9.4 & - & - & - & - \\
\hline 7/13/98 & 42.2 & 20.4 & 37.3 & 7.9 & 42.2 & 9.2 & 65.6 & 8.9 & - & - & - & - \\
\hline 7/20/98 & 41.1 & 16.5 & 36.9 & 9.6 & 41.1 & 9.2 & 66.6 & 8.4 & - & - & - & - \\
\hline 7/27/98 & 41.0 & 20.9 & 37.0 & 9.9 & 41.0 & 9.6 & 67.7 & 9.0 & - & - & - & - \\
\hline 8/3/98 & 46.0 & 24.3 & 38.8 & 10.3 & 46.0 & 8.6 & 73.0 & 9.0 & - & - & - & - \\
\hline 8/10/98 & 42.0 & 22.3 & 36.6 & 10.0 & 42.0 & 9.4 & 65.7 & 8.6 & - & - & - & - \\
\hline $8 / 17 / 98$ & 44.3 & 21.3 & 36.5 & 9.7 & 44.3 & 9.4 & 71.7 & 8.6 & - & - & - & - \\
\hline $8 / 24 / 98$ & 43.7 & 23.0 & 37.0 & 9.3 & 43.7 & 9.5 & 70.4 & 8.8 & - & - & - & - \\
\hline $8 / 31 / 98$ & 45.2 & 24.2 & 37.4 & 9.9 & 45.2 & 9.3 & 70.5 & 9.3 & - & - & - & - \\
\hline 9/9/98 & 46.1 & 22.7 & 36.7 & 9.8 & 46.1 & 9.5 & 68.0 & 8.6 & - & - & - & - \\
\hline 9/14/98 & 44.8 & 26.9 & 36.6 & 9.1 & 44.8 & 9.2 & 70.2 & 7.6 & - & - & - & - \\
\hline $9 / 21 / 98$ & 49.3 & 27.1 & 40.9 & 10.9 & 49.3 & 10.5 & 76.8 & 9.5 & - & - & - & - \\
\hline 9/28/98 & 44.6 & 23.9 & 37.4 & 9.7 & 44.6 & 9.5 & *62.9 & 9.0 & - & - & - & - \\
\hline $10 / 5 / 98$ & - & $* 25.3$ & - & - & - & - & $* 65.6$ & *10.6 & - & - & - & - \\
\hline $10 / 6 / 98$ & - & - & - & - & - & - & $* 65.6$ & - & - & - & - & - \\
\hline $10 / 7 / 98$ & - & - & - & - & - & - & $* 64.7$ & - & - & - & - & - \\
\hline
\end{tabular}


Table 4. Nitrate concentrations, in milligrams per liter as $\mathrm{NO}_{3}$, in ground water from wells in Warren ground-water basin, San Bernardino County, California, 1964-2001—Continued

\begin{tabular}{|c|c|c|c|c|c|c|c|c|c|c|c|c|}
\hline $\begin{array}{c}1 N / 5 E- \\
3402 \\
(9 W)\end{array}$ & $\begin{array}{c}1 \mathrm{~N} / 5 \mathrm{E}- \\
34 \mathrm{P4} \\
(10 \mathrm{~W})\end{array}$ & $\begin{array}{c}1 \mathrm{~N} / 5 \mathrm{E}- \\
35 \mathrm{~K} 1 \\
(11 \mathrm{~W})\end{array}$ & $\begin{array}{c}1 N / 5 E- \\
34 N 1 \\
(5 W)\end{array}$ & $\begin{array}{c}1 \mathrm{~N} / 6 \mathrm{E}- \\
29 \mathrm{J3} \\
(11 \mathrm{E})\end{array}$ & $\begin{array}{c}1 \mathrm{~N} / 6 \mathrm{E}- \\
29 \mathrm{R} 3 \\
(13 \mathrm{E})\end{array}$ & $\begin{array}{c}\text { 1N/5E- } \\
36 G 1 \\
\text { (YV1-570) }\end{array}$ & $\begin{array}{c}\text { 1N/5E- } \\
36 G 2 \\
\text { (YV1-400) }\end{array}$ & $\begin{array}{c}\text { 1N/5E- } \\
36 G 3 \\
\text { (YV1-305) }\end{array}$ & $\begin{array}{c}\text { 1N/5E- } \\
36 G 4 \\
\text { (YV1-230) }\end{array}$ & $\begin{array}{c}\text { 1N/5E- } \\
36 \mathrm{M} 1 \\
\text { (YV2-570) }\end{array}$ & $\begin{array}{c}\text { 1N/5E- } \\
36 \mathrm{M} 2 \\
\text { (YV2-390) }\end{array}$ & $\begin{array}{c}\text { 1N/5E- } \\
36 \mathrm{M} 3 \\
\text { (YV2-300) }\end{array}$ \\
\hline West & West & West & West & Northeast & Northeast & Mideast & Mideast & Mideast & Mideast & Midwest & Midwest & Midwest \\
\hline- & - & 16.1 & - & - & - & - & - & - & - & - & - & - \\
\hline- & - & - & - & - & - & - & - & - & - & - & - & - \\
\hline- & - & 16.4 & - & - & - & - & - & - & - & - & - & - \\
\hline- & - & 16.8 & - & - & - & - & - & - & - & - & - & - \\
\hline- & - & 15.6 & - & - & - & - & - & - & - & - & - & - \\
\hline- & - & 17.5 & - & - & - & - & - & - & - & - & - & - \\
\hline- & - & 14.7 & - & - & - & - & - & - & - & - & - & - \\
\hline- & - & 19.5 & - & - & - & - & - & - & - & - & - & - \\
\hline- & - & 19.3 & - & - & - & - & - & - & - & - & - & - \\
\hline- & - & - & - & - & - & - & - & - & - & $* 4.7$ & $* 7.1$ & $* 38.0$ \\
\hline- & - & - & - & - & - & $* 10.4$ & $* 103.2$ & $* 91.7$ & *109.8 & - & - & - \\
\hline- & - & 24.8 & - & - & - & - & - & - & - & - & - & - \\
\hline- & - & 17.0 & - & - & - & - & - & - & - & - & - & - \\
\hline- & - & 21.0 & - & - & - & - & - & - & - & - & - & - \\
\hline- & - & 22.7 & - & - & - & - & - & - & - & - & - & - \\
\hline- & - & 24.5 & - & - & - & - & - & - & - & - & - & - \\
\hline- & - & 27.3 & - & - & - & - & - & - & - & - & - & - \\
\hline- & - & - & - & - & - & - & - & - & - & - & - & - \\
\hline- & - & - & - & - & - & - & - & - & - & - & - & - \\
\hline- & - & 21.2 & - & - & - & - & - & - & - & - & - & - \\
\hline- & - & 21.7 & - & - & - & - & - & - & - & - & - & - \\
\hline- & - & 21.7 & - & - & - & - & - & - & - & - & - & - \\
\hline- & - & 21.6 & - & - & - & - & - & - & - & - & - & - \\
\hline- & - & 27.1 & - & - & - & - & - & - & - & - & - & - \\
\hline- & - & - & - & - & - & $* 10.1$ & $* 84.6$ & - & - & - & - & - \\
\hline- & - & - & - & - & - & - & - & - & - & - & $* 10.3$ & $* 20.1$ \\
\hline- & - & - & - & - & - & - & - & $* 124.0$ & $* 106.3$ & $* 49.6$ & - & - \\
\hline- & - & 21.6 & - & - & - & - & - & - & - & - & - & - \\
\hline- & - & 21.0 & - & - & - & - & - & - & - & - & - & - \\
\hline- & - & 21.9 & - & - & - & - & - & - & - & - & - & - \\
\hline- & - & 24.0 & - & - & - & - & - & - & - & - & - & - \\
\hline- & - & 22.0 & - & - & - & - & - & - & - & - & - & - \\
\hline- & - & 21.2 & - & - & - & - & - & - & - & - & - & - \\
\hline- & - & 22.3 & - & - & - & - & - & - & - & - & - & - \\
\hline- & - & 21.6 & - & - & - & - & - & - & - & - & - & - \\
\hline- & - & 22.6 & - & - & - & - & - & - & - & - & - & - \\
\hline- & - & 22.4 & - & - & - & - & - & - & - & - & - & - \\
\hline- & - & 22.7 & - & - & - & - & - & - & - & - & - & - \\
\hline- & - & 22.2 & - & - & - & - & - & - & - & - & - & - \\
\hline- & - & 22.3 & - & - & - & - & - & - & - & - & - & - \\
\hline- & - & - & - & - & - & - & - & - & - & - & - & - \\
\hline- & - & - & - & - & - & - & - & - & - & - & - & - \\
\hline- & - & - & - & - & - & - & - & - & - & - & - & - \\
\hline- & - & - & - & - & - & - & - & - & - & - & - & - \\
\hline- & - & - & - & - & - & - & - & - & - & - & - & - \\
\hline- & - & - & - & - & - & - & - & - & - & - & - & - \\
\hline
\end{tabular}


Table 4. Nitrate concentrations, in milligrams per liter as $\mathrm{NO}_{3}$, in ground water from wells in Warren ground-water basin, San Bernardino County, California, 1964-2001—Continued

\begin{tabular}{|c|c|c|c|c|c|c|c|c|c|c|c|c|}
\hline Date & $\begin{array}{c}\text { 1N/5E- } \\
36 \mathrm{~L} 1 \\
(7 \mathrm{E})\end{array}$ & $\begin{array}{c}1 \mathrm{~N} / 5 \mathrm{E}- \\
36 \mathrm{~K} 3 \\
(14 \mathrm{E})\end{array}$ & $\begin{array}{c}1 \mathrm{~N} / 5 \mathrm{E}- \\
36 \mathrm{M} 4 \\
(12 \mathrm{E})\end{array}$ & $\begin{array}{c}1 \mathrm{~N} / 6 \mathrm{E}- \\
31 \mathrm{C1} \\
\text { (5E) }\end{array}$ & $\begin{array}{c}\text { 1N/5E- } \\
36 \mathrm{~K} 2 \\
(9 \mathrm{E})\end{array}$ & $\begin{array}{c}\text { 1N/5E- } \\
36 \mathrm{M} 5 \\
\text { (16E) }\end{array}$ & $\begin{array}{c}\text { 1N/5E- } \\
36 \mathrm{M} 6 \\
\text { (17E) }\end{array}$ & $\begin{array}{c}\text { 1N/5E- } \\
36 \mathrm{H} 2 \\
(18 \mathrm{E})\end{array}$ & $\begin{array}{c}1 N / 5 E \\
34 K 2 \\
(2 W)\end{array}$ & $\begin{array}{c}\text { 1N/5E- } \\
35 P 1 \\
(3 W)\end{array}$ & $\begin{array}{c}1 \mathrm{~N} / 5 \mathrm{E}- \\
3401 \\
(6 \mathrm{~W})\end{array}$ & $\begin{array}{c}\text { 1S/5E- } \\
\text { 3D1 } \\
(8 W)\end{array}$ \\
\hline [Hydrogeologic units] & Midwest & Mideast & Midwest & Northeast & Midwest & Midwest & Midwest & Mideast & West & West & West & West \\
\hline $10 / 8 / 98$ & - & - & - & - & - & - & $* 64.7$ & - & - & - & - & - \\
\hline $10 / 12 / 98$ & 15.0 & 24.7 & 37.5 & 9.4 & 13 & 9.4 & - & 9.3 & - & - & - & - \\
\hline $10 / 19 / 98$ & 45.6 & 25.3 & 37.3 & 9.7 & 37.1 & 9.6 & - & 9.2 & - & - & - & 8.5 \\
\hline $10 / 26 / 98$ & 46.9 & 25.4 & 38.2 & 10.2 & 38.6 & 9.6 & - & 8.8 & - & 20.7 & - & - \\
\hline $11 / 4 / 98$ & 39.5 & 24.4 & 36.3 & 9.9 & 43.0 & 9.6 & - & 8.7 & - & - & - & - \\
\hline $11 / 9 / 98$ & 46.6 & 28.4 & 39.8 & 11.2 & 45.3 & 10.7 & - & 10.1 & - & - & - & - \\
\hline $11 / 16 / 98$ & 43.1 & 25.8 & 36.4 & 9.6 & 39.3 & 9.3 & - & 8.4 & - & - & - & - \\
\hline $11 / 23 / 98$ & 44.0 & 23.8 & 37.7 & 9.6 & 38.4 & 9.6 & - & 8.6 & - & - & - & - \\
\hline $11 / 30 / 98$ & 45.4 & 26.6 & 38.0 & 8.9 & 42.0 & 9.9 & - & 9.0 & - & - & - & - \\
\hline $12 / 7 / 98$ & 44.3 & - & 36.4 & 9.6 & - & 9.5 & - & 8.7 & - & - & - & - \\
\hline $12 / 14 / 98$ & 43.0 & 26.0 & 37.5 & 9.5 & 39.0 & 9.5 & - & 8.6 & - & - & - & - \\
\hline $12 / 21 / 98$ & 41.9 & 31.0 & 37.0 & 9.4 & 38.1 & 9.3 & - & 8.6 & - & - & - & - \\
\hline $12 / 28 / 98$ & 41.8 & 25.1 & 37.6 & 9.5 & 36.9 & 9.3 & - & 8.7 & - & - & - & - \\
\hline $1 / 4 / 99$ & 43.1 & 25.5 & 37.8 & 9.5 & 37.7 & 9.3 & - & 8.3 & - & - & - & - \\
\hline $1 / 11 / 99$ & 43.9 & 26.0 & 39.3 & 9.7 & 38.7 & 9.8 & - & 8.9 & - & - & - & - \\
\hline $1 / 13 / 99$ & - & - & - & - & - & - & - & - & 12.3 & - & 11.2 & - \\
\hline 1/18/99 & 43.3 & 29.7 & 39.5 & 10.2 & 36.2 & 9.7 & - & 8.8 & - & - & - & - \\
\hline $1 / 25 / 99$ & 43.7 & 26.0 & 39.5 & 10.2 & 37.2 & 9.8 & - & 8.7 & - & - & - & - \\
\hline 2/1/99 & 44.2 & 26.6 & 51.6 & 9.0 & 36.9 & 10.1 & - & 8.9 & - & - & - & - \\
\hline 2/8/99 & 44.4 & 26.6 & 41.4 & - & 39.3 & 10.3 & - & 9.4 & - & - & - & - \\
\hline 2/11/99 & - & - & 40.0 & - & - & - & - & - & - & - & - & - \\
\hline 2/17/99 & 44.0 & 29.3 & 40.4 & 10.5 & - & 10.0 & - & 8.7 & - & - & - & - \\
\hline 2/21/99 & - & 32.9 & - & - & - & - & - & - & - & - & - & - \\
\hline 2/22/99 & 48.6 & - & 45.1 & 12.0 & - & 11.1 & - & 10.1 & - & - & - & - \\
\hline 3/1/99 & - & 26.9 & 41.7 & - & - & - & - & - & - & - & - & - \\
\hline 3/8/99 & - & 25.8 & 44.3 & - & - & - & - & - & - & - & - & - \\
\hline 3/9/99 & - & - & - & - & - & - & - & - & - & - & - & - \\
\hline 3/10/99 & - & - & - & - & - & - & - & - & - & - & - & - \\
\hline $3 / 11 / 99$ & - & - & - & - & - & - & - & - & - & - & - & - \\
\hline $3 / 15 / 99$ & - & 23.5 & 41.2 & - & - & - & - & - & - & - & - & - \\
\hline $3 / 22 / 99$ & - & 26.1 & 41.6 & - & - & - & - & - & - & - & - & - \\
\hline $3 / 29 / 99$ & - & 24.8 & 41.6 & - & - & - & - & - & - & - & - & - \\
\hline 4/2/99 & - & - & - & - & 30.6 & - & - & - & - & - & - & - \\
\hline 4/5/99 & 43.0 & 24.1 & 41.5 & 10.8 & & 9.5 & 73.9 & 8.6 & - & - & - & - \\
\hline 4/7/99 & - & - & - & - & - & - & - & - & - & - & - & - \\
\hline 4/8/99 & - & - & - & - & - & - & - & - & - & - & - & - \\
\hline 4/12/99 & - & 26.5 & 46.3 & 11.5 & $* 30.6$ & - & - & $* 10.0$ & - & - & - & - \\
\hline 4/14/99 & - & $* 23.4$ & - & - & - & $* 9.7$ & - & $* 9.0$ & - & *23.6 & - & 4.5 \\
\hline 4/15/99 & - & - & - & - & - & - & - & - & - & - & - & $* 8.1$ \\
\hline 4/19/99 & 46.0 & 24.3 & 43.2 & 11.3 & - & 10.3 & 82.2 & 10.0 & - & - & - & - \\
\hline 4/26/99 & 43.5 & 21.9 & 42.4 & 11.2 & - & 9.9 & 73.4 & 8.5 & - & - & - & - \\
\hline $5 / 3 / 99$ & 44.4 & 25.4 & 42.3 & 10.9 & - & 10.2 & 75.5 & 8.8 & - & - & - & - \\
\hline $5 / 11 / 99$ & 41.0 & 21.9 & 40.6 & 10.9 & - & 9.6 & 71.4 & 8.5 & - & - & - & - \\
\hline $5 / 17 / 99$ & 42.8 & 24.5 & 41.5 & 10.7 & - & 9.9 & 66.5 & 8.7 & - & - & - & - \\
\hline $5 / 24 / 99$ & - & 25.1 & - & 11.5 & - & 10.3 & - & 9.2 & - & - & - & - \\
\hline 6/2/99 & - & 21.6 & - & 11.6 & - & 9.9 & - & 8.7 & - & - & - & - \\
\hline
\end{tabular}


Table 4. Nitrate concentrations, in milligrams per liter as $\mathrm{NO}_{3}$, in ground water from wells in Warren ground-water basin, San Bernardino County, California, 1964-2001—Continued

\begin{tabular}{|c|c|c|c|c|c|c|c|c|c|c|c|c|}
\hline $\begin{array}{c}1 N / 5 E- \\
3402 \\
(9 W)\end{array}$ & $\begin{array}{c}1 \mathrm{~N} / 5 \mathrm{E}- \\
34 \mathrm{P4} \\
(10 \mathrm{~W})\end{array}$ & $\begin{array}{c}1 \mathrm{~N} / 5 \mathrm{E}- \\
35 \mathrm{~K} 1 \\
(11 W)\end{array}$ & $\begin{array}{c}1 N / 5 E- \\
34 N 1 \\
(5 W)\end{array}$ & $\begin{array}{c}1 \mathrm{~N} / 6 \mathrm{E}- \\
29 \mathrm{J3} \\
(11 \mathrm{E})\end{array}$ & $\begin{array}{c}1 \mathrm{~N} / 6 \mathrm{E}- \\
29 \mathrm{R} 3 \\
(13 \mathrm{E})\end{array}$ & $\begin{array}{c}\text { 1N/5E- } \\
36 G 1 \\
\text { (YV1-570) }\end{array}$ & $\begin{array}{c}\text { 1N/5E- } \\
36 G 2 \\
\text { (YV1-400) }\end{array}$ & $\begin{array}{c}\text { 1N/5E- } \\
36 G 3 \\
\text { (YV1-305) }\end{array}$ & $\begin{array}{c}\text { 1N/5E- } \\
36 G 4 \\
\text { (YV1-230) }\end{array}$ & $\begin{array}{c}\text { 1N/5E- } \\
36 \mathrm{M} 1 \\
\text { (YV2-570) }\end{array}$ & $\begin{array}{c}\text { 1N/5E- } \\
36 \mathrm{M} 2 \\
\text { (YV2-390) }\end{array}$ & $\begin{array}{c}\text { 1N/5E- } \\
36 \mathrm{M} 3 \\
(\mathrm{YV} 2-300)\end{array}$ \\
\hline West & West & West & West & Northeast & Northeast & Mideast & Mideast & Mideast & Mideast & Midwest & Midwest & Midwest \\
\hline- & - & - & - & - & - & - & - & - & - & - & - & - \\
\hline- & - & - & - & - & - & - & - & - & - & - & - & - \\
\hline- & 6.6 & - & - & - & - & - & - & - & - & - & - & - \\
\hline- & - & - & - & - & - & - & - & - & - & - & - & - \\
\hline- & - & - & - & - & - & - & - & - & - & - & - & - \\
\hline- & - & - & - & - & - & - & - & - & - & - & - & - \\
\hline- & - & - & - & - & - & - & - & - & - & - & - & - \\
\hline- & - & - & - & - & - & - & - & - & - & - & - & - \\
\hline- & - & - & - & - & - & - & - & - & - & - & - & - \\
\hline- & - & - & - & - & - & - & - & - & - & - & - & - \\
\hline- & - & - & - & - & - & - & - & - & - & - & - & - \\
\hline- & - & - & - & - & - & - & - & - & - & - & - & - \\
\hline- & - & - & - & - & - & - & - & - & - & - & - & - \\
\hline- & - & - & - & - & - & - & - & - & - & - & - & - \\
\hline- & - & - & - & - & - & - & - & - & - & - & - & - \\
\hline$* 10.9$ & - & - & - & - & - & - & - & - & - & - & - & - \\
\hline- & - & - & - & - & - & - & - & - & - & - & - & - \\
\hline- & - & - & - & - & - & - & - & - & - & - & - & - \\
\hline- & - & - & - & - & - & - & - & - & - & - & - & - \\
\hline- & - & - & - & - & - & - & - & - & - & - & - & - \\
\hline- & - & - & - & - & - & - & - & - & - & - & - & - \\
\hline- & - & - & - & - & - & - & - & - & - & - & - & - \\
\hline- & - & - & - & - & - & - & - & - & - & - & - & - \\
\hline- & - & - & - & - & - & - & - & - & - & - & - & - \\
\hline- & - & - & - & - & - & - & - & - & - & - & - & - \\
\hline- & - & - & - & - & - & - & - & - & - & - & - & - \\
\hline- & - & - & - & - & - & - & - & - & - & $* 49.2$ & $* 13.6$ & - \\
\hline- & - & - & - & - & - & $* 10.0$ & *88.6 & $* 150.2$ & - & - & - & $* 8.8$ \\
\hline- & - & - & - & - & - & - & - & - & $* 70.9$ & - & - & - \\
\hline- & - & - & - & - & - & - & - & - & - & - & - & - \\
\hline- & - & - & - & - & - & - & - & - & - & - & - & - \\
\hline- & - & - & - & - & - & - & - & - & - & - & - & - \\
\hline- & - & - & - & - & - & - & - & - & - & - & - & - \\
\hline- & - & - & - & - & - & - & - & - & - & - & - & - \\
\hline- & - & $* 11.0$ & - & - & - & - & - & - & - & - & - & - \\
\hline- & - & $* 13.6$ & - & - & - & - & - & - & - & - & - & - \\
\hline- & - & - & - & - & - & - & - & - & - & - & - & - \\
\hline 9.7 & 5.8 & - & - & - & - & - & - & - & - & - & - & - \\
\hline 10.9 & - & - & - & - & - & - & - & - & - & - & - & - \\
\hline- & - & - & - & - & - & - & - & - & - & - & - & - \\
\hline- & - & - & - & - & - & - & - & - & - & - & - & - \\
\hline- & - & - & - & - & - & - & - & - & - & - & - & - \\
\hline- & - & - & - & - & - & - & - & - & - & - & - & - \\
\hline- & - & - & - & - & - & - & - & - & - & - & - & - \\
\hline- & - & - & - & - & - & - & - & - & - & - & - & - \\
\hline- & - & - & - & - & - & - & - & - & - & - & - & - \\
\hline
\end{tabular}


Table 4. Nitrate concentrations, in milligrams per liter as $\mathrm{NO}_{3}$, in ground water from wells in Warren ground-water basin, San Bernardino County, California, 1964-2001—Continued

\begin{tabular}{|c|c|c|c|c|c|c|c|c|c|c|c|c|}
\hline Date & $\begin{array}{c}\text { 1N/5E- } \\
36 \mathrm{~L} 1 \\
(7 \mathrm{E})\end{array}$ & $\begin{array}{c}1 \mathrm{~N} / 5 \mathrm{E}- \\
36 \mathrm{~K} 3 \\
(14 \mathrm{E})\end{array}$ & $\begin{array}{c}1 \mathrm{~N} / 5 \mathrm{E}- \\
36 \mathrm{M} 4 \\
(12 \mathrm{E})\end{array}$ & $\begin{array}{c}1 \mathrm{~N} / 6 \mathrm{E}- \\
31 \mathrm{C1} \\
\text { (5E) }\end{array}$ & $\begin{array}{c}1 \mathrm{~N} / 5 \mathrm{E}- \\
36 \mathrm{~K} 2 \\
(9 \mathrm{E})\end{array}$ & $\begin{array}{c}\text { 1N/5E- } \\
36 \mathrm{M} 5 \\
\text { (16E) }\end{array}$ & $\begin{array}{c}\text { 1N/5E- } \\
36 \mathrm{M6} \\
\text { (17E) }\end{array}$ & $\begin{array}{c}1 \mathrm{~N} / 5 \mathrm{E}- \\
36 \mathrm{H} 2 \\
(18 \mathrm{E})\end{array}$ & $\begin{array}{l}1 \mathrm{~N} / 5 \mathrm{E} \\
34 \mathrm{~K} 2 \\
(2 \mathrm{~W})\end{array}$ & $\begin{array}{c}\text { 1N/5E- } \\
35 P 1 \\
(3 W)\end{array}$ & $\begin{array}{c}1 \mathrm{~N} / 5 \mathrm{E}- \\
3401 \\
(6 \mathrm{~W})\end{array}$ & $\begin{array}{c}\text { 1S/5E- } \\
\text { 3D1 } \\
(8 W)\end{array}$ \\
\hline [Hydrogeologic units] & Midwest & Mideast & Midwest & Northeast & Midwest & Midwest & Midwest & Mideast & West & West & West & West \\
\hline $6 / 7 / 99$ & - & 21.9 & - & 11.7 & - & 10.0 & - & 8.7 & - & - & - & - \\
\hline $6 / 14 / 99$ & 44.0 & 22.9 & 42.8 & 11.7 & - & 10.0 & 71.5 & 8.5 & - & - & - & - \\
\hline $6 / 21 / 99$ & 44.0 & 21.1 & 42.4 & 11.8 & - & 9.9 & 71 & 8.6 & - & - & - & - \\
\hline $6 / 28 / 99$ & 44.0 & 21.1 & 42.8 & 11.9 & - & 10.0 & 66.5 & 8.6 & - & - & - & - \\
\hline 7/7/99 & 43.8 & 23.7 & 43.0 & 12.0 & - & 10.0 & 70.2 & 8.6 & - & - & - & - \\
\hline 7/12/99 & 44.0 & 23.0 & 42.8 & 11.8 & - & 9.9 & 66.7 & 8.4 & - & - & - & - \\
\hline 7/14/99 & - & - & - & - & - & - & - & - & 13.2 & 32.9 & 11.4 & - \\
\hline 7/21/99 & 42.6 & 21.1 & 42.4 & 11.8 & - & 9.5 & 69.9 & 8.6 & - & - & - & - \\
\hline 7/26/99 & - & 19.8 & - & 12.1 & - & 10.2 & 68.3 & 8.6 & - & - & - & - \\
\hline $8 / 2 / 99$ & 44.6 & 22.7 & 43.0 & 12.1 & - & 10.1 & 66.9 & 8.6 & - & - & - & - \\
\hline 8/9/99 & 45.7 & 42.9 & 25.0 & 12.3 & - & 10.2 & 64.7 & 8.6 & - & - & - & - \\
\hline 8/16/99 & 43.0 & 22.1 & 44.2 & 12.3 & - & 9.9 & 71.0 & 7.3 & - & - & - & - \\
\hline $8 / 23 / 99$ & - & 21.0 & 43.8 & 12.5 & - & 10.1 & 66.3 & 8.5 & - & - & - & - \\
\hline 8/30/99 & 41.6 & - & 43.8 & 12.3 & - & 10.2 & 65.1 & 8.5 & - & - & - & - \\
\hline 9/8/99 & 45.3 & - & 44.3 & - & - & 10.0 & 68.3 & 8.5 & - & - & - & - \\
\hline 9/13/99 & 43.5 & - & 44.5 & 8.8 & - & 10.2 & 66.1 & 8.5 & - & - & - & - \\
\hline 9/20/99 & 44.2 & - & 44.6 & 11.1 & - & 10.4 & - & 8.6 & - & - & - & - \\
\hline $9 / 27 / 99$ & 43.8 & - & 44.9 & 12.4 & - & 10.3 & 64.5 & 8.6 & - & - & - & - \\
\hline $10 / 6 / 99$ & 45.1 & - & 45.1 & - & - & - & 64.6 & - & - & - & - & - \\
\hline $10 / 11 / 99$ & 44.0 & - & 46.3 & 11.9 & - & 10.9 & 66.3 & 7.8 & - & - & - & - \\
\hline $10 / 15 / 99$ & - & - & - & - & - & - & - & - & - & - & - & - \\
\hline $10 / 18 / 99$ & 42.7 & - & - & 10.2 & - & 10.1 & 62.5 & 8.4 & - & - & - & 8.05 \\
\hline $10 / 27 / 99$ & 40.4 & - & - & 12.6 & - & 10.6 & 64.3 & 8.6 & - & - & - & - \\
\hline $11 / 1 / 99$ & 40.9 & - & - & 12.2 & - & 10.5 & 65.5 & 8.6 & - & - & - & - \\
\hline 11/8/99 & 42.2 & - & - & 12.2 & - & 10.4 & 65.7 & 8.5 & - & - & - & - \\
\hline $11 / 15 / 99$ & 41.9 & - & - & 12.8 & - & 10.5 & 64.0 & 8.9 & - & - & - & - \\
\hline $11 / 22 / 99$ & - & - & - & 12.9 & - & 10.6 & 8.6 & - & - & - & - & - \\
\hline $11 / 29 / 99$ & 47.4 & - & - & 14.4 & - & 12.1 & 72.6 & 9.9 & - & - & - & - \\
\hline $12 / 6 / 99$ & 42.0 & - & - & 13.0 & - & 11.1 & 58.8 & 8.3 & - & - & - & - \\
\hline $12 / 13 / 99$ & 51.2 & - & - & 14.8 & - & 10.9 & 62.5 & 8.6 & - & - & - & - \\
\hline $12 / 20 / 99$ & - & - & - & 13.3 & - & 10.8 & - & 9.2 & - & - & - & - \\
\hline $12 / 27 / 99$ & 47.0 & - & - & 12.3 & - & - & 63.7 & 8.9 & - & - & - & - \\
\hline $1 / 3 / 00$ & 45.9 & - & - & - & - & 11.2 & 63.2 & 9.5 & - & - & - & - \\
\hline $1 / 10 / 00$ & 45.8 & - & - & 13.7 & - & 11.2 & 62.1 & 8.8 & - & - & - & - \\
\hline $1 / 12 / 00$ & - & - & - & - & - & - & - & - & 14.0 & 32.5 & - & - \\
\hline $1 / 17 / 00$ & 46.7 & - & - & - & - & 11.6 & 65.1 & 9.6 & - & - & - & - \\
\hline $1 / 18 / 00$ & - & - & - & - & - & - & - & - & - & - & 11.1 & - \\
\hline $1 / 24 / 00$ & 45.3 & - & - & 13.3 & - & 11.0 & 59.7 & 9.3 & - & - & - & - \\
\hline $1 / 31 / 00$ & 48.2 & - & - & 13.8 & - & 11.5 & 64.3 & 9.0 & - & - & - & - \\
\hline $2 / 7 / 00$ & 42.7 & - & 25.8 & 13.4 & - & 11.6 & 63.0 & 8.7 & - & - & - & - \\
\hline $2 / 14 / 00$ & 48.9 & - & - & 13.5 & - & 11.2 & 62.6 & 8.6 & - & - & - & - \\
\hline $2 / 23 / 00$ & 48.0 & - & - & 13.4 & - & 11.0 & 59.8 & 8.5 & - & - & - & - \\
\hline $2 / 28 / 00$ & 44.4 & - & - & 13.5 & - & 10.7 & 60.6 & 8.8 & - & - & - & - \\
\hline $3 / 6 / 00$ & 46.5 & - & - & 14.4 & - & 11.4 & 60.5 & 8.8 & - & - & - & - \\
\hline $3 / 13 / 00$ & - & - & - & 13.9 & - & - & - & 8.9 & - & - & - & - \\
\hline $3 / 20 / 00$ & 45.0 & - & - & 13.9 & - & 11.3 & 64.0 & 8.6 & - & - & - & - \\
\hline
\end{tabular}


Table 4. Nitrate concentrations, in milligrams per liter as $\mathrm{NO}_{3}$, in ground water from wells in Warren ground-water basin, San Bernardino County, California, 1964-2001—Continued

\begin{tabular}{|c|c|c|c|c|c|c|c|c|c|c|c|c|}
\hline $\begin{array}{l}1 \mathrm{~N} / 5 \mathrm{E}- \\
3402 \\
(9 \mathrm{~W})\end{array}$ & $\begin{array}{c}1 \mathrm{~N} / 5 \mathrm{E}- \\
34 \mathrm{P4} \\
(10 \mathrm{~W})\end{array}$ & $\begin{array}{c}1 \mathrm{~N} / 5 \mathrm{E}- \\
35 \mathrm{~K} 1 \\
(11 \mathrm{~W})\end{array}$ & $\begin{array}{l}1 \mathrm{~N} / 5 \mathrm{E}- \\
34 \mathrm{~N} 1 \\
(5 \mathrm{~W})\end{array}$ & $\begin{array}{c}1 \mathrm{~N} / 6 \mathrm{E}- \\
29 \mathrm{J3} \\
(11 \mathrm{E})\end{array}$ & $\begin{array}{c}1 \mathrm{~N} / 6 \mathrm{E}- \\
29 \mathrm{R} 3 \\
(13 \mathrm{E})\end{array}$ & $\begin{array}{c}\text { 1N/5E- } \\
36 G 1 \\
\text { (YV1-570) }\end{array}$ & $\begin{array}{c}\text { 1N/5E- } \\
36 G 2 \\
\text { (YV1-400) }\end{array}$ & $\begin{array}{c}\text { 1N/5E- } \\
36 G 3 \\
\text { (YV1-305) }\end{array}$ & $\begin{array}{c}\text { 1N/5E- } \\
36 G 4 \\
\text { (YV1-230) }\end{array}$ & $\begin{array}{c}\text { 1N/5E- } \\
36 \mathrm{M} 1 \\
\text { (YV2-570) }\end{array}$ & $\begin{array}{c}\text { 1N/5E- } \\
36 \mathrm{M} 2 \\
(\mathrm{YV2-390})\end{array}$ & $\begin{array}{c}\text { 1N/5E- } \\
36 \mathrm{M3} \\
\text { (YV2-300) }\end{array}$ \\
\hline West & West & West & West & Northeast & Northeast & Mideast & Mideast & Mideast & Mideast & Midwest & Midwest & Midwest \\
\hline- & - & - & - & - & - & - & - & - & - & - & - & - \\
\hline- & - & - & - & - & - & - & - & - & - & - & - & - \\
\hline- & - & - & - & - & - & - & - & - & - & - & - & - \\
\hline- & - & - & - & - & - & - & - & - & - & - & - & - \\
\hline- & - & 20.5 & - & - & - & - & - & - & - & - & - & - \\
\hline- & - & 22.4 & - & - & - & - & - & - & - & - & - & - \\
\hline 9.5 & - & - & - & - & - & - & - & - & - & - & - & - \\
\hline- & - & 23.9 & - & - & - & - & - & - & - & - & - & - \\
\hline- & - & 23.2 & - & - & - & - & - & - & - & - & - & - \\
\hline- & - & 24.4 & - & - & - & - & - & - & - & - & - & - \\
\hline- & - & 24.6 & - & - & - & - & - & - & - & - & - & - \\
\hline- & - & 24.8 & - & - & - & - & - & - & - & - & - & - \\
\hline- & - & - & - & - & - & - & - & - & - & - & - & - \\
\hline- & - & 22.9 & - & - & - & - & - & - & - & - & - & - \\
\hline- & - & 25.3 & - & - & - & - & - & - & - & - & - & - \\
\hline- & - & 28.5 & - & - & - & - & - & - & - & - & - & - \\
\hline- & - & 25.3 & - & - & - & - & - & - & - & - & - & - \\
\hline- & - & - & - & - & - & - & - & - & - & - & - & - \\
\hline- & - & 26.6 & - & - & - & - & - & - & - & - & - & - \\
\hline- & - & 33.4 & - & - & - & - & - & - & - & - & - & - \\
\hline- & 6.9 & - & - & - & - & - & - & - & - & - & - & - \\
\hline- & - & 25.4 & - & - & - & - & - & - & - & - & - & - \\
\hline- & - & 24 & - & - & - & - & - & - & - & - & - & - \\
\hline- & - & 24.8 & - & - & - & - & - & - & - & - & - & - \\
\hline- & - & - & - & - & - & - & - & - & - & - & - & - \\
\hline- & - & 21.8 & - & - & - & - & - & - & - & - & - & - \\
\hline- & - & - & - & - & - & - & - & - & - & - & - & - \\
\hline- & - & - & - & - & - & - & - & - & - & - & - & - \\
\hline- & - & - & - & - & - & - & - & - & - & - & - & - \\
\hline- & - & - & - & - & - & - & - & - & - & - & - & - \\
\hline- & - & 21.9 & - & - & - & - & - & - & - & - & - & - \\
\hline- & - & - & - & - & - & - & - & - & - & - & - & - \\
\hline- & - & - & - & - & - & - & - & - & - & - & - & - \\
\hline- & - & - & - & - & - & - & - & - & - & - & - & - \\
\hline- & - & - & - & - & - & - & - & - & - & - & - & - \\
\hline- & - & 27.7 & - & - & - & - & - & - & - & - & - & - \\
\hline- & - & - & - & - & - & - & - & - & - & - & - & - \\
\hline- & - & - & - & - & - & - & - & - & - & - & - & - \\
\hline- & - & 27.4 & - & - & - & - & - & - & - & - & - & - \\
\hline- & - & 26.3 & - & - & - & - & - & - & - & - & - & - \\
\hline- & - & 25.5 & - & - & - & - & - & - & - & - & - & - \\
\hline- & - & 24.8 & - & - & - & - & - & - & - & - & - & - \\
\hline- & - & 24.0 & - & - & - & - & - & - & - & - & - & - \\
\hline- & - & 26.0 & - & - & - & - & - & - & - & - & - & - \\
\hline- & - & 24.6 & - & - & - & - & - & - & - & - & - & - \\
\hline- & - & 25.2 & - & - & - & - & - & - & - & - & - & - \\
\hline
\end{tabular}


Table 4. Nitrate concentrations, in milligrams per liter as $\mathrm{NO}_{3}$, in ground water from wells in Warren ground-water basin, San Bernardino County, California, 1964-2001-Continued

\begin{tabular}{|c|c|c|c|c|c|c|c|c|c|c|c|c|}
\hline Date & $\begin{array}{c}\text { 1N/5E- } \\
36 \mathrm{~L} 1 \\
\text { (7E) }\end{array}$ & $\begin{array}{c}\text { 1N/5E- } \\
36 K 3 \\
\text { (14E) }\end{array}$ & $\begin{array}{c}\text { 1N/5E- } \\
36 \mathrm{M} 4 \\
(12 \mathrm{E})\end{array}$ & $\begin{array}{c}1 \mathrm{~N} / 6 \mathrm{E}- \\
31 \mathrm{C1} \\
(5 \mathrm{E})\end{array}$ & $\begin{array}{c}\text { 1N/5E- } \\
36 K 2 \\
(9 E)\end{array}$ & $\begin{array}{c}\text { 1N/5E- } \\
36 \mathrm{M} 5 \\
\text { (16E) }\end{array}$ & $\begin{array}{c}\text { 1N/5E- } \\
36 \mathrm{M} 6 \\
\text { (17E) }\end{array}$ & $\begin{array}{c}\text { 1N/5E- } \\
36 \mathrm{H} 2 \\
(18 \mathrm{E})\end{array}$ & $\begin{array}{c}1 N / 5 E \\
34 K 2 \\
(2 W)\end{array}$ & $\begin{array}{c}\text { 1N/5E- } \\
35 P 1 \\
(3 W)\end{array}$ & $\begin{array}{c}1 N / 5 E- \\
3401 \\
(6 W)\end{array}$ & $\begin{array}{c}\text { 1S/5E- } \\
\text { 3D1 } \\
(8 W)\end{array}$ \\
\hline [Hydrogeologic units] & Midwest & Mideast & Midwest & Northeast & Midwest & Midwest & Midwest & Mideast & West & West & West & West \\
\hline $3 / 27 / 00$ & 43.2 & - & - & 13.7 & - & - & 59.2 & 8.4 & - & - & - & - \\
\hline $4 / 3 / 00$ & - & - & - & 14.4 & - & - & - & 8.6 & - & - & - & - \\
\hline $4 / 5 / 00$ & - & - & $* 45.6$ & $* 14.4$ & - & - & - & $* 8.6$ & - & - & - & $* 8.4$ \\
\hline $4 / 10 / 00$ & 43.2 & - & - & - & - & 11.5 & 59.6 & 8.6 & - & - & - & 8.4 \\
\hline $4 / 12 / 00$ & - & - & - & - & - & - & - & - & - & - & - & 8.4 \\
\hline $4 / 14 / 00$ & - & - & - & - & - & - & - & - & - & - & - & - \\
\hline $4 / 19 / 00$ & 41.3 & - & 47.4 & 14.4 & - & 16.6 & 57.7 & 8.9 & - & - & - & - \\
\hline $4 / 24 / 00$ & 40.5 & - & - & 14.7 & - & 11.3 & 64.4 & 8.5 & - & - & - & - \\
\hline $5 / 3 / 00$ & 39.8 & - & 48.8 & 15.3 & - & 11.6 & 61.3 & 8.7 & - & - & - & - \\
\hline $5 / 8 / 00$ & 39.2 & - & 47.8 & 14.6 & - & 11.5 & 55.4 & - & - & - & - & - \\
\hline $5 / 15 / 00$ & 38.2 & - & 48.5 & 15.6 & - & 11.7 & 56.7 & 7.4 & - & - & - & - \\
\hline $5 / 22 / 00$ & 38.4 & & 49.2 & 16.0 & - & 11.9 & 59.8 & 8.8 & - & - & - & - \\
\hline $5 / 24 / 00$ & - & 23.0 & - & - & - & - & - & - & - & - & - & - \\
\hline $5 / 25 / 00$ & - & 23.1 & - & - & - & - & - & - & - & - & - & - \\
\hline $5 / 31 / 00$ & 38.2 & 23.6 & 50.2 & 16.6 & - & 11.9 & 59.6 & - & - & - & - & - \\
\hline $6 / 5 / 00$ & 36.5 & - & 49.0 & 16.2 & - & 11.7 & 58.3 & 8.6 & - & - & - & - \\
\hline $6 / 12 / 00$ & 37.0 & 23.7 & 49.3 & 17.3 & - & 12.2 & 59.7 & 9.3 & - & - & - & - \\
\hline $6 / 19 / 00$ & 35.9 & - & 44.0 & 17.7 & - & 11.9 & 50.2 & - & - & - & - & - \\
\hline $6 / 26 / 00$ & 35.0 & - & 50.2 & 17.4 & - & 12.2 & 58.3 & 9.2 & - & - & - & - \\
\hline $7 / 3 / 00$ & 34.0 & 22.4 & 49.9 & 17.8 & - & 12.3 & 58.6 & - & - & - & - & - \\
\hline $7 / 10 / 00$ & - & 22.6 & - & 17.6 & - & 12.3 & - & 8.6 & - & - & - & - \\
\hline $7 / 11 / 00$ & - & - & - & - & - & - & - & - & 14.0 & 33.5 & 11.6 & - \\
\hline $7 / 17 / 00$ & 33.4 & 22.0 & 50.5 & 18.3 & - & 12.3 & 58.4 & 8.8 & - & - & - & - \\
\hline $7 / 24 / 00$ & 33.1 & 21.4 & 50.6 & 18.0 & - & 12.1 & 58.1 & 8.5 & - & - & - & - \\
\hline $7 / 31 / 00$ & 32.7 & - & 51.3 & 18.7 & - & 12.3 & 59.5 & 8.5 & - & - & - & - \\
\hline $8 / 7 / 00$ & 32.6 & - & 50.9 & 18.8 & - & 12.4 & 58.7 & 8.9 & - & - & - & - \\
\hline $8 / 14 / 00$ & 32.3 & - & 50.2 & 18.6 & - & 12.2 & 53.9 & 8.5 & - & - & - & - \\
\hline $8 / 15 / 00$ & - & 20.7 & - & - & - & - & - & - & - & - & - & - \\
\hline $8 / 21 / 00$ & 32.3 & - & 50.5 & 19.3 & - & 12.1 & 52.3 & 8.0 & - & - & - & - \\
\hline $8 / 28 / 00$ & 32.4 & - & 50.2 & 19.2 & - & 12.3 & 58.2 & - & - & - & - & - \\
\hline 9/6/00 & 32.9 & - & 49.0 & 19.4 & - & 11.7 & 55.1 & - & - & - & - & - \\
\hline 9/18/00 & 32.0 & 20.9 & 51.0 & 20.0 & - & 12.7 & 59.2 & - & - & - & - & - \\
\hline $9 / 25 / 00$ & 32.6 & - & 51.0 & 19.4 & - & 12.7 & 60.1 & - & - & - & - & - \\
\hline $10 / 1 / 00$ & - & 20.8 & - & - & - & - & - & - & - & - & - & - \\
\hline $10 / 2 / 00$ & 33.1 & - & 51.2 & 19.2 & - & 12.7 & 60.2 & - & - & - & - & - \\
\hline $10 / 9 / 00$ & 33.6 & - & 51.0 & 19.8 & - & 12.9 & 60.6 & - & - & - & - & - \\
\hline $10 / 16 / 00$ & 30.9 & 19.1 & 45.2 & 18.3 & - & 12.3 & 50.6 & - & - & - & - & - \\
\hline $10 / 18 / 00$ & - & - & - & - & - & - & - & - & - & - & - & - \\
\hline $11 / 1 / 00$ & - & - & - & 21.5 & - & - & - & 9.2 & - & - & - & - \\
\hline $11 / 6 / 00$ & 32.8 & - & 50.6 & 19.3 & - & 12.9 & 60.5 & 8.8 & - & - & - & - \\
\hline $11 / 13 / 00$ & 34.7 & - & 52.1 & 22.0 & - & 13.6 & 62.6 & 9.3 & - & - & - & - \\
\hline $11 / 20 / 00$ & - & - & - & 21.4 & - & - & - & 9.6 & - & - & - & - \\
\hline $11 / 27 / 00$ & 33.0 & - & 50.6 & 21.5 & - & 13.2 & - & 8.8 & - & - & - & - \\
\hline $12 / 4 / 00$ & 34.0 & - & 53.8 & 21.5 & - & 22.4 & - & 9.3 & - & - & - & - \\
\hline $12 / 11 / 00$ & 31.4 & - & 49.8 & 19.6 & - & - & 58.0 & 8.3 & - & - & - & - \\
\hline $12 / 18 / 00$ & 29.8 & 20.5 & 49.6 & 19.7 & - & 12.8 & - & 8.3 & - & - & - & - \\
\hline
\end{tabular}


Table 4. Nitrate concentrations, in milligrams per liter as $\mathrm{NO}_{3}$, in ground water from wells in Warren ground-water basin, San Bernardino County, California, 1964-2001—Continued

\begin{tabular}{|c|c|c|c|c|c|c|c|c|c|c|c|c|}
\hline $\begin{array}{c}1 N / 5 E- \\
3402 \\
(9 W)\end{array}$ & $\begin{array}{c}\text { 1N/5E- } \\
34 \mathrm{P4} \\
(10 \mathrm{~W})\end{array}$ & $\begin{array}{c}1 \mathrm{~N} / 5 \mathrm{E}- \\
35 \mathrm{~K} 1 \\
(11 \mathrm{~W})\end{array}$ & $\begin{array}{c}1 N / 5 E- \\
34 N 1 \\
(5 W)\end{array}$ & $\begin{array}{c}1 \mathrm{~N} / 6 \mathrm{E}- \\
29 \mathrm{J3} \\
(11 \mathrm{E})\end{array}$ & $\begin{array}{c}1 \mathrm{~N} / 6 \mathrm{E}- \\
29 \mathrm{R} 3 \\
(13 \mathrm{E})\end{array}$ & $\begin{array}{c}\text { 1N/5E- } \\
36 G 1 \\
\text { (YV1-570) }\end{array}$ & $\begin{array}{c}\text { 1N/5E- } \\
36 G 2 \\
\text { (YV1-400) }\end{array}$ & $\begin{array}{c}\text { 1N/5E- } \\
36 G 3 \\
\text { (YV1-305) }\end{array}$ & $\begin{array}{c}\text { 1N/5E- } \\
36 G 4 \\
\text { (YV1-230) }\end{array}$ & $\begin{array}{c}\text { 1N/5E- } \\
36 \mathrm{M} 1 \\
\text { (YV2-570) }\end{array}$ & $\begin{array}{c}\text { 1N/5E- } \\
36 \mathrm{M} 2 \\
\text { (YV2-390) }\end{array}$ & $\begin{array}{c}\text { 1N/5E- } \\
36 \mathrm{M} 3 \\
(\mathrm{YV} 2-300)\end{array}$ \\
\hline West & West & West & West & Northeast & Northeast & Mideast & Mideast & Mideast & Mideast & Midwest & Midwest & Midwest \\
\hline- & - & - & - & - & - & - & - & - & - & - & - & - \\
\hline- & - & - & - & - & - & - & - & - & - & - & - & - \\
\hline- & - & - & - & - & - & - & - & - & - & - & - & - \\
\hline- & - & 24.8 & - & - & - & - & - & - & - & - & - & - \\
\hline- & 5.9 & - & - & - & - & - & - & - & - & - & - & - \\
\hline 9.7 & - & - & - & - & - & - & - & - & - & - & - & - \\
\hline- & - & 24.9 & - & - & - & - & - & - & - & - & - & - \\
\hline- & - & 25.3 & - & - & - & - & - & - & - & - & - & - \\
\hline- & - & 23.9 & - & - & - & - & - & - & - & - & - & - \\
\hline- & - & 22.6 & - & - & - & - & - & - & - & - & - & - \\
\hline- & - & 24.2 & - & - & - & - & - & - & - & - & - & - \\
\hline- & - & 24.8 & - & - & - & - & - & - & - & - & - & - \\
\hline- & - & - & - & - & - & - & - & - & - & - & - & - \\
\hline- & - & - & - & - & - & - & - & - & - & - & - & - \\
\hline- & - & 24.9 & - & - & - & - & - & - & - & - & - & - \\
\hline- & - & 24.1 & - & - & - & - & - & - & - & - & - & - \\
\hline- & - & 24.1 & - & - & - & - & - & - & - & - & - & - \\
\hline- & - & - & - & - & - & - & - & - & - & - & - & - \\
\hline- & - & 23.1 & - & - & - & - & - & - & - & - & - & - \\
\hline- & - & 22.6 & - & - & - & - & - & - & - & - & - & - \\
\hline- & - & 22.0 & - & - & - & - & - & - & - & - & - & - \\
\hline 11.8 & - & - & - & - & - & - & - & - & - & - & - & - \\
\hline- & - & 23.0 & - & - & - & - & - & - & - & - & - & - \\
\hline- & - & 22.3 & - & - & - & - & - & - & - & - & - & - \\
\hline- & - & 22.4 & - & - & - & - & - & - & - & - & - & - \\
\hline- & - & 22.4 & - & - & - & - & - & - & - & - & - & - \\
\hline- & - & 21.6 & - & - & - & - & - & - & - & - & - & - \\
\hline- & - & - & - & - & - & - & - & - & - & - & - & - \\
\hline- & - & 21.1 & - & - & - & - & - & - & - & - & - & - \\
\hline- & - & 21.2 & - & - & - & - & - & - & - & - & - & - \\
\hline- & - & 20.8 & - & - & - & - & - & - & - & - & - & - \\
\hline- & - & 21.8 & - & - & - & - & - & - & - & - & - & - \\
\hline- & - & 21.2 & - & - & - & - & - & - & - & - & - & - \\
\hline- & - & - & - & - & - & - & - & - & - & - & - & - \\
\hline- & - & 20.8 & - & - & - & - & - & - & - & - & - & - \\
\hline- & - & 20.7 & - & - & - & - & - & - & - & - & - & - \\
\hline- & - & 19.3 & - & - & - & - & - & - & - & - & - & - \\
\hline- & 6.7 & - & - & - & - & - & - & - & - & - & - & - \\
\hline- & - & 21.7 & - & - & - & - & - & - & - & - & - & - \\
\hline- & - & - & - & - & - & - & - & - & - & - & - & - \\
\hline- & - & - & - & - & - & - & - & - & - & - & - & - \\
\hline- & - & - & - & - & - & - & - & - & - & - & - & - \\
\hline- & - & - & - & - & - & - & - & - & - & - & - & - \\
\hline- & - & 20.3 & - & - & - & - & - & - & - & - & - & - \\
\hline- & - & 18.8 & - & - & - & - & - & - & - & - & - & - \\
\hline- & - & - & - & - & - & - & - & - & - & - & - & - \\
\hline
\end{tabular}


Table 4. Nitrate concentrations, in milligrams per liter as $\mathrm{NO}_{3}$, in ground water from wells in Warren ground-water basin, San Bernardino County, California, 1964-2001—Continued

\begin{tabular}{|c|c|c|c|c|c|c|c|c|c|c|c|c|}
\hline Date & $\begin{array}{c}\text { 1N/5E- } \\
36 \mathrm{~L} 1 \\
\text { (7E) }\end{array}$ & $\begin{array}{c}\text { 1N/5E- } \\
36 K 3 \\
(14 E)\end{array}$ & $\begin{array}{c}1 \mathrm{~N} / 5 \mathrm{E}- \\
36 \mathrm{M} 4 \\
(12 \mathrm{E})\end{array}$ & $\begin{array}{c}1 \mathrm{~N} / 6 \mathrm{E}- \\
31 \mathrm{C1} \\
(5 \mathrm{E})\end{array}$ & $\begin{array}{c}\text { 1N/5E- } \\
36 K 2 \\
(9 E)\end{array}$ & $\begin{array}{c}\text { 1N/5E- } \\
36 \mathrm{M} 5 \\
\text { (16E) }\end{array}$ & $\begin{array}{c}\text { 1N/5E- } \\
36 \mathrm{M6} \\
\text { (17E) }\end{array}$ & $\begin{array}{c}\text { 1N/5E- } \\
36 \mathrm{H} 2 \\
(18 \mathrm{E})\end{array}$ & $\begin{array}{c}1 \mathrm{~N} / 5 \mathrm{E} \\
34 \mathrm{~K} 2 \\
(2 \mathrm{~W})\end{array}$ & $\begin{array}{c}\text { 1N/5E- } \\
35 P 1 \\
(3 W)\end{array}$ & $\begin{array}{c}1 N / 5 E- \\
3401 \\
(6 W)\end{array}$ & $\begin{array}{c}\text { 1S/5E- } \\
\text { 3D1 } \\
(8 W)\end{array}$ \\
\hline [Hydrogeologic units] & Midwest & Mideast & Midwest & Northeast & Midwest & Midwest & Midwest & Mideast & West & West & West & West \\
\hline $12 / 27 / 00$ & - & - & - & 20.2 & - & - & - & 8.3 & - & - & - & - \\
\hline $1 / 8 / 01$ & 30.0 & - & 50.0 & 20.0 & - & - & - & 8.5 & - & - & - & - \\
\hline $1 / 15 / 01$ & - & 21.0 & 51.0 & 21.0 & - & 13.0 & - & 8.5 & - & - & 11.0 & - \\
\hline $1 / 17 / 01$ & - & - & - & - & - & - & - & - & - & 22.0 & - & - \\
\hline $1 / 22 / 01$ & - & - & - & 21.0 & - & - & - & 8.7 & - & - & - & - \\
\hline $1 / 29 / 01$ & 28.0 & - & 51.0 & 21.0 & - & - & - & 8.5 & - & - & - & - \\
\hline $2 / 5 / 01$ & 27.0 & - & 52.0 & 20.0 & - & 13.0 & - & 5.1 & - & - & - & - \\
\hline $2 / 12 / 01$ & 28.0 & - & - & 21.0 & - & - & - & 8.6 & - & - & - & - \\
\hline $2 / 21 / 01$ & - & 21.0 & - & 21.0 & - & - & - & 8.5 & - & - & - & - \\
\hline $2 / 28 / 01$ & 28.0 & - & - & 21.0 & - & - & - & 8.7 & - & - & - & - \\
\hline $3 / 5 / 01$ & 26.0 & - & - & 21.0 & - & - & - & 8.5 & - & - & - & - \\
\hline $3 / 12 / 01$ & 26.0 & - & - & 20.0 & - & - & - & 8.4 & - & - & - & - \\
\hline $3 / 19 / 01$ & 26.0 & 21.0 & - & 21.0 & - & 13.0 & - & 8.4 & - & - & - & - \\
\hline $3 / 26 / 01$ & - & - & - & 22.0 & - & - & - & 8.7 & - & - & - & - \\
\hline $4 / 2 / 01$ & 27.0 & - & - & 22.0 & - & - & - & - & - & - & - & - \\
\hline $4 / 11 / 01$ & 27.0 & - & - & 23.0 & - & - & - & 9.0 & - & - & - & 9.7 \\
\hline $4 / 16 / 01$ & 27.0 & 22.0 & - & - & - & 14.0 & - & - & - & - & - & - \\
\hline $4 / 23 / 01$ & 27.0 & - & - & 22.0 & - & - & - & 8.9 & - & - & - & - \\
\hline $5 / 2 / 01$ & 25.0 & 21.0 & - & 22.0 & - & 14.0 & - & 8.7 & - & - & - & - \\
\hline $5 / 7 / 01$ & 27.0 & - & - & 23.0 & - & - & - & 8.8 & - & - & - & - \\
\hline $5 / 14 / 01$ & - & - & - & 22.0 & - & - & - & - & - & - & - & - \\
\hline $5 / 16 / 01$ & 26.0 & - & - & - & - & - & - & - & - & - & - & - \\
\hline $5 / 21 / 01$ & 27.0 & - & - & 24.0 & - & - & - & 8.9 & - & - & - & - \\
\hline $5 / 22 / 01$ & - & - & - & - & - & 13.0 & - & - & - & - & - & - \\
\hline $5 / 30 / 01$ & 27.0 & - & - & 24.0 & - & - & - & - & - & - & - & - \\
\hline $6 / 4 / 01$ & - & - & - & 23.0 & - & - & - & 8.4 & - & - & - & - \\
\hline $6 / 11 / 01$ & 29.0 & - & - & 27.0 & - & 16.0 & - & 9.8 & - & - & - & - \\
\hline $6 / 18 / 01$ & 26.0 & 21.0 & - & 24.0 & - & 15.0 & - & 8.9 & - & - & - & - \\
\hline $6 / 27 / 01$ & - & - & - & 25.0 & - & 15.0 & - & 9.2 & - & - & - & - \\
\hline $7 / 2 / 01$ & 25.0 & 21.0 & - & 25.0 & - & 14.0 & 52.0 & 8.6 & - & - & - & - \\
\hline $7 / 9 / 01$ & 26.0 & - & - & 25.0 & - & 15.0 & - & 8.7 & - & - & - & - \\
\hline 7/10/01 & 26.0 & 19.0 & - & - & - & - & 52.0 & - & 12.0 & - & - & - \\
\hline 7/10/01 & $* 25.2$ & - & - & - & - & - & $* 54.9$ & - & $* 13.8$ & $* 22.0$ & $* 11.0$ & - \\
\hline $7 / 11 / 01$ & - & $* 20.7$ & - & - & - & - & - & - & - & - & - & - \\
\hline $7 / 16 / 01$ & 26.0 & - & - & 26.0 & - & 16.0 & 56.0 & 9.1 & - & - & - & - \\
\hline 7/30/01 & 25.0 & - & - & - & - & 15.0 & - & - & - & - & - & - \\
\hline 8/7/01 & - & 17.0 & - & 31.0 & - & 15.0 & - & 8.6 & - & - & - & - \\
\hline $8 / 27 / 01$ & - & - & - & - & - & - & - & - & - & - & - & $* 9.8$ \\
\hline $8 / 28 / 01$ & - & - & - & - & - & - & - & - & - & - & - & - \\
\hline $8 / 29 / 01$ & - & - & - & - & - & - & - & - & - & - & - & - \\
\hline
\end{tabular}


Table 4. Nitrate concentrations, in milligrams per liter as $\mathrm{NO}_{3}$, in ground water from wells in Warren ground-water basin, San Bernardino County, California, 1964-2001—Continued

\begin{tabular}{|c|c|c|c|c|c|c|c|c|c|c|c|c|}
\hline $\begin{array}{c}1 N / 5 E- \\
3402 \\
(9 W)\end{array}$ & $\begin{array}{c}1 \mathrm{~N} / 5 \mathrm{E}- \\
34 \mathrm{P4} \\
(10 \mathrm{~W})\end{array}$ & $\begin{array}{c}1 \mathrm{~N} / 5 \mathrm{E}- \\
35 \mathrm{~K} 1 \\
(11 \mathrm{~W})\end{array}$ & $\begin{array}{c}\text { 1N/5E- } \\
34 N 1 \\
(5 W)\end{array}$ & $\begin{array}{c}1 \mathrm{~N} / 6 \mathrm{E}- \\
29 \mathrm{~J} 3 \\
(11 \mathrm{E})\end{array}$ & $\begin{array}{c}1 N / 6 E- \\
29 R 3 \\
(13 E)\end{array}$ & $\begin{array}{c}\text { 1N/5E- } \\
36 G 1 \\
\text { (YV1-570) }\end{array}$ & $\begin{array}{c}\text { 1N/5E- } \\
36 G 2 \\
\text { (YV1-400) }\end{array}$ & $\begin{array}{c}\text { 1N/5E- } \\
36 G 3 \\
\text { (YV1-305) }\end{array}$ & $\begin{array}{c}\text { 1N/5E- } \\
36 G 4 \\
\text { (YV1-230) }\end{array}$ & $\begin{array}{c}\text { 1N/5E- } \\
\text { 36M1 } \\
\text { (YV2-570) }\end{array}$ & $\begin{array}{c}\text { 1N/5E- } \\
36 M 2 \\
\text { (YV2-390) }\end{array}$ & $\begin{array}{c}\text { 1N/5E- } \\
36 M 3 \\
\text { (YV2-300) }\end{array}$ \\
\hline West & West & West & West & Northeast & Northeast & Mideast & Mideast & Mideast & Mideast & Midwest & Midwest & Midwest \\
\hline- & - & - & - & - & - & - & - & - & - & - & - & - \\
\hline- & - & - & - & - & - & - & - & - & - & - & - & - \\
\hline- & - & - & - & - & - & - & - & - & - & - & - & - \\
\hline 13.0 & - & - & - & - & - & - & - & - & - & - & - & - \\
\hline- & - & - & - & - & - & - & - & - & - & - & - & - \\
\hline- & - & 19.0 & - & - & - & - & - & - & - & - & - & - \\
\hline- & - & - & - & - & - & - & - & - & - & - & - & - \\
\hline- & - & - & - & - & - & - & - & - & - & - & - & - \\
\hline- & - & - & - & - & - & - & - & - & - & - & - & - \\
\hline- & - & - & - & - & - & - & - & - & - & - & - & - \\
\hline- & - & - & - & - & - & - & - & - & - & - & - & - \\
\hline- & - & 18.0 & - & - & - & - & - & - & - & - & - & - \\
\hline- & - & - & - & - & - & - & - & - & - & - & - & - \\
\hline- & - & - & - & - & - & - & - & - & - & - & - & - \\
\hline- & - & - & - & - & - & - & - & - & - & - & - & - \\
\hline- & 11.0 & 19.0 & - & - & - & - & - & - & - & - & - & - \\
\hline- & - & - & - & - & - & - & - & - & - & - & - & - \\
\hline- & - & - & - & - & - & - & - & - & - & - & - & - \\
\hline- & - & 19.0 & - & - & - & - & - & - & - & - & - & - \\
\hline- & - & 19.0 & - & - & - & - & - & - & - & - & - & - \\
\hline- & - & 18.0 & - & - & - & - & - & - & - & - & - & - \\
\hline- & - & - & - & - & - & - & - & - & - & - & - & - \\
\hline- & - & - & - & - & - & - & - & - & - & - & - & - \\
\hline- & - & - & - & - & - & - & - & - & - & - & - & - \\
\hline- & - & 19.0 & - & - & - & - & - & - & - & - & - & - \\
\hline- & - & 18.0 & - & - & - & - & - & - & - & - & - & - \\
\hline- & - & 21.0 & - & - & - & - & - & - & - & - & - & - \\
\hline- & - & 14.0 & - & - & - & - & - & - & - & - & - & - \\
\hline- & - & - & - & - & - & - & - & - & - & - & - & - \\
\hline- & - & 17.0 & - & - & - & - & - & - & - & - & - & - \\
\hline- & - & 18.0 & - & - & - & - & - & - & - & - & - & - \\
\hline- & - & - & - & - & - & - & - & - & - & - & - & - \\
\hline$* 13.0$ & - & - & - & - & - & - & - & - & - & - & - & - \\
\hline- & - & - & - & - & - & - & - & - & - & - & - & - \\
\hline- & - & - & - & - & - & - & - & - & - & - & - & - \\
\hline- & - & 18.0 & - & - & - & - & - & - & - & - & - & - \\
\hline- & - & 17.0 & - & - & - & - & - & - & - & - & - & - \\
\hline- & - & - & - & - & - & - & *76.6.0 & - & - & - & - & - \\
\hline- & - & - & - & - & - & $* 9.4$ & - & $* 35.0$ & $* 14.4$ & - & - & - \\
\hline- & - & - & - & - & - & - & - & - & - & *82.0 & $* 20.8$ & *3.6 \\
\hline
\end{tabular}

